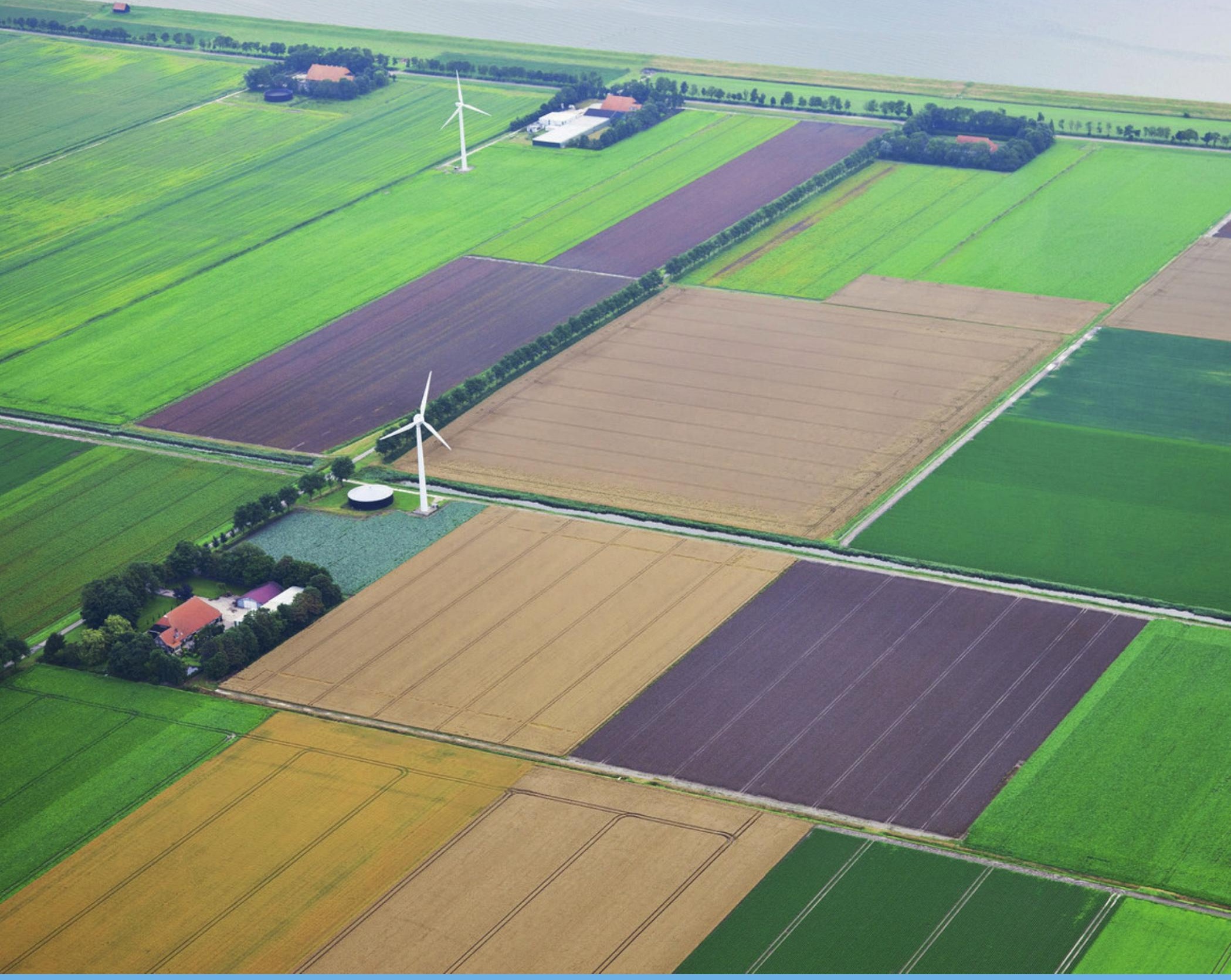

\title{
Analyse van de landbouw en het landelijk gebied in Nederland: een SWOT-analyse
}

Bijlagen

Petra Berkhout, Annemiek Eweg, Allard Jellema, Harold van der Meulen, Gabe Venema 



\section{Analyse van de landbouw en het landelijk gebied in Nederland: een SWOT-analyse}

Bijlagen

Petra Berkhout, Annemiek Eweg, Allard Jellema, Harold van der Meulen, Gabe Venema

Dit onderzoek is uitgevoerd door Wageningen Economic Research en gesubsidieerd door het ministerie van Landbouw, Natuur en Voedselkwaliteit, in het kader van het Beleidsondersteunend onderzoeksthema Economie (BO-43-115-021)

Wageningen Economic Research

Wageningen, juni 2021

RAPPORT

2021-075

ISBN 978-94-6395-868-4 
Petra Berkhout, Annemiek Eweg, Allard Jellema, Harold van der Meulen, Gabe Venema, 2021. Analyse van de landbouw en het landelijk gebied in Nederland: een SWOT-analyse; Bijlagen. Wageningen, Wageningen Economic Research, Rapport 2021-075. 160 blz.

Trefwoorden: GLB, Gemeenschappelijk Landbouwbeleid, SWOT, NSP, Nationaal Strategisch Plan

Dit rapport is gratis te downloaden op https://doi.org/10.18174/549224 of op www.wur.nl/economicresearch (onder Wageningen Economic Research publicaties).

(C) 2021 Wageningen Economic Research

Postbus 29703, 2502 LS Den Haag, T 07033583 30, E communications.ssg@wur.nl, www.wur.nl/economic-research. Wageningen Economic Research is onderdeel van Wageningen University \& Research.

\section{(cc) BY-NC}

Dit werk valt onder een Creative Commons Naamsvermelding-Niet Commercieel 4.0 Internationaallicentie.

(C) Wageningen Economic Research, onderdeel van Stichting Wageningen Research, 2021

De gebruiker mag het werk kopiëren, verspreiden en doorgeven en afgeleide werken maken. Materiaal van derden waarvan in het werk gebruik is gemaakt en waarop intellectuele eigendomsrechten berusten, mogen niet zonder voorafgaande toestemming van derden gebruikt worden. De gebruiker dient bij het werk de door de maker of de licentiegever aangegeven naam te vermelden, maar niet zodanig dat de indruk gewekt wordt dat zij daarmee instemmen met het werk van de gebruiker of het gebruik van het werk. De gebruiker mag het werk niet voor commerciële doeleinden gebruiken.

Wageningen Economic Research aanvaardt geen aansprakelijkheid voor eventuele schade voortvloeiend uit het gebruik van de resultaten van dit onderzoek of de toepassing van de adviezen.

Wageningen Economic Research is ISO 9001:2015 gecertificeerd.

Wageningen Economic Research Rapport 2021-075 | Projectcode 2282500441

Foto omslag: Shutterstock 


\section{Inhoud}

$\begin{array}{ll}\text { Toelichting } & 7\end{array}$

$\begin{array}{lll}1.1 & \text { Algemene beschrijving van de sector akkerbouw } & 8\end{array}$

$\begin{array}{lll}1.2 & \text { SWOT-analyse per specifieke doelstelling } & 13\end{array}$

(a) Bieden van steun met het oog op een leefbaar landbouwinkomen en veerkracht in de hele Unie om de voedselzekerheid te vergroten;

(b) Vergroten van de marktgerichtheid en van het concurrentievermogen, onder meer door beter te focussen op onderzoek, technologie en digitalisering;

(c) Verbeteren van de positie van de landbouwers in de waardeketen;

(d) Bijdragen tot matiging van en aanpassing aan klimaatverandering en tot duurzame energie;

(e) Bevorderen van duurzame ontwikkeling en efficiënt beheer van natuurlijke hulpbronnen zoals water, bodem en lucht;

(f) Bijdragen tot de bescherming van de biodiversiteit, versterken van ecosysteemdiensten en in stand houden van habitats en landschappen.

$\begin{array}{lll}1.4 & \text { Bijlage Indicatoren } & 31\end{array}$

2.1 Algemene beschrijving van de sector melkvee

2.2 WOT-analyse per deelsector en per specifieke doelstelling (vergelijk H3 van de Houtskool SWOT)

(a) Bieden van steun met het oog op een leefbaar landbouwinkomen en veerkracht in de hele Unie om de voedselzekerheid te vergroten;

(b) Vergroten van de marktgerichtheid en van het concurrentievermogen, onder meer door beter te focussen op onderzoek, technologie en digitalisering;

(c) Verbeteren van de positie van de landbouwers in de waardeketen;

(d) Bijdragen tot matiging van en aanpassing aan klimaatverandering en tot duurzame energie;

(e) Bevorderen van duurzame ontwikkeling en efficiënt beheer van natuurlijke hulpbronnen zoals water, bodem en lucht;

(f) Bijdragen tot de bescherming van de biodiversiteit, versterken van ecosysteemdiensten en in stand houden van habitats en landschappen.

$\begin{array}{lll}2.4 & \text { Bijlage Indicatoren } & 51\end{array}$

3.1 Algemene beschrijving van de sector glasgroente $\quad 56$

3.2 SWOT-analyse per specifieke doelstelling 59

(a) Bieden van steun met het oog op een leefbaar landbouwinkomen en veerkracht in de hele Unie om de voedselzekerheid te vergroten; 
(b) Vergroten van de marktgerichtheid en van het concurrentievermogen, onder meer door beter te focussen op onderzoek, technologie en digitalisering;

(c) Verbeteren van de positie van de landbouwers in de waardeketen;

(d) Bijdragen tot matiging van en aanpassing aan klimaatverandering en tot duurzame energie;

(e) Bevorderen van duurzame ontwikkeling en efficiënt beheer van natuurlijke hulpbronnen zoals water, bodem en lucht;

(f) Bijdragen tot de bescherming van de biodiversiteit, versterken van ecosysteemdiensten en in stand houden van habitats en landschappen.

3.3 Referenties

$\begin{array}{lll}3.4 & \text { Bijlage Indicatoren } & 71\end{array}$

4.1 Algemene beschrijving van de sector vollegrondsgroente $\quad 77$

4.2 SWOT-analyse per specifieke doelstelling $\quad 81$

(a) Bieden van steun met het oog op een leefbaar landbouwinkomen en veerkracht in de hele Unie om de voedselzekerheid te vergroten;

(b) Vergroten van de marktgerichtheid en van het concurrentievermogen, onder meer door beter te focussen op onderzoek, technologie en digitalisering;

(c) Verbeteren van de positie van de landbouwers in de waardeketen;

(d) Bijdragen tot matiging van en aanpassing aan klimaatverandering en tot duurzame energie;

(e) Bevorderen van duurzame ontwikkeling en efficiënt beheer van natuurlijke hulpbronnen zoals water, bodem en lucht;

(f) Bijdragen tot de bescherming van de biodiversiteit, versterken van ecosysteemdiensten en in stand houden van habitats en landschappen.

4.3 Referenties

4.4 Bijlage Indicatoren

5.1 Algemene beschrijving van de sector snijbloemen

5.2 SWOT-analyse per specifieke doelstelling

(a) Bieden van steun met het oog op een leefbaar landbouwinkomen en veerkracht in de hele Unie om de voedselzekerheid te vergroten;

(b) Vergroten van de marktgerichtheid en van het concurrentievermogen, onder meer door beter te focussen op onderzoek, technologie en digitalisering;

(c) Verbeteren van de positie van de landbouwers in de waardeketen;

(d) Bijdragen tot matiging van en aanpassing aan klimaatverandering en tot duurzame energie;

(e) Bevorderen van duurzame ontwikkeling en efficiënt beheer van natuurlijke hulpbronnen zoals water, bodem en lucht;

(f) Bijdragen tot de bescherming van de biodiversiteit, versterken van ecosysteemdiensten en in stand houden van habitats en landschappen.

5.4 Bijlage Indicatoren 
6.1 Algemene beschrijving van de varkenshouderij $\quad 121$

6.2 SWOT-analyse per specifieke doelstelling 126

(a) Bieden van steun met het oog op een leefbaar landbouwinkomen en veerkracht in de hele Unie om de voedselzekerheid te vergroten;

(b) Vergroten van de marktgerichtheid en van het concurrentievermogen, onder meer door beter te focussen op onderzoek, technologie en digitalisering;

(c) Verbeteren van de positie van de landbouwers in de waardeketen;

(d) Bijdragen aan mitigatie en adaptatie aan klimaatverandering en leveren van een bijdrage aan een duurzame energieproductie;

(e) Bevorderen van duurzame ontwikkeling en efficiënt beheer van natuurlijke hulpbronnen, zoals water, bodem en lucht;

(f) Bijdragen tot de bescherming van de biodiversiteit, versterken van ecosysteemdiensten en in stand houden van Habitats en landschappen.

6.3 Referenties

6.4 Bijlage Indicatoren

7.1 Algemene beschrijving van de vleeskuikenhouderij

(a) Bieden van steun met het oog op een leefbaar landbouwinkomen en veerkracht in de hele Unie om de voedselzekerheid te vergroten;

(b) Vergroten van de marktgerichtheid en van het concurrentievermogen, onder meer door beter te focussen op onderzoek, technologie en digitalisering;

(c) Verbeteren van de positie van de landbouwers in de waardeketen;

(d) Bijdragen tot matiging van en aanpassing aan klimaatverandering

(e) Bevorderen van duurzame ontwikkeling en efficiënt beheer van natuurlijke hulpbronnen zoals water, bodem en lucht;

(f) Bijdragen tot de bescherming van de biodiversiteit, versterken van ecosysteemdiensten en in stand houden van Habitats en landschappen. 



\section{Toelichting}

In 2019 is een Houtskool-SWOT opgesteld op het niveau van de gehele landbouwsector. Naar aanleiding van de besprekingen in Brussel tussen Commissie en Raad, zijn in 2020 aanvullende analyses uitgevoerd voor de thema's water, jonge boeren, voedsel en dierenwelzijn en regionale differentiatie. Voor 2020 waren ook aanvullende SWOT-analyses naar deelsector binnen de agrosector voorzien, maar deze moesten worden uitgesteld. De inzet van sectorexperts ten behoeve van onderzoek in verband met de corona-epidemie, heeft ertoe geleid dat deze sectorale analyses in het eerste kwartaal van 2021 zijn uitgevoerd.

In deze annex is deze aanvullende sectorale SWOT-analyse opgenomen. De analyse is niet voor alle onderscheiden deelsectoren van de landbouwsector opgesteld. De volgende deelsectoren zijn meegenomen:

- Glasgroente - niet paddestoelen

- Melkveehouderij - melkveehouderij, niet geiten, kalverhouderij, vleesvee

- Akkerbouw

- Varkenshouderij - zeugenhouderij en vleesvarkenshouderij

- Pluimveehouderij - vleeskuikenhouderij, niet kalkoenen en eenden

- Sierteelt - snijbloemen, niet bloembollen en pot/perkplanten

- Opengrondstuinbouw - vollegrondsgroente, niet fruitteelt en boomkwekerij.

Deze sectorale SWOT-analyses moeten worden gelezen in samenhang met de definitieve SWOTanalyse. De sectorale analyses gaan namelijk uit van de definitieve SWOT en verbijzonderen deze waar nodig naar de deelsector in kwestie. De analyse is daarbij beperkt tot de eerste zes subdoelstellingen van het GLB ( $a$ tot en met $\mathrm{f}$ ), omdat een verbijzondering voor subdoelstellingen $\mathrm{g}, \mathrm{h}$ en i niet relevant is.

De analyse begint met een algemene beschrijving van de deelsector in kwestie, op basis van de door de EC voorgeschreven contextindicatoren die ook in de definitieve SWOT zijn gebruikt. Deze contextindicatoren zijn toegespitst - indien data beschikbaar zijn - op de deelsector in kwestie. Vervolgens is per subdoelstelling een SWOT-analyse opgesteld volgens het stramien dat ook is gevolgd in de definitieve SWOT.

In de deelanalyses wordt overwegend ingegaan op de specifieke punten die relevant zijn voor de deelsector. Indien de analyse voor de deelsector niet anders is dan voor de totale landbouwsector, wordt deze niet herhaald. Per assenkruis is aangegeven of er toevoegingen zijn (deze zijn cursief aangegeven) dan wel of onderwerpen niet van toepassing zijn (dit is in de toelichtende tekst aangegeven). 


\section{SWOT-analyse deelsector akkerbouw}

Bert Smit

N.B. deze analyse moet worden gelezen in samenhang met de swOT-analyse op het niveau van de landbouw als geheel. Onderhavige analyse verbijzondert de SWOT-analyse waar nodig naar de deelsector in kwestie.

\subsection{Algemene beschrijving van de sector akkerbouw}

Korte beschrijving van de sector ${ }^{1}$

De akkerbouw bestaat uit de teelt van granen, wortel- en knolgewassen, peulvruchten, handelsgewassen en groenten. De teelt van granen, aardappelen en suikerbieten is al eeuwenlang onderdeel van de Nederlandse landbouw en voedselvoorziening. In het verre verleden werden deze gewassen vooral voor eigen gebruik geteeld. Met de opkomst van de moderne landbouwtechnieken (onder andere mechanisatie (tractor), kunstmest, gewasbescherming, veredeling en kennis) na de tweede wereldoorlog is de productie fors toegenomen. Dit zette aan tot het zoeken naar mogelijkheden om de houdbaarheid van producten te verlengen door ze te bewaren en/of op een andere manier te verwaarden (onder andere conserveren, invriezen). Moderne bewaarplaatsen, goede logistiek én efficiënte industriële verwerking van de producten bieden de mogelijkheid om producten te verduurzamen en wereldwijd te exporteren.

Het akkerbouwcomplex omvat het geheel van de productie en verwerking van akkerbouwproducten. Kenmerkend voor de Nederlandse akkerbouwsector is dat de plantaardige productie grondgebonden, grootschalig, vergaand gemechaniseerd en daarmee steeds kapitaalintensiever is geworden. Onder invloed van hoge grondprijzen en vergrijzing zullen eigendom en exploitatie van landbouwgrond steeds meer van elkaar gescheiden zijn. Akkerbouwbedrijven hebben ongeveer de helft van hun cultuurgrond in eigendom en de andere helft wordt gepacht (Agrimatie.nl). Voor de verwerking zijn in Nederland diverse grotere particuliere of coöperatieve bedrijven gevestigd of hebben vestigingen in Nederland zoals Cosun (met als belangrijkste dochters Cosun Beet Company en Aviko), Avebe, Agrifirm, Farm Frites, McCain, Lamb Weston Meijer en HAK. Naast deze grotere bedrijven is er nog een groot aantal kleinere handels- en verwerkingsbedrijven. Een groot deel van de producten wordt geëxporteerd.

\section{Productiesysteem ${ }^{1}$}

Kenmerkend voor de akkerbouw is dat alle gewassen in de open grond worden geteeld (vollegrondsteelt). Teelt en verwerking zijn vergaand gemechaniseerd. Toepassing van nieuwe technologieën (onder andere informatie/monitoring/data, detectie, plaatsbepaling) binnen de veredeling, teelt en verwerking speelt een belangrijke rol. Duurzaamheid vormt in alle productiesystemen een belangrijk, voortdurend aandachtspunt waarbij gezonde en veilige producten, transparantie van voedselsystemen, minimale input van meststoffen en gewasbeschermingsmiddelen, energie, plantgezondheid, klimaat, vitale bodem, schoon water, biodiversiteit en reduceren van verspilling door hergebruik centrale elementen vormen. Zowel op het primaire bedrijf als ook in de keten. Er zijn verschillende initiatieven, zoals On the way to PlanetProof, die telers uitdagen en ondersteunen om nog duurzamer te produceren. Deze initiatieven komen vanuit telers zelf, hun sectororganisaties, hun afnemers of komen voort uit maatschappelijke wensen/eisen. Naast de omvangrijke gangbare of traditionele productie is de biologische productie het bekendst.

\footnotetext{
1 Deze tekst is vrijwel volledig afkomstig uit Bremmer et al. (2019), de data zijn geactualiseerd.
} 


\section{Bodem}

Grond is een belangrijke productiefactor voor de akkerbouw. Een vitale bodem is essentieel voor de teelt van gewassen, hun opbrengsten, het inkomen van de agrariër en de voedselvoorziening. Het gebruik van de bodem betekent dat deze onderhouden moet worden. Zo dienen bijvoorbeeld uitputting en structuurbederf van de bodem te worden voorkomen c.q. hersteld. Duurzaam bodemgebruik is sinds 2003 een speerpunt van het nationale bodembeleid. ${ }^{2}$ Het betekent dat de maatschappelijke functie van de bodem, bijvoorbeeld het productievermogen, niet verloren mag gaan. Behoud of verbetering van de bodemstructuur, de bodemgezondheid en de bodemvruchtbaarheid vormen speerpunten voor de akkerbouwer. Dit vraagt om een integrale aanpak die rekening houdt met de bodem-chemische, -fysische en -biologische eigenschappen. Zo werkt het ministerie van LNV in het Nationaal Programma Landbouwbodems (NPL) aan duurzaam bodembeheer. In dit programma wordt samen met de sector gewerkt aan het hoofddoel: alle landbouwbodems in Nederland in 2030 duurzaam beheerd. Daarin worden vier sporen gevolgd: kennis (het ontwikkelen van kennis over duurzaam bodembeheer, dit omzetten naar maatregelen en deze door middel van kennisverspreiding laten landen op het boerenerf), beleid (duurzaam bodembeheer mogelijk maken door beleid stimulerend te laten werken en belemmeringen op te heffen; hierbij gaat het om mestbeleid, pachtbeleid, nieuwe GLB, etc.), agroketen (het wegnemen van negatieve prikkels in de keten) en regio (aansluiten bij bestaande pilots en opstarten van nieuwe regionale initiatieven).

In de PPS Beter Bodembeheer ${ }^{3}$ werken bedrijven, overheid en onderzoek samen aan duurzaam bodembeheer. Diverse maatregelen worden beproefd of al in de praktijk toegepast zoals ruimere gewasrotaties, verbeteren van bemestingsadviezen, gebruik van organische mest, toepassen van de juiste groenbemesters ten behoeve van de organischestofvoorziening, bodemgezondheid en $\mathrm{CO}_{2}$ vastlegging (klimaat), monitoren en beheersen van bodempathogenen (met name aaltjes), gebruik van schone machines om verspreiding van bodempathogenen tegen te gaan, aangepaste machines en werktuigen om de bodembelasting te verminderen zoals het onderzoek naar kleinschalige mechanisatie (SMARAGD) ${ }^{4}$ grondbewerking, precisielandbouw, etc. Deze maatregelen zijn ook gericht op het klimaat, de weerbaarheid van de plant en de bodem en het bevorderen van biodiversiteit. In de PPS Regeneratieve Landbouw wordt gezocht naar bedrijfssystemen waarin niet alleen de negatieve effecten van landbouw worden beperkt, maar juist positieve effecten op met name bodem, biodiversiteit, milieu en klimaat worden nagestreefd.

\section{Aandeel biologisch}

De biologische akkerbouw is een kleine sector. Het aandeel bedrijven met biologische teelt ligt de afgelopen jaren rond de $2 \%$ (tabel C.31). In 2020 werd er op ruim 10.500 ha biologische akkerbouwgewassen geteeld. De akkerbouwgroenten en granen zijn gemeten in hectare de grootste gewasgroepen. ${ }^{5}$ Biologische akkerbouw komt met name in Flevoland veel voor. De bodemvruchtbaarheid is in deze provincie van nature goed en de onkruiddruk laag, twee factoren die de biologische teelt bevorderen en rendabel doen zijn. Ongeveer de helft van de biologische productie in Flevoland wordt geëxporteerd. Dat laat zien dat de binnenlandse vraag achter blijft bij de productie, waarvan verdere uitbreiding door dit feit wordt afgeremd (Dekking et al., 2020).

Op biologische akkerbouwbedrijven worden andere, vaak ruimere rotaties gehanteerd, bijvoorbeeld $1: 6$ in plaats van $1: 4$. In een dergelijk bouwplan komen vaak twee 'rustjaren' voor, die dan bijvoorbeeld ingevuld worden met luzerne of een gras-klavercombinatie. Dit is niet vereist maar wel noodzakelijk om de bodemvruchtbaarheid op peil te houden.

Het areaal biologische akkerbouwgewassen schommelt de laatste jaren tussen de 9.000 en 11.000 ha. De aandelen van de diverse gewasgroepen binnen de biologische akkerbouw zijn vrij constant. Bij de

\footnotetext{
https://www.rivm.nl/duurzaamheid/bodem

3 https://www.beterbodembeheer.nl/nl/beterbodembeheer.htm

4 https://www.wur.nl/nl/project/SMARAGD-Slimme-Mechanisatie-Automatisering-Robotisering-voor-een-AkkerbouwmetGroei-en-Duurzaamheid.htm

5 Het totaal aantal biologische landbouwbedrijven is tussen 2015 en 2020 toegenomen van 1.366 tot 1.826 . In diezelfde periode nam het totaal aantal landbouwbedrijven af van ca 64.000 naar 53.000 (CBS), maar daarvoor waren ook administratieve redenen (zie voetnoot 7). In ieder geval is het relatieve belang van biologische landbouw in aantal bedrijven en oppervlakte toegenomen. In 2018 waren er in Nederland in totaal 241 biologische akkerbouwbedrijven met een totaal areaal van ruim 13.300 ha (Dekking et al., 2020).
} 
biologische akkerbouwgroenten zijn uien en winterpeen veruit de meest geteelde gewassen. Tarwe maakt ongeveer een kwart uit van het totale areaal biologische granen (bij gangbaar is dat circa $70 \%$ ). Andere belangrijke biologische graangewassen zijn gerst, haver, rogge, triticale en overige.

Bedrijfsgrootte, arbeid, opvolging, inkomen

Evenals in de overige sectoren van de landbouw is het aantal akkerbouwbedrijven sinds 2010 gedaald maar wel met een toename in $2015 .{ }^{6}$ De daling is het sterkste bij bedrijven met minder dan 10 ha (zie bijlage 1, tabel C.12). Uitgedrukt in Standaard Opbrengst is alleen het aantal bedrijven met een omzet van meer dan $€ 100.000$ in de afgelopen tien jaar (licht) toegenomen (tabel C.12). Gemiddeld is de gemiddelde oppervlakte met $8 \%$ toegenomen en de omzet (in SO) met $58 \% .^{7}$

Het areaal akkerbouw op gespecialiseerde akkerbouwbedrijven is de afgelopen tien jaar gelijk afgenomen van 390.000 naar ruim 375.000 ha. Tegelijkertijd is de intensiteit, uitgedrukt in percentage van de bedrijven met minimaal $€ 350$ per ha kosten aan meststoffen, veevoer en gewasbeschermingsmiddelen toegenomen van bijna $70 \%$ in 2010 tot $85 \%$ in 2019 (tabel C.33). De toegenomen intensiteit komt ook tot uiting in een hoger gebruik aan gewasbeschermingsmiddelen, namelijk ruim 4.000 ton actieve stof in 2019 tegenover circa 3.850 ton in 2010 en 2015 (tabel C.48). Overigens is de milieubelasting van de gebruikte middelen een betere maat dan het verbruik in $\mathrm{kg}$ actieve stof, omdat de werkzaamheid van middelen per kg actieve stof sterk kan variëren. De milieubelasting zegt meer over het mogelijke vervuilende effect van deze middelen. Deze is in de Nederlandse akkerbouw dalende. 8

\section{Aantal bedrijven, areaal en areaal per bedrijf}

Akkerbouw, totaal

40.000

800.000

36

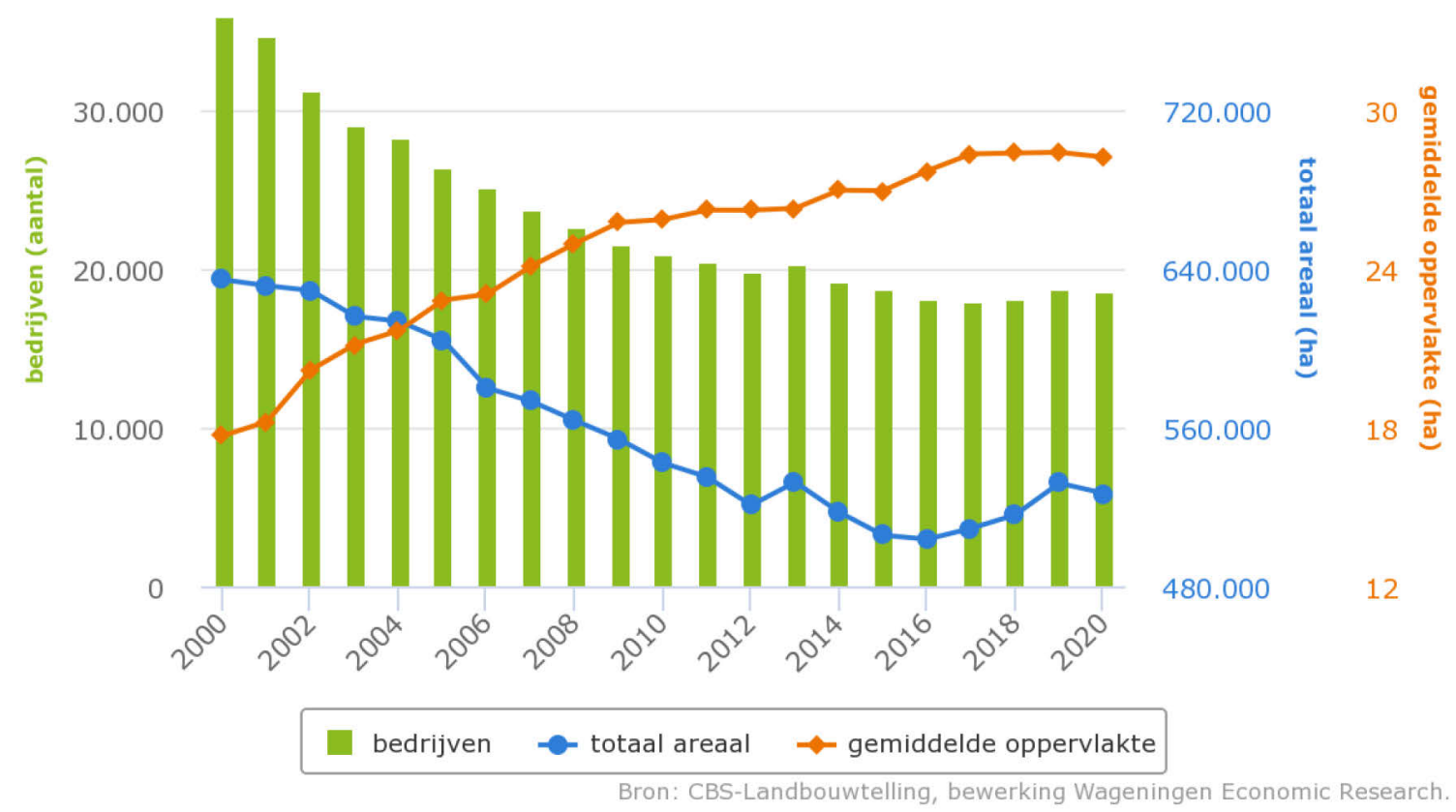

Figuur 1 Aantal bedrijven met akkerbouwgewassen, areaal en areaal per bedrijf. N.B. cijfers kunnen afwijken van in de tekst genoemde, omdat hier alle bedrijven met akkerbouwgewassen worden meegenomen, niet enkel de gespecialiseerde akkerbouwbedrijven

6 Dit heeft te maken met een aangepaste definitie (zie ook toelichting in Smit et al., 2017).

7 Deze sterke toename is toe te schrijven aan twee oorzaken: 1) In 2015/2016 zijn de SO-normen aangepast, met als gevolg een flinke stijging van het aantal SO per bedrijf (+35\%); 2) Vanaf 2016 moeten bedrijven ingeschreven staan bij de KvK om in de Landbouwtelling opgenomen te kunnen worden en om voor GLB-steun in aanmerking te komen. Vele kleine akkerbouwbedrijven zullen dat niet hebben gedaan, met als gevolg een afname $(-13 \%)$ van het aantal bedrijven. Dit laatste leidde tot schaalvergroting van het gemiddelde bedrijf (ook in ha $(+9 \%)$ ).

8 Op Agrimatie zien we de afgelopen jaren een stabilisering van het actievestofgebruik en een daling van de milieubelasting (in milieubelastingspunten ( $\mathrm{mbp})$ ). In zijn algemeenheid is de milieubelasting sterker gedaald dan het actievestofgebruik, wat betekent dat de gebruikte middelen in de loop van de tijd minder schadelijk zijn geworden voor het milieu. 
Het aantal werkzame personen (in aje (arbeidsjaareenheden)) op akkerbouwbedrijven is sinds 2010 toegenomen van bijna 14.500 tot bijna 16.500 aje (ruim 15.600 personen) (tabel C. 13a). Dit aantal betreft de akkerbouwers zelf plus vaste en losse arbeidskrachten. Het aandeel hiervan dat van buiten het gezin afkomstig is, is in die jaren toegenomen van 17 naar $22 \%$ (tabel C. $13 \mathrm{~b}$ ). Dat heeft te maken met de toenemende schaalgrootte en de afnemende beschikbaarheid van gezinsarbeid op het bedrijf.

Het aantal opvolgers ligt met $37 \%$ ongeveer op hetzelfde niveau als in de totale land- en tuinbouw (zie bijlage 1, tabel C.16).

De netto toegevoegde waarde tegen factorkosten (C.24), de beloning voor de inzet van de productiefactoren arbeid, grond en kapitaal, ligt gemiddeld hoger dan in de andere sectoren van de land- en tuinbouw. Na aftrek van de betaalde factorkosten resteert het inkomen voor de ondernemer, dat wil zeggen de beloning van de inzet van eigen arbeid, kapitaal en grond (indicator C.25). Dit inkomen ligt op ongeveer hetzelfde niveau als voor de vollegrondsgroenteteelt en de melkveehouderij.

Netto toegevoegde waarde en werkgelegenheid akkerbouwcomplex

Het akkerbouwcomplex is wat betreft toegevoegde waarde met circa $€ 26,5$ mld. in 2018 het belangrijkst binnen het totale agrocomplex. Dit is in belangrijke mate (voor bijna 80\%) gebaseerd op buitenlandse grondstoffen afkomstig van de invoer van koffie, thee en cacao, en van plantaardige oliën en vetten. Ook de invoer van veevoergrondstoffen wordt toegerekend aan het akkerbouwcomplex, voor het deel dat aan niet-landbouwsectoren levert of exporteert. De rest van de invoer van veevoergrondstoffen is inbegrepen bij de toelevering van de veehouderijsectoren (citaat op Agrimatie).

Het akkerbouwcomplex is samengesteld uit de primaire akkerbouwbedrijven (10.835 in 2018), de aardappelverwerkende industrie, de spijsoliën-, vetten- en margarine-industrie, de meel- en zetmeelindustrie, de brood- en deegwarenindustrie, de suiker-, cacao-, koffie- en thee-industrie, de drankenindustrie en de tabaksindustrie. Verder vallen ook de toeleveranciers en de distributiebedrijven - voor het deel dat deze sectoren aan de primaire akkerbouwbedrijven of de verwerkende industrieën leveren - onder het akkerbouwcomplex. Het gaat daarbij onder meer om loonwerkbedrijven, de kunstmestindustrie, producenten van gewasbeschermingsmiddelen en landbouwzaden, en zakelijke dienstverlening (citaat op Agrimatie).

De toegevoegde waarde van het akkerbouwbouwcomplex bedroeg in 2018 - het meest recente jaar waarvoor de cijfers beschikbaar zijn - bijna 26,5 mld. euro, dat is circa 3,4\% van het bruto binnenlands product (bbp). Dit aandeel is al een aantal jaar min of meer gelijk. Binnen het op binnenlandse grondstoffen gebaseerde akkerbouwcomplex (ongeveer 5,5 mld. euro) is het aandeel in de toegevoegde waarde van de verschillende schakels de laatste jaren vrij stabiel. De primaire bedrijven hebben een aandeel in de toegevoegde waarde van circa 23\%; dat van de toelevering is met circa $30 \%$ het grootst en de aandelen van verwerking en distributie komen beide uit op circa $24 \%$ (citaat van Agrimatie).

De werkgelegenheid van het akkerbouwcomplex bedroeg in 2018 bijna 260.000 arbeidsjaren. Net als bij de toegevoegde waarde wordt deze werkgelegenheid voor een zeer groot deel (74\%) bepaald door de verwerking, toelevering en distributie van buitenlandse akkerbouwgrondstoffen. De werkgelegenheid die samenhangt met de binnenlandse grondstoffen bedroeg in 2018 ruim 66.000 arbeidsjaren. Hiervan had $26 \%$ betrekking op de primaire akkerbouwbedrijven. De werkgelegenheid lag in zowel de verwerking als de distributie van binnenlandse akkerbouwproducten met respectievelijk $24 \%$ en $21 \%$ op een iets lager niveau. Toeleveranciers hadden met $29 \%$ het grootste aandeel in de werkgelegenheid in het op binnenlandse grondstoffen gebaseerde akkerbouwcomplex (citaat van Agrimatie).

\section{Handelspositie}

Data over de export uitgesplitst naar akkerbouw en opengrondstinbouwsectoren ontbreken, maar wel is het volgende bekend (Jukema et al., 2021):

1. De waarde van de export van kas- en vollegrondsgroenten, aardappelen en uien bedroeg in 2020 7,1 miljard euro. 
2. In 2020 bedroeg de totale exportwaarde van graan, meel en melk circa $€ 5,3$ miljard. Onder bereidingen van graan, meel en melk valt een diverse groep producten, zoals allerlei voedingsbereidingen voor baby's en jonge kinderen, koekjes, pizza's en pastaproducten.

3. De totale export van resten van de voedselindustrie en veevoer bedroeg in $2020 € 5,0$ miljard. Deze groep bevat onder meer sojaschroot, zonnebloemzaadschroot, honden- en kattenvoer, premixes voor veevoer en palmpitschilfers.

4. Nederland exporteerde in 2019 voor $€ 1,5$ miljard aan suiker en suikerwerk.

5. In 2020 bedroeg de exportwaarde van meel, mout en zetmeelproducten $€ 0,8$ miljard.

6. De exportwaarde van granen bedroeg in $2020 € 0,6$ miljard. 


\section{$1.2 \quad$ SWOT-analyse per specifieke doelstelling}

\section{(a) Bieden van steun met het oog op een leefbaar landbouwinkomen en veerkracht in de hele Unie om de voedselzekerheid te vergroten;}

SWOT-samenvatting subdoelstelling A Bieden van steun met het oog op een leefbaar landbouwinkomen en veerkracht in de hele Europese Unie om de voedselzekerheid te vergroten

\begin{tabular}{|c|c|}
\hline & \\
\hline $\begin{array}{l}\text { - Productieomstandigheden, infrastructuur } \\
\text { - Opleidingsniveau, kennisnetwerk } \\
\text { - Innovatief vermogen } \\
\text { - Veerkracht } \\
\text { - Hoge productiviteit per ha } \\
\text { - Sterke vermogenspositie maakt bedrijven weerbaar } \\
\text { - Gezinsbedrijf dominant } \\
\text { - Hoge aandeel berekende kosten vergroot weerbaarheid }\end{array}$ & $\begin{array}{l}\text { - Hoge kostprijs als gevolg van dure grond en arbeid } \\
\text { - Kortdurende pachtcontracten met hoge pachtprijzen } \\
\text { - Inkomens landbouw lager ten opzichte van vergelijkbaar } \\
\text { werk buiten de landbouw } \\
\text { - Merendeel van de huidige bedrijven in de land- en } \\
\text { tuinbouw is te klein om een marktconforme beloning voor } \\
\text { de inzet van eigen arbeid en kapitaal te realiseren } \\
\text { - Onderhandelingspositie in de keten zwak } \\
\text { - Werken buiten de landbouw is financieel aantrekkelijker } \\
\text { - Sterke vermogenspositie (dat wil zeggen hoge } \\
\text { kapitaalsbehoefte bij opvolger) bemoeilijkt } \\
\text { bedrijfsovernames } \\
\text { - Rendement op eigen vermogen en arbeid lager dan in } \\
\text { sectoren buiten de landbouw }\end{array}$ \\
\hline & \\
\hline $\begin{array}{l}\text { - Markt voor nieuwe bedrijfsvormen/verdienmodellen (korte } \\
\text { - } \text { Plantaardige eiwitten uit bijvoorbeeld peulvruchten, } \\
\text { zetmeelaardappel en suikerbiet van belang in transitie } \\
\text { naar plantaardiger dieet } \\
\text { - Vraag naar publieke diensten (nieuw GLB) } \\
\text { - Sterke verstedelijking van het Nederlandse platteland } \\
\text { geeft kansen voor directe verbindingen met de stad via } \\
\text { - } \text { het leveren van producten en diensten } \\
\text { in ontwikkeling multifunctionele landbouw weg te nemen } \\
\text { en ontwikkelruimte te creëren } \\
\text { - Aandacht voor het vergroten van veerkracht } \\
\text { Subsidiemodule agrarische bedrijfsadvisering en educatie } \\
\text { (SABE-regeling) }\end{array}$ & $\begin{array}{l}\text { - Inkomensondersteunende en stabiliserende werking } \\
\text { toeslagen neemt verder af } \\
\text { - Bedrijfsovername niet eenvoudig door kapitaalintensiteit } \\
\text { bedrijven } \\
\text { - Na bedrijfsovername is aantrekken vreemd vermogen } \\
\text { lastig gegeven zware financiering en strengere spelregels } \\
\text { vanuit banken } \\
\text { - Hoge prijs grond en arbeid belemmeren extensivering } \\
\text { - Financieringslasten bij overname } \\
\text { - Aantrekkingskracht werk buiten de sector, jonge boeren } \\
\text { kiezen bewust voor baan buiten de landbouw } \\
\text { (is deels ook een kans omdat het ruimte schept voor andere } \\
\text { bedrijven om door te groeien) } \\
\text { - Ongelijk speelveld; markt neemt producten af uit } \\
\text { buitenland die onder andere - veelal lagere - eisen zijn } \\
\text { geproduceerd }\end{array}$ \\
\hline
\end{tabular}

\section{Sterktes}

De dominante positie van het gezinsbedrijf in de agrarische sector leidt tot een grote betrokkenheid bij het bedrijf, tot flexibele inzet van arbeid om optimaal te zorgen voor de gewassen en voor alle taken op het bedrijf en tot de bereidheid om genoegen te nemen met een lagere dan marktconforme beloning voor de inzet van arbeid en kapitaal. Daardoor vormt dit bedrijfstype een stabiele factor in de agrarische productie. ${ }^{9}$

Niet van toepassing: hoge productiviteit per dier.

\section{Zwaktes}

De sterke vermogenspositie als factor die bedrijfsovernames bemoeilijkt is aangevuld met 'hoge kapitaalsbehoefte bij opvolger'. Een sterke vermogenspositie (laag aandeel schulden) bij de overdrager kan namelijk gunstig zijn, doordat deze wat kan toegeven op de overnameprijs van het bedrijf, waardoor de overnemer een relatief gunstige start kan maken.

\footnotetext{
9 Tegelijkertijd kan de nauwe verwevenheid tussen het gezin en het gezinsinkomen enerzijds en het bedrijf en de bedrijfsresultaten anderzijds tot zorgen leiden over het gezinsinkomen, de financiering van bedrijfsopvolging en de gebondenheid aan het bedrijf.
} 
Een deel van de akkerbouwers met een behoefte aan schaalvergroting schrijft in op kortdurende pachtcontracten met hoge pachtprijzen. Door de hoge pachtprijzen staan de gewassaldi onder druk en is er weinig financiële ruimte om te investeren in de bodemkwaliteit. Daarnaast stimuleert het kortlopende karakter van die contracten deze investeringen ook niet, omdat de baten hiervan mogelijk bij een andere, toekomstige gebruiker terecht kunnen komen en de investeerder er zelf geen baat van heeft.

\section{Kansen}

Productie voor en afzet aan nichemarkten zoals lokale, streek- en/of biologische producten bieden voor een klein deel van de akkerbouwbedrijven perspectief. Dit geldt in het bijzonder (maar niet uitsluitend) voor bedrijven in de nabijheid van grote steden die agf (aardappelen, groenten en fruit) inclusief peulvruchten en graanproducten zoals meel of brood telen en/of verkopen, hetzij aan huis, hetzij via een lokale winkel of winkelketen. In een enkel geval lukt het zelfs het hele land te bedienen, bijvoorbeeld met de 'ambachtelijke chips' uit de Hoekschewaard. In het biologische segment is zelfs sprake van een aanzienlijk aandeel van de producten dat geëxporteerd wordt (Dekking et al., 2020).

Het belang van lokaal geteelde agf en dergelijke neemt toe, maar het marktaandeel is (nog) zeer bescheiden. Deze producten worden veelal rechtstreeks naar de consument afgezet via boerenmarkten, boerderijwinkels en webwinkels.

In de Nationale Eiwitstrategie is de ambitie verwoord om binnen 10 jaar van 15.000 naar 100.000 ha eiwitgewassen op te schalen (zie ook Agrimatie). Plantaardige eiwitten uit bijvoorbeeld peulvruchten, zetmeelaardappel en suikerbiet van belang in transitie naar een plantaardiger dieet. In een dieet met minder vlees en zuivelproducten kunnen plantaardige eiwitten een goede rol spelen. Voor een deel waren die producten al beschikbaar, voor een ander deel wordt hier aan gewerkt, zoals met het concept van de 'Vegetarische Slager'. Daarnaast vormen gewassen of onderdelen daarvan steeds meer de basis voor een biobased economy, dat wil zeggen het gebruik van hernieuwbare grondstoffen voor plastics en andere kunststoffen, lijm, bouwmaterialen, papier etc. uit bijvoorbeeld zetmeelaardappelen en vezelhennep (Harmsen et al., 2014).

\section{Verbreding/multifunctionele landbouw}

Naast productniches, kan een ondernemer ook kiezen voor verbreding/multifunctionele landbouw als neventak. Ongeveer $25 \%$ van de Nederlandse boeren en tuinders pakt naast de akkerbouw, tuinbouw of veeteelt ook andere - maatschappelijke - activiteiten op als zorglandbouw, kinderopvang, boerderijeducatie, boerderijverkoop, natuurbeheer en/of recreatie (Meulen et al., 2019). In hoeverre akkerbouwbedrijven hierbij betrokken zijn, is niet bekend. Het onderzoek van Meulen et al. maakt geen onderscheid naar bedrijfstypen. Op akkerbouwbedrijven worden vooral energieproductie, loonwerk en stalling toegepast; natuurbeheer, recreatie en zorg komen minder voor dan op melkveebedrijven.

\section{Bedreigingen}

\section{Veranderingen in het GLB}

Het aandeel van de steun via het GLB in het inkomen van akkerbouwers is over het algemeen genomen significant. Het aandeel van de toeslagen in het inkomen was in de periode 2013-2017 voor het gemiddelde land- en tuinbouwbedrijf 23\%, met uitschieters naar meer dan $50 \%$ voor bijvoorbeeld de zetmeelbedrijven (Berkhout et al., 2019). Voor de nieuwe GLB-periode (vanaf 2023) moet een toenemend aantal eisen worden verwacht om in aanmerking te komen voor de basistoeslag (de zogenaamde verhoogde conditionaliteit). Daarnaast zal het mogelijk worden om te kiezen voor een ecopakket, waarmee bovenwettelijke eisen op het gebied van biodiversiteit en klimaat kunnen worden ingevuld en vergoed. Overigens kunnen aanpassingen in het GLB ook leiden tot innovaties in de sector. Zo is de belangstelling van AVEBE en Cosun Beet Company voor productie van plantaardige eiwitten uit respectievelijk zetmeelaardappelen en suikerbieten deels ontstaan door lagere afzetprijzen door ontkoppeling van de zetmeelsteun en afschaffing van het suikerquotum. Daarbij hoort dan natuurlijk wel een marktontwikkeling waarbij daadwerkelijk vraag naar dergelijke producten aanwezig is of ontstaat. Voor zulke aanpassingen, zowel op het primaire bedrijf als in de keten kan een afname van de inkomenssteun een prikkel tot innovatie zijn, mits er een goede samenwerking is tussen 
sector, keten en onderzoek, het innovatief vermogen op orde is en er een gunstig ondernemersklimaat is (Smit et al., 2013).

\section{Bedrijfsovername}

In de Landbouwtelling wordt eens in de vier jaar gevraagd of er een bedrijfsopvolger aanwezig is. Deze vraag wordt gesteld aan bedrijfshoofden van 50 jaar of ouder met een bedrijf zonder rechtspersoonlijkheid, zoals een eenmanszaak, maatschap, commanditaire vennootschap of vennootschap onder firma. Bij een bedrijfsvoering die uit meerdere personen bestaat, wordt gevraagd naar de leeftijd van het bedrijfshoofd met de grootste zakelijke en bedrijfsmatige verantwoordelijkheid in het bedrijf. Als de bedrijfshoofden evenveel verantwoordelijkheid hebben, dan wordt gevraagd naar de leeftijd van de oudste ondernemer.

In de akkerbouw is het aandeel bedrijven met rechtspersoonlijkheid betrekkelijk gering. Het aandeel bedrijven met als rechtsvorm een natuurlijke persoon en een bedrijfshoofd van 51 jaar of ouder is tussen 2012 en 2016 gestegen van 64 naar 71\%, maar in 2020 was het aandeel gedaald tot $68 \%$. Daarvan is het aantal bedrijven met opvolging tussen 2012 en 2016 toegenomen van 34 naar 37\%; ook in 2020 was dit aandeel 37\%. Kortom, in de akkerbouw lijkt de veroudering van het ondernemersbestand tot stilstand gekomen evenals de afgenomen belangstelling voor bedrijfsopvolging (tabel C.16). 
(b) Vergroten van de marktgerichtheid en van het concurrentievermogen, onder meer door beter te focussen op onderzoek, technologie en digitalisering;

SWOT-samenvatting subdoelstelling B - Vergroten van de marktgerichtheid en van het concurrentievermogen, onder meer door beter te focussen op onderzoek, technologie en digitalisering

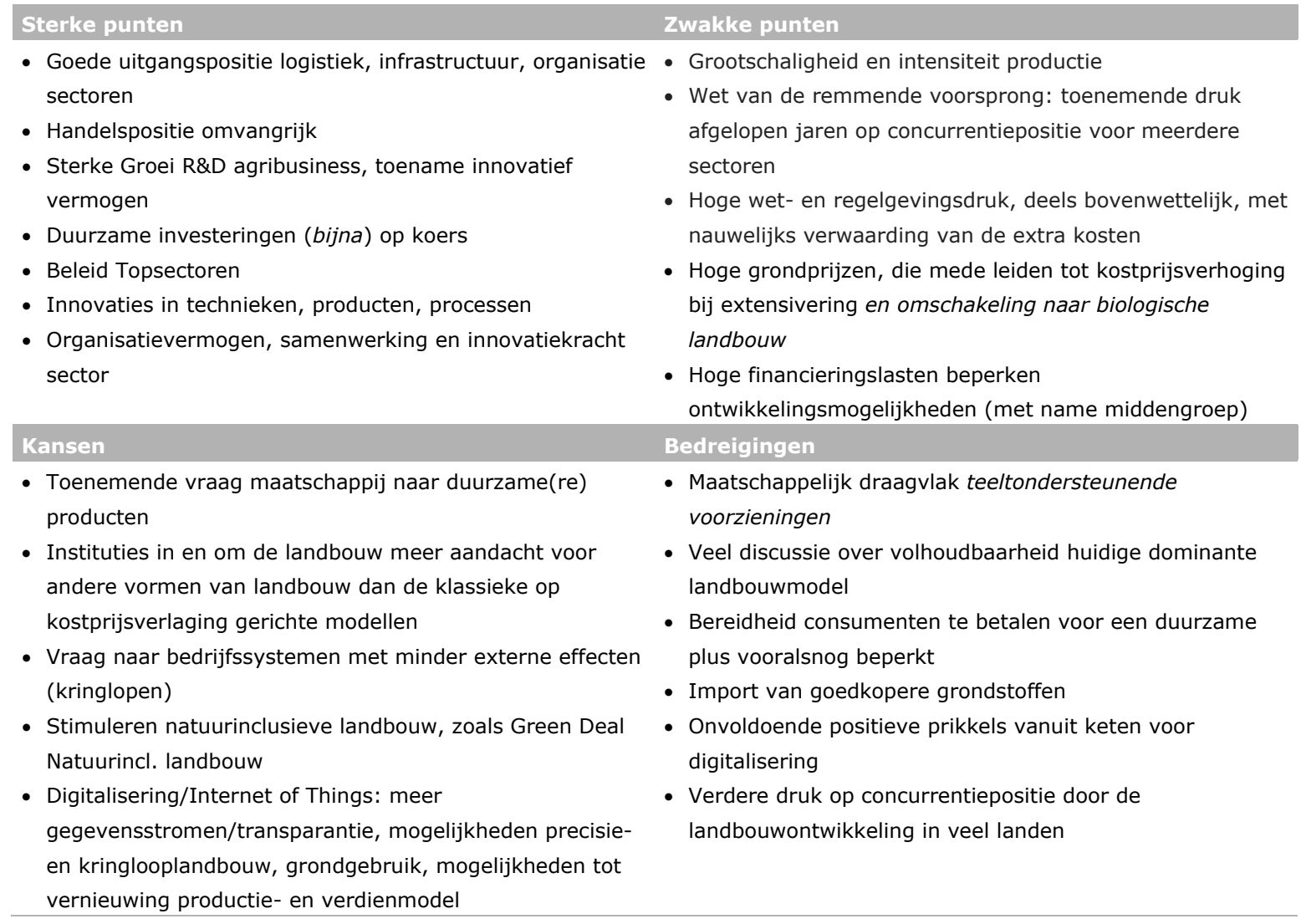

\section{Sterktes}

Innovatief vermogen (waaronder uitgaven aan $R \& D$ )

In de akkerbouw vond in 2018 relatief veel vernieuwing plaats (Van Galen en Van der Meer, 2020). $22 \%$ van de akkerbouwers behoorde tot de innovatoren $(2 \%)$, de vroege volgers (10\%) of de late volgers $(10 \%)$. Het beperken van energiegebruik, afvalstromen en het gebruik van gewasbeschermingsmiddelen wordt door de meeste ondernemers belangrijk gevonden. Ook samenwerking met andere bedrijven wordt door ongeveer $60 \%$ van de bedrijven belangrijk of zeer belangrijk gevonden, met name door ondernemers in de akkerbouw. Hetzelfde geldt voor verhoging van de biodiversiteit (citaat uit Van Galen en Van der Meer, 2020). Tegelijkertijd vinden in de akkerbouw weinig ondernemers hun eigen positie in de keten sterk.

\section{Duurzame investeringen}

Eind 2020 viel 43.628 ha plantaardige productie onder PlanetProof. Dat gaat vooral om vollegrondsgroenten. Het aandeel akkerbouw met het keurmerk 'On the way to PlanetProof' is laag. Een sterke stijging van dit areaal is in 2021 niet waarschijnlijk omdat de retail hier niet om vraagt. In 2020 zijn er proeven gedaan met peulvruchten en zomergroenten. Telers ontvangen hiervoor een extra vergoeding van afnemer HAK, is de belofte. Er is ook kritiek, vooral op de administratieve lasten en de teelt- en afzetrisico's en marktconforme vergoedingen. Het draagvlak in de akkerbouwsector is klein.

Het belang van biologische teelt neemt toe door een toenemend aantal biologische akkerbouwers bij een afname van het totaal aantal akkerbouwers in Nederland (Agrimatie). Omschakeling van gangbare naar biologische akkerbouw/vollegrondsgroenteteelt betekent meestal ook een omschakeling naar andere afzetkanalen, zodat bijvoorbeeld in apparatuur voor wassen, koelen, inpakken en afleveren van producen moet worden geïnvesteerd. Een dergelijke omschakeling betekent meestal ook een 
toename van het aantal gewassen op het bedrijf, met bijbehorende werktuigen, en investeringen in mechanische onkruidbestrijding.

Voor de akkerbouwbouwbedrijven zijn door de coronacrisis naast mogelijke acute liquiditeitsproblemen vooral voor de wat langere termijn onzekerheden in de markt ontstaan. Hierdoor zullen bedrijven niet noodzakelijke investeringen uitstellen tot de gevolgen van de coronacrisis duidelijker zijn. Het totale investeringsniveau zal dalen maar als er geïnvesteerd kan worden zal dat gezien ontwikkelingen uit de markt veelal op een duurzame manier gebeuren. Totale investeringen zullen niet boven die van 2019 uit komen. Hiervoor zijn de onzekerheden te groot (Van der Meulen et al., 2020).

\section{Organisatie}

Een belangrijk deel van de telers levert hun producten aan grote handels- en verwerkingsbedrijven, zoals AVEBE (zetmeelaardappelen), Cosun Beet Company (suikerbieten), Aviko/LambWestonMeijer/McCain/Farm Frites (fritesaardappelen), Nedato (tafelaardappelen) en Agrifirm (granen). De meeste van deze organisaties hebben een coöperatieve structuur, zodat de telers als lid eigenaar en stemgerechtigde zijn wat betreft het bestuur van de organisaties. Gezamenlijk probeert men tot een goed verdienmodel met goede productprijzen voor de telers te komen. Voor de mainstream van akkerbouwers is dit een goed organisatiemodel. De teelt van gewassen vraagt een hoog niveau van vakmanschap, wat niet altijd samengaat met competenties op het gebied van logistiek, productontwikkeling en -afzet. Het kan dan een goede keuze zijn om deze werkzaamheden uit te besteden aan deskundigen in bijvoorbeeld een coöperatieve verwerker en afzetorganisatie die zich daarop kunnen richten en bijdragen aan het verdienmodel van de telers zelf. Een coöperatief model biedt daarbij voordelen in vergelijking met een privaat model (zie bijvoorbeeld Bijman et al., 2012).

\section{Zwaktes}

Op milieugebied zijn duidelijke stappen gezet, maar nog niet alle doelen zijn bereikt. De inzet van gewasbeschermingsmiddelen is de laatste jaren vrijwel constant en het energiegebruik neemt niet toe.

Wat betreft gewasbescherming, in de nota Gezonde Groei, Duurzame Oogst is afgesproken om het aantal overschrijdingen van de Maximaal Toelaatbare Risico's (MTR) van gewasbeschermingsmiddelen in het water (ten opzichte van 2009-2011) terug te dringen met 50\% in 2018 en 90\% in 2023. Om deze ambities te halen moest de emissie van gewasbeschermingsmiddelen (afhankelijk van het bedrijfstype) in 2018 worden verminderd met $60-80 \%$ en met $95-99 \%$ in 2023 . Het PBL (2019) signaleert dat het aantal gemeten overschrijdingen van de waterkwaliteitsnormen voor chronische blootstelling van waterorganismen aan gewasbeschermingsmiddelen in de periode 2016-2018 met $30 \%$ is afgenomen ten opzichte van de referentie 2011-2013; voor de acute norm is de afname $50 \%$. Ondanks deze positieve trend constateert het PBL dat de tussendoelstelling in genoemde nota voor 2018 niet gehaald is.

Wat betreft energiegebruik, in de akkerbouw en veehouderij moest in 2020 een reductie aan 'overige broeikasgassen' (methaan en lachgas) in de akkerbouw en veehouderij van 4,0 tot 6,0 Mton gehaald worden ten opzichte van 1990. Die reductie kwam in 2018 uit op 6,7 Mton, waarmee het gestelde doel voor 2020 ruimschoots is gerealiseerd. Hierbij moet worden opgemerkt dat de daling van methaan en lachgas vooral vóór 2012 plaatsvond als gevolg van het mest- en ammoniakbeleid. Zie ook doel d.

Door aanscherpingen binnen het mestbeleid is het stikstof- en fosfaatoverschot eveneens verkleind. Een aandachtspunt in dit verband is de hoge nitraatuitspoeling op percelen met bladgewassen op de zand- en lössgronden. Het doel is om onder de Europese norm van $50 \mathrm{mg} / \mathrm{l}$ grondwater te blijven, maar dat blijft met name in deze regio's lastig. De gemeten waarden dalen, maar met name in droge jaren worden toch weer overschrijdingen geconstateerd (Agrimatie). Zie verder doelstellingen d en e.

Een ander zwak punt zijn de hoge grondprijzen van goede landbouwgrond. Dit maakt extensivering moeilijk, bijvoorbeeld voor telers die richting natuurinclusieve of biologische landbouw willen ontwikkelen. 


\section{Kansen}

Het imago van de akkerbouw is over het algemeen goed. Problemen met dierenwelzijn en van dier op mens overdraagbare ziektes bijvoorbeeld doen zich in deze sector niet voor. Een uitzondering is de chemische gewasbescherming, waarover wel zorgen zijn (zie Bedreigingen).

De transitie naar een meer plantaardig dieet is een positieve prikkel voor de akkerbouwsector.

\section{Bedreigingen}

Het imago van de akkerbouw is over het algemeen goed. Toch blijft het gebruik van gewasbeschermingsmiddelen en de eventuele gevolgen voor de volksgezondheid en de biodiversiteit (zoals bijen) een gevoelig punt. Met enige regelmaat meldt de pers over zorgen bij burgers en natuurbeschermers op dit thema. Toch (of mede daarom) ondergaat het gewasbeschermingsbeleid momenteel grote veranderingen. Het aantal beschikbare middelen blijft dalen en de inzet is 'weerbare planten en gewassen' geworden (Bremmer et al., 2020). Mogelijk dat dit aangepaste beleid door telers als een bedreiging wordt ervaren, omdat de huidige toepassingspraktijken met een breed (maar smaller wordend) scala aan gewasbeschermingsmiddelen als tamelijk bedrijfszeker wordt ervaren; voor een systeemverandering met zeer minimale inzet van deze middelen zijn nu nog niet alle hulpmiddelen ontwikkeld en/of bedrijfszeker. Dat geeft zorgen over het op peil houden van gewasopbrengsten en -kwaliteit en dus indirect ook over de continuïteit van de bedrijven.

Wat betreft de internationale concurrentiepositie van de biologische landbouw, die is over het algemeen goed, gezien het feit dat het bijvoorbeeld in de belangrijkste Nederlandse provincie in dit opzicht, Flevoland, lukt om ongeveer de helft van de biologische productie in het buitenland af te zetten (Dekking et al., 2020). Dit is echter een kwetsbare positie, omdat veel Europese consumenten (buiten Nederland) een voorkeur hebben voor lokaal geproduceerd biologisch voedsel. Regelgeving in bijvoorbeeld Duitsland gaat dit mogelijk ook eisen, waardoor de mogelijkheden om het exportvolume van biologische producten verder toe te laten nemen in gevaar zullen komen. Daarbij blijft tot op heden de toename van de vraag naar biologische producten in Nederland achter. Dit zal naar verwachting de komende jaren niet wezenlijk gaan veranderen, omdat het merendeel van de Nederlandse consumenten vooral voor goedkoop voedsel kiest, hetzij noodgedwongen door een laag inkomen, hetzij doordat men ervoor kiest om het beschikbare budget aan andere zaken uit te geven (Jongeneel et al., 2020). 


\section{(c) Verbeteren van de positie van de landbouwers in de waardeketen;}

\section{SWOT-samenvatting subdoelstelling C Verbeteren van de positie van de landbouwers in de}

waardeketen

\begin{tabular}{|c|c|}
\hline Sterke punten & Zwakke punten \\
\hline $\begin{array}{l}\text { - Hoog kennis en opleidingsniveau } \\
\text { - Uitgebreid kennisnetwerk dat kan bijdragen } \\
\text { - Goed ondernemerschap } \\
\text { - Innovatiekracht } \\
\text { - Samenwerking in de vorm van coöperaties, } \\
\text { belangenbehartiging } \\
\text { - Dichtbij afzetmarkt - kleine afstand stad/land } \\
\text { - Logistiek } \\
\text { - Opkomst korte ketens } \\
\text { - Groei multifunctionele landbouw, met Boer-burger contact } \\
\text { - Goede koel- en bewaarfaciliteiten op veel } \\
\text { - Poolsystemen voor met name consumptieaardappelen en } \\
\text { - } \text { Aien }\end{array}$ & $\begin{array}{l}\text { - Onderhandelingspositie in de keten } \\
\text { - Beperkt aandeel in consumenteneuro } \\
\text { - Import andere kwaliteit, moeilijk mee te concurreren op } \\
\text { prijs } \\
\text { - Groot aandeel contracten in de consumptieaardappelteelt }\end{array}$ \\
\hline Kansen & Bedreigingen \\
\hline $\begin{array}{l}\text { - Ondersteuning vanuit beleid (nationaal en provinciaal) } \\
\text { - Platform Multifunctionele Landbouw } \\
\text { - Versterking band boer-burger via nieuwe } \\
\text { bedrijfsvormen/verdienmodellen } \\
\text { - Belangstelling voor kwaliteitsproducten stijgt, dat geldt } \\
\text { ook voor biologische landbouw } \\
\text { - Belonen van duurzaamheidsprestaties door verwerkers en } \\
\text { consument } \\
\text { - Met producentenorganisaties rol in de keten versterken } \\
\text { - Nieuwe regelgeving om oneerlijke handelspraktijken } \\
\text { tegen te gaan } \\
\text { - Digitalisering biedt ondernemerschap kansen (in korte } \\
\text { ketens) }\end{array}$ & $\begin{array}{l}\text { - Groei van korte ketens/niches, waaronder biologische } \\
\text { landbouw, kan leiden tot een druk op de prijs } \\
\text { - In dunner bevolkte gebieden minder perspectief voor } \\
\text { korte ketens } \\
\text { - Wet- en regelgeving kan kleine vernieuwende } \\
\text { ondernemers dwarsbomen } \\
\text { - Handelsverdragen met landen met minder } \\
\text { regels/wetgeving kunnen leiden tot ongelijk speelveld }\end{array}$ \\
\hline
\end{tabular}

\section{Sterktes}

Goede koel- en bewaarfaciliteiten op veel akkerbouwbedrijven maken het mogelijk om de afzet van de producten (aardappelen, uien, granen, vollegrondsgroenten zoals winterpeen) te spreiden over het afzetseizoen, niet afhankelijk te zijn van de prijsvorming direct na de oogst en daarmee de risico's te kunnen spreiden over langere tijd. Poolsystemen voor met name consumptieaardappelen en uien helpen eveneens om prijsrisico's te spreiden en de verkoop van de producten aan gespecialiseerde verkopers uit te besteden.

\section{Zwaktes}

Door een groot aandeel contracten in de consumptieaardappelteelt (met name de fritesaardappelteelt) is er nauwelijks nog sprake van marktwerking in die sector (nog afgezien van coronaperikelen; zie Berkhout et al., 2020 en Janssens et al., 2020). Aangezien de prijzen die in contracten worden afgesproken, vooral gedicteerd worden door de verwerkende industrie, heeft de teler dus nauwelijks invloed op de prijsvorming. Evenwel kan in een jaar met slechte marktprijzen (zoals in coronajaar 2020) een contract een bepaalde zekerheid bieden; daarom is dit ook een sterkte. Dat is ook de reden dat financiers vaak om contracten vragen; ze voorzien in een stuk zekerheid. Gemiddeld wordt dan niet de hoogste prijs behaald, maar sterke schommelingen, met name naar beneden, worden wel gedempt.

\section{Kansen}

Producenten Organisaties spelen in de akkerbouw momenteel nauwelijks een rol van betekenis. Een relatief groot deel van de sector is coöperatief georganiseerd, waarbij de coöperatie namens de leden- 
agrariërs bij de afzet een goede prijs voor de producten probeert te realiseren. Producenten Organisaties zouden een rol kunnen spelen in ketens waarin de producten afgezet worden bij private partijen. De Nederlandse Akkerbouwvakbond (NAV) heeft dit idee uitgewerkt in de consumptieaardappelsector. Dat heeft geleid tot de oprichting en erkenning van de Producentenorganisatie Consumptieaardappelen (POC).

Een deel van de akkerbouwers ziet kansen door hun productie te richten op nichemarkten, zoals streek- en biologische producten en die via korte ketens af te zetten. Directer contact met de klant kan daarvoor een reden zijn, maar ook vergroting van het aandeel van de consumentenprijs dat bij de teler zelf terecht komt.

\section{Bedreigingen}

Tegenover kansen bij een keuze voor nichemarkten staan dikwijls ook hogere kosten, zodat een vergroting van het aandeel in de marge niet bij voorbaat zal leiden tot een hoger inkomen. Bovendien kan door een gestage groei van korte ketens/niches, prijsdruk ontstaan. Het gaat vaak om kleine markten die relatief snel verzadigd zijn of, bij korte ketens, om een relatief klein aantal vaste afnemers. Er is dus beperkte ruimte voor de sector om zich in deze richting te ontwikkelen tenzij er een grote groei komt vanuit de vraagkant, maar daarvoor is dan wel inzet nodig van de overheid en andere partijen. 


\section{(d) Bijdragen tot matiging van en aanpassing aan klimaatverandering en tot duurzame energie;}

SWOT-samenvatting subdoelstelling D Bijdragen aan mitigatie en adaptatie aan klimaatverandering en leveren van een bijdrage aan een duurzame energieproductie

\begin{tabular}{|c|c|}
\hline Sterke punten & Zwakke punten \\
\hline $\begin{array}{l}\text { - Veel mogelijkheden voor klimaatadaptatie en -mitigatie } \\
\text { - Publiek-private samenwerking om klimaatopties toe te } \\
\text { - Kennis om te innoveren } \\
\text { - Initiatieven van ketenpartijen } \\
\text { - Uitstoot broeikasgassen relatief laag } \\
\text { - Sector produceert meer wind- en zonne-energie dan hij } \\
\text { zelf verbruikt } \\
\text { - Verwerkende industrie (Cosun Beet Company, AVEBE, } \\
\text { etc.) hebben al grote stappen gezet op het gebied van } \\
\text { duurzaam energiegebruik }\end{array}$ & $\begin{array}{l}\text { - Goedkope fossiele brandstoffen vertragen transitie } \\
\text { - Toepassing van wind- en zonne-energie is nog afhankelijk } \\
\text { van subsidies } \\
\text { - Teelt biomassa kan niet concurreren met teelt } \\
\text { akkerbouwgewassen } \\
\text { - Belemmeringen op het vlak van afval- en mestwetgeving } \\
\text { - staan hergebruik van stoffen in de weg } \\
\text { - Productie van kunstmest kost veel energie }\end{array}$ \\
\hline
\end{tabular}

Over de productie van hernieuwbare energie (C.41) zijn geen cijfers beschikbaar voor de akkerbouw, hetzelfde geldt voor de emissie van broeikasgassen (indicator C.43). Wel is bekend dat:

- $48 \%$ van de akkerbouwers hernieuwbare energie produceert, met name zonne- en windenergie (met een aandeel van $16 \%$ voor deze laatste bron in de akkerbouw en een gemiddeld aandeel van zonneenergie van $85 \%$ over de hele land- en tuinbouwsector heen) (RVO, 2020).

- De veehouderij en de akkerbouw in 2018 een reductie aan 'overige broeikasgassen' (methaan en lachgas) hadden behaald van 6,7 Mton, waarmee het gestelde doel voor 2020 (4,0 tot 6,0 Mton) toen al ruimschoots was gerealiseerd.

Voor C.41 gaat het om het plaatsen van zonnepanelen en windmolens. Hierover zijn geen gegevens beschikbaar.

Voor C.43 geldt dat de uitstoot vooral betrekking heeft op het energiegebruik. Dit is beperkt in de akkerbouw tot het gebruik van machines en tot in- en uitschuren, drogen, sorteren en bewaren van producten. Het energiegebruik op akkerbouwbedrijven liet lang een stijgende lijn zien. Dit werd vooral veroorzaakt door de toenemende bedrijfsomvang. In 2018 stabiliseerde het energiegebruik op een niveau van $620 \mathrm{GJ}$ per bedrijf. Het grootste deel van het energiegebruik bestaat uit het gebruik van diesel (ongeveer 75\%).

Volgens de Eindrapportage van het Convenant Schone en Zuinige Agrosectoren (RVO, 2020), bedroeg het verbruik in de akkerbouw in $20184,1 \mathrm{Pj} .{ }^{10}$ In de akkerbouw en open teelten bestaat het energiegebruik voor ruim de helft uit motorbrandstoffen (onder andere grondbewerking, oogst, beregening). Het elektra- en gasverbruik dragen elk bijna voor $25 \%$ bij. Het elektra-verbruik (vooral voor drogen en bewaren van producten) is afgelopen 15 jaar behoorlijk stabiel. Het gasverbruik is na een stijging tot 2009 weer gedaald naar een niveau, vergelijkbaar met 2002.

\section{Sterktes}

De uitstoot van broeikasgassen is in de akkerbouw relatief laag. Een groot deel hangt samen met de inzet van machines, maar door innovaties in motoren van tractoren, maaidorsers en andere

\footnotetext{
101 Peta Joule $=10^{12}$ kJoule.
} 
zelfrijdende machines neemt de energie-efficiëntie toe en daarmee de emissie per kW af. Daarbij is er nog een tendens om minder intensieve grondbewerking toe te passen, wat zowel het dieselgebruik beperkt als de emissie van stikstofoxiden. Ook de inzet van aangepaste machines wat betreft bandenbreedte en -druk draagt hieraan bij (Silvis et al., 2015).

Een ander gunstig aspect is dat de akkerbouwsector meer wind- en zonne-energie produceert dan het zelf verbruikt. Dit gebeurt vooral door zonnepanelen op boerderijdaken en windmolens. Ook de verwerkende industrie (Cosun Beet Company, AVEBE, etc.) hebben al grote stappen gezet op het gebied van duurzaam energiegebruik. De energie-efficiëntie van hun bedrijfsprocessen, met name van de verwerking, is door toepassing van innovatieve technologie in de afgelopen jaren sterk toegenomen. Daarbij worden restproducten, voor zover niet verder opgewaardeerd in deze of andere ketens, gebruikt voor energieproductie, zoals groen gas, waarop bijvoorbeeld (aangepaste) vrachtwagens kunnen rijden (Smit en Janssens, 2016).

\section{Zwaktes}

In de akkerbouw wordt weliswaar steeds meer dierlijke mest gebruikt, maar een aanzienlijk deel van de N-behoefte wordt ingevuld met kunstmest. De productie daarvan kost veel (vaak fossiele) energie, al zijn er grote verschillen in energie-efficiëntie tussen de kunstmestfabrieken in verschillende landen. Het aandeel kunstmest in de $\mathrm{N}$-bemesting is overigens de afgelopen jaren wel gedaald, namelijk van $55 \%$ naar $46 \%$ in 2021 , terwijl de totale $\mathrm{N}$-bemesting in de akkerbouw ook is afgenomen (Agrimatie).

\section{Kansen}

Geen aanvullingen.

\section{Bedreigingen}

Een groot deel van de Nederlandse akkerbouwproductie is bestemd voor export. Daarvan gaat een groot deel naar andere EU-lidstaten, waarin de eisen over duurzaamheid in grote lijnen vergelijkbaar zijn als in Nederland. De concurrentieverhoudingen worden binnen de EU niet geschaad door de hoge eisen die aan Nederlandse producten worden gesteld ('level playing field'). Voor export naar 'derde' landen ligt dat anders, omdat die landen aan hun eigen telers niet dezelfde eisen stellen als voor de Nederlandse telers gelden. De concurrentiepositie van de Nederlandse sector wordt negatief beïnvloed door een hoog kostenniveau als gevolg van hoge eisen tegenover goedkopere maar minder duurzame en veilige producten uit die landen zelf. Over het algemeen lukt het niet om onze hoogwaardige producten tegen een passende prijs af te zetten in dergelijke landen. Onze exportpositie wordt daardoor geschaad.

Klimaatverandering kan leiden tot het optreden van nieuwe plagen, ziekten en onkruiden in Nederland. Door gemiddeld hogere temperaturen en minder koude winters kunnen aantasters die voorheen in Nederland niet voorkwamen of zich hier niet konden vermeerderen, zich in de toekomst ook in Nederland handhaven. In combinatie met afnemende beschikbaarheid van chemische gewasbeschermingsmiddelen en minimalisering van de inzet daarvan kunnen dergelijke aantasters tot ernstige bedreigingen voor de teelt van diverse gewassen leiden. Het is evenwel moeilijk te voorspellen hoe groot die bedreigingen zijn. 


\section{(e) Bevorderen van duurzame ontwikkeling en efficiënt beheer van natuurlijke}

hulpbronnen zoals water, bodem en lucht;

SWOT-samenvatting subdoelstelling E Bevorderen van duurzame ontwikkeling en efficiënt beheer van natuurlijke hulpbronnen, zoals water, bodem en lucht

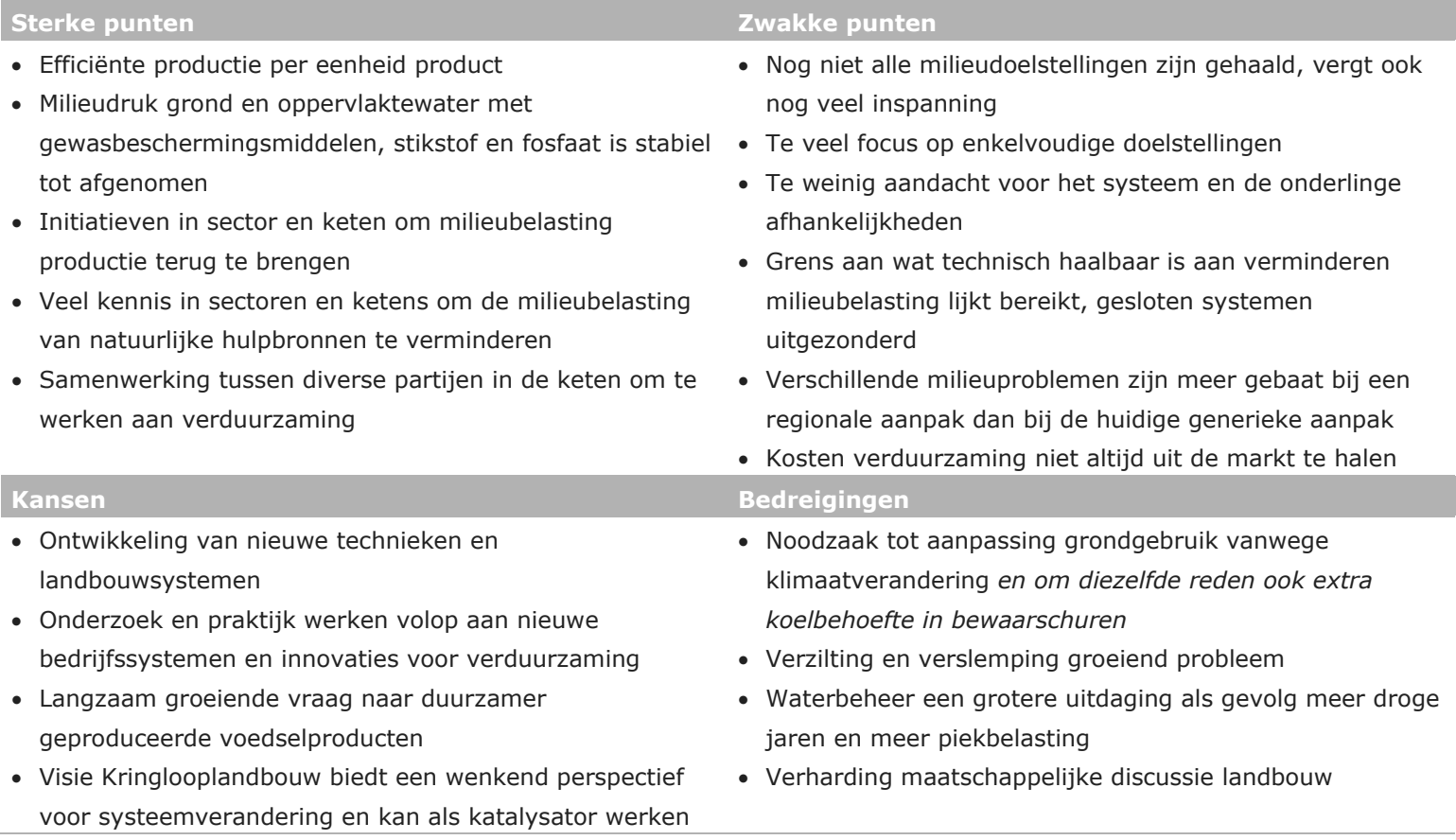

Voor de SWOT-analyse van subdoelstelling (e) zijn de contextindicatoren C.37 watergebruik in de landbouw, C.38 waterkwaliteit, C.39 organisch stofgehalte bouwland, C.40 bodemerosie als gevolg van water en C.48 risico en effect van gewasbeschermingsmiddelen relevant. Op basis van nationale data - op basis van Eurostat zijn geen gegevens voorhanden - is het beeld voor de akkerbouw inclusief een aantal vollegrondsgroenteteelten als volgt.

\section{Gewasbescherming}

De kosten van het gewasbeschermingsbeleid zijn sinds 2010 voor de meeste gewassen gelijk gebleven of licht gestegen. Het meest stegen de kosten bij de teelt van spruitkool (19\%), pootaardappelen $(7 \%)$ en aardbei $(2 \%)$. De oorzaak is dat in deze teelten middelen vervallen zijn en minder effectieve alternatieven beschikbaar zijn gekomen (PBL, 2019).

Vergeleken met omliggende landen zijn de kosten voor de teler om te voldoen aan het gewasbeschermingsbeleid in Nederland iets hoger. Een oorzaak is dat in het omliggende buitenland iets meer middelen zijn toegelaten (1.020 in Nederland versus 1.114 gemiddeld in de centrale zone). Dit wordt voornamelijk veroorzaakt door verschillen in de toelating, maar ook doordat producenten van gewasbeschermingsmiddelen niet altijd een aanvraag doen voor een toelating in Nederland. Hierdoor kunnen gewasbeschermingsproblemen in het buitenland iets effectiever worden aangepakt (PBL, 2019).

Uit de meest recente nalevingsmetingen van de Nederlandse Voedsel-en Warenautoriteit (NVWA) blijkt dat het nalevingsniveau in de fruitteelt, sierteelt onder glas, akkerbouw, vollegrondsgroenteteelt en de bloembollenteelt varieert van 80 tot $90 \%$ (PBL, 2019).

\section{De berekende milieubelasting en emissies zijn afgenomen}

De akkerbouw verbruikte in 2016 bijna 3,6 miljoen kilogram chemische gewasbeschermingsmiddelen, waarvan 2,3 miljoen kilogram voor de bescherming van aardappelen. Dat is $40 \%$ van alle chemische middelen die in 2016 in de landbouw zijn verbruikt. (PBL, 2019). Met name de bestrijding van Phytophthora infestans in aardappelen leidt tot een relatief grote inzet en daarom wordt sterk ingezet op resistentieveredeling, bijvoorbeeld in het PPS-project ResPot (Towards a RESilient POTato cropping 
system, TKI-nummer LWV200237). Verder heeft het verbod op neonicotinoïden in de suikerbietenteelt geleid tot een daling van de milieubelasting door insecticiden, maar het voorkomen van vergelingsziekte door vliegende insecten blijft lastig en vraagt om innovaties. Vooral de milieubelasting van het grondwater is gedaald, terwijl de belasting van het oppervlaktewater juist is toegenomen. Dat laatste is vooral veroorzaakt door grootschalige toepassing van het voor waterleven zeer belastende tefluthrin. Het verbod op neonicotinoïden was bedoeld om het risico voor bijen te beperken en de toepassing van middelen met dat risico is inderdaad afgenomen van 95 naar 55\% (CLM, 2020). In tegenstelling tot diverse ons omringende landen heeft Nederland daarom geen vrijstelling op dit verbod gegeven.

In de akkerbouwsector wordt relatief sterk gewerkt aan emissiereductie en ook, maar in mindere mate, aan preventie door bijvoorbeeld resistente en tolerante rassen in te zetten, aan inzet van teelttechnische maatregelen. In de akkerbouw en het loonwerk vallen vooral de sterke stijging van GPS-systemen en het toegenomen gebruik van beslissingsondersteunende systemen (BOS-en) op. Digitale technieken zullen van toenemend belang worden voor de verduurzaming van de gewasbeschermingspraktijk in de sector (PBL, 2019).

In de akkerbouw is het verbruik van gewasbeschermingsmiddelen tussen 2012 en 2016 met $10 \%$ toegenomen (van 5,03 naar 5,53 miljoen $\mathrm{kg}$ ) actieve stof. De milieubelasting is met 39\% gestegen, deze belasting wordt uitgedrukt in milieu-indicatorpunten (MIP), een maat voor het aantal normoverschrijdingen uitgedrukt in toxische eenheden. De emissies naar het oppervlaktewater zijn gedaald. $90 \%$ van de akkerbouwers past inmiddels spuitdoppen toe die de drift (het verwaaien van de spuitnevel) met 90 procent reduceren. Aangezien drainage de belangrijkste emissieroute is, wordt de afname waarschijnlijk mede veroorzaakt door een verschuiving naar middelen die minder sterk uitspoelen. De milieubelasting door de open teelten wordt gedomineerd door drie stoffen, namelijk de insecticiden deltamethrin, lambda-cyhalothrin en esfenvaleraat. Samen zijn ze goed voor circa $90 \%$ van de berekende belasting van het oppervlaktewater (PBL, 2019).

De afgelopen jaren (sinds 2016) is de inzet van gewasbeschermingsmiddelen per ha akkerbouw evenwel gedaald tot onder $8 \mathrm{~kg} / \mathrm{ha}$ (Agrimatie), met name door een lagere inzet van fungiciden. De milieubelasting (uitgedrukt in milieubelastingspunten) is sinds 2016 nagenoeg stabiel gebleven (Agrimatie). Ook het aantal overschrijdingen van de Maximaal Toelaatbare Risico's (MTR) van gewasbeschermingsmiddelen in het water neemt de afgelopen jaren af (Agrimatie).

\section{Sterktes}

Op milieugebied worden stappen gezet. De inzet van gewasbeschermingsmiddelen per ha neemt sinds 2016 weer af. Het energiegebruik neemt niet toe (zie analyse bij doelstelling d). Door aanscherpingen binnen het mestbeleid is het stikstof- en fosfaatoverschot eveneens verkleind. Het gemiddelde stikstofbedrijfsoverschot in 2019 op akkerbouwbedrijven bedroeg $72 \mathrm{~kg}$ stikstof per ha en was $8 \%$ lager dan in 2014-2018 (Agrimatie). Het gemiddelde fosfaatbedrijfsoverschot op akkerbouwbedrijven is al sinds 2005 (50 kg P2O5 per ha) afgenomen tot $10 \mathrm{~kg} \mathrm{P2O5}$ in 2019 (met een piek in 2018 als gevolg van de droogte in dat jaar) (Agrimatie).

\section{Zwaktes}

Niet-chemische zoals preventieve en mechanische gewasbeschermingsmethoden worden relatief weinig ingezet in de akkerbouw. Er is een fundamentele stap van een systeem gebaseerd op chemische bestrijding naar een systeem gebaseerd op weerbare planten en gewassen nodig (Bremmer et al., 2020), die nog niet gemaakt is in met name de open teelten. Dit blijkt ook uit de amper verminderde afzet van chemische gewasbeschermingsmiddelen in combinatie met het geringe gebruik van laagrisicomiddelen (figuur 3) en de notie van de CEMP's (Coördinatoren Effect Middelen Pakket) dat gewasbeschermingsknelpunten vooral zijn opgelost als er een chemisch alternatief beschikbaar is. Daarnaast heeft het beleid om functionele agrarische biodiversiteit te stimuleren door het vrijwillig aanleggen van akkerranden niet gewerkt. De milieubelasting van het gebruik van gewasbeschermingsmiddelen in de teelt is tot 2016 toegenomen (PBL, 2019), maar neemt volgens Agrimatie sindsdien af. 
Een aandachtspunt is de hoge nitraatuitspoeling op percelen met bladgewassen op de zandgronden (Bremmer et al., 2019)

\section{Kansen}

Verdere verduurzaming van de teelt door het (nog) verder terugdringen van de emissies van gewasbeschermingsmiddelen en stikstof en het verminderen van het energiegebruik is een kans, in het bijzonder voor de biologische sector. Maar ook andere concepten, zoals kringloop-, natuurinclusieve of regeneratieve landbouw bieden kansen, zowel op biologische als op gangbare bedrijven. De biologische sector is ook vaak een kraamkamer voor milieuvriendelijke teeltmethoden en -technieken, waarvan de gangbare akkerbouw kan profiteren. Een voorbeeld daarvan zijn technieken voor mechanische onkruidbestrijding en niet-kerende grondbewerking, die juist in de biologische sector eerder zijn ontwikkeld door het verbod op herbicidengebruik en de grote aandacht voor bodem en bodemleven. Dergelijke technieken zal de gangbare sector nog hard nodig hebben om de te verwachten beperking van de beschikbaarheid van chemische gewasbeschermingsmiddelen op te vangen (Bremmer et al., 2020).

\section{Bedreigingen}

Geen aanvullingen.

Niet van toepassing: Grote gevolgen van de rechterlijke uitspraak inzake het Programma Aanpak Stikstof en de aanvullende wetgeving.

Voor de akkerbouw speelt dit geen rol. 
(f) Bijdragen tot de bescherming van de biodiversiteit, versterken van ecosysteemdiensten en in stand houden van habitats en landschappen.

SWOT-samenvatting subdoelstelling F Bijdragen aan de bescherming van de biodiversiteit, het versterken van ecosysteemdiensten en in stand houden van leefgebieden en landschappen

\begin{tabular}{|c|c|}
\hline Sterke punten & \\
\hline $\begin{array}{l}\text { - De diversiteit van het Nederlandse landschap door de } \\
\text { ligging in een vruchtbare delta, de variatie in } \\
\text { grondsoorten en de ontginningsgeschiedenis } \\
\text { - Stelsel voor collectief agrarisch natuur- en } \\
\text { landschapsbeheer, waarmee gebiedsgericht aan de slag } \\
\text { wordt gegaan voor biodiversiteit } \\
\text { - Groeiende bereidheid bij boeren om zich in te zetten voor } \\
\text { natuur, ecosysteemdiensten en biodiversiteit } \\
\text { Ontwikkelingen in de keten om biodiversiteit in de } \\
\text { landbouw te belonen }\end{array}$ & $\begin{array}{l}\text { - De zeer zorgelijke toestand van biodiversiteit, } \\
\text { ecosysteemdiensten en landschappen in het landelijk } \\
\text { gebied en het vooralsnog ontbreken van een positieve } \\
\text { trend } \\
\text { - Het beperkte areaal dat onder collectief beheer kan } \\
\text { worden gebracht } \\
\text { - Biodiversiteit maakt vrijwel geen deel uit van de } \\
\text { agrarische bedrijfsvoering, inspanningen voor de } \\
\text { versterking van biodiversiteit worden veelal onvoldoende } \\
\text { door de markt beloond } \\
\text { - Het betalen voor biodiversiteit door de markt en de } \\
\text { consument is nog geen gemeengoed } \\
\text { - Landbouwgrond in Nederland is duur, maatregelen voor } \\
\text { biodiversiteit zijn op bedrijfsniveau alleen aantrekkelijk } \\
\text { als er voldoende beloning tegenover staat }\end{array}$ \\
\hline Kansen & \\
\hline $\begin{array}{l}\text { - Groeiende maatschappelijke en politieke aandacht voor } \\
\text { belang biodiversiteit (zoals onder andere tot uiting komt } \\
\text { in het Deltaplan Biodiversiteitsherstel) } \\
\text { - Toenemende belangstelling bij boeren voor } \\
\text { natuurinclusieve en biologische landbouw } \\
\text { - Streven van de overheid om zones van extensieve } \\
\text { landbouw rondom Natura 2000-gebieden te ontwikkelen } \\
\text { - Ontwikkeling van vergoedingen voor ecosysteemdiensten, } \\
\text { in verschillende vormen van publiek-private } \\
\text { samenwerking } \\
\text { Innovatievermogen door combinatie van kennis en } \\
\text { expertise in de agrifoodsector, met kennis van ecologie en } \\
\text { biodiversiteit } \\
\text { Strokenteelt }\end{array}$ & $\begin{array}{l}\text { - Intensivering agrarisch landgebruik (resulterend in } \\
\text { vermesting, verdroging, verzuring, versnippering) } \\
\text { - Industrialisering, verstedelijking en toename } \\
\text { infrastructuur } \\
\text { - Klimaatverandering } \\
\text { - Energietransitie met aanleg van zonne-akkers en } \\
\text { zonneweiden, evenals biomassagewassen } \\
\text { - Geen consistente registratie van landschapselementen. } \\
\text { Alleen de landschapselementen waar subsidie voor } \\
\text { ontvangen wordt zijn geregistreerd in het perceelsregister } \\
\text { Rvo } \\
\text { - Afname van insecten leidt tot minder natuurlijke } \\
\text { bestuivers voor de landbouw } \\
\text { Ontbreken van integraal beleid voor bodem, mest, } \\
\text { klimaat, biodiversiteit en landschap }\end{array}$ \\
\hline
\end{tabular}

Aan het Agrarisch Natuur- en Landschapsbeheer (ANLb) doen vooral melkveebedrijven mee, omdat de kerngebieden voor een groot deel liggen in weidevogelgebieden. In 2019 was het aantal deelnemende bedrijven toegenomen tot een kleine 10.500, verdeeld over 40 collectieven. Een kleine 90.000 ha viel in de categorie 'open grasland', terwijl minder dan 5.000 ha als 'open akkerland' aangeduid is (BoerenNatuur). Predatie maakte dat 2020 niet een goed broedseizoen was voor alle boerenlandvogels. Gelukkig is er groei te zien in verschillende populaties (BoerenNatuur). De benutting van functionele agrobiodiversiteit neemt toe, onder andere door de toepassing van strokenteelt.

\section{Sterktes}

Geen aanvullingen.

\section{Zwaktes}

De inspanningen voor de versterking van biodiversiteit worden veelal onvoldoende door de markt beloond. De vergoedingen voor agrarisch natuurbeheer (ANLb) zijn gebaseerd op extra kosten en gederfde inkomsten voor de inspanningen. Maar daarmee kunnen ze nog niet concurreren met een hoogsalderend gewas. Bovendien komen alleen agrariërs voor vergoeding in aanmerking met grond in een zogenoemd kerngebied en lidmaatschap van een collectief. Vanuit biodiversiteitsdoelen en gevoeligheden rond staatssteun is dit begrijpelijk, maar daardoor kunnen niet alle gemotiveerde agrariërs meedoen. Maar ook in de markt wordt biodiversiteit onvoldoende beloond. Deelname aan 
een keurmerk zoals 'On the way to PlanetProof' levert biodiversiteitswinst op, maar de beloning van de kosten in de vorm van een meerprijs is zo laag, dat de animo daarvoor in met name de akkerbouw en fruitteelt minimaal is (Bouwmeester, 2020). Veel akkerbouwers moeten hoogsalderende gewassen telen om de hoge productiekosten in Nederland, waaronder de hoge grondkosten, te kunnen betalen. ${ }^{11}$

\section{Kansen}

$\mathrm{Er}$ is een toenemende belangstelling bij boeren voor natuurinclusieve landbouw. Aansprekende voorbeelden en een toegenomen aandacht voor dit thema in onder andere de landbouwbladen zet een deel van hen aan het denken. Deze toegenomen belangstelling en de toegenomen mogelijkheden om begeleiding te ontvangen bij omschakeling naar natuurinclusieve landbouw maakt deze stap gemakkelijker ('ontzorgen' kan een onderdeel zijn van een breder pakket aan maatregelen om gedragsverandering te bevorderen; zie onder andere De Lauwere et al. (2003 en 2017)). Een deel van deze interesse vertaalt zich ook door in een toegenomen belangstelling voor biologische landbouw, omdat in de meerprijs voor biologische producten impliciet ook een beloning zit voor biodiversiteitbevorderende maatregelen. Een ander deel uit zich in belangstelling voor strokenteelt, eventueel zelfs in combinatie met biologische landbouw. Bij het concept 'strokenteelt' is in dit verband met name het streven van belang om gedurende het gehele jaar schuil- en voedselstroken voor insecten en kleine dieren te hebben. Dit doet men door met verschillende gewassen, groenbemesters en grondbedekkers in de verschillende stroken te werken die elkaar op dit punt aanvullen.

In het kader van het stikstofbeleid en de noodzaak om N-depositie in Natura 2000-gebieden te verlagen wordt in verschillende provincies nagedacht over het aanwijzen en vormgeven van zones van extensieve landbouw rondom Natura 2000-gebieden. Daarbij zal vooral het streven zijn het aantal landbouwhuisdieren te beperken, maar mogelijk ontstaan er ook kansen in aan Natura 2000-gebieden grenzende akkerbouwbedrijven. Dit kan een kans zijn voor akkerbouwers die gemotiveerd zijn voor biodiversiteitsverbetering op hun bedrijf (of eventueel op een ander bedrijf als er kavel- of bedrijfsruil nodig is), waarbij uiteraard wel maatregelen nodig zijn om dit mogelijk te maken (Westerink et al., 2018).

\section{Bedreigingen}

In het kader van de noodzakelijke energietransitie worden momenteel diverse zonne-akkers en weiden aangelegd. Voor minder courante percelen is dit een kans om ze rendabel te maken, maar er wordt ook vruchtbare grond uit de landbouwproductie weggehaald voor dergelijke doelen. De vraag naar landbouwgrond is in diverse regio's fors gestegen om daar zonneparken aan te leggen of windmolens te plaatsen. Daardoor worden automatische de vraagprijzen voor reguliere landbouwgrond opgestuwd, wat schaalvergroting en bedrijfsovername extra bemoeilijkt. Ook het telen en verstoken van biomassagewassen beperkt de beschikbaarheid van grond voor reguliere akkerbouwgewassen (nog afgezien van de vraag in hoeverre deze vorm van energieproductie bijdraagt aan een verlaging van de $\mathrm{CO}_{2}$-emissies en aan het verdienmodel van akkerbouwers).

Als het herstel van biodiversiteit in Nederland onvoldoende lukt, is ook een afname van insecten en in het bijzonder van natuurlijke bestuivers te verwachten, die voor de land- en tuinbouw onmisbaar zijn bij zaad- en vruchtzetting. Die dreiging is een extra stimulans om biodiversiteitsherstel ook in 'echte' agrarische regio's serieus te nemen.

Breder over thema's en doelen in deze analyse heen wordt in de agrarische sector een integraal beleid voor bodem, mest, klimaat, biodiversiteit en landschap gemist. Deze factoren vertonen onderling interactie en op het agrarische bedrijf komen ook al deze thema's samen in de bedrijfsvoering. Die bedrijfsvoering moet integraal doordacht zijn om tot een optimale voortbrenging van agrarische producten te komen, waarbij zowel de producten zelf als de teeltwijze volledig voldoet aan de eisen en wensen van beleid, keten en markt. In de sector leeft het gevoel dat genoemde thema's bij LNV als aparte dossiers worden behandeld en dat er te weinig interactie en afstemming tussen die dossiers is, waardoor er conflicterende doelen en regelingen zijn geformuleerd. Veel agrariërs hebben het gevoel

${ }^{11}$ Zelfs bij een rentestand van $2 \%$ bedragen de rentekosten van een ha grond die $€ 100.000$ (in Flevoland worden nog hogere prijzen betaald) heeft gekost, al $€ 2.000$. Van een gemiddeld saldo van $€ 4.000$ (dat is een hoog niveau, dat alleen op bedrijven met hoogsalderende gewassen wordt gehaald) gaat dan al de helft naar de financier van de grond. 
meer aan biodiversiteit, klimaat en landschap te kunnen bijdragen als de vergoedingen daarvoor voldoende zijn. Maar doordat er belemmeringen zijn op het gebied van bodem (hoge grondprijzen, zowel koop- als pachtprijzen, vergroeningsregels) en bemesting (krappe bemestingsnormen, beperking van uitrijperiodes) raken sommige agrariërs gedemotiveerd om aan de andere drie thema's bij te dragen. De sector heeft dus behoefte aan een integraal beleid, waarin de verschillende thema's en doelen goed op elkaar aansluiten en elkaar versterken, zonder interne tegenstrijdigheden en voor langere tijd min of meer vast, zodat de hiervoor benodigde aanpassingen en investeringen ook over langere periode rendement kunnen opleveren. 


\subsection{Referenties}

Berkhout, Petra, Jakob Jager en Bert Smit (2019). Inkomenseffecten van de GLB-aanpassingen per 2020; Een quick scan. Wageningen, Wageningen Economic Research, Rapport 2019-114

Berkhout, P. en R. Bergevoet (redactie), A. Beldman, J. Benninga, M. Benus, N. Bondt, Amber ten Brummelhuis (tijdlijnen), S. van den Burg, P. van Dalfsen, Y. Dijkxhoorn, M. Groot, P. van Horne, R. Hoste, J. Jager, B. Janssens, A. Jellema (tijdlijnen), H. Kortstee, H. van der Meulen, A. Mol, E. Poot, L. Puister-Jansen, P. Ravensbergen, B. Smit, R. Stokkers (2020). De impact van de coronacrisis op het Nederlandse agrocomplex. Wageningen Economic Research rapport 2020-088. https://edepot.wur. nl/536350

Bijman, J., C. Iliopoulos, K.J. Poppe, C. Gijselinckx, K. Hagedorn, M. Hanisch, G.W.J. Hendrikse, R. Kühl, P. Ollila, P. Pyykkönen, G. van der Sangen (2012). Support for Farmers' Cooperatives; Final Report for the European Commission. https://research.wur.nl/en/publications/support-forfarmers-cooperatives-final-report

Bouwmeester, R. (2020). LTO Akkerbouw en NFO nemen afstand van PlanetProof. Nieuwe Oogst 7 november 2020. www. nieuweoogst.nl/nieuws/2020/11/07/lto-akkerbouw-en-nfo-nemen-afstandvan-planetproof.

Bremmer, Johan, Bas Janssens, Marc Ruijs, Jan Benninga, Robert Stokkers, Gerben Splinter, Pepijn Smit, Linda Puister-Jansen (2019). Plantaardige ketens in beeld. https://doi.org/10.18174/494597

Bremmer, J., A-C. Hoes, C. de Lauwere, B. Smit (2020). Van kwetsbaar naar weerbaar; Het Uitvoeringsprogramma Toekomstvisie Gewasbescherming 2030 belicht vanuit transitietheorie. Wageningen, Wageningen Economic Research, Rapport 2020-059, 50 pp. https://edepot.wur.nl/526698.

CLM (2020). Onderzoek naar milieubelasting in suikerbiet voor en na het verbod op neonicotinoïden. Samengevat in Gewasbescherming, 52, 1 (februari 2021).

Dekking, A., J-E. Jansma, B. Janssens en B. Smit (2020). Biologische landbouw in Flevoland; Omvang en productstromen. Wageningen Research, rapport WPR-822. https://edepot.wur.nl/511396

Galen, M. van, en R.W. van der Meer (2020). Innovatie in de land- en tuinbouw 2019. Wageningen Economic Research Rapport 2020-126. https://edepot.wur.nl/535583

Harmsen, P., S. Lips, H. Bos (Wageningen UR-Food and Biobased Research), B. Smit, S. van Berkum, J. Helming en R. Jongeneel (LEI Wageningen UR) (2014). Suiker als grondstof voor de Nederlandse chemische industrie; gewassen, proces, beleid. Wageningen, FBR-rapport Nummer 1494. http://edepot.wur.nl/312696.

Janssens, B., R. van der Meer en B. Smit (2020). Gevolgen van de coronacrisis voor de aardappelsector. Wageningen Economic Research factsheet 2020-039f.

https://edepot.wur.nl/523096.

Jongeneel, R., W. Baltussen, S. van Berkum en K. Poppe (2020). Juiste en eerlijke prijzen voor voedsel. Wageningen Economic Research, White paper 2020-009. https://edepot.wur.nl/513322.

Jukema, G.D., P. Ramaekers en P. Berkhout (Red.) (2021). De Nederlandse agrarische sector in internationaal verband - editie 2021. Wageningen/Heerlen/Den Haag, Wageningen Economic Research en Centraal Bureau voor de Statistiek, Rapport 2021-001.

https://doi.org/10.18174/538688

Lauwere, de, C.C., A.J. de Buck, A.B. Smit, J.S. Buurma, H. Drost, H. Prins en L.W. Theuws (2003). Omschakelen naar geïntegreerde of biologische teelt. Motieven, voorwaarden, risico's, mogelijke oplossingsrichtingen en de rol van de ondernemer. Wageningen, Rapport 2003-02, Wageningen UR, 89 pp. http://edepot.wur.nl/24233.

Lauwere, de, C., E. Oosterkamp, B. Smit, M. Vrolijk en A. Breukers (2017). Beleidsinstrumenten voor energieneutrale en klimaatvriendelijke agrosectoren; Zoektocht naar de optimale instrumentenmix. Wageningen, Wageningen Economic Research, Rapport 2017-108. https://edepot.wur.nl/426235.

Meulen, van der, Harold, Jakob Jager, Daniel de Jong, Rob Stokkers, Gabe Venema en Marcel Vijn (2019). Kijk op multifunctionele landbouw; Omzet 2007-2018. Wageningen, Wageningen University \& Research, Rapport 2019-054. https://doi.org/10.18174/476198

Meulen, H.A.B. van der, J.H. Wisman, J.H. Jager, G.D. Jukema en R.W. van der Meer (2020). Investeringsniveau duurzame productiemiddelen; Duurzaamheidsindicator (DP01) in de Rijksbegroting 2021. Wageningen, Wageningen Economic Research, Rapport 2020-103 
PBL (Planbureau voor de Leefomgeving) (2019). Geïntegreerde gewasbescherming nader beschouwd. Tussenevaluatie van de nota Gezonde groei, duurzame oogst. PBL-publicatienummer: 3549

RVO (Rijksdienst voor Ondernemend Nederland) (2020). Convenant Schone en Zuinige Agrosectoren 2008-2020. Eindrapportage. Via:

https://www.rijksoverheid.nl/documenten/kamerstukken/2020/12/18/eindrapportage-convenantschone-en-zuinige-agrosectoren-2008---2020

Silvis, H. (LEI), K. Smekens (ECN), D. Verhoog (LEI), B. Daniëls (ECN), m.m.v. B. Smit, G. Doornewaard, N. van der Velden, A. Wisman (LEI), J. van den Briel en J. Oldenburger (Probos) (2015). Opties voor energie-neutrale agrosectoren in 2025. Wageningen, LEI Wageningen UR, LEI Report 2015-108. http://edepot.wur.nl/362115

Smit, A.B. en S.R.M. Janssens (2016). Reststromen suikerketen. LEI Wageningen UR (University \& Research centre), Factsheet 2016-013b, 12 pp. http://edepot.wur.nl/368098.

Smit, A.B., A.C.G. Beldman, J.A.A.M. Verstegen, G.S. Splinter, A. Bikker, K. de Grip, P.L. de Wolf (PPO, onderdeel van Wageningen UR), C.C. de Lauwere en O. Hietbrink (2013). Versterking van ketenondernemerschap in de agrosector; Advies ten behoeve van Partners voor Ondernemerschap. Den Haag, LEI, Rapport 2013-017. http://edepot.wur.nl/262623.

Smit, A.B., J.H. Jager, R.W. van der Meer, D. Verhoog, T.A. Vogelzang, M. Dolman (allen Wageningen Economic Research), H. Kros (Wageningen Environmental Research) en Th. Van der Linden (Kadaster) (2017). De Noord-Nederlandse agrosector en agrocluster in beeld. Wageningen Economic Research, Rapport 2017-033 en Bijlagen - Kaarten en Management Samenvatting

Westerink, J. (Wageningen Environmental Research), B. Smit, M. Dijkshoorn, N. Polman en T. Vogelzang (Wageningen Economic Research) (2018). Boeren in Beweging; Hoe boeren afwegingen maken over natuurinclusieve landbouw en hoe anderen hen kunnen helpen. Wageningen UR, interactieve pdf. https://www.wur.nl/upload_mm/9/f/2/7ba976aa-0961-4bff8fe3-5de58daabd5a_DEF\%20KOM_Boeren\%20in\%20Beweging.pdf 


\subsection{Bijlage Indicatoren}

N.B. Alle data zijn op basis van Eurostat of nationale data als in Eurostat geen gegevens beschikbaar waren op deelsectorniveau.

Indicatoren C.12 tot en met C.34

Tabel C.12 Aantal bedrijven naar bedrijfsgrootte in ha en standaardopbrengst (SO)

\begin{tabular}{|c|c|c|c|}
\hline & \multicolumn{3}{|c|}{ Akkerbouwbedrijven } \\
\hline & 2010 & 2015 & 2020 \\
\hline \multicolumn{4}{|c|}{ Aantal bedrijven naar omvang in ha } \\
\hline$<1$ ha & 8 & 14 & 7 \\
\hline $1-5$ ha & 1.299 & 1.667 & 1.051 \\
\hline 5-10 ha & 2.168 & 2.317 & 1.877 \\
\hline $10-30$ ha & 3.590 & 3.575 & 3.604 \\
\hline $30-50$ ha & 1.806 & 1.793 & 1.708 \\
\hline$>50$ ha & 3.091 & 3.027 & 2.970 \\
\hline Totaal & 11.962 & 12.393 & 11.217 \\
\hline \multicolumn{4}{|c|}{ Aantal bedrijven naar omvang in standaardopbrengst (SO) } \\
\hline SO: $3.000-25.000$ euro & 4.917 & 4.998 & 3.506 \\
\hline SO: $25.000-100.000$ euro & 3.220 & 3.412 & 3.121 \\
\hline SO: $100.000-250.000$ euro & 2.409 & 2.316 & 2.364 \\
\hline SO: $250.000-500.000$ euro & 1.057 & 1.122 & 1.336 \\
\hline SO: $500.000-1.000 .000$ euro & 294 & 430 & 643 \\
\hline SO: $1.000 .000-1.500 .000$ euro & 50 & 89 & 170 \\
\hline SO: $1.500 .000-3.000 .000$ euro & 12 & 24 & 72 \\
\hline SO: $>3.000 .000$ euro & 2 & 2 & 5 \\
\hline Totaal & 7.044 & 7.395 & 7.711 \\
\hline \multicolumn{4}{|c|}{ Gemiddelde bedrijfsgrootte in ha en So } \\
\hline ha & 38,5 & 37,6 & 41,6 \\
\hline SO (x 1.000 euro) & 106 & 116 & 167 \\
\hline \multicolumn{4}{|l|}{ idem $2010=100$} \\
\hline $\mathrm{Ha}$ & 100 & 98 & 108 \\
\hline SO (x 1.000 euro) & 100 & 110 & 158 \\
\hline
\end{tabular}

Tabel C.13a Arbeidsinzet - in arbeidsjaareenheden

\begin{tabular}{|c|c|c|c|}
\hline Akkerbouwbedrijven & 2010 & 2015 & 2020 \\
\hline Man & 11.435 & 4.549 & 5.564 \\
\hline Niet-reguliere arbeidsinzet & 706 & 863 & 950 \\
\hline
\end{tabular}

Tabel C.13b Arbeidsinzet: aantal arbeidsjaareenheden naar gezinsarbeid en vreemde arbeid

\begin{tabular}{lrrr} 
Akkerbouwbedrijven & 2010 & 2015 & 2020 \\
Gezin & 12.547 & 13.272 & 13.482 \\
\hline Niet-gezin & 2.626 & 3.012 & 3.887 \\
\hline
\end{tabular}


Tabel C.14 Leeftijdsopbouw agrarische bedrijfshoofden

\begin{tabular}{lrrr} 
Akkerbouwbedrijven & 2010 & 2015 & 871 \\
$<40$ jaar (A) & 953 & 2020 \\
$>55$ jaar (B) & 5.970 & 6.780 & 6.774 \\
\hline Totaal & 11.962 & 12.393 & 11.217 \\
\hline ratio (A/B) & 16 & 13 & 12 \\
\hline
\end{tabular}

Tabel C.16 Bedrijfsopvolging

\begin{tabular}{lrrr} 
Akkerbouwbedrijven & 2012 & 2016 & 2020 \\
aantal bedrijven met een opvolger & 2.581 & 2.629 & 2.918 \\
\hline aantal bedrijven met een bedrijfshoofd $>51$ jaar & 7.661 & 7.161 \\
\hline aantal bedrijven met een bedrijfshoofd $<51$ jaar & 3.664 & 7.893 \\
\hline aandeel bedrijven met een opvolger & 34 & 2.981 & 37
\end{tabular}

Tabel C.17 Areaal Akkerbouw (ha) op gespecialiseerde Akkerbouwbedrijven

\begin{tabular}{lrrr} 
& 2010 & 2015 & 2020 \\
\hline Akkerbouwbedrijven & 389.988 & 371.856 & 376.735 \\
\hline
\end{tabular}

C18-C23: niet beschikbaar

Tabel C.24 Netto toegevoegde waarde per aje (in euro)

\begin{tabular}{lrrr} 
& 2010 & 2015 & 2019 \\
\hline Akkerbouwbedrijven (in euro) & 113.310 & 80.885 & 67.567 \\
\hline Index $(\mathbf{2 0 1 0}=\mathbf{1 0 0})$ & 100 & 71 \\
\hline
\end{tabular}

Tabel C.25 Inkomen uit bedrijf per oaje (in euro)

\begin{tabular}{lrrr} 
& 2010 & 2015 & 2019 \\
\hline Akkerbouwbedrijven (in euro) & 95.342 & 68.131 & 41.593 \\
\hline Index $(\mathbf{2 0 1 0}=\mathbf{1 0 0})$ & 100 & 71
\end{tabular}

C. 26 niet beschikbaar.

C.27 niet beschikbaar.

C.28 niet beschikbaar.

C.29 niet beschikbaar.

C.30 Handel.

Op het niveau van de akkerbouw zijn niet direct gegevens beschikbaar. Hooguit zijn gegevens opvraagbaar voor aardappelen, granen of suikerbieten of, in veel gevallen, van verwerkte producten zoals frites, graanbereidingen, suiker of zetmeel.

C.31 niet beschikbaar. 
Tabel C.32 Areaal biologische landbouw en aandeel areaal biologische landbouw op totale areaal akkerbouwsector

\begin{tabular}{|c|c|c|c|c|c|c|}
\hline Aantal hectares & 2015 & 2016 & 2017 & 2018 & 2019 & 2020 \\
\hline $\begin{array}{l}\text { Totaal areaal biologisch plus in } \\
\text { omschakeling }\end{array}$ & 7.034 & 8.164 & 9.206 & 10.053 & 11.642 & 12.557 \\
\hline Areaal in omschakeling & 739 & 1.291 & 1.792 & 2.175 & 2.474 & 1.770 \\
\hline Totale areaal akkerbouw & 499.933 & 471.130 & 449.875 & 457.691 & 460.069 & 495.197 \\
\hline $\begin{array}{l}\text { Totaal areaal biologisch plus in } \\
\text { omschakeling }\end{array}$ & 1,4 & 1,7 & 2,0 & 2,2 & 2,5 & 2,5 \\
\hline Areaal biologisch & 1,3 & 1,5 & 1,6 & 1,7 & 2,0 & 2,2 \\
\hline Areaal in omschakeling & 0,1 & 0,3 & 0,4 & 0,5 & 0,5 & 0,4 \\
\hline
\end{tabular}

Tabel C.33 Intensieve landbouw, aandeel areaal met een hoge inputintensiteit (grond met een totale input van veevoer, kunstmest en gewasbeschermingsmiddelen van meer dan $€ 350$ per ha)

\begin{tabular}{lrr} 
& 2010 & 2015 \\
Akkerbouwbedrijven & 69 & 2019 \\
\hline
\end{tabular}

\section{C.34 niet beschikbaar.}

Indicatoren C.35-C.48

C.35 niet beschikbaar naar type bedrijf

C.36 niet beschikbaar naar type bedrijf

C.38 niet beschikbaar naar type bedrijf

C. 40 niet beschikbaar naar type bedrijf

C.41 niet beschikbaar naar type bedrijf

C. 42 niet beschikbaar naar type bedrijf

C.43 niet beschikbaar naar type bedrijf

C.44 niet beschikbaar naar type bedrijf

C.45 niet beschikbaar naar type bedrijf

C.46 niet relevant voor de akkerbouw

C.47 niet relevant voor de akkerbouw

Tabel C.48 Afzet van pesticiden (1.000 ton werkzame stof)

\begin{tabular}{lrrr} 
& 2010 & 2015 & 2019 \\
Akkerbouwbedrijven & 3,84 & 3,85 & 4,08 \\
\hline
\end{tabular}




\section{SWOT-analyse deelsector melkvee}

Alfons Beldman

N.B. deze analyse moet worden gelezen in samenhang met de SWOT-analyse op het niveau van de landbouw als geheel. Onderhavige analyse verbijzondert de SWOT-analyse waar nodig naar de deelsector in kwestie.

\subsection{Algemene beschrijving van de sector melkvee}

Korte beschrijving van de sector ${ }^{12}$

De melkveehouderij heeft een lange historie in Nederland. Met name in het westen en delen van het noorden van het land wordt al eeuwenlang melkvee gehouden omdat de natte veengronden zich alleen lenen voor grasland en omdat dit met melkvee in boter en kaas kon worden omgezet. In andere regio's werd melkvee oorspronkelijk op gemengde bedrijven gehouden. In de loop van de tijd zijn de bedrijven steeds meer gespecialiseerd. De sector bestaat nu hoofdzakelijk uit gespecialiseerde melkveebedrijven, in 202014.572 met gemiddeld circa 104 melkkoeien per bedrijf en gemiddeld circa 58 ha grond in gebruik hoofdzakelijk voor gras en een deel voor snijmais (tabel C.12). Het aantal bedrijven neemt gestaag af. Zie ook de figuur hieronder. De meeste bedrijven zijn familiebedrijven, de arbeid wordt grotendeels door het gezin geleverd (tabel C.13b). De totale omvang van arbeid neemt slechts beperkt af (tabel C.13b).

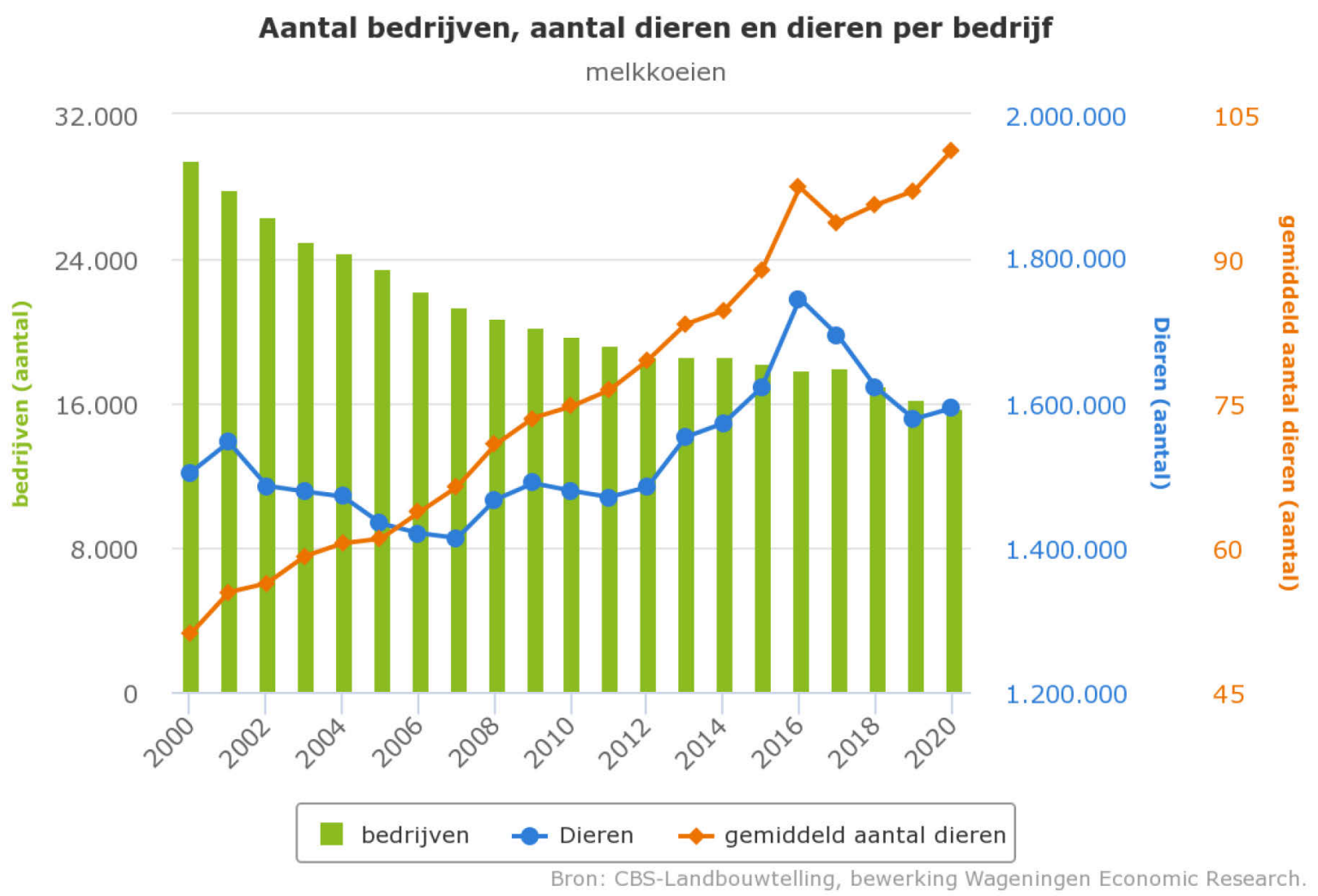

Figuur 1 Aantal bedrijven met melkvee, areaal en areaal per bedrijf. N.B. cijfers kunnen afwijken van in de tekst genoemde, omdat hier alle bedrijven met melkvee worden meegenomen, niet enkel de gespecialiseerde melkveebedrijven

\footnotetext{
${ }^{12}$ Bronnen: Peet et al. (2019); Beldman et al. (2020): https://edepot.wur.nl/532156; Zuivel in cijfers.
} 
In zijn totaliteit heeft de melkveehouderij circa $60 \%$ van de agrarische grond in Nederland in gebruik. De belangrijkste melkveehouderij provincies in Nederland zijn Friesland, Overijssel, Gelderland en Noord-Brabant met elk een productie van meer dan 2 miljard kg melk.

In totaal is er in Nederland in 201914 miljard kg melk verwerkt door in totaal 25 ondernemingen met in totaal 53 productielocaties. Vijf van deze ondernemingen zijn coöperaties, waaronder de grootste zuivelverwerker in Nederland FrieslandCampina. In de aanloop naar het eind van de melkquotering is een aantal nieuwe private zuivelverwerkende ondernemingen actief geworden in Nederland. Het beeld is dat in ieder geval een deel van de leveranciers die naar deze bedrijven zijn overgestapt afkomstig zijn van coöperaties. Een deel van de zuivelverwerkers is eigendom van of werkt nauw samen met buitenlandse zuivelbedrijven. Het belangrijkste product, met circa $56 \%$ van de melk, is kaas. De totale kaasproductie was in 2019 ongeveer 891 duizend ton. Melkpoeder is het volgende product in de rij, met circa $15 \%$. Een belangrijk deel (65\%) van de zuivelproducten wordt geëxporteerd, de totale waarde van de geëxporteerde zuivel van Nederlandse oorsprong bedroeg in $2019 € 6,2$ miljard. Circa driekwart van deze uitvoer is bestemd voor Europa en daar binnen met name voor België, Duitsland en Frankrijk (samen 70\%). Er zijn geen specifieke cijfers over de afzet van biologische zuivel beschikbaar. Eko Holland, een coöperatie van 180 Nederlandse biologische melkveehouders geeft aan dat de biologische zuivel grotendeels in Nederland wordt afgezet.

Het totale areaal voedergewassen op melkveebedrijven is tussen 2015 en 2020 licht gedaald van bijna 828.000 ha naar bijna 816.000 ha (tabel C.17).

\section{Bedrijfstypen}

De meeste melkveebedrijven telen het ruwvoer op het eigen bedrijf. Het areaal voedergewassen op melkveebedrijven bestaat hoofdzakelijk uit grasland $(86 \%)$ en snijmais. De bedrijven in het Noordwesten ${ }^{13}$ (hoofdzakelijk klei en veengrond) zijn gemiddeld wat extensiever (1,8 melkkoe per ha) en kennen een groter aandeel grasland dan de bedrijven uit het Zuidoosten die voornamelijk op zandgrond zijn gelegen (2,0 melkkoe per ha). $83 \%$ van de bedrijven past een vorm van weidegang toe, circa $75 \%$ weidt de koeien minimaal 120 dagen en 6 uur. De bedrijven in het Noordwesten passen gemiddeld meer weidegang toe dan die in het Zuidoosten. Het aandeel bedrijven met een bedrijfshoofd ouder dan 55 jaar was 45\% in 2020, dit lag op ruimt 30\% in 2010 (tabel C.14). Het aandeel bedrijven met opvolger is vrij stabiel en lag in 2020 op 58\% (tabel C.16).

\section{Aandeel biologisch ${ }^{14}$}

Het aandeel biologische melkveebedrijven bedraagt ongeveer 3,1\%. Op deze bedrijven wordt ongeveer 2,5\% van het aantal koeien gehouden. Dit betekent dat de biologische bedrijven in aantal koeien gemiddeld kleiner in omvang zijn dan de gangbare bedrijven. Qua oppervlakte is het aandeel $3,7 \%$ en nog eens $0,4 \%$ in omschakeling (tabel C.32). Het aantal biologische melkveebedrijven neemt geleidelijk aan toe, van 334 in 2011 naar 471 in 2018 (CBS).

\section{Duurzaamheid}

In aanloop van de afschaffing van de melkquotering heeft de sector (NZO en LTO) Duurzame Zuivelketen ${ }^{15}$ opgericht. Binnen Duurzame Zuivelketen is een aantal doelen opgesteld rond vier thema's (klimaat en energie, weidegang, diergezondheid en dierenwelzijn en biodiversiteit en milieu). Per thema zijn doelen geformuleerd op de volgende subthema's

- Klimaatneutraal ontwikkelen: reductie broeikasgasemissies (klimaatneutrale groei en 20\% reductie ten opzichte van 1990), verhogen energie-efficiëntie, verhogen duurzame energieproductie

- Continu verbeteren diergezondheid en dierenwelzijn: antibioticagebruik, verlengen levensduur en ontwikkelen van een monitoringssystematiek voor dierenwelzijn.

- Behoud weidegang:

- Behoud van biodiversiteit en milieu: 100\% verantwoorde soja, fosfaatexcretie en ammoniakemissie binnen de milieuplafonds en de ontwikkeling van een monitoringssystematiek voor biodiversiteit.

\footnotetext{
13 Zuid Holland, Utrecht, Noord-Holland, Friesland, Groningen.

${ }^{14}$ Bron: https://www.agrimatie.nl/ThemaResultaat.aspx?subpubID=2232\&themaID =2267\&indicatorID =2106

15 www.Duurzamezuivelketen.nl
} 
Jaarlijks wordt een zogenaamde sectorrapportage ${ }^{16}$ gemaakt waarin wordt aangegeven hoe de sector presteert ten opzichte van de afgesproken doelen. Onderstaande tabel laat de samenvatting van het resultaat zien voor het kalenderjaar 2019. In 2019 is voor alle indicatoren vooruitgang geboekt ten opzicht van 2018. Voor een aantal indicatoren is het doel van 2020 gehaald, voor een aantal andere indicatoren (klimaat, levensduur en ammoniak) nog niet. Vrij recent zijn nieuwe doelen geformuleerd voor 2030.

\begin{tabular}{|c|c|c|c|}
\hline Thema & Subthema & $\begin{array}{l}\text { Stand van } \\
\text { zaken } \\
\text { doelrealisatie a) }\end{array}$ & $\begin{array}{l}\text { Voortgang } \\
\text { ten opzichte } \\
\text { van } 2018 \text { b) }\end{array}$ \\
\hline \multirow[t]{4}{*}{$\begin{array}{l}\text { Klimaatneutraal } \\
\text { ontwikkelen }\end{array}$} & $\begin{array}{l}\text { Broeikasgassen } \\
\text { Klimaatneutrale } \\
\text { groei }\end{array}$ & $\begin{array}{l}\text { Emissie Zuivelketen: } \\
\text { (Mton } \mathrm{CO}_{2} \text {-eq.) }\end{array}$ & \\
\hline & $\begin{array}{l}\text { Broeikasgassen } \\
20 \% \text { reductie ten } \\
\text { opzichte van } 1990\end{array}$ & $\begin{array}{l}\text { Emissie Zuivelketen: } \\
\text { (Mton } \mathrm{CO}_{2} \text {-eq.) }\end{array}$ & \\
\hline & Energie-efficiëntie & $\begin{array}{l}\text { Primair brandstof- } \\
\text { verbruik zuivelketen } \\
\left(\mathrm{m}^{3} \text { a.e. per } 1.000 \mathrm{~kg}\right. \\
\text { melk) }\end{array}$ & \\
\hline & $\begin{array}{l}\text { Duurzame energie- } \\
\text { productie }\end{array}$ & $\begin{array}{l}\text { Productie duurzame } \\
\text { energie (\% van } \\
\text { consumptie) }\end{array}$ & \\
\hline \multirow{3}{*}{$\begin{array}{l}\text { Continu } \\
\text { verbeteren } \\
\text { diergezondheid } \\
\text { en dierenwelzijn }\end{array}$} & Antibiotica & $\begin{array}{l}\text { Aandeel bedrijven } \\
\text { onder de SDa- } \\
\text { actiewaarde }\end{array}$ & \\
\hline & Levensduur & $\begin{array}{l}\text { Leeftijd bij afvoer } \\
\text { melkkoeien }\end{array}$ & \\
\hline & Dierenwelzijn & $\begin{array}{l}\text { Ontwikkeling monitoringssystematiek } \\
\text { (uiterlijk 2017) }\end{array}$ & $\begin{array}{c}\text { Systematiek } \\
\text { gereed. Doelen } \\
\text { nog niet } \\
\text { vastgesteld }\end{array}$ \\
\hline $\begin{array}{l}\text { Behoud } \\
\text { weidegang }\end{array}$ & Weidegang & $\begin{array}{l}\text { Aandeel bedrijven met } \\
\text { weidegang }(\%)\end{array}$ & \\
\hline \multirow{4}{*}{$\begin{array}{l}\text { Behoud } \\
\text { biodiversiteit en } \\
\text { milieu }\end{array}$} & Verantwoorde soja & $\begin{array}{l}\text { Aandeel duurzame } \\
\text { soja }(\%)\end{array}$ & \\
\hline & Mineralen & $\begin{array}{l}\text { Fosfaatexcretie } \\
\text { melkveestapel } \\
\text { (miljoen } \mathrm{kg} \text { ) }\end{array}$ & \\
\hline & & $\begin{array}{l}\text { Ammoniakemissie } \\
\text { melkveestapel } \\
\text { (miljoen } \mathrm{kg} \text { ) }\end{array}$ & $\sqrt{c)}$ \\
\hline & Biodiversiteit & $\begin{array}{c}\text { Ontwikkeling monitoringssystematiek } \\
\text { (uiterlijk 2017) }\end{array}$ & $\begin{array}{c}\text { Systematiek } \\
\text { gereed op } \\
\text { individueel } \\
\text { bedrijfsniveau, } \\
\text { niet op } \\
\text { sectorniveau. } \\
\text { Doelen nog niet } \\
\text { vastgesteld }\end{array}$ \\
\hline \multicolumn{4}{|c|}{$\begin{array}{l}\text { ! betekent doelrealisatie vraagt forse extra inspanning; b) } \sqrt{ } \text { betekent resultaat } 2019 \text { verbeterd ten } \\
\text { opzichte van } 2018 \text { of resultaat } 2019 \text { op gewenst niveau, } \sqrt{ } \text { betekent resultaat } 2019 \text { vrijwel gelijk aan }\end{array}$} \\
\hline
\end{tabular}

Dierenwelzijn is meegenomen in de aparte analyse van Galama et al. (2020) 'Enkele maatschappelijke thema's van landbouw en voedsel nader bepaald. Een aanvullende analyse op de houtskool-SWOT'

16 https://edepot.wur.nl/538950 
In een studie over de verwachte ontwikkeling van de melkveehouderij richting 2030 is ook gekeken in hoeverre de melkveehouderij dan binnen de milieuplafonds bleef. Voor fosfaat was dit het geval (dat was ook een uitgangspunt van de studie). In de studie werd niet specifiek rekening gehouden met maatregelen die op bedrijfsniveau kunnen worden doorgevoerd om broeikasgasemissies en stikstofemissies terug te dringen. Uit het resultaat blijkt dat het stikstofplafond haalbaar lijkt en dat ook de afspraak voor de reductie van methaanemissie uit het klimaatakkoord binnen handbereik lijkt. Dit geldt echter duidelijk niet voor ammoniakemissie.

Biologische melkveebedrijven scoren op een aantal duurzaamheidskenmerken beter dan gangbare melkveebedrijven (agrimatie.nl). Dit geldt bijvoorbeeld voor levensduur van de melkkoeien, het stikstofbodemoverschot, de ammoniakemissie en het gebruik van gewasbeschermingsmiddelen. Ook beweiden biologische melkveebedrijven meer dan gangbare bedrijven. Voor klimaat en energie scoren de biologische melkveebedrijven gemiddeld slechter. 


\section{$2.2 \quad$ WOT-analyse per deelsector en per specifieke doelstelling (vergelijk H3 van de Houtskool SWOT)}

\section{(a) Bieden van steun met het oog op een leefbaar landbouwinkomen en veerkracht in de hele Unie om de voedselzekerheid te vergroten;}

SWOT-samenvatting subdoelstelling A Bieden van steun met het oog op een leefbaar landbouwinkomen en veerkracht in de hele Europese Unie om de voedselzekerheid te vergroten

- Pterke punten
- Opleidingsniveau, kennisnetwerk
- Innovatief vermogen
- Veerkracht
- Hoge productiviteit per ha en per dier
- Sterke vermogenspositie maakt bedrijven weerbaar
- Gezinsbedrijf dominant
- Hoge aandeel berekende kosten vergroot weerbaarheid
- Sector is goed georganiseerd

- Sector is goed georganiseerd

\section{Zwakke punten}

- Hoge kostprijs als gevolg van dure grond, dure stalsystemen en arbeid

- Inkomens landbouw lager ten opzichte van vergelijkbaar werk buiten de landbouw en andere landbouwsectoren

- Merendeel van de huidige melkveebedrijven realiseert geen marktconforme beloning voor de inzet van eigen arbeid en kapitaal

- Melkprijs is over een lange periode gezien niet gestegen, schaalvergroting heeft stijging kostprijs nauwelijks kunnen compenseren

- Werken buiten de landbouw is financieel aantrekkelijker

- Sterke vermogenspositie bemoeilijkt bedrijfsovernames

- Rendement op eigen vermogen en arbeid lager dan in sectoren buiten de landbouw

- Markt voor een deel van de bedrijven in alternatieve bedrijfsvormen/verdienmodellen (korte ketens, multifunctionele landbouw)

- Vraag naar publieke diensten (nieuw GLB of andere bronnen)

- Sterke verstedelijking van het Nederlandse platteland geeft kansen voor directe verbindingen met de stad via het leveren van producten en diensten

- Inzet Deltaplan Biodiversiteitsherstel gericht op het creëren van nieuwe verdienmodellen door middel van gestapelde beloningen

- Inzet Platform Multifunctionele Landbouw om knelpunten in ontwikkeling multifunctionele landbouw weg te nemen en ontwikkelruimte te creëren

\section{Bedreigingen}

- Inkomensondersteunende en stabiliserende werking toeslagen neemt verder af

- Bedrijfsovername niet eenvoudig door kapitaalintensiteit bedrijven

- Na bedrijfsovername is aantrekken vreemd vermogen lastig gegeven zware financiering

- Hoge grondprijs belemmert extensivering

- Financieringslasten bij overname

- Aantrekkingskracht werk buiten de sector, jonge boeren kiezen bewust voor baan buiten de landbouw (is deels ook een kans omdat het ruimte schept voor andere bedrijven om door te groeien)

- Extra duurzaamheidseisen, bijvoorbeeld rond stikstof of klimaat kunnen tot aanvullende kosten leiden

- Aandacht voor het vergroten van veerkracht

- Subsidiemodule agrarische bedrijfsadvisering en educatie (SABE-regeling)

\section{Sterke punten}

De sterke vermogenspositie is met name gebaseerd op het feit dat melkveehouders ongeveer twee derde van de grond die ze in gebruik hebben in eigendom hebben. Rond het einde van de mekquotering heeft een aantal bedrijven behoorlijk geïnvesteerd in uitbreiding. Een deel van deze bedrijven zit na het fosfaatreductieplan en de invoering van de fosfaatrechten met nieuwe stallen met bijbehorende financiering die niet volledig bezet zijn en dus met relatief zware financieringslasten.

Het gezinsbedrijf is de dominante bedrijfsvorm. Kracht van het gezinsbedrijf is de flexibiliteit. In de kostprijs van melkveehouderij spelen berekende kosten voor eigen arbeid en eigen vermogen een belangrijke rol. In tijden dat het minder goed gaat wordt genoegen genomen met een lagere vergoeding op het eigen vermogen en eigen arbeid. In de praktijk betekent dit dat privé-uitgaven worden teruggebracht om een zo'n periode door te komen.

De melkveehouderij sector is goed georganiseerd. Dit is op veel terreinen zichtbaar. Historisch bij voorbeeld in het grote aantal coöperaties dat actief is in de sector zowel in de zuivelverwerking als in 
de toeleverende industrie (fokkerij, mengvoerbedrijven). Recenter is dit is onder andere zichtbaar in de data-uitwisseling en ontsluiting op branche niveau (ZuivelNL). Dit maakt het mogelijk om snel kengetallen te ontwikkelen en toe te passen, ook voor opkomende thema's (bijvoorbeeld Kringloopwijzer). Het innovatief vermogen is vergelijkbaar met andere veehouderij sectoren (innovatiemonitor). De sector heeft een eigen innovatieorganisatie Courage.

\section{Zwakke punten}

Het agrarisch factor inkomen van melkveebedrijven is de laatste 10 jaar aan schommelingen onderhevig, maar lijkt gemiddeld vrij stabiel. Het inkomen per onbetaalde arbeidsjaareenheid is over de laatste 10 jaar gemiddeld het laagste van alle landbouwsectoren en vertoont bovendien behoorlijk grote schommelingen in deze periode van circa $€ 14.600$ in 2016 tot iets meer dan $€ 63.000$ in 2017. Het gemiddelde inkomen van 2010 tot en met 2014 was iets meer dan $€ 35.000$ over de periode van 2015 tot en met 2019 was dit $€ 37.750$ per onbetaalde arbeidsjaareenheid. De melkprijs is over een langere periode gezien vrijwel gelijk gebleven. De gemiddelde fabrieksmelkprijs was over 5 jaar tussen 1990 en $1994 € 35,59$ per $100 \mathrm{~kg}$ melk en van 2015 tot en met 2019 gemiddeld $€ 36,08$ per $100 \mathrm{~kg}$ melk. In de tussenliggende perioden variëren de 5-jarige gemiddelden van $€ 33,20$ tot 38,35. De schaalvergroting die heeft plaats gevonden is gezien de gelijkblijvende inkomens net voldoende om de kostenstijging op te vangen. Het is overigens wel zo dat de grotere melkveebedrijven gemiddeld een hoger inkomen realiseren dan de kleinere melkveebedrijven.

Biologische melkveebedrijven haalden gemiddeld over de periode 2011-2020 een iets lager inkomen per onbetaalde arbeidsjaareenheid in vergelijking met de gangbare bedrijven. Gemiddeld kwamen de biologische bedrijven uit $€ 36.330$, dit is $€ 1.420$ lager dan het inkomen op gangbare bedrijven (agrimatie. $\mathrm{nl}$ ).

Niet van toepassing: De zwakke onderhandelingspositie in de keten is voor de melkveehouderij niet als zwak punt opgenomen omdat een belangrijk deel van de melk via coöperaties wordt verwerkt. De prijsvorming wordt met name bepaald door de exportmarkt.

\section{Kansen}

Voor een deel van de bedrijven zijn er kansen voor korte ketens en multifunctionele landbouw. Corona heeft bij voorbeeld laten zien dat directe afzet naar consumenten is gestegen. Het totale volume dat op deze manier wordt afgezet is beperkt. Circa 96\% van de produceerde melk wordt afgezet via zuivelverwerkers. Van het resterende deel wordt een deel op de melkveebedrijven zelf vervoederd. De afzet van biologische melk ontwikkelt zich langzaam.

In aanvulling op de overige kansen is het Deltaplan Biodiversiteitsherstel opgenomen. Binnen dit deltaplan wordt gewerkt aan het creëren van nieuwe verdienmodellen door middel van gestapelde beloningen. Verbreding en multifunctionele landbouw bieden kansen voor een deel van de melkveebedrijven. Voor directe afzet is het daarbij van belang dat er afzet in de regio is, dus in de nabijheid van stedelijk gebied. De schaalbaarheid van deze verdienmodellen is een belangrijk vraag, er lopen diverse pilots, onder andere rond koolstofvastlegging, maar het is nog niet duidelijk of dit voor veel melkveebedrijven beschikbaar komt. Een belangrijk punt is ook of deze beloningen ook echt geld opleveren of beperkt blijven tot een vergoeding van meerkosten of gederfde inkomsten. En voor het nemen van strategische beslissingen door melkveehouders is het belangrijk dat duidelijk is dat deze beloningen ook over een lange termijn (10 jaar) overeind blijven.

\section{Bedreigingen}

De jonge melkveehouder is hoog opgeleid. In combinatie met het relatief lage inkomen in de melkveehouderij is dit een bedreiging voor de animo om het bedrijf over te nemen. Deze generatie heeft in principe ook andere mogelijkheden buiten het bedrijf om een inkomen te realiseren.

Zowel vanuit het beleid (in het kader van kringlooplandbouw) als vanuit de sector (meer grondgebondenheid) wordt voerproductie op het eigen bedrijf of in de regio als belangrijk gezien. Door de hoge grondprijzen kan dit snel leiden tot hogere kosten in tegenstelling tot de inkoop van voer elders. De hoge grondprijzen worden mede veroorzaakt door een grote vraag naar grond, zowel vanuit 
andere landbouwsectoren (teelten met hoge saldo's zoals boomteelt), maar ook voor infrastructuur en bouwterreinen.

Niet van toepassing: hoge kosten voor arbeid. Hoge kosten voor arbeid zijn niet als bedreiging voor melkvee opgenomen omdat betaalde arbeid een relatief kleine rol speelt in deze sector.

Rond stikstof en klimaat zijn recent doelen vastgesteld die van invloed kunnen zijn op de kosten van melkveebedrijven. Voor beide thema's zijn bijvoorbeeld investeringen in nieuwe stalsystemen in beeld die in lagere emissies resulteren.

Niet van toepassing: Ongelijk speelveld; markt neemt producten af uit buitenland die onder andere veelal lagere - eisen zijn geproduceerd

Het ongelijke speelveld (markt neemt producten af uit buitenland die onder andere - veelal lagere eisen zijn geproduceerd) speelt minder voor de melkveehouderij omdat de melkveehouderij vooral zelf exporteert. De hogere duurzaamheidseisen en de daarmee mogelijk gepaard gaande hogere kosten kunnen wel beperkend worden ten aanzien van de exportpositie. Overigens maken deze hogere kosten op termijn ook verdringing op de thuismarkt mogelijk. 
(b) Vergroten van de marktgerichtheid en van het concurrentievermogen, onder meer door beter te focussen op onderzoek, technologie en digitalisering;

SWOT-samenvatting subdoelstelling B - Vergroten van de marktgerichtheid en van het concurrentievermogen, onder meer door beter te focussen op onderzoek, technologie en digitalisering

\begin{tabular}{|c|c|}
\hline & \\
\hline $\begin{array}{l}\text { - Goede uitgangspositie logistiek, infrastructuur, organisatie } \\
\text { sectoren } \\
\text { - Handelspositie omvangrijk, zowel in goederen als in } \\
\text { kennis } \\
\text { - Beleid Topsectoren } \\
\text { - Innovaties in technieken, producten, processen } \\
\text { - Organisatievermogen, samenwerking en innovatiekracht } \\
\text { sector }\end{array}$ & $\begin{array}{l}\text { - Grootschaligheid en intensiteit productie } \\
\text { - Wet van de remmende voorsprong: toenemende druk } \\
\text { - Hoge wet- en regelgevingsdruk, deels bovenwettelijk, met } \\
\text { nauwelijks verwaarding van de extra kosten } \\
\text { - Hoge grondprijzen, die mede leiden tot kostprijsverhoging } \\
\text { bij extensivering } \\
\text { - Hoge financieringslasten beperken } \\
\text { ontwikkelingsmogelijkheden (met name middengroep) }\end{array}$ \\
\hline & \\
\hline $\begin{array}{l}\text { - Toenemende vraag maatschappij naar duurzame(re) } \\
\text { producten } \\
\text { - Instituties in en om de landbouw meer aandacht voor } \\
\text { andere vormen van landbouw dan de klassieke op } \\
\text { kostprijsverlaging gerichte modellen } \\
\text { - Vraag naar bedrijfssystemen met minder externe effecten } \\
\text { (kringlopen) } \\
\text { - Stimuleren natuurinclusieve landbouw, zoals Green Deal } \\
\text { Natuurincl. landbouw } \\
\text { Digitalisering/Internet of Things: meer } \\
\text { gegevensstromen/transparantie, mogelijkheden precisie- } \\
\text { en kringloop-landbouw, grondgebruik, mogelijkheden tot } \\
\text { vernieuwing productie- en verdienmodel }\end{array}$ & $\begin{array}{l}\text { - Maatschappelijk draagvlak voor de huidige } \\
\text { - Vroductiemethoden neemt af } \\
\text { - landbouwmodel discussie over volhoudbaarheid huidige dominante } \\
\text { - Bereidheid consumenten te betalen voor een duurzame } \\
\text { plus vooralsnog beperkt } \\
\text { - Import van goedkopere grondstoffen } \\
\text { - Onvoldoende positieve prikkels vanuit keten voor } \\
\text { digitalisering } \\
\text { - Verdere druk op concurrentiepositie door de } \\
\text { landbouwontwikkeling in veel landen (zowel binnen de EU } \\
\text { als op wereldniveau) die ook deels wordt veroorzaakt door } \\
\text { emigrerende Nederlandse melkveehouders }\end{array}$ \\
\hline
\end{tabular}

\section{Sterkte punten}

De zuivelsector is goed georganiseerd. Binnen het topsectorenbeleid lopen diverse privaat-publieke samenwerkingen die mede door de zuivelsector zijn geïnitieerd. ZuivelNL speelt hierbij als ketenorganisatie waarbij zowel de zuivelverwerkers (NZO) als diverse organisaties van melkveehouders (LTO, NMV en NAJK) zijn aangesloten een belangrijke rol. Via een heffing is budget beschikbaar dat onder andere in onderzoek en innovatie wordt geïnvesteerd. Daarnaast wordt een aantal zaken rond diergezondheid via ZuivelNL gereguleerd. Daarnaast heeft de sector een eigen innovatie-initiatief Courage.

Niet van toepassing: Sterke Groei R\&D agribusiness, toename innovatief vermogen. Duurzame investeringen op koers

De sterke groei van R\&D agribusiness is hier niet opgenomen omdat deze niet afzonderlijk voor de melkveehouderij in beeld is. De zuivelsector als geheel zet wel zelf onderzoek uit en participeert ook veel in privaat-publieke samenwerkingen binnen het topsectorbeleid.

Ook duurzame investeringen op koers is niet opgenomen omdat hier voor de melkveehouderij geen concrete gegevens of referentie voor beschikbaar is. Er is wel geïnvesteerd in duurzame energieproductie op melkveebedrijven en ook in emissiearme stallen, maar de achterliggende sectorale doelen op het gebied van duurzame energieproductie en ammoniakemissie zijn nog niet bereikt (Bron: sectorrapportage).

\section{Zwakke punten}

Bij de zwakke punten zijn geen aanpassingen doorgevoerd ten opzichte van de oorspronkelijke tabel. 


\section{Kansen}

De toenemende vraag naar duurzame producten is een kans. Belangrijk is dat de te realiseren extra opbrengst en de eventuele meerkosten en de gederfde opbrengsten door noodzakelijke aanpassingen in de bedrijfsvoering overstijgen.

Digitalisering en goede gestroomlijnde datastromen bieden kansen. Voor een deel gebeurt dat al in de melkveehouderij. Kengetallen die uit de kringloopwijzer komen (BEX) spelen bijvoorbeeld al een rol in de hoeveelheid mest die een melkveebedrijf op zijn bedrijf kan gebruiken en waarmee dus mestafzetkosten worden bespaard. Het marktconcept 'On the way to PlanetProof' is ook in belangrijke mate gebaseerd op (een betere score op) kengetallen uit de kringloopwijzer. Onder andere in Drenthe en Noord-Brabant worden experimenten uitgevoerd waar melkveehouder vergoedingen of rente korting krijgen op leningen bij een betere score op kengetallen uit de biodiversiteitsmonitor.

\section{Bedreigingen}

De beperkte mogelijkheden om de verduurzaming van de productie te verwaarden is een belangrijke bedreiging voor de melkveehouderij. Dit is onder andere zichtbaar in de beperkte groei van de afzet van biologische zuivel en duurzaamheidsconcepten als 'On the way to PlanetProof'. De duurzaamheidseisen nemen toe en voor een deel leiden deze eisen ook tot hogere kosten. Als zich hier geen markt voor ontwikkeld dan is dit een bedreiging.

De beperkte marktvraag is ook de belangrijkste reden voor de langzame ontwikkeling van de biologische melkveehouderij. Zeker in Nederlandse omstandigheden met hoge grondprijzen gaat de extensievere biologische productie gepaard met een hogere kostprijs, deze moet dan wel in de markt worden gecompenseerd. 


\section{(c) Verbeteren van de positie van de landbouwers in de waardeketen;}

SWOT-samenvatting subdoelstelling C Verbeteren van de positie van de landbouwers in de waardeketen

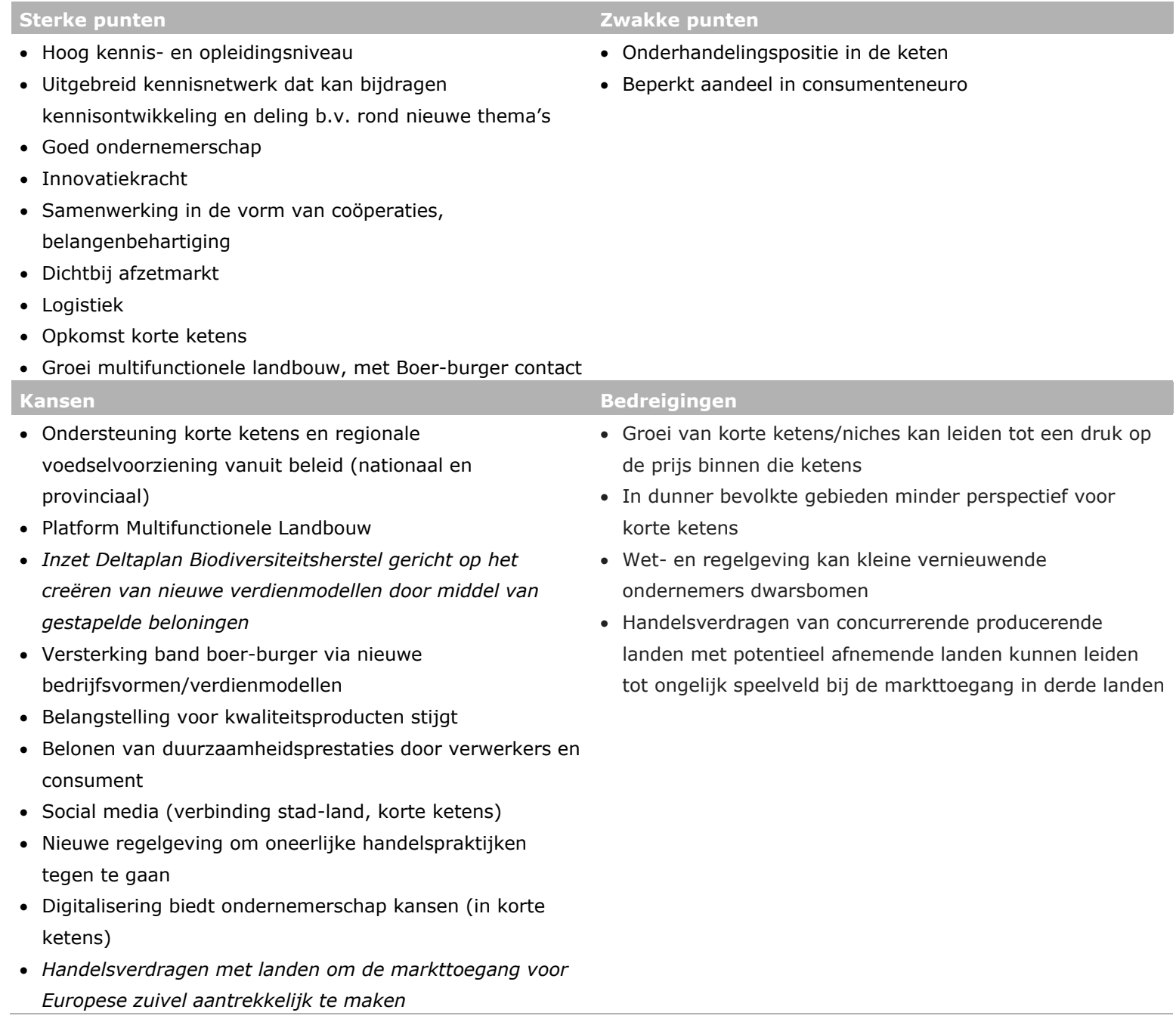

\section{Sterke punten}

Het opleidingsniveau is hoog en er is een traditie van kennisdelen, onder andere via studiegroepen die het snel mogelijk maakt om nieuwe thema's op te pikken.

Een aantal individuele ondernemers is actief in ontwikkeling van eigen bedrijfssystemen met een eigen afzet (onder andere Graasboerderij, Remeker kaas, Elkemelk). De directe afzet neemt toe, maar vormt op het grote geheel nog een klein aandeel. In totaal wordt $96 \%$ van de melk via zuivelverwerkers afgezet. Een in 2020 uitgevoerde enquête laat zien dat een grote groep landbouwbedrijven, waaronder ook melkveebedrijven, steeds meer bronnen van inkomsten hebben.

De samenwerking binnen de sector is ook onder het vorige punt geschetst.

Niet van toepassing: kleine afstand stad - platteland.

De kleine afstand stad/land is niet opgenomen omdat dit slechts voor een klein deel van de melkveehouders een relevant punt is. Het overgrote deel van de geproduceerde melk wordt via een zuivelverwerker afgezet. De afzetmarkt dichtbij is wel als sterk punt opgenomen. Het grootste deel van de afzet van de Nederlandse Zuivelproducten vindt in Noordwest-Europa plaats (Nederland, Duitsland, België en Frankrijk) met beperkte transportafstanden en consumenten die een concreet beeld kunnen hebben van de Nederlandse melkveehouderij met de koe in de wei. 


\section{Zwakke punten}

In principe hebben melkveehouders een zwakke positie in de keten omdat ze hun product niet langdurig op kunnen slaan. Dit is ook één van de redenen van het ontstaan van coöperaties. Een meerderheid van de melkveehouders zet de melk via coöperaties af.

Bij consumptiemelk gaat circa $50 \%$ van de consumentenprijs naar de melkveehouder (op basis van de periode 2017-2018).

Niet van toepassing: Import andere kwaliteit, moeilijk mee te concurreren op prijs

De import van andere kwaliteit zuivel, waar moeilijk mee te concurreren is op prijs is niet opgenomen omdat dit in de melkveehouderij minder speelt. Overigens kan dit in de toekomst wel gaan spelen als de Nederlandse kostprijs door aanvullende duurzaamheideisen verder oploopt. Een belangrijk deel van de dagverse zuivel wordt in Nederland als weidemelk afgezet, daarmee heeft Nederland een voordeel in de markt. In de buurlanden die ook naar Nederland exporteren wordt minder weidegang toegepast, of in ieder geval niet als afzonderlijke deelstroom verwerkt.

\section{Kansen}

Het Deltaplan biodiversiteitsherstel werkt aan de mogelijkheid van het stapelen van beloningen onder andere voor het leveren van ecosysteemdiensten. Op dit moment wordt in een aantal gebieden geëxperimenteerd met vergoedingen voor betere prestaties op indicatoren uit de biodiversiteitsmonitor en zijn er bijvoorbeeld pilots met vergoedingen voor koolstofvastlegging of het vermijden van $\mathrm{CO}_{2}$-uitstoot vanuit veen. Dit biedt op termijn misschien mogelijkheden voor een groter deel van de sector om andere inkomstenbronnen te genereren.

Verwaarding van duurzamer geproduceerde zuivel komt in verschillende concepten aan bod: On the way to PlanetProof (SMK, onder meer toegepast door FrieslandCampina), Beter voor Koe, Natuur en Boer (Albert Heijn en A-ware) en Beter Leven keurmerk (met naast dierenwelzijn ook eisen voor natuur en milieu opgezet door Dierenbescherming, Natuur \& Milieu en Vogelbescherming Nederland) en weidemelk. Deze concepten gelden voor de Nederlandse markt en niet voor de geëxporteerde zuivel. Het VLOG keurmerk (keurmerk voor zuivel zonder genetische gemanipuleerd voer) wordt ook gehanteerd voor export zuivel, met name voor Duitsland.

Handelsverdragen die meer ruimte geven voor export van Europese zuivel zijn voor de Nederlandse zuivel van belang vanwege het hoge aandeel export.

Niet van toepassing: Met producentenorganisaties rol in de keten versterken Producentenorganisaties zijn op dit moment nauwelijks actief in de melkveehouderij. Een belangrijk deel van de melk wordt via coöperaties afgezet. Er is een in 2021 erkende PO Melkveehouderij, maar er is geen nadere informatie bekend over achtergrond, doel en omvang.

\section{Bedreigingen}

Voor de afzet naar derde landen zijn handelsverdragen van belang. De afzet van babymelkpoeder naar China heeft een belangrijke bijdrage geleverd aan de waarde van de Nederlandse melk. Als concurrerende landen op deze markt (met name Nieuw-Zeeland en de Verenigde Staten) beter toegang krijgen tot deze markten (met name Azië) dan is dat een potentiële bedreiging. 


\section{(d) Bijdragen tot matiging van en aanpassing aan klimaatverandering en tot duurzame energie;}

SWOT-samenvatting subdoelstelling D Bijdragen aan mitigatie en adaptatie aan klimaatverandering en leveren van een bijdrage aan een duurzame energieproductie

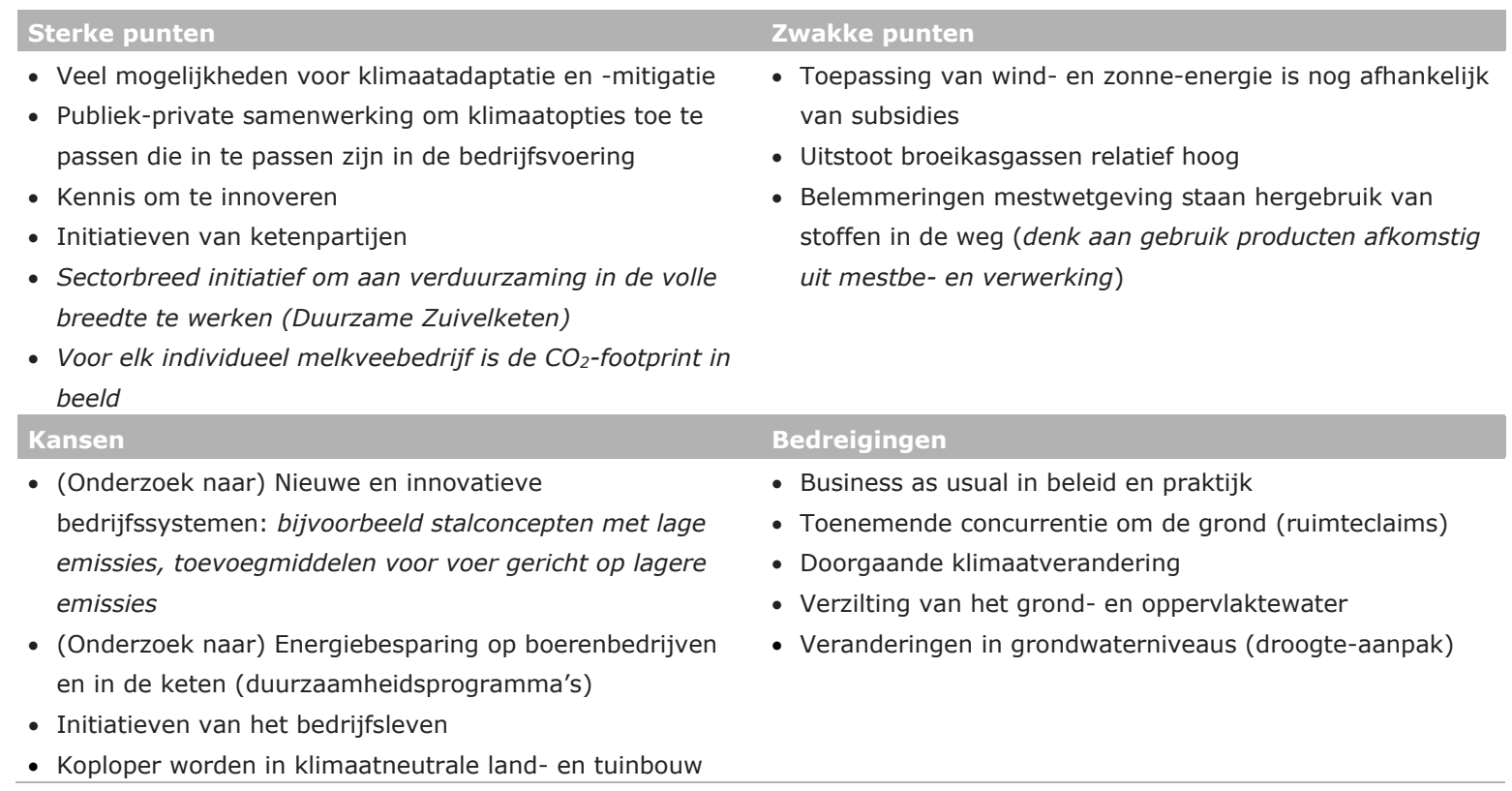

\section{Sterke punten}

De sector (NZO, LTO, NMV en NAJK) werkt gezamenlijk in het initiatief Duurzame Zuivelketen aan een aantal doelen op het gebied van klimaatverantwoorde zuivelproductie, continu verbeteren van diergezondheid en dierenwelzijn, behoud van weidegang en biodiversiteit en milieu. Voor deze thema's waren doelen voor 2020 geformuleerd die jaarlijks onafhankelijk worden gemonitord. Inmiddels zijn nieuwe doelen geformuleerd voor 2030, waarbij ook een aantal thema's is toegevoegd: verdienmodellen, grondgebonden melkveehouderij en veiligheid op het erf. Verbetering van energieefficiency, duurzame energieproductie en reductie van broeikasgasemissies maken deel uit van de doelen van Duurzame Zuivelketen. De doelstelling voor energie-efficiencyverbetering voor 2020 is gehaald. De doelen voor productie van duurzame energie en reductiebroeikasgasemissies niet (tabel C.43b).

Mede op basis van een al bestaande infrastructuur voor data-uitwisseling is voor elk individueel melkveebedrijf een eigen $\mathrm{CO}_{2}$-voetafdruk beschikbaar. Deze speelt al een rol in een aantal ketenconcepten, daarnaast wordt er in diverse verbanden al veel kennis, met name in studiegroepen, op dit thema uitgewisseld.

\section{Zwakke punten}

Belemmeringen in de mestwetgeving door het niet in kunnen zetten van producten uit mestbe- en verwerking als kunstmestvervanger is een rem op innovatie op dit vlak.

Niet van toepassing: Goedkope fossiele brandstoffen vertragen transitie. Teelt biomassa kan niet concurreren met teelt akkerbouwgewassen

De vertragende rol van goedkope fossiele brandstoffen is voor melkvee niet opgenomen omdat brandstoffen slechts een klein deel van de voetafdruk uitmaken. Dus het speelt wel maar is minder van belang. De concurrentie tussen de teelt van biomassa en akkerbouwgewassen is niet opgenomen omdat deze niet past bij de melkveehouderij.

\section{Kansen}

Er wordt veel onderzoek gedaan naar stalconcepten en andere maatregelen met name gericht op het geïntegreerd reduceren van ammoniak en methaanemissie. 
Het sterke punt van de samenwerking binnen Duurzame Zuivelketen en de eerder genoemde beschikbaarheid van data en kengetallen voor de individuele melkveehouder is ook een kans richting te toekomst op voorwaarde dat de samenwerking effectief wordt ingevuld en omgezet in concrete acties.

Duurzame energieproductie is één van de thema's binnen Duurzame Zuivelketen. De productie van duurzame energie is voor de melkveehouderij weliswaar gestegen naar 6,3\%, maar het doel van $16 \%$ in 2020 is nog niet gehaald. Als alle windmolens en co-vergistingsinstallaties die op landbouwgrond van melkveebedrijven plaatsvindt zou worden meegeteld, dan zou het doel wel worden gehaald.

\section{Bedreiging}

De klimaatopgave is groot en de gevolgen kunnen voor de melkveehouderij ook groot zijn. 'Business as usual' in beleid en praktijk zullen niet volstaan om dit probleem op te lossen. Voor de lange termijn doelen van het klimaatakkoord zijn nog forse stappen nodig. 


\section{(e) Bevorderen van duurzame ontwikkeling en efficiënt beheer van natuurlijke}

hulpbronnen zoals water, bodem en lucht;

SWOT-samenvatting subdoelstelling E Bevorderen van duurzame ontwikkeling en efficiënt beheer van natuurlijke hulpbronnen, zoals water, bodem en lucht

\begin{tabular}{|c|c|}
\hline Sterke punten & Zwakke punten \\
\hline $\begin{array}{l}\text { - Efficiënte productie per eenheid product } \\
\text { - Milieudruk grond en oppervlaktewater met } \\
\text { gewasbeschermingsmiddelen, stikstof en fosfaat is stabiel } \\
\text { tot afgenomen } \\
\text { - Initiatieven in sector en keten om milieubelasting } \\
\text { - } \text { productie terug te brengen } \\
\text { - } \text { van natuurlijke hulpbronnen te verminderen } \\
\text { werken aan verduurzaming (Duurzame Zuivelketen) }\end{array}$ & $\begin{array}{l}\text { - Nog niet alle milieudoelstellingen zijn gehaald, vergt ook } \\
\text { nog veel inspanning } \\
\text { - Te veel focus op enkelvoudige doelstellingen } \\
\text { - Te weinig aandacht voor het systeem en de onderlinge } \\
\text { afhankelijkheden } \\
\text { - Verschillende milieuproblemen zijn meer gebaat bij een } \\
\text { - Kegionale aanpak dan bij de huidige generieke aanpak }\end{array}$ \\
\hline Kansen & Bedreigingen \\
\hline
\end{tabular}

\section{Sterke punten}

De samenwerking binnen het initiatief duurzame zuivelketen is al eerder genoemd. Met name op het gebied van het behoud van weidegang en terugdringen van het antibioticagebruik zijn de afgelopen jaren duidelijke resultaten geboekt (tabel C.47). Voor broeikasgasemissies is de laatste jaren (globaal sinds de introductie van fosfaatrechten) een dalende tendens zichtbaar. Recent en lopend onderzoek laat nog perspectief voor verbetering zien bijvoorbeeld voor methaan en broeikasgasemissies (is deels kans).

\section{Zwakke punten}

De melkveehouderij levert een grote bijdrage aan de ammoniakemissie, de laatste jaren is hier relatief ook weinig vooruitgang op geboekt (figuur C46b). Nog niet alle milieudoelstelling zijn gehaald, dit vergt voor een aantal punten ook nog veel inspanning. Dit geldt bij voorbeeld voor klimaat en zeker voor ammoniak.

Niet van toepassing: Grens aan wat technisch haalbaar is, is hier niet opgenomen. Er blijkt in principe technisch nog veel mogelijk. Daadwerkelijke implementatie en borging zijn niet altijd eenvoudig. Met name rond ammoniak en biodiversiteit past een regionale insteek waarschijnlijk beter dan de huidige vooral generieke benadering.

\section{Kansen}

Aan kansen is toegevoegd dat onderzoek en praktijk volop aan nieuwe bedrijfssystemen en innovaties voor verduurzaming werken. Dit gebeurt bij voorbeeld in projecten als 'Koeien \& Kansen' en project rond regeneratieve landbouw.

\section{Bedreigingen}

De invulling van het beleid rond het stikstofdossier en met name de onduidelijkheid en de onzekerheid is belangrijke bedreiging voor de melkveehouderij. De laatste jaren heeft de droogte in de zomerperiode een grote impact op de voerproductie van in ieder geval een deel van de melkveebedrijven. De kans is aanwezig dat dit structureler wordt in verband met het veranderende klimaat.

Niet van toepassing: Verzilting en verslemping is niet als bedreiging opgenomen omdat dit in de melkveehouderij minder speelt dan in de andere grondgebonden sectoren. 
(f) Bijdragen tot de bescherming van de biodiversiteit, versterken van ecosysteemdiensten en in stand houden van habitats en landschappen.

SWOT-samenvatting subdoelstelling F Bijdragen aan de bescherming van de biodiversiteit, het versterken van ecosysteemdiensten en in stand houden van leefgebieden en landschappen

$\begin{array}{ll}\text { Sterke punten } & \text { Zwakke punten } \\ \text { - De diversiteit van het Nederlandse landschap door de } & \text { - De zeer zorgelijke toestand van biodiversiteit, } \\ \text { ligging in een vruchtbare delta, de variatie in } & \text { ecosysteemdiensten en landschappen in het landelijk } \\ \text { grondsoorten en de ontginningsgeschiedenis } & \text { gebied en het vooralsnog ontbreken van een positieve } \\ \text { - Stelsel voor collectief agrarisch natuur- en } & \text { trend } \\ \text { landschapsbeheer, waarmee gebiedsgericht aan de slag } & \text { - Het beperkte areaal dat onder collectief beheer kan } \\ \text { wordt gegaan voor biodiversiteit } & \text { worden gebracht } \\ \text { - Groeiende bereidheid bij boeren om zich in te zetten voor } & \text { - Biodiversiteit maakt beperkt deel uit van de agrarische } \\ \text { natuur, ecosysteemdiensten en biodiversiteit } & \text { bedrijfsvoering. De vergoeding blijft beperkt tot de } \\ \text { - Ontwikkelingen in de keten om biodiversiteit in de } & \text { meerkosten en opbrengstenderving en levert daarmee } \\ \text { landbouw te belonen } & \text { geen bijdrage aan een betere financiële positie } \\ \text { - Elk melkveebedrijf heeft inzicht in score op een aantal } & \text { - Het betalen voor biodiversiteit door de markt en de } \\ \text { indicatoren die gerelateerd zijn aan biodiversiteit } & \text { consument is nog geen gemeengoed } \\ \text { - Groot deel van de melkveehouders is lid van een } & \text { - Landbouwgrond in Nederland is duur, extensivering voor } \\ \text { agrarische natuurvereniging } & \text { biodiversiteit is op bedrijfsniveau alleen aantrekkelijk als } \\ \text { - Groot deel van de melkveehouders past een vorm van } & \text { er voldoende beloning tegenover staat } \\ \text { natuurbeheer toe } & \end{array}$
natuurbeheer toe

- Groeiende maatschappelijke en politieke aandacht voor

- Groeiende maatschappelijke en politieke aandacht voor
belang biodiversiteit (zoals onder andere tot uiting komt in het Deltaplan Biodiversiteitsherstel)

- Verbeteren van bodemkwaliteit en biodiversiteit levert mogelijk ook voordelen voor melkveehouders op b.v. minder impact van droogte

- Toenemende belangstelling bij boeren voor natuurinclusieve landbouw

- Streven van de overheid om zones van extensieve landbouw rondom Natura 2000-gebieden te ontwikkelen

- Ontwikkeling van vergoedingen voor ecosysteemdiensten, in verschillende vormen van publiek-private samenwerking

- Biologische melkveehouderij is in staat om zonder extra maatregelen of grote aanpassingen bijdrage aan biodiversiteit of andere ecosysteemdiensten te leveren Bedreigingen

- Intensivering agrarisch landgebruik (resulterend in vermesting, verdroging, verzuring, versnippering)

- Industrialisering, verstedelijking en toename infrastructuur

- Klimaatverandering

- Energietransitie met aanleg van zonne-akkers en zonneweiden, evenals biomassagewassen

- Geen consistente registratie van landschapselementen. Alleen de landschapselementen waar subsidie voor ontvangen wordt zijn geregistreerd in het perceelsregister RVO

- Afname van insecten leidt tot minder natuurlijke bestuivers voor de landbouw

- Ontbreken van integraal beleid en concreet lange termijn doelen voor bij voorbeeld bodem, mest, klimaat, biodiversiteit en landschap

- Innovatievermogen door combinatie van kennis en expertise in de agrifoodsector, met kennis van ecologie en biodiversiteit

\section{Sterke punten}

Alle melkveebedrijven nemen deel aan de kringloopwijzer. Dit instrument geeft onder andere inzicht in de stikstof en fosfaatstromen op een melkveebedrijf. De kengetallen uit de kringloopwijzer vormen een belangrijke basis onder de biodiversiteitsmonitor. Deze monitor geeft inzicht in de impact van het melkveebedrijf op biodiversiteit (op basis van indicatoren als aandeel blijvend grasland, percentage eiwit van eigen bedrijf, stikstofbodemoverschot, ammoniakemissie, broeikasgasemissies) en de directe bijdrage aan biodiversiteit (aandeel kruidenrijk grasland en aandeel land met beheerscontracten).

Een groot deel (42\%) van de melkveehouders is lid van een agrarische natuurvereniging. Een meerderheid van de melkveehouders (63\%) past een vorm van natuurbeheer toe.

\section{Zwakke punten}

Biodiversiteit maakt beperkt deel uit van de bedrijfsvoering van gangbare melkveebedrijven. Een meerderheid van de melkveehouders past weliswaar een vorm van natuurbeheer toe, maar het blijft per bedrijf qua omvang meestal beperkt bijvoorbeeld tot percelen op afstand of randen. Voor een duidelijke toename is de huidige beloning onvoldoende. De vergoeding blijft over het algemeen 
beperkt tot de meerkosten en opbrengstenderving en levert daarmee feitelijk geen bijdrage aan een verbetering van de financiële situatie.

\section{Kansen}

De belangstelling voor biodiversiteit en natuurinclusieve landbouw neemt in de praktijk toe. Dit is bijvoorbeeld zichtbaar in thema's die in studiegroepen worden opgepakt zoals verbetering van bodemkwaliteit en kruidenrijk grasland. Als uit een bredere toepassing in de praktijk blijkt dat bij voorbeeld kruidenrijk grasland goed inpasbaar is en een betere bodemkwaliteit bij voorbeeld ook leidt tot minder impact van droogte en daarmee ook direct voordeel voor de melkveehouder zelf oplevert, dan is dit gunstig zowel voor de melkveehouder zelf als voor de verbetering van biodiversiteit. De bestaande structuren voor kennisuitwisselingen en de brede beschikbaarheid van data kunnen vervolgens voor een snelle kennisdeling en toepassing zorgen.

Biologische melkveebedrijven zijn in staat om zonder extra maatregelen of grote aanpassingen een bijdrage aan biodiversiteit of andere ecosysteemdiensten te leveren.

\section{Bedreigingen}

Voor verbetering van biodiversiteit, het leveren van ecosysteemdiensten en het sluiten van kringlopen lijkt een extensivering van de melkveehouderij gewenst. De grote druk op landgebruik (onder andere vanuit infrastructuur, woningbouw en toenemend vanuit zonneparken) maakt dit lastig.

Daarnaast komen veel verschillende beleidsthema's op het melkveebedrijf bij elkaar. Er is voor de lange termijn geen concreet beeld van de eisen waar het melkveebedrijf aan moet voldoen. Dit maakt het voor melkveehouders lastig om strategische keuzen te maken. Een recent onderzoek naar de melkveehouderij in 2030 laat zien dat het gelijktijdig verbeteren van de duurzaamheid en het economisch perspectief geen eenvoudige opgave is (Beldman et al., 2020). Als belangrijkste opgave wordt in dat onderzoek benoemt om met alle relevante stakeholders gezamenlijk bij elkaar passende maatregelen, sturing en economische perspectief te ontwikkelen gericht op de lange termijn. 


\subsection{Referenties}

Beldman, Alfons, Joan Reijs, Co Daatselaar en Gerben Doornewaard (2020). De Nederlandse melkveehouderij in 2030; Verkenning van mogelijke ontwikkelingen op basis van economische modellering. Wageningen, Wageningen Economic Research, Rapport 2020-09

Doornewaard G.J., M.W. Hoogeveen, J.H. Jager, J.W. Reijs en A.C.G. Beldman (2020).

Sectorrapportage Duurzame Zuivelketen; Prestaties 2019 in perspectief. Wageningen, Wageningen Economic Research, Rapport 2020-120. 210 blz.; 24 fig.; 24 tab.; 96 ref.

Peet, van der G. F. V., R.W. van der Meer, H. Docters van Leeuwen, S.R.M. van Wageningen-Lucardie (2019). Monitoring integraal duurzame stallen: peildatum 1 januari 2019. Wageningen: Wageningen Livestock Research rapport; no. 1183

Zuivel in cijfers: https://www.zuivelnl.org/uploads/images/Publicaties/20200209-ZuivelNL-Zuivel-inCijfers_lowres_spreads.pdf 


\subsection{Bijlage Indicatoren}

N.B. Alle data zijn op basis van Eurostat of nationale data als in Eurostat geen gegevens beschikbaar waren op deelsectorniveau.

Indicatoren C.12 tot en met C.34

Tabel C.12 Aantal bedrijven naar bedrijfsgrootte in ha en standaardopbrengst (SO)

\begin{tabular}{lrrr} 
& \multicolumn{3}{c}{ Melkveebedrijven } \\
\cline { 2 - 4 } Aantal bedrijven naar omvang in ha & 2010 & 2015 & 2020 \\
\hline$<1 \mathrm{ha}$ & & & \\
\hline $1-5 \mathrm{ha}$ & 92 & 121 & 23 \\
\hline $5-10 \mathrm{ha}$ & 215 & 196 & 30 \\
\hline $10-30 \mathrm{ha}$ & 4.062 & 3.297 & 2.155 \\
\hline $30-50 \mathrm{ha}$ & 7.089 & 6.240 & 4.995 \\
\hline$>50$ ha & 6.053 & 6.806 & 7.253 \\
\hline Totaal & 17.519 & 16.699 & 14.572 \\
\hline Gemiddelde oppervlakte (ha cultuurgrond) & 46,65 & 50,78 & 57,51 \\
\hline
\end{tabular}

Aantal bedrijven naar omvang in standaardopbrengst (SO)

\begin{tabular}{|c|c|c|c|}
\hline SO: $3.000-25.000$ euro & 97 & 138 & 35 \\
\hline SO: $25.000-100.000$ euro & 1.252 & 631 & 306 \\
\hline SO: $100.000-250.000$ euro & 8.440 & 4.739 & 2.653 \\
\hline SO: $250.000-500.000$ euro & 6.818 & 8.566 & 7.376 \\
\hline SO: $500.000-1.000 .000$ euro & 856 & 2.374 & 3.621 \\
\hline SO: $1.000 .000-1.500 .000$ euro & 44 & 196 & 458 \\
\hline SO: $1.500 .000-3.000 .000$ euro & 11 & 52 & 112 \\
\hline SO: $>3.000 .000$ euro & 1 & 3 & 11 \\
\hline Totaal & 17.422 & 16.561 & 14.537 \\
\hline \multicolumn{4}{|c|}{ Gemiddelde bedrijfsgrootte in ha en SO } \\
\hline ha & 46,7 & 50,8 & 57,5 \\
\hline SO (x 1.000 euro) & 258 & 349 & 441 \\
\hline \multicolumn{4}{|l|}{ idem $2010=100$} \\
\hline ha & 100 & 109 & 123 \\
\hline SO (x 1.000 euro) & 100 & 135 & 171 \\
\hline
\end{tabular}

Tabel C.13a Arbeidsinzet - in arbeidsjaareenheden

\begin{tabular}{lrrr} 
Melkveebedrijven & 2010 & 2015 & 2020 \\
Arbeidsjaareenheden (regelmatig en onregelmatig) regulier werkzaam & 33.733 & 34.313 & 32.146 \\
\hline Man & 25.859 & n.b. & n.b. \\
\hline Vrouw & 8.874 & n.b. & n.b. \\
\hline Niet-reguliere arbeidsinzet & 1.182 & 1.481 & 1.462 \\
\hline
\end{tabular}

Tabel C.13b Arbeidsinzet: aantal arbeidsjaareenheden naar gezinsarbeid en vreemde arbeid

\begin{tabular}{lrrr} 
Melkveebedrijven & 2010 & 2015 & 2020 \\
\hline Gezin & 32.051 & 32.244 & 29.603 \\
\hline Niet-gezin & 2.863 & 3.550 & 4.004 \\
\hline
\end{tabular}

Tabel C.14 Leeftijdsopbouw agrarische bedrijfshoofden

\begin{tabular}{lrrr} 
Melkveebedrijven & 2010 & 2015 & 2020 \\
$<40$ jaar (A) & 2.059 & 1.429 & 1.182 \\
\hline$>55$ jaar (B) & 5.360 & 5.797 & 6.607 \\
\hline Totaal & 17.519 & 16.699 & 14.572 \\
\hline ratio (A/B) & 38 & 25 & 18 \\
\hline
\end{tabular}

Tabel C.16 Bedrijfsopvolging 


\begin{tabular}{|c|c|c|c|}
\hline Melkveebedrijven & 2012 & 2016 & 2020 \\
\hline aantal bedrijven met een opvolger & 4.887 & 5.197 & 5.572 \\
\hline aantal bedrijven met een bedrijfshoofd $>51$ jaar & 8.572 & 9.410 & 9.563 \\
\hline aandeel bedrijven met een opvolger & 57 & 55 & 58 \\
\hline
\end{tabular}

Tabel C.17 Areaal gewassen melkveebedrijven

\begin{tabular}{lrrr} 
& 2010 & 2015 & 2020 \\
Totaal grasland en voedergewassen & 796.406 & 827.685 & 815.766 \\
\hline Grasland & 668.962 & 720.129 & 707.784 \\
\hline Voedergewassen & 127.444 & 107.556 & 107.982 \\
\hline Akkerbouw & 20.274 & 18.396 & 20.607 \\
\hline Permanent overig & 194 & 211 & 286 \\
\hline Overig & 127.821 & 108.178 & 108.489 \\
\hline TOTAAL & 817.252 & 846.915 & 837.166
\end{tabular}

C18-C21: niet beschikbaar voor melkvee

Tabel C.22/23 Aantal grootvee eenheden, areaal landbouwgrond en veedichtheid per ha 2010 - 2020

\begin{tabular}{lrrr} 
& \multicolumn{3}{c}{ Melkveebedrijven } \\
\cline { 2 - 4 } Aantal grootvee-eenheden & 2010 & 2015 & 2020 \\
\hline Areaal landbouwgrond & 2.063 .556 & 2.260 .329 & 2.011 .279 \\
\hline Veedichtheid per ha in GVE & 817.252 & 846.915 & 835.368 \\
\hline
\end{tabular}

Tabel C.24 Netto toegevoegde waarde per aje (in euro)

\begin{tabular}{lrrr} 
& 2010 & 2015 & 2019 \\
Melkveebedrijven (in euro) & 55.642 & 47.580 & 69.098 \\
\hline Index $(\mathbf{2 0 1 0}=\mathbf{1 0 0})$ & 100 & 86 & 124 \\
\hline
\end{tabular}

Tabel C.25 Inkomen uit bedrijf per oaje (in euro)

\begin{tabular}{lrrr} 
& 2010 & 2015 & 2019 \\
Melkveebedrijven (in euro) & 31.440 & 23.840 & 50.031 \\
\hline Index $(\mathbf{2 0 1 0}=\mathbf{1 0 0})$ & 100 & 76 & 159 \\
\hline
\end{tabular}

Tabel C.26 Netto toegevoegde waarde per arbeidsjaareenheid (in euro) naar bedrijfstype

$\begin{array}{lrrrr} & & 2005 & 2010 & 2015 \\ \text { Melkveebedrijven (in euro) } & \mathbf{5 3 . 6 9 8} & 63.916 & 46.521 & \mathrm{n} . \mathrm{b} .\end{array}$

C. 27 niet beschikbaar.

C.28 niet beschikbaar.

C. 29 niet beschikbaar.

C.30 Handel. 


\section{Zuivel: structuur van de keten 2018}

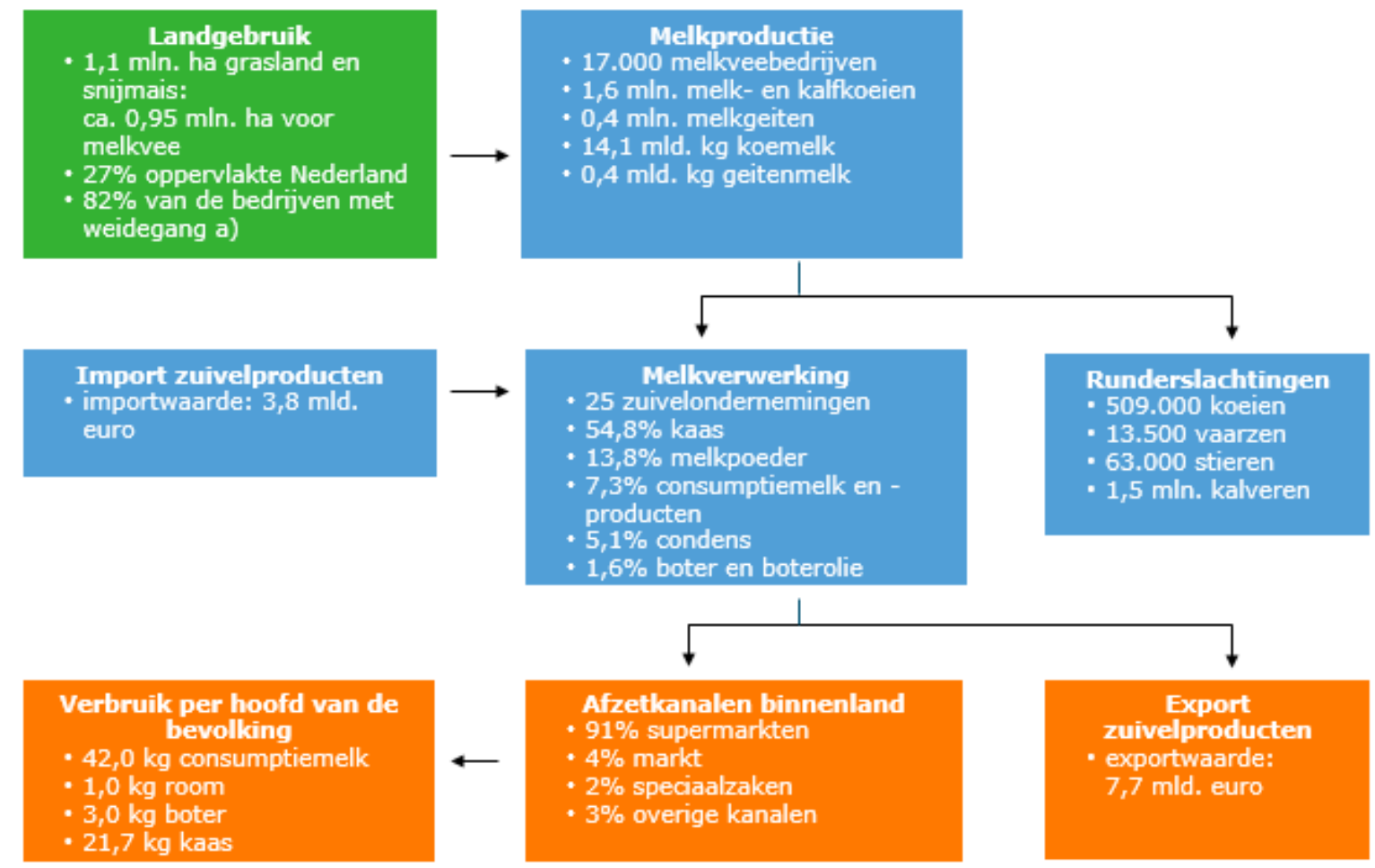

a) Het is het percentage bedrijven waar de melkgevende koeien minimaal 120 dagen, en op elk van die dagen minimaal 6 uur, weiden. Droge koeien, koeien in de eerste 14 dagen van de lactatie en zieke koeien hoeven niet te weiden (website Stichting Weidegang, de controlerende organisatie)

Bron: ZuivelNL, Zuivel in cijfers 2018; bewerking Wageningen Economic Research.

\section{C.31 niet beschikbaar.}

Tabel C.32 Areaal biologische landbouw en aandeel areaal biologische landbouw op totale areaal melkveehouderijsector

\begin{tabular}{lrrrrrr} 
Aantal hectares & 2015 & 2016 & 2017 & 2018 & 2019 & 2020 \\
\hline Totaal areaal biologisch plus in omschakeling & 22.742 & 28.603 & 30.781 & 32.434 & 34.161 & 35.864 \\
\hline Areaal biologisch & 21.024 & 22.169 & 25.013 & 29.650 & 30.847 & 32.352 \\
\hline Areaal in omschakeling & 1.718 & 6.434 & 5.768 & 2.784 & 3.314 & 3.512 \\
\hline Totaal areaal & 888.340 & 875.458 & 853.988 & 844.115 & 872.744 & 20.613 \\
\hline Aandeel (\%) & & & & & & \\
\hline Totaal areaal biologisch plus in omschakeling & 2,6 & 3,1 & 3,5 & 3,8 & 4,0 & 4,1 \\
\hline Areaal biologisch & 2,4 & 2,4 & 2,9 & 3,5 & 3,7 & 3,7 \\
\hline Areaal in omschakeling & 0,2 & 0,7 & 0,7 & 0,3 & 0,4 & 0,4 \\
\hline Totaal areaal & 100 & 100 & 100 & 100 & 100 & 100 \\
\hline
\end{tabular}

Tabel C.33 Intensieve landbouw, aandeel areaal met een hoge inputintensiteit (grond met een totale input van veevoer, kunstmest en gewasbeschermingsmiddelen van meer dan $€ 350$ per ha)

\begin{tabular}{lrrr} 
& 2010 & 2015 & 2019 \\
Melkveebedrijven & 99 & 100 & 99 \\
\hline
\end{tabular}

C.34 niet beschikbaar. 


\section{Indicatoren C.35-C.48}

C.35 niet beschikbaar naar type bedrijf

C.36 niet beschikbaar naar type bedrijf

C.38 niet beschikbaar naar type bedrijf

C.40 niet beschikbaar naar type bedrijf

C.41 niet beschikbaar naar type bedrijf

C.42 niet beschikbaar naar type bedrijf

Tabel C.43 Uitstoot van broeikasgassen door melkveebedrijven (in 1.000 ton $\mathrm{CO}_{2}$-equivalenten)

\begin{tabular}{lrrr} 
& 2010 & 2015 & 2019 \\
Uitstoot & 15.965 & 21.395 & 20.127 \\
\hline Index $(2010=100)$ & 100 & 134 & 126
\end{tabular}

Tabel 2.3 Sector carbon footprint in Mton $\mathrm{CO}_{2}$-equivalenten naar bron, 1990, 2011 en 2014-2019

\begin{tabular}{lrrrrrrrr} 
& $\mathbf{1 9 9 0}$ & $\mathbf{2 0 1 1}$ & $\mathbf{2 0 1 4}$ & $\mathbf{2 0 1 5}$ & $\mathbf{2 0 1 6}$ & $\mathbf{2 0 1 7}$ & $\mathbf{2 0 1 8}$ & $\mathbf{2 0 1 9}$ \\
$\begin{array}{l}\text { Bij de productie van } \\
\text { grondstoffen a) }\end{array}$ & 6,93 & 6,34 & 6,96 & 7,59 & 8,06 & 8,09 & 7,41 & 6,83 \\
\hline $\begin{array}{l}\text { Op melkveebedrijven a) } \\
\text { Totaal melkveehouderij }\end{array}$ & $\mathbf{2 2 , 4 0}$ & $\mathbf{1 9 , 6 4}$ & $\mathbf{2 1 , 0 3}$ & $\mathbf{2 2 , 1 0}$ & $\mathbf{2 3 , 3 7}$ & $\mathbf{2 2 , 5 9}$ & $\mathbf{2 1 , 2 3}$ & $\mathbf{2 0 , 3 1}$ \\
\hline $\begin{array}{l}\text { Transport rauwe melk } \\
\text { (RMO + Intra) b) }\end{array}$ & 0,06 & 0,07 & 0,08 & 0,08 & 0,08 & 0,09 & 0,08 & 0,08 \\
\hline $\begin{array}{l}\text { Energiegebruik } \\
\text { productielocaties c) }\end{array}$ & 1,37 & 1,23 & 1,09 & 1,10 & 1,14 & 1,14 & 1,09 & 1,00 \\
\hline $\begin{array}{l}\text { Verpakkingen b) } \\
\text { Totaal d) }\end{array}$ & 0,27 & 0,26 & 0,29 & 0,30 & 0,31 & 0,30 & 0,29 & 0,31 \\
\hline
\end{tabular}

Bronnen: a) LCA melkveehouderij op basis van het Bedrijveninformatienet van Wageningen Economic Research (tabel 2.4); b) Inschatting op basis van gegevens van zes zuivelondernemingen;

c) Berekend op basis van energiegebruiksgegevens MJA3-Sectorrapport 2019 Zuivelindustrie (RVO, 2020, zie bijlage 1); d) De totale hoeveelheid geleverde melk is gebaseerd op ZuivelNL (2020).

Bron: Sectorrapportage 2019.

C.44 niet beschikbaar naar type bedrijf

C.45 niet beschikbaar naar type bedrijf

Tabel C.46 Ammoniakuitstoot melkveebedrijven (in 1.000 ton NH3) 1990-2018

\begin{tabular}{rrrrrrr} 
& 1990 & 2000 & 2005 & 2010 & 2015 & 2018 \\
Melkveebedrijven & $\mathbf{1 4 9}$ & $\mathbf{5 4}$ & $\mathbf{5 0}$ & $\mathbf{4 8}$ & $\mathbf{5 2}$ & $\mathbf{5 6}$ \\
\hline
\end{tabular}




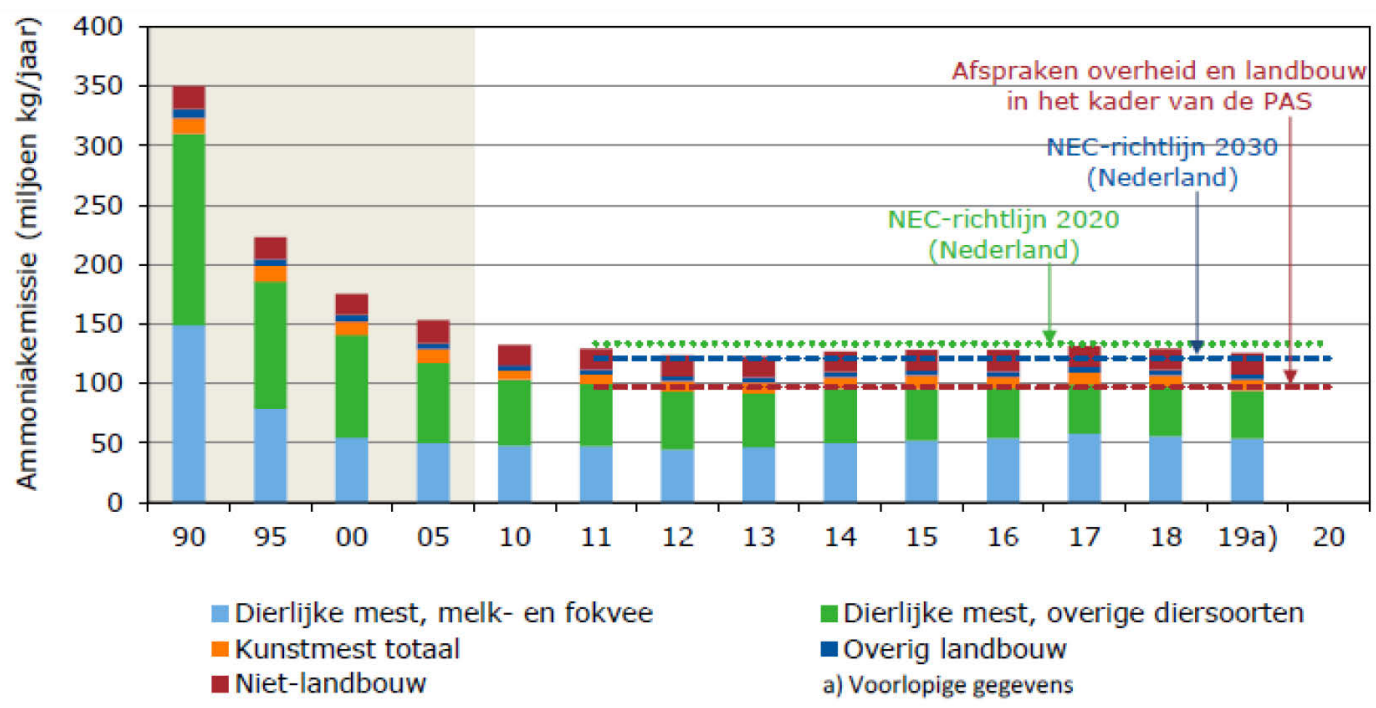

Figuur 5.3 Ammoniakemissie in Nederland in relatie tot NEC-richtlijn doelstelling voor Nederland voor 2020 en 2030 en de doelstelling voor 2030 voor de landbouw zoals afgesproken tussen overheid en land- en tuinbouw in het kader van de PAS (10 kiloton reductie, RVO, 2014b) (cijfers 2019 zijn voorlopig)

Bron: NEMA en Emissieregistratie, bewerkt door Wageningen Economic Research.

Bron: Sectorrapportage 2019.

\section{C.47 Antibiotica: uit sectorrapportage}

Antibioticagebruik DDDA

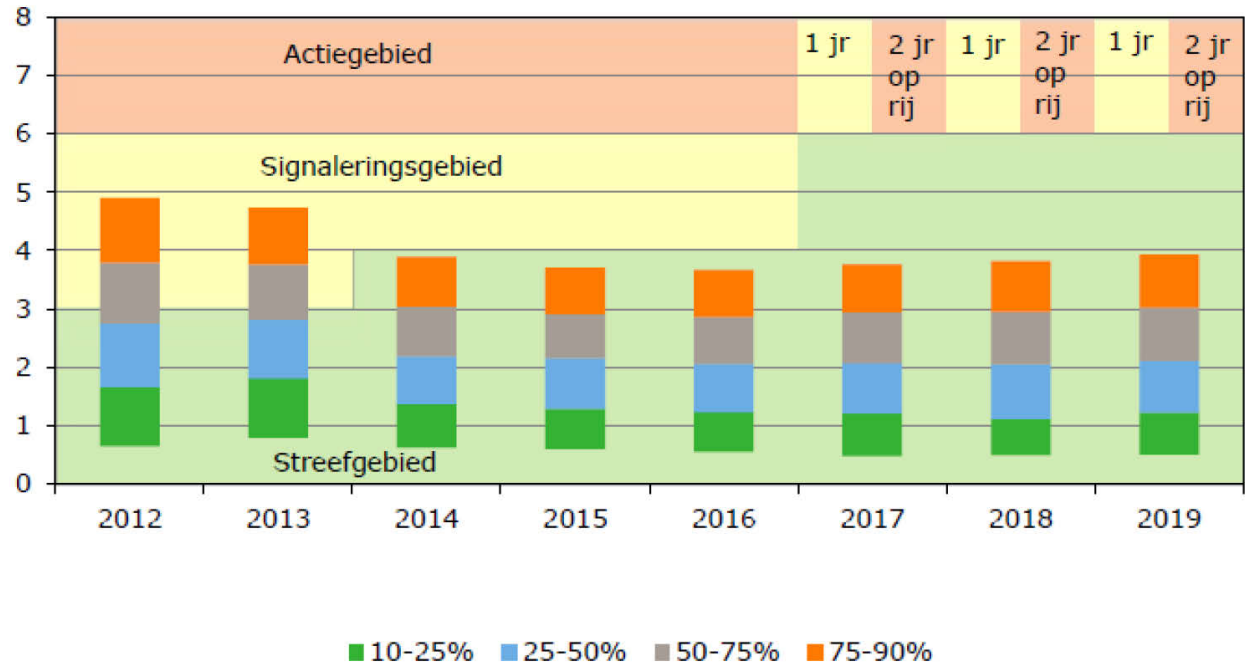

Figuur 3.2 Spreiding in antibioticagebruik op melkveebedrijven in $D D D A_{F}$ in 2012-2019 in relatie tot de SDa-streefgebieden Bron: Autoriteit Diergeneesmiddelen (2020a) (bewerkt door Wageningen Economic Research).

Bron: Sectorrapportage 2019

Tabel C.48 Afzet van pesticiden (1.000 ton werkzame stof)

\begin{tabular}{lrrr} 
& 2010 & 2015 & 2019 \\
Melkveebedrijven & 0,51 & 0,49 & 0,46 \\
\hline
\end{tabular}




\section{SWOT-analyse deelsector glasgroente}

Marc Ruijs

N.B. deze analyse moet worden gelezen in samenhang met de SWOT-analyse op het niveau van de landbouwsector als geheel. Onderhavige analyse verbijzondert de SWOT-analyse waar nodig naar de deelsector in kwestie.

\subsection{Algemene beschrijving van de sector glasgroente}

Korte beschrijving van de sector ${ }^{17}$

De glasgroentesector in Nederland bestaat voornamelijk uit de teelt van tomaat, paprika, komkommer en aubergine. Daarnaast valt er ook de aardbei (onder glas en plastic tunnel) en opkweekmateriaal van groenten onder glas onder. De glasgroentesector is van oudsher sterk vertegenwoordigd in het westen van Nederland (Westland en Oostland) en de regio rond Venlo (Noord-Brabant en Limburg). Door de schaalvergroting na 2000 komt glasgroente ook meer voor in het westen van Noord-Brabant, Zeeland, Noord-Holland en Flevoland. De grootste bedrijven komen nu voor in de locatie AgriportA7 in Noord-Holland Noord. Het areaal glasgroente is na een daling vanaf 2011 sinds 2016 weer gestegen.

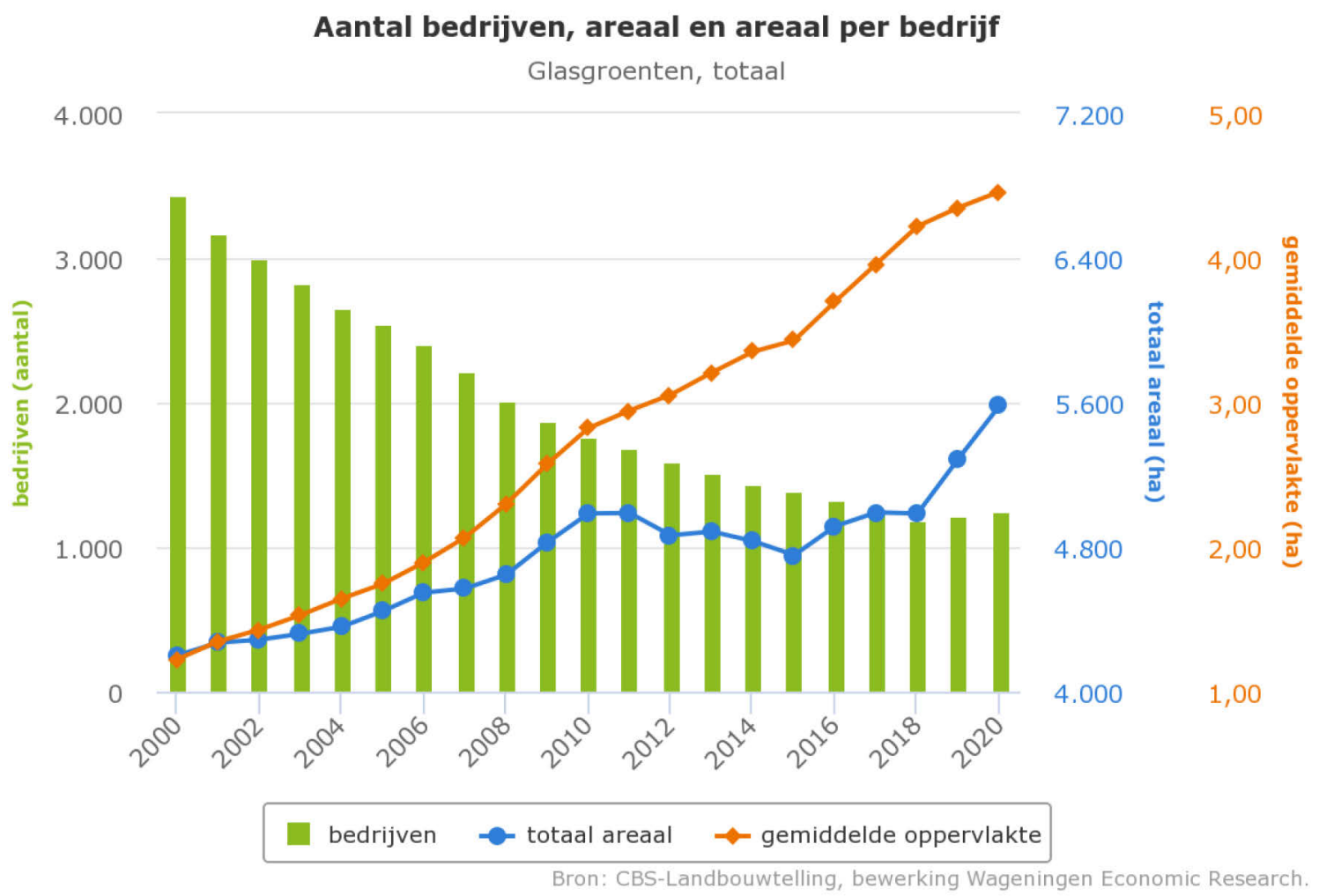

Bovenstaande figuur geeft een beeld van de ontwikkeling van het areaal glasgroente, het aantal glasgroentebedrijven en het areaal per bedrijf. De cijfers in de figuur kunnen afwijken van de cijfers in de bijlage omdat in de bijlage alleen de gespecialiseerde glasgroentebedrijven zijn meegenomen. Op het merendeel van de bedrijven werkt veel vreemd personeel (tabel 13a en tabel 13b).

\footnotetext{
${ }^{17}$ Deze tekst is volledig afkomstig uit Bremmer et al. (2019).
} 
De veiling als fysieke marktplaats voor aanbod en vraag van groenten is vrijwel verdwenen. Producten worden nu hoofdzakelijk via telersverenigingen en producentenorganisaties aan de groothandel en retail verkocht. Meer dan driekwart van de glasgroenteproducten wordt geëxporteerd naar Europa en in het bijzonder naar Duitsland, het Verenigd Koninkrijk en Frankrijk. De concurrentie van andere landen binnen de EU neemt toe.

De afzet van glasgroenten door afzetorganisaties aan groothandel en supermarkten vindt grotendeels via bemiddeling plaats. Een deel van de afzet is via seizoencontracten, waarin vooral afspraken worden gemaakt over de duur van samenwerking, de productspecificaties en de leveringsplicht en niet op voorhand de prijs en volumes. Andere contractvormen komen voor, waarbij vaste prijzen en/of vaste volumes voor het hele seizoen worden afgesproken (Bremmer et al., 2019).

\section{Productiesysteem}

De glasgroentebedrijven betrekken hun uitgangsmateriaal van veredelings- of opkweekbedrijven (Bremmer et al., 2019). Een klein deel betreft zaad (onder andere radijs), maar overwegend worden planten in perspotten of in substraatblokken gebruikt. De glasgroenteteelt vindt voor $10-15 \%$ van het areaal in de grond plaats (sla en andere bladgewassen) en voor het overgrote deel in substraat.

Nieuwe kassen voldoen meestal aan de eisen voor Groen Label Kas, waarmee duurzaamheidsmaatregelen worden gestimuleerd op het terrein van energie, nutriënten en gewasbeschermingsmiddelen. Vanaf 2019 is het aandeel Groen Label Kassen bij nieuwbouw gedaald door aangescherpte energie-eisen.

De gewasbescherming wordt voor een belangrijk deel door de inzet van biologische bestrijders gedaan, waarbij chemisch wordt gecorrigeerd. Een beperkt aantal glasgroentebedrijven teelt volledig biologisch. Per 1 januari 2018 geldt een verplichte zuivering van restwaterstromen.

Zuiveringsinstallaties moeten dan de gewasbeschermingsmiddelen met minimaal $95 \%$ verwijderen uit het te lozen water. Voor een collectief van bedrijven is er respijt tot 2021. In het algemeen zijn er geen grote knelpunten.

De bedrijven telen overwegend één keer of enkele keren per jaar een gewas. Tijdens de teeltwisseling wordt de kas en het productiesysteem 'schoon' gemaakt voor een nieuwe teeltronde. De producten worden hoofdzakelijk via telersverenigingen of producentenorganisaties afgezet en vinden voor $80 \%$ hun bestemming in het buitenland, hoofdzakelijk in Europa.

\section{Aandeel biologisch}

Het aandeel biologische bedrijven met glasgroente is beperkt (alleen mogelijk bij teelten in de grond) en bedraagt in 2020 2,2\% van het totaal areaal glasgroente (cultuurgrond). Dit komt overeen met 141 ha op bedrijven die zijn overgeschakeld of in overschakeling zijn. De overstap naar de biologische glasgroenteteelt is blijkbaar niet eenvoudig en/of de relatief lange overgangstermijn om het label biologisch product te mogen voeren is een obstakel. Binnen de glasgroenten heeft de tomaat het grootste aandeel in het areaal biologisch. Veel van deze producten worden afgezet via de reguliere afzetkanalen (Bremmer et al., 2019).

\section{Handel}

De geschatte uitvoerwaarde van glasgroenten bedroeg in 2019 3,47 miljard euro, de invoerwaarde $€ 0,66$ miljard (tabel C.30).

Onderstaande figuur geeft de export van glasgroenten uit Nederland in kilo's. 


\section{Export vanuit Nederland in kilo's (bron: KCB/ GroentenFruit Huis)}

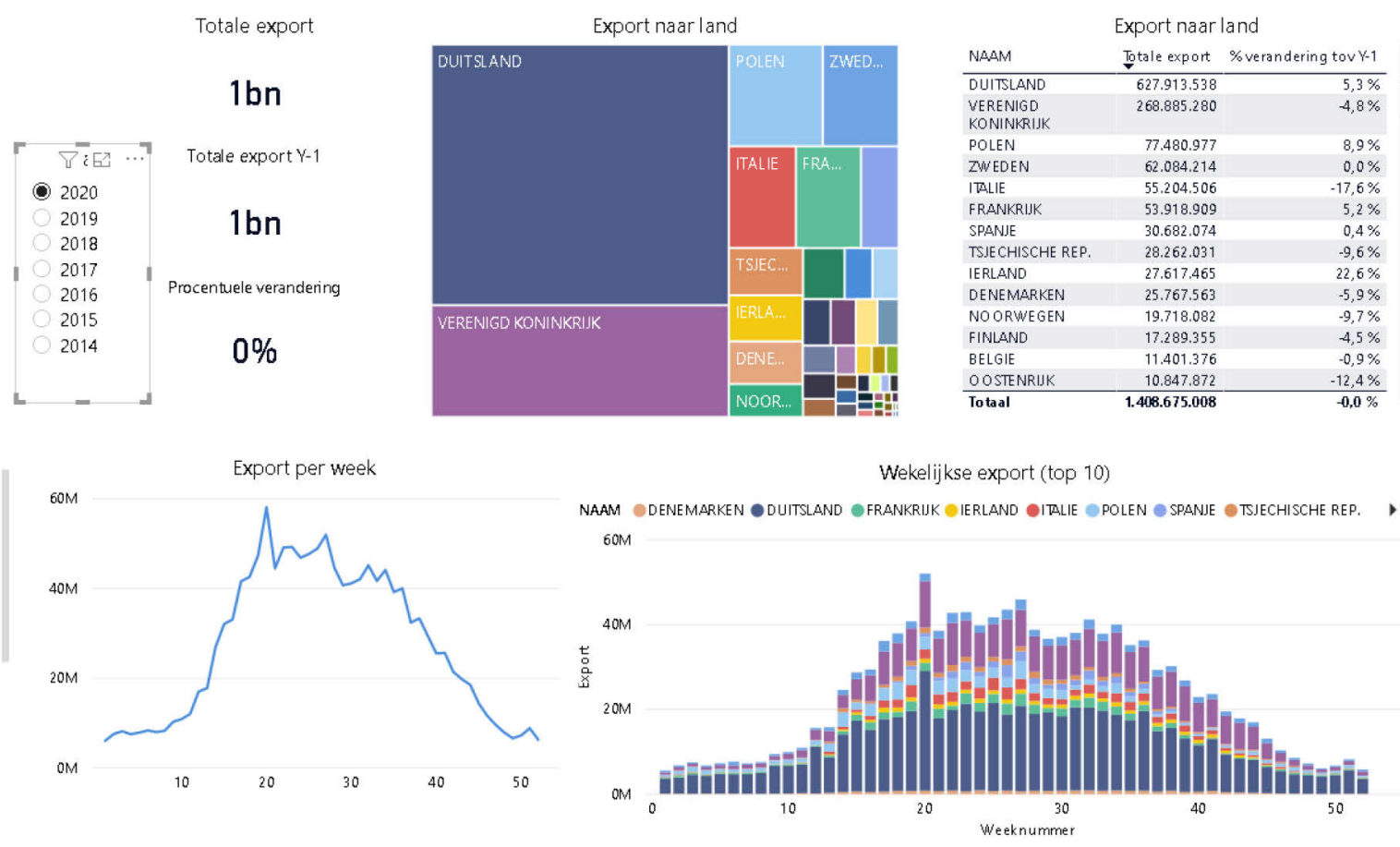

Bron: KCB/GroentenFruitHuis. 


\subsection{SWOT-analyse per specifieke doelstelling}

\section{(a) Bieden van steun met het oog op een leefbaar landbouwinkomen en veerkracht in de hele Unie om de voedselzekerheid te vergroten;}

SWOT-samenvatting subdoelstelling A Bieden van steun met het oog op een leefbaar landbouwinkomen en veerkracht in de hele Europese Unie om de voedselzekerheid te vergroten

\begin{tabular}{|c|c|}
\hline Sterke punten & Zwakke punten \\
\hline $\begin{array}{l}\text { - Productieomstandigheden, infrastructuur } \\
\text { - Opleidingsniveau, kennisnetwerk } \\
\text { - Stabiel hoog inkomen laatste vijf jaar } \\
\text { - Innovatief vermogen } \\
\text { - Veerkracht } \\
\text { - Hoge productiviteit per ha } \\
\text { - Sterke vermogenspositie maakt bedrijven weerbaar }\end{array}$ & $\begin{array}{l}\text { - Hoge kostprijs als gevolg van dure grond en arbeid } \\
\text { - Afhankelijkheid van (fossiele) energie } \\
\text { - Tekort aan goede arbeidskrachten/Afhankelijkheid van } \\
\text { buitenlandse arbeidskrachten } \\
\text { - Grote verschillen tussen bedrijven in inkomen en } \\
\text { rentabiliteit } \\
\text { - Onderhandelingspositie in de keten zwak } \\
\text { - Sterke vermogenspositie bemoeilijkt bedrijfsovernames } \\
\text { - Rendement op eigen vermogen en arbeid lager dan in } \\
\text { sectoren buiten de landbouw }\end{array}$ \\
\hline Kansen & Bedreigingen \\
\hline
\end{tabular}

\section{Sterktes}

Het gemiddeld inkomen van glasgroentebedrijven ligt de laatste vijf jaar boven de $€ 200.000$ (inkomen per onbetaalde arbeidskracht; agrimatie.nl).

Door de beter bedrijfsresultaten is de vermogenspositie verbeterd en daarmee de financiële weerbaarheid vergroot. De gemiddelde solvabiliteit bedroeg in 2019 67\%. In 2013 werd met 29\% het laagste punt bereikt (agrimatie.nl).

Niet van toepassing:

- het gezinsbedrijf is dominant.

- Hoge aandeel berekende kosten vergroot weerbaarheid.

In de glasgroentesector zijn er ook veel bedrijven met een rechtsvorm. Met meer vreemde arbeid is het aandeel berekende kosten ook geringer.

\section{Zwaktes}

Glasgroenteteelt is sterk afhankelijk van de inzet van energie voor verwarmen en belichten. Het belichten neemt nog in omvang toe en met name voor LED-belichting. Dit vraagt meer duurzame warmte en elektriciteit (zie doel d).

$\mathrm{Er}$ is een tekort aan goede arbeidskrachten. De bedrijven zijn steeds meer afhankelijk van buitenlandse arbeidskrachten. De beschikbaarheid aan arbeid neemt af, waardoor robotisering steeds meer in de belangstelling komt. 
Grote spreiding in inkomens en rentabiliteit tussen glasgroentebedrijven (zie agrimatie.nl). Hieraan liggen verschillende oorzaken ten grondslag. Wel betekent dit dat bedrijven verschillen in vermogen om te anticiperen op veranderingen in markt en om te verduurzamen.

\section{Kansen}

Inspelen op niches en op de vraag naar gezonde producten vanuit de toegenomen aandacht voor meer plantaardige producten.

Ook de opkomst van vertical farming of indoor farming nabij stedelijke gebieden biedt kansen voor niche producten en opkweekmateriaal. Dit zal voorlopig nog beperkt van omvang zijn (Ruijs en Splinter, 2019).

Het tekort aan (buitenlandse) arbeidskrachten vergroot de kansen voor robotisering van arbeidsintensieve processen.

Niet van toepassing:

- Vraag naar publieke diensten (nieuw GLB)

- Inzet Platform Multifunctionele Landbouw om knelpunten in ontwikkeling multifunctionele landbouw weg te nemen en ontwikkelruimte te creëren

Het GLB speelt geen rol in de glastuinbouw, het zelfde geldt voor multifunctionele landbouw.

\section{Bedreigingen}

\section{Bedrijfsovername}

Door de toenemende schaalomvang van bedrijven is de overname moeilijker door de grote kapitaalslast. Aan de andere kant is bij glasgroentebedrijven veel meer sprake van een rechtsvorm. Ook ontstaan er nieuwe vormen van ondernemen en ondernemingen. Voor de glastuinbouw is het aandeel bedrijven met een rechtsvorm 45\% (2019). De rechtspersoon wordt met name gekozen in intensieve, minder sterk grondgebonden sectoren, met relatief veel niet-gezinsarbeidskrachten. Bij een rechtsvorm is de aansprakelijkheid in te perken, zijn fiscale voordelen te behalen bij hoge bedrijfswinsten en zijn de financieringsmogelijkheden te vergroten (zie agrimatie.nl).

Niet van toepassing:

- Hoge grondprijs en arbeid belemmeren extensivering

- Inkomensondersteunende en stabiliserende werking toeslagen neemt verder af

Extensivering is geen onderwerp in de glasgroenteteelt.

Steun via het GLB in het inkomen van glasgroentetelers is beperkt en veranderingen hierin zijn daardoor in geringe mate een bedreiging. Voor de tuinbouw is het berekende aandeel van de GLBsteun in het totale inkomen uit tuinbouwbedrijf 3\% gemiddeld in de periode 2013-2017 (Berkhout et al., 2019). 
(b) Vergroten van de marktgerichtheid en van het concurrentievermogen, onder meer door beter te focussen op onderzoek, technologie en digitalisering;

SWOT-samenvatting subdoelstelling B - Vergroten van de marktgerichtheid en van het concurrentievermogen, onder meer door beter te focussen op onderzoek, technologie en digitalisering

\begin{tabular}{|c|c|}
\hline & \\
\hline $\begin{array}{l}\text { - Goede uitgangspositie logistiek, infrastructuur, organisatie } \\
\text { - Handelspositie omvangrijk } \\
\text { - Sterke Groei R\&D agribusiness, toename innovatief } \\
\text { vermogen } \\
\text { - Duurzame investeringen (bijna) op koers } \\
\text { - Beleid Topsectoren } \\
\text { - Innovaties in technieken, producten, processen } \\
\text { - Organisatievermogen, samenwerking en innovatiekracht } \\
\text { - sector } \\
\text { - Digitaliseringsontwikkeling }\end{array}$ & $\begin{array}{l}\text { - Grootschaligheid en intensiteit productie } \\
\text { - Wet van de remmende voorsprong: toenemende druk } \\
\text { afgelopen jaren op concurrentiepositie voor meerdere } \\
\text { sectoren } \\
\text { - Hoge wet- en regelgevingsdruk, deels bovenwettelijk, met } \\
\text { nauwelijks verwaarding van de extra kosten } \\
\text { - Hoge financieringslasten beperken } \\
\text { ontwikkelingsmogelijkheden (met name middengroep) }\end{array}$ \\
\hline
\end{tabular}

\section{Sterktes}

\section{Handelspositie}

De import en export kan niet weergegeven worden voor alleen glasgroenten. De Nederlandse export van kas- en vollegrondsgroenten bedroeg $€$ 7,3 miljard in 2019; de import was $€$ 2,7 miljard in 2019. Behalve Duitsland (32\%) is het Verenigd Koninkrijk (12\%) een belangrijk afzetland. In totaal wordt 93\% van de Nederlandse tomaten afgezet binnen Europa. De import van groenten komt hoofdzakelijk uit Europa en met name uit Spanje (24\%) (Jukema et al., 2020).

\section{Duurzame investeringen}

De glasgroentensector heeft relatief gezien beperkt last gehad van vraaguitval ten gevolge van COVID-19. De verschuiving van out of home naar retail heeft geleid tot lagere prijzen in de markt. Producenten die zich hebben gespecialiseerd in schakels zoals horeca, foodservice of andere out of home consumptie zijn sterk geraakt door de crisis (onder andere gele courgette, speciale aubergines en cressen). Onzekerheid heerst over hoe de coronacrisis zich verder gaat ontwikkelen. Deze onzekerheid remt investeringen. De verwachting is dat de duurzame investeringen in 2020 niet zullen toenemen, hiervoor zijn in het voorjaar van 2020 door te veel glasgroentebedrijven, te veel verliezen geleden (Van der Meulen et al., 2020).

\section{Innovatief vermogen}

De meeste innovaties vinden plaats op glastuinbouwbedrijven (Van Galen en Van der Meer, 2020). $30 \%$ van de glastuinders behoorde tot de innovatoren $(10 \%)$, de vroege volgers $(7 \%)$ of de late volgers $(13 \%)$. Hierbij is geen onderscheidt gemaakt tussen glasgroeten en sierteelt onder glas. 


\section{Organisatie}

De meeste glasgroentetelers zijn aangesloten bij telersverenigingen of producentenorganisaties, zoals Growers United, Harvest House en Oxin growers (fusie van Best of Four en Van Nature). Het overgrote deel van de afzet gaat naar de groothandel en supermarkten via bemiddeling. Een klein deel belandt rechtstreeks of via handelsbedrijven bij de foodservice en grootverbruikers in Nederland (Bremmer et al., 2019).

\section{Zwaktes}

Hogere wet- en regelgevingsdruk kan meestal nog niet worden verwaard en leidt nog weinig tot een betere prijsvorming.

\section{Kansen}

Het imago van de glasgroenteteelt is goed. Er zijn de afgelopen jaren geen incidenten geweest met betrekking tot bijvoorbeeld volksgezondheid die dat imago hebben geschaad.

Bedrijfssystemen met een duurzaamheidslabel, zoals 'On the way to PlanetProof (SMK)', vinden steeds meer opgang op glasgroentebedrijven om zich daarmee te onderscheiden in de markt.

Robotisering van teelthandelingen (bladplukken en oogsten) biedt goede mogelijkheden om het groeiende tekort aan arbeid deels in te vullen.

Digitalisering biedt in de toekomst goede mogelijkheden om autonoom en op afstand te telen in kassen in binnen- en buitenland. ${ }^{18}$

De transitie naar een meer plantaardig dieet is een positieve prikkel voor de glasgroente sector.

\section{Opmerking vanuit de sector wat betreft kansen}

Het goede imago en de uitgangspositie biedt ook kans voor een regiefunctie van internationale bevoorrading van de EU-retail.

\section{Bedreigingen}

De ontwikkeling en uitbreiding van kassen in het buitenland en met name Europa, mede met behulp van Nederlandse technologie en kennis, zet de concurrentiepositie van Nederlandse glasgroentetelers onder druk. Deze ontwikkeling wordt gevoed door de verdere lokalisering (local for local) en de behoefte minder afhankelijk te zijn van importen van vers voedsel (Ruijs en Splinter, 2019).

De Brexit kan nadelig zijn voor de export van glasgroenteproducten naar het Verenigd Koninkrijk door de extra administratieve lasten en de sterkere euro.

Wat betreft digitalisering constateert de Houtskool-SWOT onder meer dat het ontbreekt aan de prikkel bij de toeleveranciers en afnemers van boeren en tuinders om EDI (electronic data exchange) in te voeren en de papierstroom aan te vullen met EDI-stromen. Uitzondering hierop is de ontwikkeling van zaken als de hortifootprint (voor groente, fruit en sierteeltproducten) (Bremmer et al., 2019).

Vanuit de sector is in reactie hierop opgemerkt dat er in de keten wordt gewerkt aan zaken als hortifootprint en producentenpaspoort (ontsluiten keteninformatie). Grote bedrijven in de agrosector dringen ook aan op digitalisering.

De tuinbouwsector kampt met een tekort aan arbeidskrachten op alle niveau's, zowel lager als midden- en hoger kader.

Niet van toepassing: Import van goedkopere grondstoffen

${ }^{18}$ https://www.groentennieuws.nl/article/9223587/team-automatoes-wint-autonomous-greenhouse-challenge/ 


\section{(c) Verbeteren van de positie van de landbouwers in de waardeketen;}

SWOT-samenvatting subdoelstelling C Verbeteren van de positie van de landbouwers in de waardeketen

\begin{tabular}{|c|c|}
\hline Sterke punten & Zwakke punten \\
\hline $\begin{array}{l}\text { - Hoog kennis en opleidingsniveau } \\
\text { - Uitgebreid kennisnetwerk dat kan bijdragen } \\
\text { - Goed ondernemerschap } \\
\text { - Innovatiekracht } \\
\text { - Samenwerking in de vorm van coöperaties, } \\
\text { - belangenbehartiging } \\
\text { - Efficiënte Logistiek } \\
\text { Opkomst korte ketens }\end{array}$ & $\begin{array}{l}\text { - Onderhandelingspositie in de keten } \\
\text { - Beperkt aandeel in consumenteneuro } \\
\text { - Import deels van andere kwaliteit, moeilijk mee te } \\
\text { concurreren op prijs } \\
\text { - Afname organisatiegraad/lidmaatschap in } \\
\text { producentenorganisaties }\end{array}$ \\
\hline Kansen & Bedreigingen \\
\hline $\begin{array}{l}\text { - Ondersteuning vanuit beleid (nationaal en provinciaal) } \\
\text { - Versterking band teler-burger via nieuwe } \\
\text { bedrijfsvormen/verdienmodellen } \\
\text { - Belangstelling kwaliteitsproducten stijgt, met name voor } \\
\text { gezonde producten } \\
\text { - Belonen van duurzaamheidsprestaties door (verwerkers } \\
\text { - } \text { - Met producentenorganisaties rol in de keten versterken } \\
\text { - Social media (verbinding stad-land, korte ketens) } \\
\text { - Nieuwe regelgeving om oneerlijke handelspraktijken } \\
\text { - tegen te gaan } \\
\text { kigitalisering biedt ondernemerschap kansen (in korte }\end{array}$ & $\begin{array}{l}\text { - Groei van korte ketens/niches kan leiden tot een druk op } \\
\text { de prijs } \\
\text { - Wet- en regelgeving kan kleine vernieuwende } \\
\text { ondernemers dwarsbomen } \\
\text { - Handelsverdragen met landen met minder } \\
\text { regels/wetgeving kunnen leiden tot ongelijk speelveld }\end{array}$ \\
\hline
\end{tabular}

\section{Sterktes}

Producenten werken samen in steeds grotere productenorganisaties (zie recente fusie van Best of Four en Van Nature), waarbij ook vestigingen in het buitenland voorkomen. Hierdoor zijn ze interessanter voor groothandel en supermarkten door jaarrondaanbod van een breder scala aan producten.

Niet van toepassing:

- Dichtbij afzetmarkt - kleine afstand stad/land

- Groei multifunctionele landbouw, met Boer-burger contact

In de glasgroenteteelt speelt dit een ondergeschikte rol.

\section{Zwaktes}

De onderhandelingspositie in de keten is nog steeds niet sterk, mede door de concurrentie uit andere (Zuid-)Europese landen. Telers zijn nog vooral prijsnemers.

Bedrijven die direct leveren aan de foodservice zijn kwetsbaar gebleken in 2020 ten gevolge van de Covid-19. Omschakelen naar het retailkanaal bleek niet in alle gevallen snel en goed mogelijk.

Door de toegenomen administratieve lasten om het risico van onjuiste toepassing van de GMO-regels te voorkomen met financiële risico's als gevolg en de wijziging in subsidiemogelijkheden in 2016 maken producentenorganisaties minder gebruik van EU-subsidies dan waar zij aanspraak op zouden kunnen maken. Ook is er een afname van erkende producentenorganisaties.

Recente cijfers over het aandeel van de productie dat wordt afgezet via erkende producentenorganisaties zijn nog in bewerking. De indruk is dat het aandeel is gedaald.

\section{Kansen}

Het onderscheiden op kwaliteit, duurzame productiewijze en leveringszekerheid biedt nog steeds goede kansen voor glasgroentebedrijven. De bereidheid om duurzaamheidsprestaties van 
teeltbedrijven te willen belonen (true pricing) komt steeds meer in zicht. Aandacht voor gezonde producten vanuit volksgezondheidsoptiek zal verder toenemen en kansen bieden voor verse kasgroenten (Ruijs en Splinter, 2019; ACCEZ, 2020).

Nieuwe bedrijfsvormen en verdienmodellen bieden kansen om de band tussen teler en burger te versterken. Hierbij kan gedacht worden aan korte ketens, zoals levering van verspakketten (onder andere Hello Fresh).

Digitalisering biedt kansen in de teelt, maar ook in de keten voor een efficiënte vraag gestuurde logistiek.

Niet van toepassing:

- Platform Multifunctionele Landbouw.

\section{Bedreigingen}

Ongelijk speelveld kan ontstaan door handelsverdragen met landen met minder regels. Daarnaast kunnen geopolitieke spanningen de export (en prijzen) van glasgroenten nadelig beïnvloeden.

Niet van toepassing:

- In dunner bevolkte regio's minder perspectief voor korte ketens. 


\section{(d) Bijdragen tot matiging van en aanpassing aan klimaatverandering en tot duurzame energie;}

SWOT-samenvatting subdoelstelling D Bijdragen aan mitigatie en adaptatie aan klimaatverandering en leveren van een bijdrage aan een duurzame energieproductie

\begin{tabular}{|c|c|}
\hline Ster & \\
\hline $\begin{array}{l}\text { - Veel mogelijkheden voor klimaatmitigatie en -adaptatie } \\
\text { - Publiek-private samenwerking om klimaatopties toe te } \\
\text { passen die in te passen zijn in de bedrijfsvoering } \\
\text { - Kennis om te innoveren } \\
\text { - Toepassing duurzame energie } \\
\text { - Initiatieven van ketenpartijen }\end{array}$ & $\begin{array}{l}\text { - Goedkope fossiele brandstoffen vertragen transitie } \\
\text { - Toepassing van wind- en zonne-energie is nog afhankelijk } \\
\text { van subsidies } \\
\text { - Beperking Uitstoot broeikasgassen ligt achter op schema }\end{array}$ \\
\hline Kansen & Bedreigingen \\
\hline $\begin{array}{l}\text { - (Onderzoek naar) Nieuwe en innovatieve } \\
\text { bedrijfssystemen } \\
\text { - (Onderzoek naar) Energiebesparing op bedrijven en in de } \\
\text { keten (duurzaamheidsprogramma's) } \\
\text { - Initiatieven van het bedrijfsleven } \\
\text { - Koploper worden in klimaatneutrale land- en tuinbouw }\end{array}$ & $\begin{array}{l}\text { - Business as usual in beleid en praktijk } \\
\text { - Beschikbaarheid van externe } \mathrm{CO}_{2} \\
\text { - Doorgaande klimaatverandering (m.n. klimaatextremen } \\
\text { met toenemend risico op opkomst/uitbraak van (nieuwe) } \\
\text { ziekten en plagen naast extreem weer } \\
\text { - Tekort aan goed gietwater }\end{array}$ \\
\hline
\end{tabular}

- Beperking wateroverlast met inzet bassins en andere vormen van waterberging

Dit onderdeel geldt voor de glastuinbouw als geheel, op het niveau van glasgroente zijn geen data voorhanden over het gebruik van (duurzame) energie en $\mathrm{CO}_{2}$-uitstoot.

\section{Sterktes}

In de glastuinbouw zijn veel mogelijkheden en initiatieven voor energiebesparing en $\mathrm{CO}_{2}$ emissiereductie. Dit wordt mede gestimuleerd door het PPS programma Kas als Energiebron van overheid en tuinbouwbedrijfsleven. Energiezuinige teeltconcepten, inzet van hernieuwbare energie, LED-belichting, etc. dragen bij aan de verdere verduurzaming van de sector.

Het aandeel duurzame energie in het totaal energiegebruik van de glastuinbouw bedraagt in 2019 $9,4 \%$ en is sinds 2012 sterk gestegen. Voor het eerst ligt het aandeel duurzame energie boven het landelijk aandeel. Het gebruik van duurzame energie bestond voor $87 \%$ uit warmte en $13 \%$ uit elektriciteit (Velden en Smit, 2020).

\section{Zwaktes}

De $\mathrm{CO}_{2}$-emissie is de laatste vijf jaar vrij stabiel en bedroeg in 2019 5,9 Mton en lag daarmee 1,3 Mton boven het actuele doel voor 2020 (4,6 Mton). In 2019 nam de $\mathrm{CO}_{2}$-emissie toe door een toename van het areaal glastuinbouw en de toename van de verkoop van elektriciteit en afname van de inkoop van niet-duurzame warmte (Velden en Smit, 2020).

Niet van toepassing:

- Teelt biomassa kan niet concurreren met teelt akkerbouwgewassen.

- Belemmeringen op het vlak van afval- en mestwetgeving staan hergebruik van stoffen in de weg.

\section{Kansen}

Het streven naar een klimaatneutrale glastuinbouw in 2050 wordt via het programma Kas als Energiebron gestimuleerd. De sector heeft deze ambitie verlegd naar 2040.

Toepassing van energiezuinige teeltconcepten en inzet van duurzame warmte (onder andere geothermie) en duurzame elektriciteit bieden nog volop kansen. De energiemarkt (prijzen) bepaalt deels hoe snel duurzame energie opschaalt.

Het vergroten van bassins en andere vormen van (collectieve) waterberging, waaronder met andere ruimtegebruikers, kan de wateroverlast bij extreme regenval beperken. 


\section{Bedreigingen}

Voor verdere $\mathrm{CO}_{2}$-emissiereductie zijn enkele beleidsmatige knelpunten gesignaleerd die aandacht vragen (Velden en Smit, 2020).

In het Klimaatakkoord zijn voor de glastuinbouw ambitieuze doelen afgesproken om toe te werken naar klimaatneutrale teelt. Om dit te bereiken is elektrificatie noodzakelijk, met als randvoorwaarde dat duurzame warmtebronnen en externe $\mathrm{CO}_{2}$ worden benut. De prikkels om deze transitie te faciliteren staan verkeerd en de $\mathrm{CO}_{2}$-reductie stagneert. De verhoging van de ODE op elektriciteit in de 3e schijf is hiervan een voorbeeld, waardoor elektriciteit voor de tuinder een stuk duurder is dan het gebruik van een gasgestookte WKK. Ook de stimulering van het gebruik van aardwarmte, restwarmte en externe $\mathrm{CO}_{2}$ vergt grote investeringen, waar de kaders en subsidieregelingen nog in ontwikkeling zijn. Dit maakt het voor tuinders onvoorspelbaar of investeringen in de klimaattransitie economisch haalbaar zijn.

De toenemende vraag naar duurzame warmte leidt tot een aparte vraag naar externe $\mathrm{CO}_{2}$ als meststof voor de teelt. Dit laatste is bekend, maar vraagt extra aandacht in onderzoek en ontwikkeling.

Klimaatverandering leidt ook tot een hogere frequentie van klimaatextremen, zoals droogte, neerslag, warmte, etc. Langdurige droogte kan leiden tot een verminderde beschikbaarheid van goed gietwater. Hoge buitentemperaturen in de zomer kunnen leiden tot productie- en kwaliteitsverlies. Tevens kunnen klimaatextremen leiden tot een uitbraak van nieuwe plagen en plantenziekten met productieen kwaliteitsverlies tot gevolg.

Niet van toepassing:

- Toenemende concurrentie om de grond (ruimteclaims). 


\section{(e) Bevorderen van duurzame ontwikkeling en efficiënt beheer van natuurlijke hulpbronnen zoals water, bodem en lucht;}

SWOT-samenvatting subdoelstelling E Bevorderen van duurzame ontwikkeling en efficiënt beheer van natuurlijke hulpbronnen, zoals water, bodem en lucht

\begin{tabular}{|c|c|}
\hline Sterke punten & Zwakke punten \\
\hline $\begin{array}{l}\text { - Efficiënte productie per eenheid product } \\
\text { - Waterefficiënte teelt (recirculatie) } \\
\text { - Geïntegreerde teelt (IPM) } \\
\text { - Milieudruk grond en oppervlaktewater met } \\
\text { gewasbeschermingsmiddelen, stikstof en fosfaat is stabiel } \\
\text { tot afgenomen } \\
\text { - Initiatieven in sector en keten } \\
\text { om milieubelasting productie terug te brengen } \\
\text { - Veel kennis in sectoren en ketens om de milieubelasting } \\
\text { van natuurlijke hulpbronnen te verminderen } \\
\text { werken aan verduurzaming }\end{array}$ & $\begin{array}{l}\text { - Nog niet alle milieudoelstellingen zijn gehaald, vergt ook } \\
\text { nog veel inspanning } \\
\text { - Te veel focus op enkelvoudige doelstellingen } \\
\text { - Enkele milieuproblemen zijn meer gebaat bij een } \\
\text { regionale aanpak dan bij de huidige generieke aanpak } \\
\text { (water en energie/ } \mathrm{CO}_{2} \text { ) } \\
\text { - Kosten verduurzaming niet altijd uit de markt te halen } \\
\text { - Onvoldoende fytosanitaire kennis/bewustzijn } \\
\text { producenten }\end{array}$ \\
\hline
\end{tabular}

- Visie Kringlooplandbouw biedt een wenkend perspectief voor systeemverandering en kan als katalysator werken

- Waterberging op gebiedsniveau met andere sectoren

\section{Sterktes}

De milieudruk van grond en oppervlaktewater is minder doordat teelten steeds meer in gesloten systemen plaatsvinden, door maximaal hergebruik van drain/drainagewater en lozing van afvalwater onderhevig is aan de zuiveringsplicht.

De teelt van glasgroenten vindt hoofdzakelijk geïntegreerd plaats (Integrated Pest Management). Wel is continue aanpassing nodig voor nieuwe ziekten en plagen. Ook blijft uit oogpunt van voedselveiligheid of bovenwettelijke eisen van retailers inzet en monitoring van nuttige insecten, etc. noodzakelijk.

De inzet van biologische bestrijding tegen insecten in de glasgroentesector is wijd verbreid. Bedrijven passen alleen ter correctie chemische bestrijding toe. Biologisch teelt komt nog in beperkte mate voor en vooral bij tomaten (Bremmer et al., 2019).

Sterk punt is de collectieve aanpak van diverse partijen om kennis te genereren en kennis te delen. Dit vergroot de innovatiekracht van bedrijven en de sector.

\section{Zwaktes}

Hoewel glasgroenten voornamelijk in gesloten systemen worden geteeld, vinden er nog altijd (incidentele) lozingen op het oppervlaktewater plaats.

Integrale teelt in gesloten systemen is een sterkte binnen de glastuinbouw. Het fytosanitaire bewustzijn en kennis bij telers is echter een aandachtspunt, zoals ten aanzien van het ToBRFV virus bij tomaat. Welke ziekten en plagen komen in Nederland, en specifiek in de regio, voor en welke maatregelen kan de teler nemen om insleep op het eigen bedrijf en verspreiding naar andere bedrijven te voorkomen. De teler heeft een grote rol bij vroegtijdige signalering en passende maatregelen op het eigen bedrijf en richting ketenpartners en tuinders in de omgeving. 


\section{Kansen}

De verduurzaming blijft doorgaan door de ontwikkeling van nieuwe (laagrisico)middelen, technieken en bedrijfssystemen. Met nieuwe middelen worden ook groene middelen bedoeld, zoals nieuwe biologische bestrijders (onder andere nieuwe insecten voor de bestrijding van plagen).

Hoewel de teelt van glasgroenten al in redelijke mate aan kringlooplandbouw voldoet, liggen vooral op het terrein van afvalstromen nog kansen voor verwaarding.

Door de klimaatverandering zullen droge en natte periodes vaker optreden. In de zomer kunnen daardoor tekorten ontstaan in de watervoorziening. Op gebiedsniveau liggen mogelijk kansen om het regenwater bij hevige regenval in samenwerking met andere sectoren te bufferen en te bergen. De maatschappelijke baten van wateroverlast moeten dan wel tot een vergoeding van deze dienst leiden. Deze kans is voor de langere termijn. Op de korte termijn liggen er kansen voor de rainlevelr (www.rainlevelr.com), waarbij telers in hun bassin ruimte maken vóór een zware bui om daarmee droge voeten te houden.

Daarnaast zijn er meer kansen op watergebied, zoals benutting van (gezuiverd) effluent voor de gietwatervoorziening.

\section{Bedreigingen}

Langdurige droogte kan de voorziening van kwalitatief goed water in gevaar brengen. Als kwalitatief minder water wordt gebruikt, treedt zoutophoping in gesloten teeltsystemen plaats en zal eerder water moeten worden geloosd.

In een aantal gebieden wordt grondwater opgepompt en via omgekeerde osmose gezuiverd voor toepassing als gietwater. Het zogenaamde brijn wordt vervolgens weer teruggebracht in de bodem. Naar verwachting zal op termijn het terugbrengen van brijn worden verboden. Toepassing van omgekeerde osmose wordt niet zonder meer toegestaan als het brijn kan worden afgevoerd, omdat daarvoor andere/nieuwe wetgeving nodig is.

Snelle uitfasering van middelen kan een bedreiging vormen als er (nog) geen goede alternatieven zijn.

Niet van toepassing:

- Noodzaak tot aanpassing grondgebruik vanwege klimaatverandering.

- Verzilting en verslemping groeiend probleem.

- Grote gevolgen van de rechterlijke uitspraak inzake het Programma Aanpak Stikstof en de aanvullende wetgeving. 
(f) Bijdragen tot de bescherming van de biodiversiteit, versterken van ecosysteemdiensten en in stand houden van habitats en landschappen.

SWOT-samenvatting subdoelstelling F Bijdragen aan de bescherming van de biodiversiteit, het versterken van ecosysteemdiensten en in stand houden van leefgebieden en landschappen

\begin{tabular}{ll} 
Sterke punten & Zwakke punten \\
- Voor de bedekte teelten is dit niet tot nauwelijks van & - Inpassing in het landschap \\
toepassing & Bedreigingen \\
Kansen & - Strengere voorwaarden aan nieuwbouw kassen vanwege \\
- Inpassing van kassen in landschappelijke omgeving in & inpassing in landschappelijke (open) gebieden \\
overleg met de omgeving & \\
\hline
\end{tabular}

Het assenkruis van de definitieve SWOT voor subdoelstelling $f$ is nauwelijks relevant voor de glasgroenteteelt, op een enkel hierboven genoemd punt na.

\section{Sterktes}

Voor de glasgroenteteelt is dit niet zozeer van toepassing.

\section{Zwaktes}

Uit oogpunt van landschappelijke schoonheid worden kassen door de meeste mensen als minder fraai betiteld.

\section{Kansen}

Nieuwe kassen zijn steeds hoger en groter in omvang. Hierdoor is een goede inpassing in de omgeving belangrijk, met name in 'open' gebieden (Bremmer et al., 2019). Overleg met de omgeving kan bezwaren voor een belangrijk deel wegnemen. Bij de inpassing kan gedacht worden aan kruidenrijk, grasstroken, etc.

De inzet van biologische bestuivers en bestrijders is samen met het met de natuur telen een positief element om maatschappelijke waardering te krijgen.

\section{Bedreigingen}

Aanvullende maatregelen kan nieuwbouw van kassen beperken uit oogpunt van landschappelijke inpassing. 


\subsection{Referenties}

ACCEZ (2020). Bloeien als bestemming. Vier toekomstscenario's voor het Nederlandse tuinbouwcluster.

Berkhout, Petra, Jakob Jager en Bert Smit (2019). Inkomenseffecten van de GLB-aanpassingen per 2020; Een quick scan. Wageningen, Wageningen Economic Research, Rapport 2019-114.

Bremmer, Johan, Bas Janssens, Marc Ruijs, Jan Benninga, Robert Stokkers, Gerben Splinter, Pepijn Smit en Linda Puister-Jansen (2019). Plantaardige ketens in beeld. Wageningen Economic Research 2019-069.

Galen, M. van, en R.W. van der Meer (2020). Innovatie in de land- en tuinbouw 2019. Wageningen Economic Research Rapport 2020-126.

Jukema G.D., P. Ramaekers en P. Berkhout (Red.) (2020). De Nederlandse agrarische sector in internationaal verband. Wageningen/Heerlen/Den Haag, Wageningen Economic Research en Centraal Bureau voor de Statistiek, Rapport 2020-001.

Meulen, H.A.B. van der, J.H. Wisman, J.H. Jager, G.D. Jukema en R.W. van der Meer (2020). Investeringsniveau duurzame productiemiddelen; Duurzaamheidsindicator (DP01) in de Rijksbegroting 2021. Wageningen, Wageningen Economic Research, Rapport 2020-103.

Ruijs, Marc en Gerben Splinter (2019). De kracht van glas; Hoe ziet het productassortiment voor de bedekte teelt er in 2050 in Nederland uit? Essay. Wageningen Economic Research, Den Haag.

Velden, N. van der, Smit, P. (2019). Energiemonitor van de Nederlandse glastuinbouw 2019. Wageningen Economic Research, rapport 2020-109, Wageningen 2020.

www.agrimatie.nl

www.groentennieuws.nl/article/9223587/team-automatoes-wint-autonomous-greenhouse-challenge/ www.ctgb.nl/onderwerpen/neonicotinoiden/geschiedenis-neonicotinoiden-in-het-kort

www.rainlevelr.com 


\subsection{Bijlage Indicatoren}

N.B. Alle data zijn op basis van Eurostat of nationale data als in Eurostat geen gegevens beschikbaar waren op deelsectorniveau.

Indicatoren C.12 tot en met C.34

Tabel C.12 Agrarische bedrijven

\begin{tabular}{lrrr} 
Aantal bedrijven naar omvang in ha & 2010 & 2015 & 201 \\
$<1$ ha & 702 & 146 & 468 \\
\hline $1-5$ ha & 244 & 395 \\
\hline $5-10$ ha & 98 & 219 & 102 \\
\hline $10-30$ ha & 7 & 140 \\
\hline $30-50$ ha & 5 & 14 \\
\hline$>50$ ha & 1.275 & 7 \\
\hline Total & 875 \\
\hline
\end{tabular}

Bron: Landbouwtelling

Tabel C.12 betreft het aantal gespecialiseerde glasgroentebedrijven. Vanaf 2010 neemt het aantal bedrijven verder af en zet de schaalvergroting door. Ditzelfde beeld treedt op als de omvang van bedrijven in SO (in euro) wordt uitgedrukt.

\begin{tabular}{|c|c|c|c|}
\hline Aantal bedrijven naar omvang in standaardopbrengst (SO) & 2010 & 2015 & 2020 \\
\hline SO: $3.000-25.000$ euro & 14 & 12 & 13 \\
\hline SO: $25.000-100.000$ euro & 94 & 76 & 46 \\
\hline SO: $250.000-500.000$ euro & 178 & 131 & 90 \\
\hline SO: $500.000-1.000 .000$ euro & 278 & 181 & 147 \\
\hline SO: $>3.000 .000$ euro & 143 & 149 & 205 \\
\hline Totaal & 1.243 & 936 & 862 \\
\hline
\end{tabular}

Een andere indicator is het aantal bedrijven met glasgroente (zie onderstaande tabel). De toename in 2019 en 2020 is waarschijnlijk het gevolg van extra aandacht van RVO voor de betrouwbaarheid van de cijfers.

\begin{tabular}{lllllr} 
Bedrijven met glasgroente & 2010 & 2015 & 2018 & 2019 & 2020 \\
Aantal bedrijven & 1.766 & 1.385 & 1.181 & 1.216 & 1.251 \\
\hline
\end{tabular}

Bron: Statline

Tabel C.13a Arbeidsinzet - in arbeidsjaareenheden

\begin{tabular}{|c|c|c|c|}
\hline Glasgroentebedrijven & 2010 & 2015 & 2020 \\
\hline Arbeidsjaareenheden (regelmatig en onregelmatig) regulier werkzaam & 7.822 & 5.394 & 6.364 \\
\hline Man & 5.396 & 3.058 & 3.877 \\
\hline Niet-reguliere arbeidsinzet & 7.103 & 7.646 & 10.714 \\
\hline
\end{tabular}

Tabel C.13b Arbeidsinzet: aantal arbeidsjaareenheden naar gezinsarbeid en vreemde arbeid

\begin{tabular}{lrrrrr} 
Glasgroentebedriven & 2010 & 2015 & 2018 & 2019 & 2020 \\
gezin & 2.122 & 1.457 & 1.194 & 1.177 & 1.179 \\
\hline niet gezin & 12.803 & 11.584 & 12.275 & 13.409 & 15.900 \\
\hline
\end{tabular}

Bron: Landbouwtelling. 
Tabel C.14 Leeftijdsopbouw agrarische bedrijfshoofden

\begin{tabular}{lrrr} 
Glasgroentebedrijven & 2010 & 2015 & 97 \\
$<40$ jaar (A) & 188 & 2020 \\
$>55$ jaar (B) & 320 & 84 \\
\hline Totaal & 1.257 & 321 \\
\hline ratio (A/B) & 59 & 948 & 34 \\
\hline
\end{tabular}

Bron: Landbouwtelling

Tabel C.15 Opleidingsniveau agrarische bedrijfshoofden

Niet voor glasgroente beschikbaar.

Tabel C.16 Aandeel bedrijven met een opvolger

\begin{tabular}{|c|c|c|c|}
\hline Glasgroentebedrijven & 2012 & 2016 & 2020 \\
\hline aandeel bedrijven met een opvolger & 106 & 59 & 46 \\
\hline aantal bedrijven met een bedrijfshoofd $>51$ jaar & 357 & 328 & 277 \\
\hline aandeel bedrijven met een opvolger & 30 & 18 & 17 \\
\hline
\end{tabular}

Bron: Landbouwtelling

Tabel C.17 Areaal landbouwgrond

\begin{tabular}{lrrr} 
Glasgroentebedrijven & 2010 & 2015 & 2020 \\
Areaal (ha) & 4.447 & 4.125 & 5.030 \\
\hline
\end{tabular}

Bron: Landbouwtelling

Het areaal tuinbouw onder glas op glasgroentebedrijven is vanaf 2015 sterk gestegen.

\begin{tabular}{|c|c|c|c|c|c|}
\hline Bedrijven met glasgroente & 2010 & 2015 & 2018 & 2019 & 2020 \\
\hline Areaal (ha) & 4.986 & 4.755 & 4.986 & 5.291 & 5.584 \\
\hline
\end{tabular}

Bron: CBS, Statline;

Het areaal op bedrijven met glasgroente lijkt in 2020 zeer sterk gestegen. Dit houdt mogelijk verband met de extra aandacht van RVO voor deze cijfers om de betrouwbaarheid te verbeteren. Dit cijfer hoort bij het aantal bedrijven met glasgroenten in $\mathrm{C} 12$.

C18

Geïrrigeerd areaal

Niet van toepassing

C19 Landbouw in Natura 2000 gebieden

Niet van toepassing

C20 Gebieden met natuurlijke handicaps

Niet van toepassing 
Niet van toepassing

C22

Veestapel

Niet van toepassing

C23

Veedichtheid

Niet van toepassing

Tabel C.24 Netto toegevoegde waarde per aje (in euro)

\begin{tabular}{lrrrr} 
& 2010 & 2015 & 2018 & 2019 \\
Glasgroentebedrijven & 50.678 & 67.987 & 53.608 & 58.008 \\
\hline
\end{tabular}

Tabel C.25 Inkomen uit bedrijf per oaje (in euro)

\begin{tabular}{lrrrr} 
& 2010 & 2015 & 2018 & 2019 \\
Glasgroentebedrijven & 113.554 & 332.987 & 233.872 & 283.086 \\
\hline
\end{tabular}

\section{C26}

Netto toegevoegde waarde per bedrijf

Niet beschikbaar voor glasgroente, alleen voor tuinbouw (kas en vollegrond).

C30

Handel (*)

Niet beschikbaar voor glasgroente.

Op basis van CBS data is de volgende inschatting gemaakt van de uitvoerwaarde en invoerwaarde van kasgroente producten.

Tabel Geschatte uitvoerwaarde en invoerde glasgroenten (miljard euro)

\begin{tabular}{lrrrrrr} 
Glasgroente & 2014 & 2015 & 2016 & 2017 & 2018 & 2019 \\
Uitvoerwaarde & 3,08 & 3,32 & 3,26 & 3,43 & 3,35 & 3,47 \\
\hline Invoerwaarde & 0,70 & 0,65 & 0,66 & 0,71 & 0,65 & 0,66 \\
\hline
\end{tabular}

Bron: CBS, bewerking Wageningen Economic Research.

C31

Toeristische infrastructuur

Niet van toepassing 
Tabel C.32 Areaal biologische landbouw en aandeel areaal biologische landbouw op totale areaal glasgroente

\begin{tabular}{|c|c|c|c|c|c|}
\hline \multirow[t]{2}{*}{ Aantal hectares (cultuurgrond) } & \multicolumn{5}{|c|}{ Glasgroentebedrijven } \\
\hline & 2015 & 2018 & & & 2020 \\
\hline Totaal areaal biologisch plus in omschakeling & 73 & 161 & & & 141 \\
\hline Areaal in omschakeling & 1 & 8 & & & 8 \\
\hline Totaal areaal glasgroente & 6.384 & 5.103 & & & 6.410 \\
\hline Totaal areaal biologisch plus in omschakeling & & 1,1 & 3,1 & 2,7 & 2,2 \\
\hline Areaal biologisch & & 1,1 & 3,0 & 2,5 & 2,1 \\
\hline Areaal in omschakeling & & 0,0 & 0,2 & 0,2 & 0,1 \\
\hline Totaal areaal glasgroente & & 100 & 100 & 100 & 100 \\
\hline
\end{tabular}

Bron: Landbouwtelling

Tabel C.33 Intensieve landbouw, aandeel areaal met hoge input (>350 euro aan input van kunstmest, voer en pesticiden /ha)

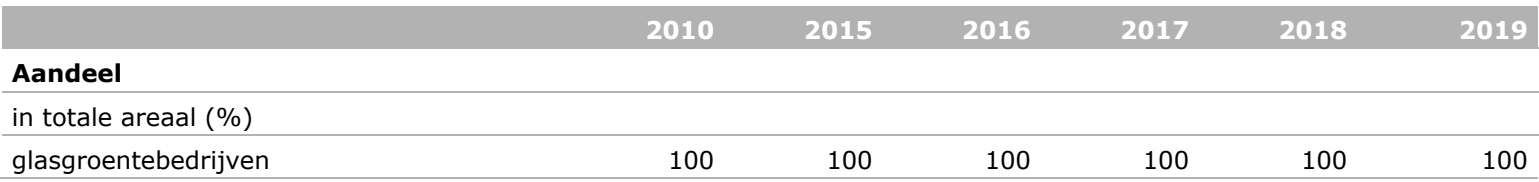

Bron: Bedrijveninformatienet Wageningen Economic Research

C34

Waarde van de productie in het kader van kwaliteitsschema's

Niet beschikbaar voor glasgroente.

Indicatoren C.35-C.48

C35 Boerenlandvogels index $(F B I)(*)$

Niet van toepassing

C36 Percentage van EU-beschermde soorten en leefgebieden gerelateerd aan landbouw

Niet van toepassing

C37

Watergebruik (*)

Niet beschikbaar.

Deze indicator is voor glasgroente wat minder relevant, omdat het grootste deel afkomstig is van regenwater dat wordt opgevangen. Het gietwater wordt zo lang mogelijk hergebruikt. Voor substraatteelten gaat dit makkelijker dan voor teelten in de grond.

\section{C38}

Waterkwaliteit

Niet beschikbaar voor glasgroente.

C39

Gehalte aan organische stof in bouwland

Niet beschikbaar. 
Niet van toepassing.

C41 Productie van duurzame energie door de landbouw en bosbouwsector

Niet van toepassing.

Tabel C.42 Energiegebruik in de landbouw, bosbouw en voedingsindustrie

Niet beschikbaar voor glasgroente.

Voor de glastuinbouw monitort Wageningen Economic Research het energiegebruik. Dit omvat het totale areaal van groente, fruit en sierteelt onder glas.

\begin{tabular}{lrrrrr} 
Energiesoort a),b) & 2010 & 2015 & 2017 & 2018 & $2019 \mathrm{~V}$ \\
Duurzame energie (PJ) & 2,4 & 4,9 & 6,7 & 7,4 & 10,0 \\
\hline Totaal energie (PJ) & 127,1 & 99,4 & 101,1 & 100,8 & 106,8 \\
\hline Totaal fossiel (miljoen $\mathrm{m}^{3}$ ) & 4.502 & 3.213 & 3.214 & 3.175 & 3.296 \\
\hline
\end{tabular}

a) totale glastuinbouw; b) niet temperatuur gecorrigeerd.

Bron: Velden en Smit, 2020.

Het duurzame energiegebruik is gestaag gestegen. Het totaal energiegebruik en het totaal fossiel energiegebruik is vanaf 2010 gedaald, maar is de laatste jaren weer wat toegenomen. Voor meer toelichting, zie bij doel d (Bijdrage aan matiging van en aanpassing aan klimaatverandering).

De glasgroentebedrijven hebben een substantieel aandeel in het energiegebruik.

Tabel C.43 Uitstoot broeikasgassen

Niet beschikbaar voor glasgroente.

Voor de glastuinbouw monitort Wageningen Economic Research de $\mathrm{CO}_{2}$-emissie. Dit omvat de groente, fruit en sierteelt onder glas.

\begin{tabular}{lccccc}
$\begin{array}{l}\mathrm{CO}_{2} \text {-emissie } \\
\text { totaal 1), 2) }\end{array}$ & 2010 & 2015 & 2017 & $2019 \mathrm{~V}$ \\
\hline Mton & 8,1 & 5,7 & 5,7 & 5,7 & 5,9 \\
\hline$\%$ van 1990 & 118 & 84 & 84 & 83 & 86 \\
\hline $\mathrm{kg} / \mathrm{m}^{2}$ & 78 & 62 & 63 & 63 & 61 \\
\hline
\end{tabular}

1) totale glastuinbouw; 2) niet temperatuur gecorrigeerd.

Bron: Velden en Smit (2020).

In 2019 is de $\mathrm{CO}_{2}$-emissie weer gestegen. Voor meer toelichting, zie bij doel d (Bijdrage aan matiging van en aanpassing aan klimaatverandering).

C44

Weerbaarheid bedrijven

Niet beschikbaar. 
Niet beschikbaar.

\section{C46 Ammoniakemissies (*)}

Niet van toepassing.

C47 Verkopen van antibiotica

Niet van toepassing.

Tabel C.48 Afzet van gewasbeschermingsmiddelen

\begin{tabular}{llccccc}
\hline Afzet van pesticiden (1.000 ton werkzame stof) & 2010 & 2015 & 2017 & 2018 & 2019 \\
\hline Glasgroentebedrijven & 0,06 & 0,04 & 0,05 & 0,07 & 0,05 \\
\hline Bron: Bedrijveninformatienet Wageningen Economic Research & & & & &
\end{tabular}




\section{SWOT-analyse deelsector vollegrondsgroente}

Robert Stokkers

N.B. deze analyse moet worden gelezen in samenhang met de SWOT-analyse op het niveau van de landbouwsector als geheel. Onderhavige analyse verbijzondert de SWOT-analyse waar nodig naar de deelsector in kwestie.

\subsection{Algemene beschrijving van de sector vollegrondsgroente}

Korte beschrijving van de sector ${ }^{19}$

De tuinbouwmatige vollegrondsgroenteteelt in Nederland betreft de productie in de open grond van groenten die bestemd zijn voor de versmarkt en in steeds grotere mate de snijderijen. ${ }^{20}$ De vollegrondsgroenteteelt vraagt meer arbeid, met name bij de oogst en bewerking, dan de akkerbouwmatige groenteteelt, die meer is gericht op de markt voor industriële verwerking. De tuinbouwmatige vollegrondsgroenteteelt in Nederland beslaat ongeveer 26.000 ha en vindt plaats op ongeveer 2.800 bedrijven (figuur 1) (agrimatie. $\mathrm{nl}$ ). Circa $50 \%$ van dit areaal wordt geteeld op circa 850 gespecialiseerde vollegrondsgroentebedrijven (C.12). De overige productie vindt vooral plaats op akkerbouwbedrijven, waar de laatste jaren een forse groei waarneembaar is van het areaal vollegrondsgroenten.

De belangrijkste gewassen zijn aardbei, asperges, bloemkool, broccoli, prei, sla, sluitkool en spruiten en deze zijn bestemd voor de versmarkt. Het zijn voornamelijk teelten in de open grond, zonder de bescherming van bijvoorbeeld een kas. Door middel van teeltondersteunende voorzieningen kan het productieseizoen worden vervroegd dan wel verlaat. Akkerbouwmatige teelten als ui, peen, slabonen en erwten behoren volgens de indeling die wordt gehanteerd door het CBS niet tot de tuinbouwmatige vollegrondsgroenten. Ui, peen en erwten behoren volgens de gemeenschappelijk marktordening voor groente en fruit wel tot de groente- en fruitsector. In deze SWOT-analyse hanteren we de CBSdefinitie.

De meeste productie vindt plaats in de provincies Noord-Brabant, Limburg, Noord- en Zuid-Holland en Flevoland. Zeventig procent van de productie wordt geëxporteerd, voornamelijk naar landen binnen de Europese Unie: Duitsland, Groot-Brittannië en Frankrijk zijn grote afzetmarkten. Internationaal zijn België, Frankrijk en Spanje belangrijke concurrenten, naast de lokale productie in de landen waar naar toe wordt geëxporteerd zelf.

\footnotetext{
${ }^{19}$ Deze tekst is vrijwel volledig afkomstig uit Bremmer et al. (2019), de data zijn geactualiseerd.

${ }^{20}$ Het is gebruikelijk onderscheid te maken naar bewerking, zoals snijden en verpakken waarbij de aard van het product niet verandert, en verwerking, zoals conserveren en invriezen, waarbij de aard van het product wel verandert.
} 


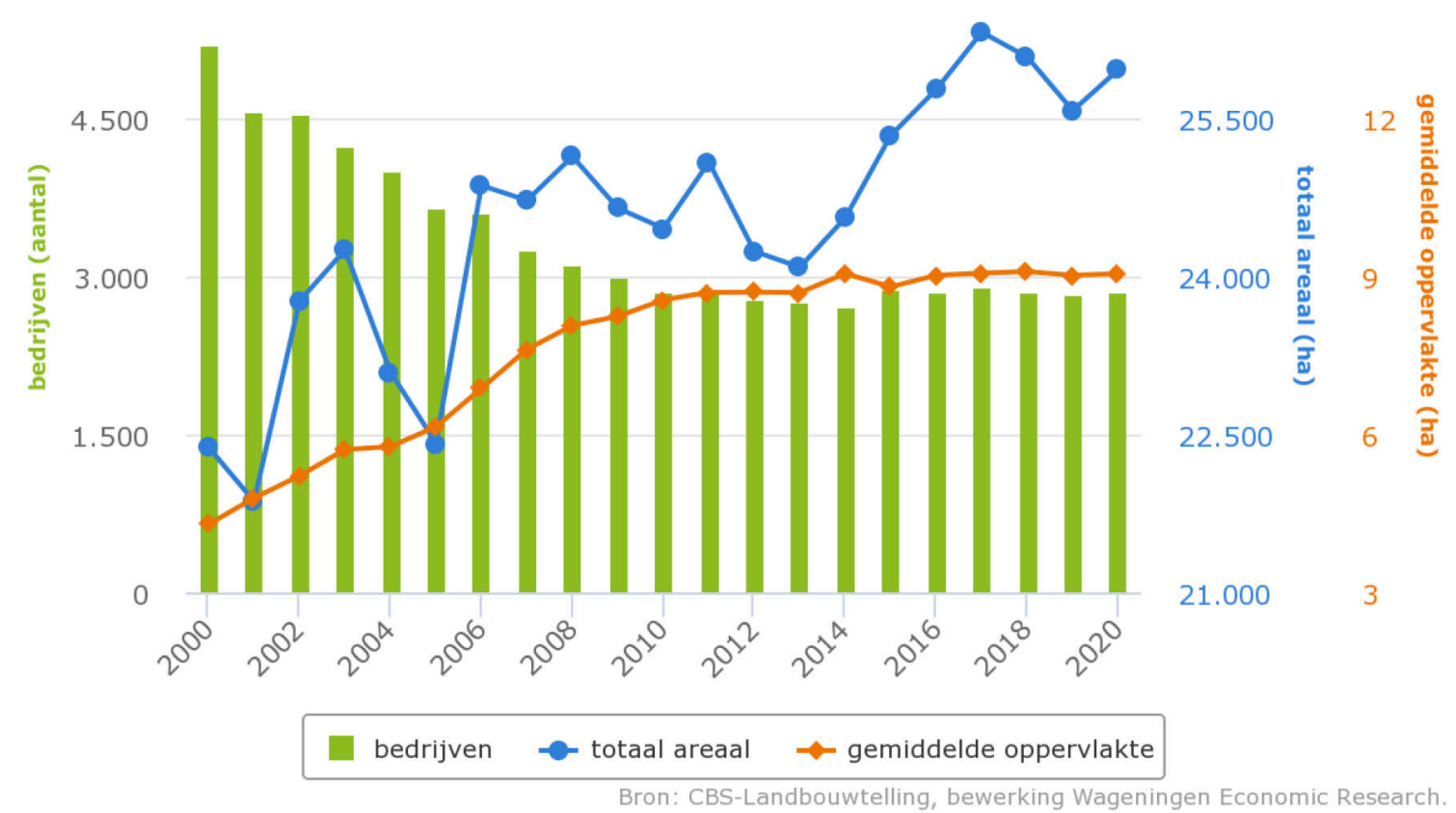

Figuur 1 Aantal bedrijven met opengrondsgroenten, areaal en areaal per bedrijf. N.B. cijfers kunnen afwijken van in de tekst genoemde, omdat hier alle bedrijven met opengrondsgroenten worden meegenomen, niet enkel de gespecialiseerde opengrondsgroentebedrijven

\section{Productiesysteem ${ }^{1}$}

Het merendeel van de tuinbouwmatige vollegrondsgroenten wordt daadwerkelijk geteeld in de open lucht en in de vollegrond zonder enige vorm van bedekking. Hierbij zorgen meerdere planttijdstippen voor een spreiding van de oogst over het seizoen. Door gebruik te maken van grondverwarming, bedekking met bijvoorbeeld vliesdoek of zwart plastic of zelfs blaastunnels is een vervroeging van de teelt mogelijk. Dergelijke teeltondersteunende maatregelen brengen veel extra kosten met zich mee en zijn met name rendabel bij relatief dure groenten als aardbeien en asperges.

Daarnaast zijn productiesystemen uit de grond in ontwikkeling, zoals de teelt in goten en sleuven of op water. Een heel bekend voorbeeld is de teelt op stellingen van aardbeien. Dergelijke productiesystemen zijn duurder, maar kunnen vele voordelen bieden op het gebied van een hogere opbrengst en oogstzekerheid, minder uitval door bodemziekten, minder emissie van gewasbeschermingsmiddelen en meststoffen naar het milieu en betere arbeidsomstandigheden. De nadelen van deze systemen liggen op het vlak van een hoger verbruik van materialen en energie en lagere natuur- en landschapswaarden.

Een vreemde eend in de bijt is de productie van witlof. De witlofpennen of -wortelen worden in toenemende mate geteeld op contract bij akkerbouwbedrijven. Na de oogst in het najaar worden de witlofwortelen door de witloftrekkers bewaard in koelcellen tot het moment van gebruik. De witloftrek vindt tegenwoordig vrijwel het gehele jaar plaats in cellen op veelal stromend water en in drie tot vier weken groeien uit de witlofwortelen de witlofkroppen voor menselijke consumptie.

\section{Aandeel biologisch}

Biologische groenten zijn het pioniersstadium inmiddels wel ontgroeid. Het aantal bedrijven met biologische vollegrondsgroententeelt is in de periode 2011-2017 gestegen van ongeveer 245 naar 300. Het relatieve aandeel van het totaal aantal bedrijven met biologische vollegrondsgroententeelt ligt al een aantal jaren rond de 10\%. De komkommerachtigen (onder andere courgette en pompoen) zijn in de periode 2011-2017 uitgegroeid tot meest geteelde vollegrondsgroenten met een areaal van 670 ha. De tweede en derde plaats worden ingenomen door sluitkool (onder andere witte en rode 
kool) met gemiddeld 240 ha en bloemkool met 195 ha. Het areaal biologische broccoli zit in de lift en bedraagt in 2017 ruim 180 ha. Het aandeel areaal biologische groenten in het totale areaal vollegrondsgroenten bedraagt naar schatting 5 tot $7 \%$. Veel van deze producten worden afgezet via de reguliere afzetkanalen ${ }^{1}$.

Uit de laatste cijfers over de ontwikkeling van het areaal biologisch blijkt dat dit in 20191.390 ha bedroeg op de vollegrondsgroentenbedrijven (zie bijlage 1, tabel C.32). ${ }^{21}$ Daarvan was 1.251 ha biologisch en 139 ha nog in omschakeling. Op het totale areaal vollegrondsgroente gaat het om een aandeel van 6,7\%. In vergelijking met 2015 is het areaal en het aandeel licht gedaald.

\section{Bedrijfsgrootte, opvolging, inkomen}

Evenals in de overige sectoren van de landbouw, is het aantal bedrijven met vollegrondsgroente gedaald de afgelopen jaren, de daling is het sterkste bij bedrijven met minder dan 30 ha (zie bijlage 1, tabel C.12).

Het aantal opvolgers ligt met $27 \%$ lager dan voor de totale land- en tuinbouw (zie bijlage 1 , tabel C.16).

De netto toegevoegde waarde tegen factorkosten (C.24), de beloning voor de inzet van de productiefactoren arbeid, grond en kapitaal, ligt gemiddeld wat lager dan in de andere sectoren van de land- en tuinbouw. Na aftrek van de betaalde factorkosten resteert het inkomen voor de ondernemer, dat wil zeggen de beloning van de inzet van eigen arbeid, kapitaal en grond (indicator C.25). Dit inkomen ligt op ongeveer hetzelfde niveau als voor de akkerbouw en de melkveehouderij.

\section{Netto toegevoegde waarde en werkgelegenheid opengrondstuinbouwcomplex}

Er zijn geen gegevens beschikbaar over de bijdrage van het vollegrondsgroentecomplex aan de netto toegevoegd waarde en de werkgelegenheid. Deze zijn er wel voor het opentuinbouwcomplex, waarvan de vollegrondsgroentesector onderdeel is.

Het opengrondstuinbouwcomplex is samengesteld uit de primaire bedrijven (groenteteelt in de volle grond-, fruitteelt-, bloembollenteelt- en boomkwekerijbedrijven; totaal 5.710 bedrijven in 2018), de groente- en fruitverwerkende industrie, de toeleveranciers en de distributiebedrijven. De bijdrage van de laatste twee is beperkt tot het deel dat deze sectoren aan de primaire opengrondstuinbouwbedrijven of de verwerkende industrie leveren.

De toegevoegde waarde van het opengrondstuinbouwcomplex bedroeg in 2018 - het meest recente jaar waarvoor de cijfers beschikbaar zijn - circa 4,1 miljard euro, het hoogste niveau sinds 2010. Ondanks de toename blijft het aandeel in het bruto binnenlands product (bbp) gelijk op 0,5\%. Ongeveer $15 \%$ van de toegevoegde waarde is te danken aan de verwerking van buitenlandse agrarische grondstoffen en de daarmee samenhangende toelevering en distributie. Van de toegevoegde waarde van het op binnenlandse agrarische grondstoffen gebaseerde deel (3,5 miljard euro) was $62 \%$ afkomstig van de primaire bedrijven. De absolute bijdrage van de primaire sector binnen het complex (2,1 miljard euro) is de laatste jaren licht gestegen. De droogte van 2018 leverde de vollegrondsgroentetelers een hogere omzet op. Het aandeel van de toelevering in de toegevoegde waarde van het op binnenlandse grondstoffen gebaseerde deel bedraagt circa $28 \%$; dat van verwerking en distributie komt op enkele procenten.

De totale werkgelegenheid van het opengrondstuinbouwcomplex is in 2018 met ongeveer 52.000 arbeidsjaren licht gestegen en bedroeg 0,7\% van de totale werkgelegenheid in Nederland. Ongeveer $62 \%$ van de werkgelegenheid van het op binnenlandse agrarische grondstoffen gebaseerde opengrondstuinbouwcomplex is toe te schrijven aan de primaire bedrijven. Dit is gelijk aan het aandeel in de toegevoegde waarde. De werkgelegenheid die samenhangt met de toelevering beloopt

${ }^{21} \mathrm{Bij}$ deze indicator gaat het om het totaal areaal cultuurgrond naar bedrijfstype. Dit is op de vollegrondsgroentebedrijven voor een groot deel tuinbouwmatige groenten, omdat $66 \%$ van de zogenaamde standaardopbrengst afkomstig moet zijn van tuinbouwmatige groenten om als vollegrondsgroentebedrijf te kunnen worden gekwalificeerd. Dit houdt in dat $33 \%$ uit andere producten kan bestaan, waaronder akkerbouwmatige groenten. 
$29 \%$ van het totaal en distributie en verwerking hebben een aandeel van respectievelijk 5 en $4 \%$ (agrimatie.nl).

\section{Handelspositie}

Het exportvolume van de belangrijkste tuinbouwmatige vollegrondsgroenten bedroeg in de periode 2010-2016 gemiddeld 462 miljoen kilo. Dit komt overeen met 70\% van het Nederlandse productievolume, maar is wel inclusief wederuitvoer. De belangrijkste exportproducten vormen de koolsoorten (inclusief bloemkool, broccoli, sluitkool en spruitkool) met een aandeel van 49\%, sla en witlof met een aandeel van $25 \%$ en prei met een aandeel van $11 \%$. Voor alle productgroepen geldt dat ongeveer $90 \%$ van de export zijn bestemming vindt in de landen van de Europese Unie. De belangrijkste landen zijn Duitsland, het Verenigd Koninkrijk en Frankrijk (Bremmer et al., 2019).

Het importvolume van de tuinbouwmatige vollegrondsgroenten bedroeg in de periode 2010-2016 gemiddeld 221 miljoen kilo. De belangrijkste importproducten vormen de koolsoorten (incl. bloemkool, broccoli, sluitkool en spruitkool) met een aandeel van $42 \%$, sla en witlof met een aandeel van $36 \%$ en aardbeien met een aandeel van $11 \%$. De import van vollegrondsgroenten is van groot belang als aanvulling op het Nederlandse productieseizoen en is voor ongeveer $90 \%$ afkomstig uit de landen van de Europese Unie, met name Spanje en Italië. Alleen asperges komen ook grotendeels van buiten de Europese Unie, onder andere uit Zuid-Amerika. De import en export van vollegrondsgroenten is sterk afhankelijk van het weer en de oogsten in Nederland en de rest van de Europese markt (Bremmer et al., 2019).

Onderstaande figuur geeft de export in kilo's van opengrondsgroenten.

\section{Export vanuit Nederland in kilo's (bron: $\mathrm{KCB} /$ GroentenFruit Huis)}

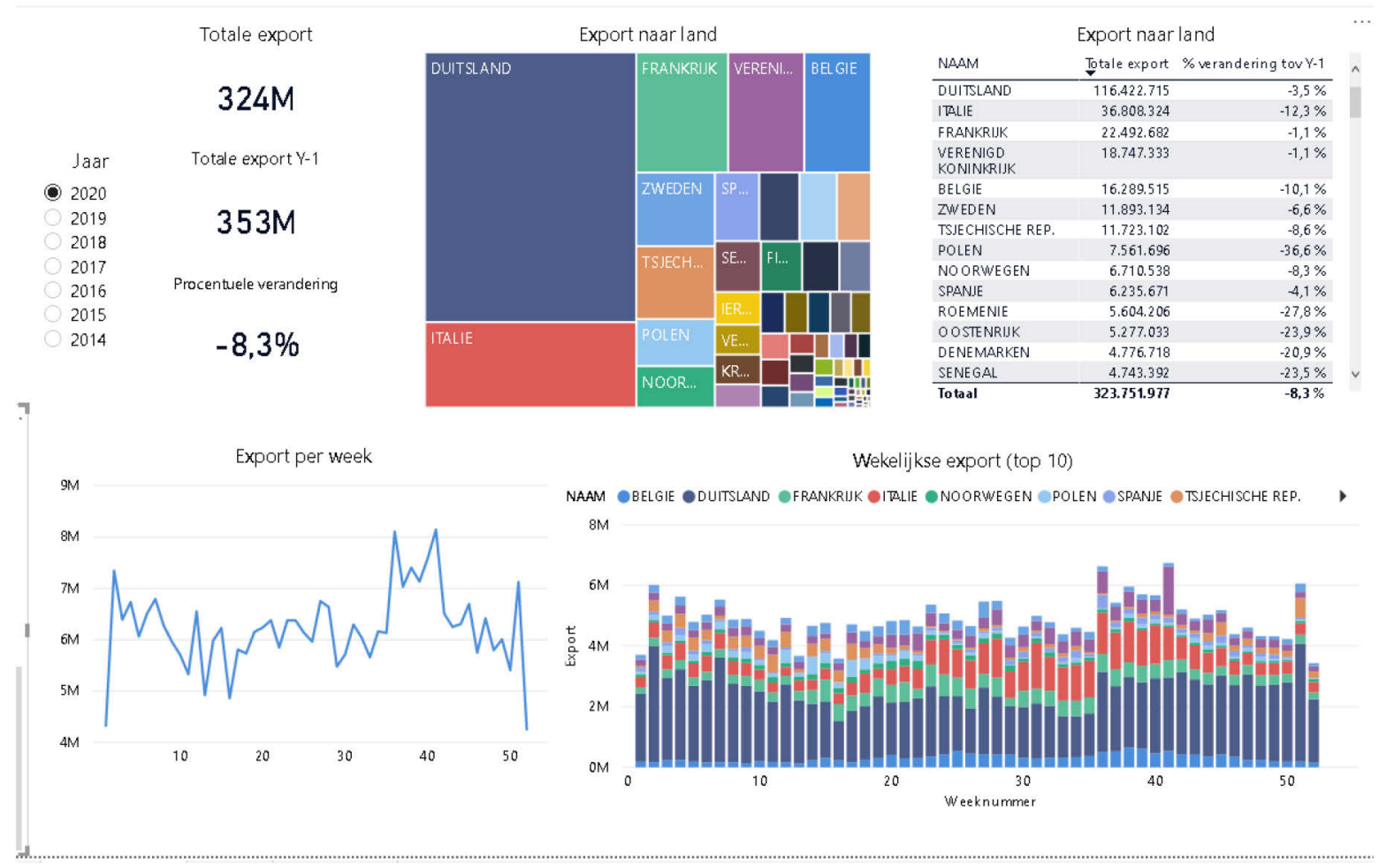




\subsection{SWOT-analyse per specifieke doelstelling}

\section{(a) Bieden van steun met het oog op een leefbaar landbouwinkomen en veerkracht in de hele Unie om de voedselzekerheid te vergroten;}

SWOT-samenvatting subdoelstelling A Bieden van steun met het oog op een leefbaar landbouwinkomen en veerkracht in de hele Europese Unie om de voedselzekerheid te vergroten

\begin{tabular}{|c|c|}
\hline Sterke punten & Zwakke punten \\
\hline $\begin{array}{l}\text { - Productieomstandigheden, infrastructuur } \\
\text { - Opleidingsniveau, kennisnetwerk } \\
\text { - Innovatief vermogen } \\
\text { - Veerkracht } \\
\text { - Hoge productiviteit per ha } \\
\text { - Sterke vermogenspositie maakt bedrijven weerbaar } \\
\text { - Gezinsbedrijf dominant } \\
\text { - Hoge aandeel berekende kosten vergroot weerbaarheid }\end{array}$ & $\begin{array}{l}\text { - Hoge kostprijs als gevolg van dure grond en arbeid } \\
\text { - Inkomens landbouw lager ten opzichte van vergelijkbaar } \\
\text { werk buiten de landbouw } \\
\text { - Merendeel van de huidige bedrijven in de land- en } \\
\text { tuinbouw is te klein om een marktconforme beloning voor } \\
\text { de inzet van eigen arbeid en kapitaal te realiseren } \\
\text { - Onderhandelingspositie in de keten zwak } \\
\text { - Werken buiten de landbouw is financieel aantrekkelijker } \\
\text { - Sterke vermogenspositie bemoeilijkt bedrijfsovernames } \\
\text { - Rendement op eigen vermogen en arbeid lager dan in } \\
\text { - Rectoren buiten de landbouw } \\
\text { Retail wil jaarrond productie afnemen }\end{array}$ \\
\hline Kansen & Bedreigingen \\
\hline $\begin{array}{l}\text { - Markt voor nieuwe bedrijfsvormen/verdienmodellen (korte } \\
\text { ketens, slimmere ketens, multifunctionele landbouw) } \\
\text { - Groenten en fruit van belang in transitie naar een meer } \\
\text { plantaardig dieet } \\
\text { - Sterke verstedelijking van het Nederlandse platteland } \\
\text { geeft kansen voor directe verbindingen met de stad via } \\
\text { het leveren van producten en diensten } \\
\text { - Taskforce Verdienvermogen (onderdeel } \\
\text { Kringlooplandbouw) bewaakt randvoorwaarde van een } \\
\text { redelijk inkomen } \\
\text { - Inzet Platform Multifunctionele Landbouw om knelpunten } \\
\text { in ontwikkeling multifunctionele landbouw weg te nemen } \\
\text { en ontwikkelruimte te creëren } \\
\text { - Aandacht voor het vergroten van veerkracht }\end{array}$ & $\begin{array}{l}\text { - Bedrijfsovername niet eenvoudig door kapitaalintensiteit } \\
\text { bedrijven } \\
\text { - Na bedrijfsovername is aantrekken vreemd vermogen } \\
\text { lastig gegeven zware financiering } \\
\text { - Hoge prijs grondprijs en arbeid belemmeren extensivering } \\
\text { - Financieringslasten bij overname } \\
\text { - Aantrekkingskracht werk buiten de sector, jonge boeren } \\
\text { kiezen bewust voor baan buiten de landbouw } \\
\text { (is deels ook een kans omdat het ruimte schept voor andere } \\
\text { bedrijven om door te groeien) }\end{array}$ \\
\hline
\end{tabular}

\section{Sterktes}

Niet van toepassing:

- hoge productiviteit per dier.

\section{Zwaktes}

Retail wil jaarrond productie afnemen, de Nederlandse teelt kan dat niet bieden.

\section{Kansen}

Niet van toepassing:

- Vraag naar publieke diensten (nieuw GLB). Dit speelt nauwelijks in de opengrondsgroenteteelt gegeven de hoge saldi per ha.

\section{Slimmere ketens}

ICT biedt steeds meer mogelijkheden voor het slim organiseren van ketens. Het gaat dan bijvoorbeeld om voorraadbeheer en het garanderen van productkwaliteit tot in het schap. Hoe beter de keten kan worden georganiseerd, hoe verser het product dat in de schappen ligt en hoe minder uitval er kan zijn. Dit kan ook leiden tot kostenbesparingen. 
Inspelen op niches

Het belang van direct door de ondernemer afgezette groenten neemt toe, maar het marktaandeel is (nog) zeer bescheiden. Het gaat om producten die veelal rechtstreeks naar de consument worden afgezet via boerenmarkten, boerderijwinkels en webwinkels (Bremmer et al., 2019). Onderzoek van Tacken et al. (2021) naar afzet van producten via de korte keten, geeft aan dat als korte ketens gedefinieerd worden als ketens waarbij er maximaal 1 schakel zit tussen boer/tuinder/visser en burger (de Europese definitie), daar in Nederland alleen boerderijwinkels, online verkoop door boeren en marktkooplui onder vallen. Het marktaandeel is nog geen $1 \%$ van de totale voedingsmiddelenmarkt in Nederland.

De Europese definitie is te smal is om de Nederlandse activiteiten in korte ketens te dekken (ibidem). Ook in de reguliere ketens in Nederland zitten soms maar twee schakels tussen boer en consument. De studie van Tacken et al. (2021) hanteert daarom een bredere definitie en gaat uit van een toeleveringsketen bestaande uit een beperkt aantal marktdeelnemers die streven naar samenwerking, plaatselijke economische ontwikkeling en nauwe geografische en sociale betrekkingen tussen producenten, verwerkers en consumenten, waarbij er geen of maximaal twee ketenpartijen tussen de boer en de consument aanwezig zijn en waarbij de boer als leverancier van het product herkenbaar is voor de consument. Op basis van deze definitie wordt het marktaandeel geschat tussen de 3 tot $4 \%$ (Tacken et al., 2021). Voor vollegrondsgroente geldt dat dit percentage vermoedelijk hoger ligt, harde cijfers ontbreken.

\section{Verbreding/multifunctionele landbouw}

Naast productniches, kan een ondernemer ook kiezen voor verbreding/multifunctionele landbouw als neventak. Ongeveer $25 \%$ van de Nederlandse boeren en tuinders pakt naast de akkerbouw, tuinbouw of veeteelt ook andere - maatschappelijke - activiteiten op als zorglandbouw, kinderopvang, boerderijeducatie, boerderijverkoop, natuurbeheer en/of recreatie (Meulen et al., 2019). In hoeverre vollegrondsgroentebedrijven hierbij betrokken zijn, is niet bekend. Het onderzoek van Meulen et al. maakt geen onderscheid naar bedrijfstypen.

Voor vollegrondsgroenteteeltbedrijven zijn activiteiten als zorglandbouw, boerderijeducatie (bijvoorbeeld koken met vergeten groenten) en boerderijverkoop (huisverkoop asperges en aardbeien, groenteboxen) voorbeelden van verbreding.

\section{Bedreigingen}

\section{Bedrijfsovername}

In de Landbouwtelling wordt eens in de vier jaar gevraagd of er een bedrijfsopvolger aanwezig is. Deze vraag wordt gesteld aan bedrijfshoofden van 50 jaar of ouder met een bedrijf zonder rechtspersoonlijkheid, zoals een eenmanszaak, maatschap, commanditaire vennootschap of vennootschap onder firma. Bij een bedrijfsvoering die uit meerdere personen bestaat, wordt gevraagd naar de leeftijd van het bedrijfshoofd met de grootste zakelijke en bedrijfsmatige verantwoordelijkheid in het bedrijf. Als de bedrijfshoofden evenveel verantwoordelijkheid hebben, dan wordt gevraagd naar de leeftijd van de oudste ondernemer.

In de vollegrondsgroenteteelt is het aandeel bedrijven met rechtspersoonlijkheid in de periode 20002016 gestegen van 3 naar 13\%. De toenemende belangstelling hiervoor heeft alles te maken met de schaalvergroting en daarmee gepaard gaande grotere vermogensbehoefte, evenals met het afdekken van persoonlijke risico's in het kader van de wettelijke aansprakelijkheid. Desalniettemin hebben de meeste bedrijven geen rechtspersoonlijkheid, maar als rechtsvorm een natuurlijke persoon. Dit biedt diverse fiscale voordelen, onder andere bij bedrijfsovername, maar daar staat veelal een persoonlijke verantwoordelijkheid tegenover.

Het aandeel bedrijven met als rechtsvorm een natuurlijke persoon en een bedrijfshoofd van 51 jaar of ouder is eveneens gestegen van 46 naar $55 \%$, waarvan het aantal bedrijven zonder opvolging is toegenomen van 31 naar $40 \%$. Kortom, in de vollegrondsgroenteteelt is er een veroudering van het ondernemersbestand en is de belangstelling voor bedrijfsopvolging afgenomen (Bremmer et al., 2019). 
Het aandeel van de steun via het GLB in het inkomen van vollegrondsgroentetelers is vermoedelijk beperkt. Gedetailleerde cijfers voor enkel de vollegrondsgroentetelers zijn niet voorhanden. Voor de tuinbouw, inclusief glastuinbouw, wel. Het berekende aandeel van de GLB steun in het totale inkomen uit bedrijf is 3\% gemiddeld in de periode 2013-2017 (Berkhout et al., 2019).

Gegeven het feit dat de saldi van vollegrondsgroentes hoog zijn en wel $€ 20.000$ per ha ${ }^{22}$ kunnen bedragen, is de basistoeslag van circa $€ 260$ per ha (circa $€ 380$ als de vergroeningsbetaling wordt meegerekend) van beperkt belang. Het lijkt aannemelijk dat - uitgaande van een toenemend aantal eisen dat wordt gesteld om in aanmerking te komen voor de basistoeslag (de zogenaamde verhoogde conditionaliteit) - het aantal ondernemers in de vollegrondsgroenteteelt dat een basistoeslag aanvraagt verder zal dalen.

Niet van toepassing:

- Ongelijk speelveld

Op de Nederlandse markt is er tijdens het Nederlandse productieseizoen niet of nauwelijks concurrentie, tijdens het Nederlandse productieseizoen wordt er nauwelijks geïmporteerd. In het voorjaar en najaar heeft de sector wel te maken met concurrentie van producten uit bijvoorbeeld Zuid-Europa.

Binnen de EU zijn de eisen aan de productie in principe gelijk, wel kunnen er verschillen zijn in de toepassing en toelating van gewasbeschermingsmiddelen. Voor Nederland geldt dat er meer emissiebeperkende maatregelen zijn, vanwege het vele oppervlaktewater. Andere landen hebben meer 'last' van droogte. Dit wil niet zeggen dat het speelveld ongelijk is, meer dat de fysieke productieomstandigheden uiteenlopen. Wat betreft toelating van gewasbeschermingsmiddelen, constateert de Tussenevaluatie van de nota Gezonde groei, duurzame oogst dat de harmonisatie van de toelating van middelen in de EU beter kan (PBL, 2019).

Concurrentie met producten van buiten de EU is er niet. Het merendeel van de vollegrondsgroente wordt binnen een beperkte afstand (voor Nederland is dat overwegend Nederland, Duitsland en het Verenigd Koninkrijk) afgezet.

\footnotetext{
${ }^{22}$ Ontleend aan de kwantitatieve informatie Akkerbouw en Vollegrondsggroenteteelt (KWIN-AGV, 2018). 
(b) Vergroten van de marktgerichtheid en van het concurrentievermogen, onder meer door beter te focussen op onderzoek, technologie en digitalisering;

SWOT-samenvatting subdoelstelling B - Vergroten van de marktgerichtheid en van het concurrentievermogen, onder meer door beter te focussen op onderzoek, technologie en digitalisering

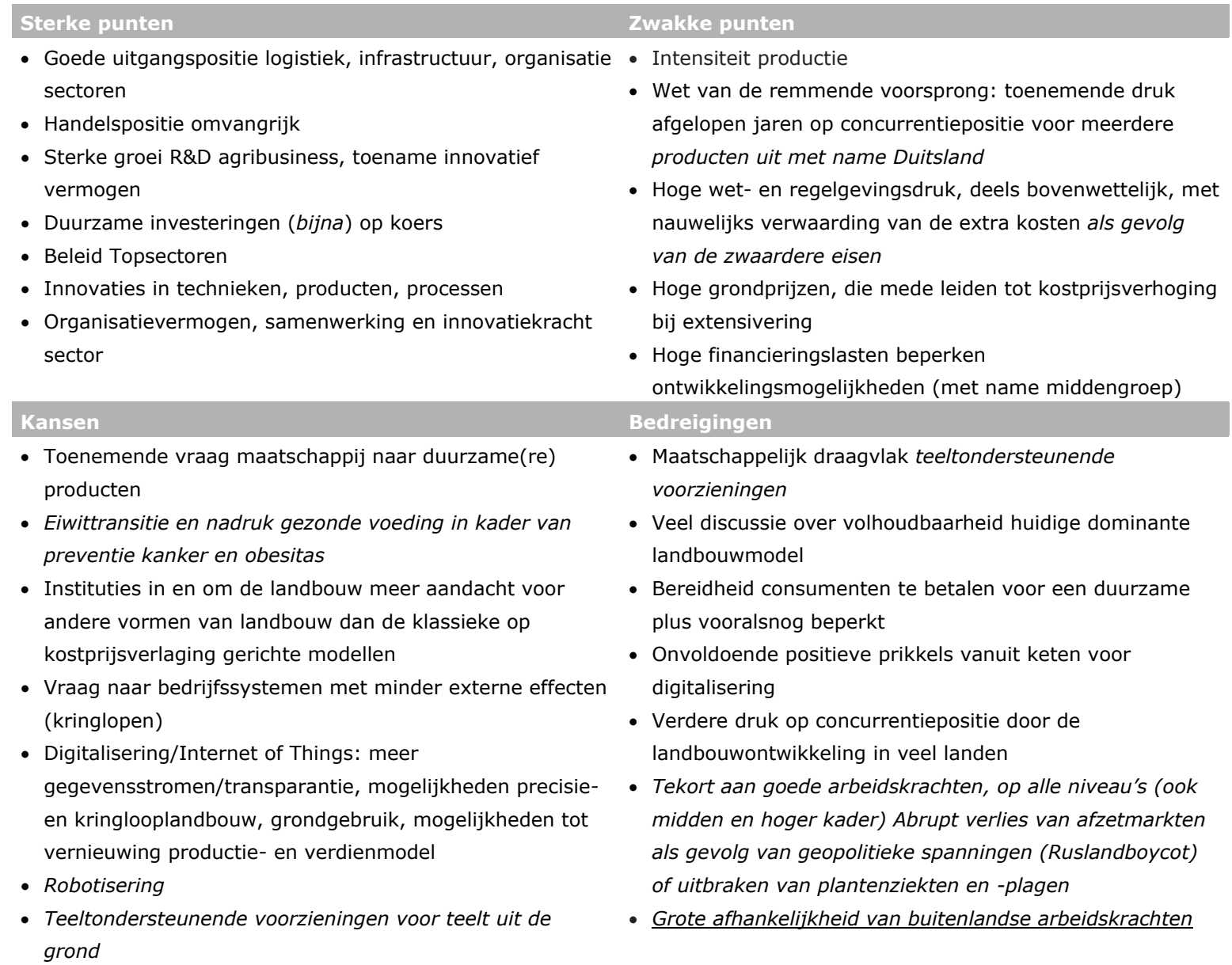

\section{Sterktes}

Innovatief vermogen (waaronder uitgaven aan $R \& D$ )

Geen gegevens over.

\section{Duurzame investeringen}

Het aandeel vollegrondsgroenten met het keurmerk 'On the way to Planetproof' was in 2020 laag met nog geen $2 \%$ van het areaal. Een sterke stijging van dit areaal is lastig omdat de meerwaarde voor de teler lang niet altijd opweegt tegen de meerkosten. Hoewel het areaal onder het label de afgelopen jaren is gegroeid tot 1.300 ha is er ook kritiek. Vooral op de administratieve lasten en de teelt- en afzetrisico's en het ontbreken van marktconforme vergoedingen.

Belangrijke gewassen in de vollegrondstuinbouw zijn asperge, bloemkool, broccoli, prei, sla en witte en rode kool. Als afnemer van vollegrondsgroenten heeft onder andere de firma HAK zich hard gemaakt om 'On the way to PlanetProof' in de vollegrondsgroenteteelt verder te ontwikkelen. De eerste rode kool en nu ook de spinazie wordt onder dit label aan hun geleverd. Dit jaar (2020) zijn er proeven met peulvruchten en zomergroenten. Telers ontvangen hiervoor een extra vergoeding van HAK is de belofte. Het gaat hier voornamelijk om akkerbouwmatig geteelde vollegrondsgroenten ten behoeve van de verwerking. Voor tuinbouwmatig geteelde vollegrondsgroenten is er geen bedrijf in de be- of verwerking dat zich opstelt zoals HAK.

In oktober 2020 was de analyse dat voor de vollegrondstuinbouwbedrijven door de coronacrisis naast mogelijke acute liquiditeitsproblemen vooral voor de wat langere termijn onzekerheden in de markt 
ontstaan. Hierdoor zullen bedrijven niet noodzakelijke investeringen uitstellen tot de gevolgen van de coronacrisis duidelijker zijn. Het totale investeringsniveau zal dalen maar als er geïnvesteerd kan worden zal dat gezien ontwikkelingen uit de markt veelal op een duurzame manier gebeuren. Totale investeringen zullen niet boven die van 2019 uit komen. Hiervoor zijn de onzekerheden te groot (van der Meulen et al., 2020).

Voorjaar 2021 - is de (expert)indruk dat de vollegrondstuinbouw over het algemeen weinig geleden heeft van de coronacrisis en dat een deel van de bedrijven er eerder van heeft geprofiteerd dan onder geleden. Het inkomen uit bedrijf bedroeg in 2020 naar schatting gemiddeld circa $€ 95.000$ per onbetaalde aje. Door hogere productprijzen bij een vergelijkbaar productieniveau komt het inkomen ruim boven het niveau van gemiddeld $€ 65.000$ in de vijf voorgaande jaren en is fors hoger dan het langjarige gemiddelde over de periode 2001-2019 (agrimatie.nl).

\section{Organisatie}

Een belangrijk deel van de telers is aangesloten bij telersverenigingen. ${ }^{23}$ Het overgrote deel van de groenten en fruit wordt door telersverenigingen en/of handelsbedrijven afgezet in de export (11,3 mrd. euro) en naar de Nederlandse detailhandel (5,5 mrd. euro) en een klein deel belandt rechtstreeks of via handelsbedrijven bij de foodservice en grootverbruikers in Nederland (1,1 mrd. euro).

Voor de vollegrondsgroenten geldt bovendien dat een deel van de producten aan de snijderijen wordt geleverd voor verwerking in gesneden groentepakketten en bijvoorbeeld zuurkool. Sommige grotere telers en telersverenigingen beschikken zelf over snijmachines en leveren rechtstreeks aan de detailhandel. In de vijfde schakel zijn de supermarktketens met een marktaandeel bij de groenten van bijna $90 \%$ verreweg het belangrijkste afzetkanaal naar de consument.

\section{Zwaktes}

Duitsland en het Verenigd Koninkrijk zijn de belangrijkste afzetmarkten voor Nederlandse tuinbouwmatige vollegrondsgroenten. De afgelopen decennia is Duitsland meer zelfvoorzienend geworden in tuinbouwmatige vollegrondsgroenten, wat de afzet naar Duitsland onder druk zet.

Het aandeel van de grondkosten in de kostprijs is relatief zeer klein, zeker ook in vergelijking met andere sectoren binnen de land- en tuinbouw. Dat ligt anders voor de arbeidskosten, die een fors deel uitmaken de kostprijs.

Op milieugebied zijn duidelijke stappen gezet, maar nog niet alle doelen zijn bereikt op het gebied van gewasbeschermingsmiddelen en emissies van nutriënten. De inzet van gewasbeschermingsmiddelen is sterk teruggelopen en het energiegebruik neemt niet toe. Door aanscherpingen binnen het mestbeleid is het stikstof- en fosfaatoverschot eveneens verkleind. Een aandachtspunt in dit verband is de hoge nitraatuitspoeling op percelen met bladgewassen op de zandgronden. Zie verder doelstelling $\mathrm{d}$ en e.

\section{Niet van toepassing:}

- grootschaligheid productie

- ongelijk speelveld; markt neemt producten af uit buitenland die onder andere - veelal lagere - eisen zijn geproduceerd

\section{Kansen}

Het imago van de vollegrondsgroenteteelt is goed. Er zijn de afgelopen jaren geen incidenten geweest met betrekking tot bijvoorbeeld volksgezondheid die dat imago hebben geschaad.

De (eiwit)transitie naar een meer plantaardig dieet is een positieve prikkel voor de vollegrondsgroente sector. Het zelfde geldt voor de grotere nadruk op het belang van gezonde voeding in het kader van preventie van kanker en obesitas.

\footnotetext{
${ }^{23}$ In de GMO groenten en fruit worden de onder de GMO erkende telersverenigingen aangeduid als producentenorganisaties. In de tekst hier worden telersverenigingen in algemene zin bedoeld.
} 
Natuurinclusieve landbouw zou ook in de vollegrondsgroenteteelt meegenomen kunnen worden, maar de indruk is dat het nog nauwelijks een rol speelt. Dit heeft zeker ook te maken met de hoge saldi, waardoor deelname al gauw relatief duur is.

Teeltsystemen uit de grond leveren ten opzichte van teelt in de grond betere prestaties op gebied van nutriëntenemissies, milieubelasting door gewasbeschermingsmiddelen en landgebruik. Daar staat tegenover dat de kostprijs stijgt, vooral door een toename in kosten van kapitaalgoederen. In teeltsystemen op substraat wordt deze kostenstijging in veel gewassen (deels) gecompenseerd door besparing op arbeid en/of een hogere opbrengstprijs. In watersystemen vormt rendabele teelt een grotere uitdaging. Dat komt mede omdat hier ook de energiekosten sterk toenemen als gevolg van het continu rondpompen van het water (Breukers et al., 2014).

Robotisering is een kans met name wat betreft het terugdringen van arbeidskosten. Robotisering is een optie in vele teelten en er wordt nu al mee geëxperimenteerd bij de oogst van asperges en aardbeien.

\section{Bedreigingen}

Een bijzonder aandachtspunt is de toename van teeltondersteunende voorzieningen in de opengrondstuinbouw, die worden gebruikt om de groeiomstandigheden van het gewas beter te kunnen beïnvloeden en controleren. Deze groei zal nog worden versterkt door de implementatie van teeltsystemen uit de grond. Door de teeltondersteunende voorzieningen kunnen teelten worden vervroegd en/of verlaat en beschermd tegen weersinvloeden, ziekten en plagen, waardoor beter kan worden voldaan aan de eisen van de afnemers. Ook kan het gebruik van teeltondersteunende voorzieningen leiden tot betere arbeidsomstandigheden of een lagere milieubelasting. De keerzijde van deze medaille is de mogelijke aantasting van maatschappelijk gewenste natuur- en landschapswaarden (Bremmer et al., 2019).

Wat betreft digitalisering constateert de Houtskool-SWOT onder meer dat het ontbreekt aan de prikkel bij de toeleveranciers en afnemers van boeren en tuinders om EDI (electronic data exchange) in te voeren en de papierstroom aan te vullen met EDI-stromen.

Vanuit de sector is in reactie hierop opgemerkt dat er in de keten wordt gewerkt aan zaken als hortifootprint en producentenpaspoort. Grote bedrijven in de agrosector dringen ook aan op digitalisering. In de versmarkt van vollegrondsgroenten is de indruk van Wageningen Economic Research dat dit minder aan de orde is.

De tuinbouwsector kampt met een tekort aan arbeidskrachten op alle niveaus, zowel lager als middenen hoger kader.

In een sector waarin wordt gewerkt met een vers product is er altijd kans op (grote) marktverstoringen door een plotselinge uitbraak van ziekten of gevaarlijke besmettingen voor de volksgezondheid of als grenzen sluiten om geopolitieke of fytosanitaire redenen. Mogelijkheden tot voorraadvorming zijn er niet, de afzet vergroten richting het verwerkingskanaal is slechts een beperkte optie.

Niet van toepassing

- import van goedkopere grondstoffen. 


\section{(c) Verbeteren van de positie van de landbouwers in de waardeketen;}

SWOT-samenvatting subdoelstelling C Verbeteren van de positie van de landbouwers in de waardeketen

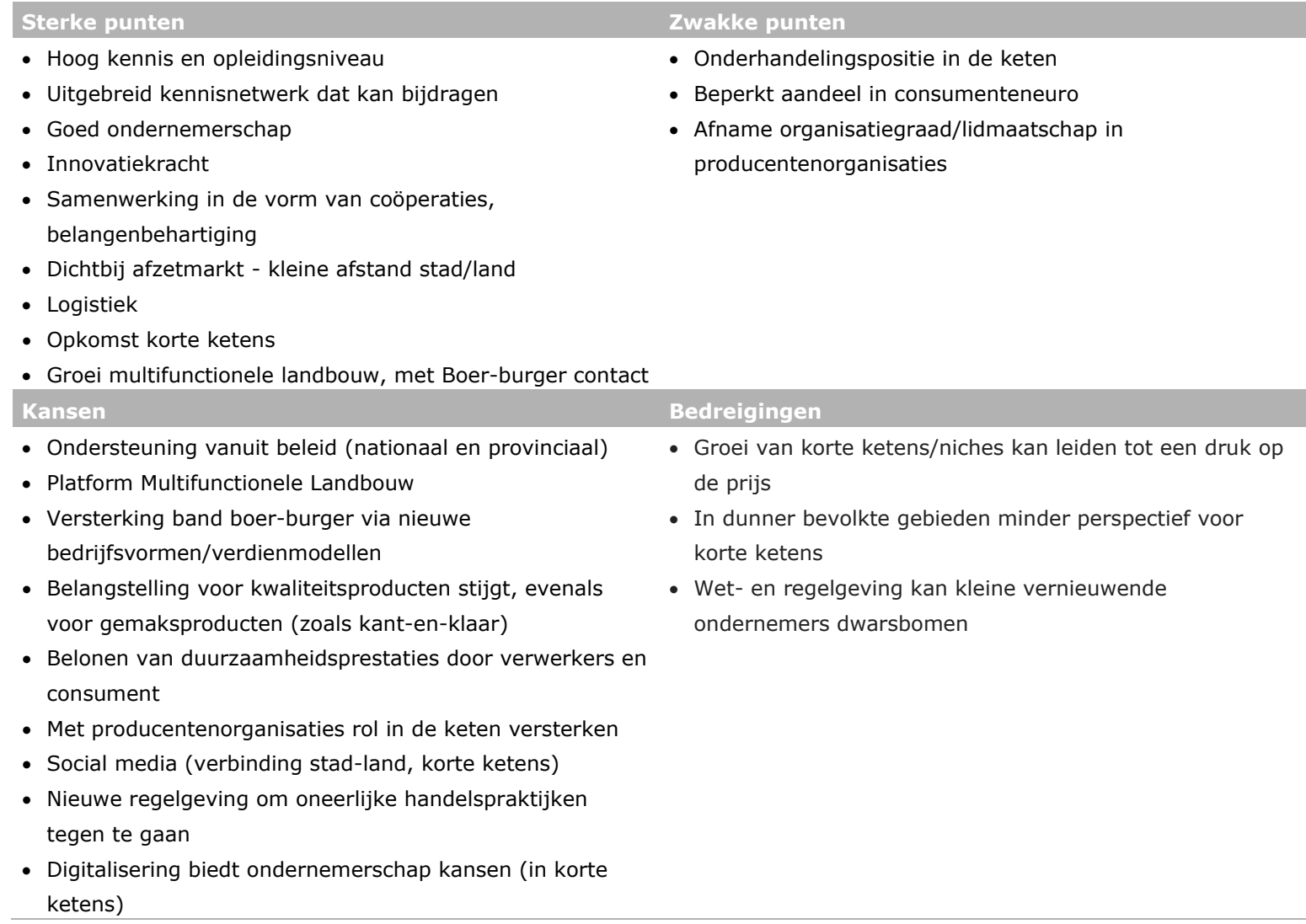

\section{Sterktes}

Geen aanvullingen.

\section{Zwaktes}

In de Nederlandse afzetketen van vollegrondsgroenten via het supermarktkanaal zijn feitelijk slechts zes inkoopcombinaties van supermarkten actief, te weten Ahold Delhaize (1.000 winkels), Superunie (1.500 winkels), Jumbo (720 winkels), Aldi (520 winkels), Lidl (400 winkels) en Van Tol Versunie (100 winkels). Hiervan maken in ieder geval Ahold en Jumbo gebruik van een vaste handelsrelatie voor groenten en fruit, via respectievelijk Bakker Barendrecht en The Greenery, die op hun beurt in Nederland samenwerken met een min of meer vaste groep van telers. Aan de andere kant van het spectrum opereert de discountformule Aldi, die de samenstelling van haar assortiment groenten en fruit voor een belangrijk deel laat afhangen van de bijdrage van een product aan de bedrijfswinst en wekelijks meerdere leveranciers tegen elkaar op laat bieden (Bremmer et al., 2019).

Ook de Duitse retail is van belang voor de afzet, deze is echter nooit goed in kaart gebracht.

De meeste vollegrondsgroente telers zijn redelijk trouw aan hun telersvereniging of handelsbedrijf, al is het vaak wel mogelijk om jaarlijks te switchen van afnemer. De rechtstreekse contacten van producenten met de detailhandel en consument zijn beperkt en laat men veelal aan de telersvereniging of groothandel over. Dit ligt wel enigszins anders voor de enkele zeer grote producenten die de sector rijk is. De coördinatie van de verwerking, verpakking, transport en promotie ligt ook bij de producentenvereniging of het groothandelsbedrijf.

In de periode 2010-2015 waren er in Nederland circa 15 producentenorganisaties met een GMO (gemeenschappelijke marktordening)erkenning, die circa 30\% van het areaal en de productiewaarde van de vollegrondsgroenteteelt vertegenwoordigden. Dit aantal en aandeel is de afgelopen jaren sterk afgenomen door aanscherping van de voorwaarden voor verkrijging van GMO-subsidie, opdat de effectiviteit van de subsidies wordt vergroot (EZ, 2016). De meeste overige telers zetten hun 
producten af via een van de ruim 1.200 handelsbedrijven in groente en fruit. Deze bedrijven zijn ook actief in de import van groente en fruit en kunnen zodoende hun afnemers jaarrond een breed assortiment groente en fruit aanbieden (Bremmer et al., 2019).

Recente cijfers over het aandeel van de productie dat wordt afgezet via erkende producentenorganisaties zijn nog in bewerking. De indruk is dat het aandeel verder is gedaald. In 2018 was minder dan de helft van de Nederlandse teelt aangesloten bij een door EU erkende PO, in 2013 was dit meer dan 90\% (informatie van GFH bij monde van Wim Rozenburg).

Niet van toepassing:

- import van andere kwaliteit.

\section{Kansen}

Naast een groeiende vraag naar kwaliteitsproducten, spelen gemak, gezondheid en genot ook een steeds grotere rol in het aankoopgedrag. Dit zijn zaken waar de sector ook goed op kan in spelen, met panklare producten bijvoorbeeld.

\section{Bedreigingen}

Geen aanvullingen.

Niet van toepassing:

- De bedreiging Handelsverdragen.

Het gaat grotendeels om dagverse producten, die bij voorkeur binnen 24-48 uur na de oogst in het winkelschap liggen in verband met kwaliteitsverlies en uitval. Concurrentie van buiten de EU is daarom minder aan de orde. 


\section{(d) Bijdragen tot matiging van en aanpassing aan klimaatverandering en tot duurzame energie;}

SWOT-samenvatting subdoelstelling D Bijdragen aan mitigatie en adaptatie aan klimaatverandering en leveren van een bijdrage aan een duurzame energieproductie

\begin{tabular}{ll} 
Sterke punten & Zwakke punten \\
- Kennis om te innoveren & \\
- Initiatieven van ketenpartijen & Bedreigingen \\
Kansen & - Business as usual in beleid en praktijk \\
- (Onderzoek naar) Nieuwe en innovatieve & - Toenemende concurrentie om de grond (ruimteclaims) \\
$\begin{array}{l}\text { bedrijfssystemen } \\
\text { - (Onderzoek naar) Energiebesparing op boerenbedrijven }\end{array}$ & $\begin{array}{l}\text { Doorgaande klimaatverandering met toenemend risico op } \\
\text { en in de keten (duurzaamheidsprogramma's) }\end{array}$ \\
$\begin{array}{l}\text { - Initiatieven van het bedrijfsleven } \\
\text { - Koploper worden in klimaatneutrale land- en tuinbouw }\end{array}$ & $\begin{array}{l}\text { - Verzilting van het grond- en oppervlaktewater } \\
\text { co } 2 \text { als grondstof is/wordt een beperking bij alternatieve } \\
\end{array}$ \\
\hline
\end{tabular}

Over de productie van hernieuwbare energie (C.41) zijn geen cijfers beschikbaar voor de vollegrondsgroenteteelt, hetzelfde geldt voor de emissie van broeikasgassen (indicator C.43).

Voor beide indicatoren geldt dat de bijdrage van de vollegrondsgroenteteelt beperkt zal zijn. Voor C.41 gaat het om het plaatsen van zonnepalen en windmolens. Hierover zijn geen gegevens beschikbaar. Volgens de sector zijn er wel initiatieven voor telen van groenten onder zonnepanelen en plaatsen van kleine windmolens. Data om dit te staven ontbreken vooralsnog.

Voor C.43 geldt dat de uitstoot vooral betrekking heeft op het energiegebruik. Dit is beperkt in de vollegrondsgroenteteelt tot het gebruik van machines en tot het bewaren van producten. Volgens Rvo (2012) bedroeg het totale energiegebruik in de vollegrondsgroenteteelt sector 0,7 PJ per jaar. Dat is gemiddeld $654 \mathrm{GJ}$ per bedrijf. Dieselbrandstof is voor het vollegrondsgroentebedrijf de belangrijkste energiebron, met name in de teeltuitvoering. Bedrijven die ook groenten bewaren of forceren hebben ook nog eens een grote elektriciteitsvraag (Rvo, 2012).

Volgens de Eindrapportage van het Convenant Schone en Zuinige Agrosectoren (2020), bedroeg het verbruik in de vollegrondgroenteteelt 0,6 PJ in 2018 (ter vergelijking, het verbruik in de glastuinbouw ligt rond de 100PJ). Het Convenant bevatte geen doelstelling voor het verminderen van het energiegebruik in de vollegrondsgroenteteelt. Het (directe) energieverbruik in de vollegrondsgroenteteelt is in de jaren 2016-2018 stabiel op 0,5 PJ (waarvan 0,3 PJ elektriciteit en 0,2 PJ motorbrandstoffen; dit cijfer wijkt af van het cijfer genoemd in het Convenant, onduidelijk is waarom). Ter vergelijking, in 2002 bedroeg het energieverbruik 0,4 PJ. De piek van het verbruik was in 2005 met $1,1 \mathrm{PJ} .{ }^{24}$ Sindsdien is het verbruik gedaald. Het indirecte energiegebruik dat nodig is voor onder andere het produceren van grondstoffen en het transporteren van producten is niet inbegrepen in deze cijfers.

In de akkerbouw en open teelten bestaat het energiegebruik voor ruim de helft uit motorbrandstoffen (onder andere grondbewerking, oogst, beregening). Het elektra- en gasverbruik dragen elk bijna voor $25 \%$ bij. Het elektra-verbruik (vooral voor drogen en bewaren van producten) is afgelopen 15 jaar behoorlijk stabiel. Het gasverbruik is na een stijging tot 2009 weer gedaald naar een niveau, vergelijkbaar met 2002 .

\section{Sterktes}

Geen aanvullingen.

Niet van toepassing:

- Veel mogelijkheden voor klimaatadaptatie en -mitigatie

${ }^{24}$ https://www.agrimatie. $n$ l/ThemaResultaat.aspx?subpubID $=22328$ themaID $=2273$ 
- Publiek-private samenwerking om klimaatopties toe te passen die in te passen zijn in de bedrijfsvoering

\section{Zwaktes}

Geen aanvullingen. Vanuit de sector is opgemerkt dat kleine bedrijven niet bij machte zijn grote investeringen te doen in de energietransitie vanwege de kapitaalintensiteit van bijvoorbeeld een windmolen.

Niet van toepassing: alle genoemde punten in de definitieve SWOT.

\section{Kansen}

Geen aanvullingen.

\section{Bedreigingen}

Doorgaande klimaatverandering kan een toenemend risico geven op opkomst/uitbraak van (nieuwe) ziekten en plagen, naast extreem weer als langdurige droogte of overvloedige regenval. Nu heeft niet alleen Nederland hiermee te maken, andere landen worden met dezelfde problemen geconfronteerd. De vraag is dan ook relevant of Nederland evenredig, harder of juist minder hard wordt getroffen door veranderingen in het klimaat. Ook de mate van veerkracht - van het kunnen omgaan met de veranderingen - is relevant. Gegeven de kennisinfrastructuur en de hoge organisatiegraad van ketens en sectoren, mag verwacht worden dat de sector goed in staat moet zijn om te gaan met de veranderingen. 


\section{(e) Bevorderen van duurzame ontwikkeling en efficiënt beheer van natuurlijke hulpbronnen zoals water, bodem en lucht;}

SWOT-samenvatting subdoelstelling E Bevorderen van duurzame ontwikkeling en efficiënt beheer van natuurlijke hulpbronnen, zoals water, bodem en lucht

\begin{tabular}{|c|c|}
\hline Sterke punten & Zwakke punten \\
\hline $\begin{array}{l}\text { - Efficiënte productie per eenheid product } \\
\text { - Verbruik gewasbeschermingsmiddelen is afgenomen } \\
\text { - Initiatieven in sector en keten om milieubelasting } \\
\text { productie terug te brengen } \\
\text { - Veel kennis in sectoren en ketens om de milieubelasting } \\
\text { van natuurlijke hulpbronnen te verminderen } \\
\text { - Samenwerking tussen diverse partijen in de keten om te } \\
\text { werken aan verduurzaming }\end{array}$ & $\begin{array}{l}\text { - Nog niet alle milieudoelstellingen zijn gehaald, vergt ook } \\
\text { - Toename milieubelasting gebruikte } \\
\text { gewasbeschermingsmiddelen } \\
\text { - Te veel focus op enkelvoudige doelstellingen } \\
\text { - Te weinig aandacht voor het systeem en de onderlinge } \\
\text { afhankelijkheden } \\
\text { - Grens aan wat technisch haalbaar is aan verminderen } \\
\text { algehele milieubelasting lijkt bereikt, gesloten systemen } \\
\text { - } \text { Ditgezonderd } \\
\text { regionale aanpak dan bij de huidige generieke aanpak } \\
\text { - Kosten verduurzaming niet altijd uit de markt te halen }\end{array}$ \\
\hline $\begin{array}{l}\text { - Ontwikkeling van nieuwe middelen, technieken en } \\
\text { landbouwsystemen, zoals teelt uit de grond } \\
\text { - Onderzoek en praktijk werken volop aan nieuwe } \\
\text { bedrijfssystemen en innovaties voor verduurzaming } \\
\text { - Langzaam groeiende vraag naar duurzamer } \\
\text { geproduceerde voedselproducten }\end{array}$ & $\begin{array}{l}\text { - Noodzaak tot aanpassing grondgebruik vanwege } \\
\text { klimaatverandering } \\
\text { - Verzilting en verslemping groeiend probleem } \\
\text { - Waterbeheer een grotere uitdaging als gevolg meer droge } \\
\text { jaren en meer piekbelasting } \\
\text { - Verharding maatschappelijke discussie landbouw } \\
\text { - Nog onvoldoende fytosanitaire kennis producenten/fyto- } \\
\text { bewustzijn }\end{array}$ \\
\hline
\end{tabular}

Voor de SWOT-analyse van subdoelstelling (e) zijn de contextindicatoren C.37 watergebruik in de landbouw, C.38 waterkwaliteit, C.39 organisch stofgehalte bouwland, C.40 bodemerosie als gevolg van water en C.48 risico en effect van gewasbeschermingsmiddelen relevant. Op basis van nationale data - op basis van Eurostat zijn geen gegevens voorhanden - is het beeld voor de vollegrondsgroenteteelt als volgt.

\section{Gewasbescherming}

De kosten van het gewasbeschermingsbeleid zijn sinds 2010 voor de meeste geselecteerde voorbeeldgewassen gelijk gebleven of licht gestegen. Het meest stegen de kosten bij de teelt van spruitkool (19\%) en aardbei (2\%). De oorzaak is dat in deze teelten middelen vervallen zijn en minder effectieve alternatieven beschikbaar zijn gekomen. Voor spruitkool geldt bovendien dat de toegestane dosering van een aantal middelen is verlaagd, waardoor trips, witte vlieg, luizen en koolvlieg moeilijker zijn te bestrijden (PBL, 2019).

Vergeleken met omliggende landen zijn de kosten voor de teler om te voldoen aan het gewasbeschermingsbeleid in Nederland iets hoger. Een oorzaak is dat in het omliggende buitenland iets meer middelen zijn toegelaten (1.020 in Nederland versus 1.114 gemiddeld in de centrale zone). Dit wordt voornamelijk veroorzaakt door verschillen in de toelating, maar ook doordat producenten van gewasbeschermingsmiddelen niet altijd een aanvraag doen voor een toelating in Nederland. Hierdoor kunnen gewasbeschermingsproblemen in het buitenland iets effectiever worden aangepakt (PBL, 2019).

In 2014 is er een Green Deal Groene Gewasbeschermingsmiddelen gesloten (Ctgb, 2020). Groene gewasbeschermingsmiddelen zijn middelen van natuurlijke oorsprong met een ingeschat laag risico voor mens, dier, milieu en niet-doelwit organismen; zoals:

- planten, dieren, micro-organismen;

- bepaalde mineralen;

- nagemaakte middelen die identiek zijn aan de natuurlijke stof. 
In Nederland waren begin 2020 zeventien laagrisicomiddelen en veertig middelen op basis van microorganismen toegelaten (Ctgb). Dit aantal is nog te weinig om de afgenomen beschikbaarheid van chemische middelen op te vangen. Als gevolg van de herbeoordeling op EU-niveau van actieve stoffen die worden gebruikt voor gewasbeschermingsmiddelen, is het aantal actieve stoffen gedaald van meer dan 1.000 naar circa 500. Daarvan bestaat ongeveer $25 \%$ uit micro-organismen, feromonen en plantenextracten, die als laag-risico stoffen worden beoordeeld (Nefyto, 2018).

Uit de meest recente nalevingsmetingen van de Nederlandse Voedsel-en Warenautoriteit (NVWA) blijkt dat het nalevingsniveau in de fruitteelt, sierteelt onder glas, akkerbouw, vollegrondsgroenteteelt en de bloembollenteelt varieert van 80 tot $90 \%$. Het gaat dan om bedrijven die bij een nalevingsonderzoek (controle) geen bestuursrechtelijke maatregel (boeterapport) of strafrechtelijk vervolgtraject krijgen opgelegd (PBL, 2019).

De emissies zijn afgenomen, maar de berekende milieubelasting is toegenomen In de vollegrondsgroenteelt is het verbruik van gewasbeschermingsmiddelen met 31 procent gedaald tussen 2012 en 2016 (van 307.000 kg naar 212.000 kg). Naast het gebruik in absolute hoeveelheden, is de milieubelasting van de gebruikte middelen per $\mathrm{kg}$ actieve stof een belangrijke graadmeter. De milieubelasting is met $34 \%$ gestegen, deze belasting wordt uitgedrukt in milieu-indicatorpunten (MIP), een maat voor het aantal normoverschrijdingen uitgedrukt in toxische eenheden. De emissies naar het oppervlaktewater zijn gedaald. Aangezien drainage de belangrijkste emissieroute is, wordt dit waarschijnlijk veroorzaakt door een verschuiving naar middelen die minder sterk uitspoelen. De milieubelasting door de open teelten wordt gedomineerd door drie stoffen, namelijk de insecticiden deltamethrin, lambda-cyhalothrin en esfenvaleraat. Samen zijn ze goed voor circa $90 \%$ van de berekende belasting van het oppervlaktewater ( $\mathrm{PBL}, 2019)$. Het middel deltametrin is inmiddels niet meer toegelaten, met uitzondering van een aantal specifieke toepassingen binnenshuis (Ctgb, 2019).

\section{Sterktes}

Op milieugebied zijn duidelijke stappen gezet. De inzet van gewasbeschermingsmiddelen is sterk teruggelopen en het energiegebruik neemt niet toe (zie analyse bij doelstelling d). Door aanscherpingen binnen het mestbeleid is het stikstof- en fosfaatoverschot eveneens verkleind (Bremmer et al., 2019).

Niet van toepassing:

- Milieudruk grond en oppervlaktewater met stikstof en fosfaat is stabiel tot afgenomen.

\section{Zwaktes}

De milieubelasting van het gebruik van gewasbeschermingsmiddelen in de teelt is toegenomen (PBL, 2019).

Een blijvend aandachtspunt is de hoge nitraatuitspoeling op percelen met bladgewassen op de zandgronden (Bremmer et al., 2019). Dat is echter grotendeels inherent aan het productiesysteem.

\section{Kansen}

Verdere verduurzaming van de teelt door het (nog) verder terugdringen van de emissies van gewasbeschermingsmiddelen, fosfaat en stikstof en het verminderen van het energiegebruik. Teelt uit de grond is een van de mogelijkheden daartoe, alhoewel deze niet op alle punten even goed scoort.

Op basis van een onderzoek uit 2014 (Breukers et al.) is de conclusie dat ten opzichte van teelt in de grond, de teeltsystemen uit de grond betere prestaties leveren op het gebied van nutriëntenemissies, milieubelasting door gewasbeschermingsmiddelen, en landgebruik. Daar staat tegenover dat de kostprijs stijgt, vooral door een toename in kosten van kapitaalgoederen. In teeltsystemen op substraat wordt deze kostenstijging in veel gewassen (deels) gecompenseerd door besparing op arbeid en/of een hogere opbrengstprijs. In watersystemen vormt rendabele teelt een grotere uitdaging. Dat komt mede omdat hier ook de energiekosten sterk toenemen als gevolg van het continu rondpompen van het water. 
Terugdringen van het energieverbruik en broeikasgasemissies vormt dan ook een belangrijk verbeterpunt voor de teelt op water. Dat kan bijvoorbeeld door een efficiëntere recirculatie en door gebruik van duurzamere productiemiddelen. Beide verbeteringen hebben ook een gunstig effect op de kostprijs. Bij de teelt op substraat liggen er onder meer verbetermogelijkheden op het gebied van watergebruik. Mogelijk biedt recirculatie ook bij deze systemen een uitkomst (Breukers et al., 2014).

Al deze teeltsystemen zijn nog volop in ontwikkeling. Het programma Teelt de Grond uit ontwikkelt rendabele teeltsystemen voor de vollegrondstuinbouw in de sectoren groenten, bloembollen, boomteelt, fruit en zomerbloemen die voldoen aan de Europese regelgeving voor de waterkwaliteit. Uitgangspunt is dat de systemen zowel een sterke emissiebeperking hebben als voordelen voor ondernemers opleveren en gewaardeerd worden door de maatschappij. Voordelen voor ondernemers zijn bijvoorbeeld een grotere arbeidsefficiëntie, betere kwaliteit of nieuwe marktkansen. Onderzoekers van Wageningen UR en Proeftuin Zwaagdijk werken in het programma nauw samen met telers, brancheorganisaties en adviseurs uit de sectoren. De overheid financiert het programma via de Topsector Tuinbouw \& Uitgangsmaterialen. ${ }^{25}$

Een belangrijk nadeel van teeltondersteunende maatregelen en teeltsystemen uit de grond is dat deze de natuurlijke habitats en landschapswaarde verslechteren (zie doelstelling $\mathrm{f}$ ).

Niet van toepassing:

- Visie Kringlooplandbouw biedt een wenkend perspectief voor systeemverandering en kan als katalysator werken.

Gezien de Europese afzetmarkt van de vollegrondsgroentesector is dit alleen haalbaar als de kringloop wordt gesloten op West-Europese schaal.

\section{Bedreigingen}

Vanuit de sector is de aanvulling gegeven dat er onvoldoende fytosanitaire kennis en bewustzijn is bij telers.

Niet van toepassing:

- Grote gevolgen van de rechterlijke uitspraak inzake het Programma Aanpak Stikstof en de aanvullende wetgeving.

Niet relevant voor de vollegrondsgroenteteelt.

${ }^{25}$ https://www.teeltdegronduit. nl/nl/teeltdegronduit. htm 
(f) Bijdragen tot de bescherming van de biodiversiteit, versterken van ecosysteemdiensten en in stand houden van habitats en landschappen.

SWOT-samenvatting subdoelstelling F Bijdragen aan de bescherming van de biodiversiteit, het versterken van ecosysteemdiensten en in stand houden van leefgebieden en landschappen

\begin{tabular}{|c|c|}
\hline Sterk & Zwakke punten \\
\hline $\begin{array}{l}\text { - De diversiteit van het Nederlandse landschap door de } \\
\text { ligging in een vruchtbare delta, de variatie in } \\
\text { grondsoorten en de ontginningsgeschiedenis } \\
\text { - Stelsel voor collectief agrarisch natuur- en } \\
\text { landschapsbeheer, waarmee gebiedsgericht aan de slag } \\
\text { wordt gegaan voor biodiversiteit } \\
\text { - Groeiende bereidheid bij boeren om zich in te zetten voor } \\
\text { natuur, ecosysteemdiensten en biodiversiteit } \\
\text { Ontwikkelingen in de keten om biodiversiteit in de } \\
\text { landbouw te belonen }\end{array}$ & $\begin{array}{l}\text { - De zeer zorgelijke toestand van biodiversiteit, } \\
\text { ecosysteemdiensten en landschappen in het landelijk } \\
\text { gebied en het vooralsnog ontbreken van een positieve } \\
\text { trend } \\
\text { - Biodiversiteit maakt vrijwel geen deel uit van de } \\
\text { agrarische bedrijfsvoering, inspanningen voor de } \\
\text { versterking van biodiversiteit worden veelal onvoldoende } \\
\text { beloond } \\
\text { - Het betalen voor biodiversiteit door de markt en de } \\
\text { consument is nog geen gemeengoed } \\
\text { - Landbouwgrond in Nederland is duur, maatregelen voor } \\
\text { biodiversiteit zijn op bedrijfsniveau alleen aantrekkelijk } \\
\text { als er voldoende beloning tegenover staat } \\
\text { - Teeltondersteunende maatregelen en teeltsystemen uit de } \\
\text { grond verslechteren de natuurlijke habitats en } \\
\text { landschapswaarde }\end{array}$ \\
\hline Kansen & \\
\hline $\begin{array}{l}\text { - Groeiende maatschappelijke en politieke aandacht voor } \\
\text { belang biodiversiteit (zoals onder andere tot uiting komt } \\
\text { in het Deltaplan Biodiversiteitsherstel) } \\
\text { - Toenemende belangstelling bij boeren voor } \\
\text { natuurinclusieve landbouw } \\
\text { - Streven van de overheid om zones van extensieve } \\
\text { landbouw rondom Natura 2000-gebieden te ontwikkelen } \\
\text { - Ontwikkeling van vergoedingen voor ecosysteemdiensten, } \\
\text { in verschillende vormen van publiek-private } \\
\text { samenwerking } \\
\text { Innovatievermogen door combinatie van kennis en } \\
\text { expertise in de agrifoodsector, met kennis van ecologie en } \\
\text { biodiversiteit }\end{array}$ & $\begin{array}{l}\text { - Intensivering agrarisch landgebruik (resulterend in } \\
\text { vermesting, verdroging, verzuring, versnippering) } \\
\text { - Industrialisering, verstedelijking en toename } \\
\text { infrastructuur } \\
\text { - Klimaatverandering } \\
\text { - Energietransitie met aanleg van zonne-akkers en } \\
\text { zonneweiden, evenals biomassagewassen } \\
\text { - Geen consistente registratie van landschapselementen. } \\
\text { Alleen de landschapselementen waar subsidie voor } \\
\text { ontvangen wordt zijn geregistreerd in het perceelsregister } \\
\text { Rvo } \\
\text { - Afname van insecten leidt tot minder natuurlijke } \\
\text { bestuivers voor de landbouw } \\
\text { Ontbreken van integraal beleid voor bodem, mest, } \\
\text { klimaat, biodiversiteit en landschap }\end{array}$ \\
\hline
\end{tabular}

$\mathrm{Er}$ is geen goed kwantitatief beeld van deelname door vollegrondsgroentebedrijven aan maatregelen om de biodiversiteit te versterken, zoals agrarisch natuurbeheer. Gegeven de hoge saldi van groentes, is de inschatting dat deelname niet groot is omdat vergoedingen gebaseerd zijn op gemiddeldes. Deze zijn ontoereikend voor de vollegrondsgroentebedrijven.

Als bedrijven met groentes kleiner dan 15 ha nu GLB-steun aanvragen, vallen ze in de uitzonderingen wat betreft vergroening. Als de eisen aan de basistoeslag veranderen als gevolg van de voorgenomen herziening van het GLB (de zogenaamde verhoogde conditionaliteit), verandert deze uitzonderingspositie mogelijk. Denkbaar is dat bedrijven dan geheel afhaken in het aanvragen van steun, en daarmee ook niet onder de verhoogde conditionaliteitseisen vallen, omdat voor deze bedrijven de kosten van het voldoen aan de verhoogde conditionaliteit niet opwegen tegen de baten van de toeslag.

Functionale agrobiodiversiteit, het versterken van het natuurlijke vermogen om ziekten en plagen te beheersen in cultuurgewassen door de biodiversiteit te stimuleren, kan wel een rol (gaan) spelen in de vollegrondsgroenteteelt, en dan met name bij de preventie van schadelijke insecten. Dit is van belang omdat juist de insecticiden onder druk liggen vanwege de kwalijke milieueffecten. Recent onderzoek is niet beschikbaar naar functionele agrobiodiversiteit. De expertindruk is dat er nog weinig gebeurt op dit gebied, uitgezonderd kleinschalige biologische bedrijven die hier wel veel aandacht voor hebben. 
Wel is er veel (lopend) onderzoek naar het vergroten van de weerbaarheid van huidige productiesystemen, bijvoorbeeld met behulp van minimale grondbewerking en organische-stofbeheer, groenbemesters, mengteelten, strokenteelten, agroforestry, slimme landbouwtechnologie, mechanisatie en robotica én systemen die zich richten op minimale afhankelijkheid van gewasbeschermingsmiddelen (Proeftuin Agroecologie en Technologie, 2021). De gemeenschappelijke deler van deze projecten is het stimuleren van biodiversiteit met als doel het gebruik van gewasbeschermingsmiddelen tot een minimum te beperken en de uitspoeling van nutriënten substantieel te verminderen.

\section{Sterktes}

Geen aanvullingen.

\section{Zwaktes}

Teeltondersteunende maatregelen en teeltsystemen uit de grond verslechteren de natuurlijke habitats en landschapswaarde.

\section{Kansen}

Geen aanvullingen.

\section{Bedreigingen}

Geen aanvullingen. 


\subsection{Referenties}

Agentschap NL (2012). Duurzame energie, dat loont voor u als groenteteler. Belangrijkste duurzame energietoepassingen in de vollegrondsgroenteteelt. Via:

https://www.rvo.nl/sites/default/files/bijlagen/Duurzame\%20energie\%20dat\%20loont\%20voor\% 20u\%20als\%20groenteteler_1.pdf

Berkhout, Petra, Jakob Jager en Bert Smit (2019). Inkomenseffecten van de GLB-aanpassingen per 2020; Een quick scan. Wageningen, Wageningen Economic Research, Rapport 2019-114

Bremmer, Johan, Bas Janssens, Marc Ruijs, Jan Benninga, Robert Stokkers, Gerben Splinter, Pepijn Smit, Linda Puister-Jansen (2019). Plantaardige ketens in beeld.

https://doi.org/10.18174/494597

Breukers, Annemarie, Rob Stokkers, Joanneke Spruijt, Peter Roelofs, Janjo de Haan (2014). Teelt de grond uit in perspectief. Prestaties van teeltsystemen op het gebied van integrale duurzaamheid. PPO publicatie nr. 578, Wageningen UR

Ctgb (College voor de Toelating van Gewasbeschermingsmiddelen) (2019) https://www.ctgb.nl/actueel/nieuws/2019/11/28/bekendmakingen-collegebesluiten-biociden-d.d.-27-november-2019

Ctgb (2020) https://www.ctgb.nl/onderwerpen/green-deal-groene-gewasbeschermingsmiddelen

EZ (ministerie van Economische Zaken) (2019). Nationale Strategie voor toepassing van de Gemeenschappelijke Marktordening voor groenten en fruit in Nederland. Periode 2017-2020. Den Haag

Meulen, H.A.B. van der, J.H. Wisman, J.H. Jager, G.D. Jukema en R.W. van der Meer (2020). Investeringsniveau duurzame productiemiddelen; Duurzaamheidsindicator (DP01) in de Rijksbegroting 2021. Wageningen, Wageningen Economic Research, Rapport 2020-103

Nefyto (2018). https://nefyto.foleon.com/nefyto-bulletins-2018/nefdigibul20182/2-europa/

PBL (Planbureau voor de Leefomgeving) (2019). Geïntegreerde gewasbescherming nader beschouwd. Tussenevaluatie van de nota Gezonde groei, duurzame oogst. PBL-publicatienummer: 3549

Proeftuin Agroecologie en Technologie (2012) https://www.wur.nl/nl/OnderzoekResultaten/Onderzoeksinstituten/plant-research/Open-teelten/Landbouw-van-detoekomst/proeftuin-agroecologie.htm

Rvo (Rijksdienst voor Ondernemend Nederland) (2020). Convenant Schone en Zuinige Agrosectoren 2008-2020. Eindrapportage. Via:

https://www.rijksoverheid.nl/documenten/kamerstukken/2020/12/18/eindrapportage-convenantschone-en-zuinige-agrosectoren-2008---2020

Tacken, Gemma, Joris Galama, Patricia Jaspers, Victor Immink, Lusine Aramyan (2021). Korteketenproducten in Nederland; Zijn horeca, catering en supermarkten geïnteresseerd in producten uit de regio. Wageningen, Wageningen Economic Research, Rapport 2021-013 


\subsection{Bijlage Indicatoren}

N.B. Alle data zijn op basis van Eurostat of nationale data als in Eurostaat geen gegevens beschikbaar waren op deelsectorniveau.

Indicatoren C.12 tot en met C.34

Tabel C.12 Aantal bedrijven naar bedrijfsgrootte in ha en standaardopbrengst (SO)

\begin{tabular}{|c|c|c|c|}
\hline & \multicolumn{3}{|c|}{ Vollegrondsgroentebedrijven } \\
\hline & 2010 & 2015 & 2020 \\
\hline \multicolumn{4}{|c|}{ Aantal bedrijven naar omvang in ha } \\
\hline$<1$ ha & 76 & 71 & 66 \\
\hline $1-5$ ha & 223 & 168 & 153 \\
\hline 5-10 ha & 209 & 173 & 160 \\
\hline $10-30$ ha & 319 & 336 & 268 \\
\hline $30-50$ ha & 116 & 105 & 116 \\
\hline$>50$ ha & 87 & 108 & 90 \\
\hline Total & 1.030 & 961 & 853 \\
\hline \multicolumn{4}{|c|}{ Aantal bedrijven naar omvang in standaardopbrengst (SO) } \\
\hline SO: $3.000-25.000$ euro & 131 & 101 & 79 \\
\hline SO: $25.000-100.000$ euro & 309 & 255 & 220 \\
\hline SO: $100.000-250.000$ euro & 255 & 242 & 216 \\
\hline SO: $250.000-500.000$ euro & 180 & 158 & 136 \\
\hline SO: $500.000-1.000 .000$ euro & 93 & 115 & 116 \\
\hline SO: $1.000 .000-1.500 .000$ euro & 38 & 37 & 42 \\
\hline SO: $1.500 .000-3.000 .000$ euro & 20 & 39 & 32 \\
\hline SO: $>3.000 .000$ euro & 4 & 14 & 12 \\
\hline Totaal & 899 & 860 & 774 \\
\hline \multicolumn{4}{|c|}{ Gemiddelde bedrijfsgrootte in ha en so } \\
\hline ha & 20,2 & 23,5 & 23,8 \\
\hline SO (x 1.000 euro) & 285 & 426 & 437 \\
\hline \multicolumn{4}{|l|}{ idem $2010=100$} \\
\hline ha & 100 & 116 & 118 \\
\hline SO (x 1.000 euro) & 100 & 150 & 154 \\
\hline
\end{tabular}

Tabel C.13a Arbeidsinzet - in arbeidsjaareenheden

\begin{tabular}{|c|c|c|c|}
\hline Vollegrondsgroentebedrijven & 2010 & 2015 & 2020 \\
\hline Arbeidsjaareenheden (regelmatig en onregelmatig) regulier werkzaam & 3.039 & 2.648 & 2.484 \\
\hline man & 2.081 & 1.045 & 1.110 \\
\hline Niet-reguliere arbeid & 1.561 & 1.930 & 1.583 \\
\hline
\end{tabular}

Tabel C.13b Arbeidsinzet: aantal arbeidsjaareenheden naar gezinsarbeid en vreemde arbeid

\begin{tabular}{lrrr} 
Vollegrondsgroentebedrijven & 2010 & 2015 & 2020 \\
gezin & 1.669 & 1.530 & 1.301 \\
\hline Niet-gezin & 2.931 & 3.048 & 2.766 \\
\hline
\end{tabular}


Tabel C.14 Leeftijdsopbouw agrarische bedrijfshoofden

\begin{tabular}{lrrr} 
Vollegrondsgroentebedrijven & 2010 & 2015 & 90 \\
$<40$ jaar (A) & 126 & 2020 \\
\hline$>55$ jaar (B) & 338 & 375 & 431 \\
\hline Totaal & 1.030 & 361 & 24 \\
\hline ratio (A/B) & 37 & 18 \\
\hline
\end{tabular}

Tabel C.16 Aantal bedrijven met een opvolger

\begin{tabular}{lrr} 
Vollegrondsgroentebedrijven & 2012 & 2016 \\
aantal bedrijven met een opvolger & 125 & 2020 \\
\hline aantal bedrijven met een bedrijfshoofd $>51$ jaar & 513 & 135 \\
\hline aantal bedrijven met een bedrijfshoofd $<51$ jaar & 403 & 467 \\
\hline aandeel bedrijven met een opvolger & 24 & 279 \\
\hline
\end{tabular}

Tabel C.17 Areaal vollegrondsgroenten (ha) op gespecialiseerde vollegrondsgroentebedrijven

\begin{tabular}{lrr} 
& 2010 & 2015 \\
Vollegrondsgroentenbedrijven & 13.904 & 2020 \\
\hline
\end{tabular}

C18-C23: niet beschikbaar

Tabel C.24 Netto toegevoegde waarde per aje (in euro)

\begin{tabular}{lrrr} 
& 2010 & 2015 & 2019 \\
Vollegrondsgroentebedrijven (in euro) & $\mathbf{3 0 . 1 0 5}$ & $\mathbf{4 1 . 1 0 3}$ & $\mathbf{4 0 . 7 5 4}$ \\
\hline Index & 100 & 137 & 135 \\
\hline
\end{tabular}

Tabel C.25 Inkomen uit bedrijf per oaje (in euro)

\begin{tabular}{lrrr} 
& 2010 & 2015 & 2019 \\
Vollegrondsgroentebedrijven (in euro) & 22.032 & 69.568 & 54.512 \\
\hline Index & 100 & 316 & 247 \\
\hline
\end{tabular}

C. 26 niet beschikbaar.

C.27 niet beschikbaar.

C. 28 niet beschikbaar.

C.29 niet beschikbaar.

C.30 Handel.

Op het niveau van vollegrondsgroente zijn niet direct gegevens beschikbaar via Eurostat of CBS. De beschikbare handelsdata geven de in- en uitvoercijfers weer voor groenten totaal, de in- en uitvoer van glasgroenten is daarbij inbegrepen. Op basis van onderzoek uit 2017 (Bremmer et al., 2017) is duidelijk dat de export van vollegrondsgroenten in 2017 ruim $€ 11$ miljard bedroeg. Via GFH zijn aanvullende gegevens verkregen en meegenomen in de beschrijving van de sector.

C.31 niet beschikbaar. 
Tabel C.32 Areaal biologische landbouw en aandeel areaal biologische landbouw op totale areaal vollegrondsgroente

\begin{tabular}{|c|c|c|c|c|c|c|}
\hline Aantal hectares & 2015 & 2016 & 2017 & 2018 & 2019 & 2020 \\
\hline Totaal areaal biologisch plus in omschakeling & 1.579 & 873 & 1.309 & 1.250 & 1.209 & 1.390 \\
\hline Areaal biologisch & 1.521 & 811 & 1.165 & 1.034 & 1.049 & 1.251 \\
\hline Totaal areaal & 22.944 & 20.753 & 21.833 & 20.945 & 21.274 & 20.613 \\
\hline \multicolumn{7}{|l|}{ Aandeel (\%) } \\
\hline Areaal biologisch & 6,6 & 3,9 & 5,3 & 4,9 & 4,9 & 6,1 \\
\hline Areaal in omschakeling & 0,3 & 0,3 & 0,7 & 1,0 & 0,7 & 0,7 \\
\hline Totaal areaal & 100 & 100 & 100 & 100 & 100 & 100 \\
\hline
\end{tabular}

Tabel C.33 Intensieve landbouw, aandeel areaal met hoge input ( $>350$ euro aan input van kunstmest, voer en pesticiden /ha)

\begin{tabular}{lrrr} 
Aandeel & 2010 & 2015 & 2019 \\
Vollegrondsgroentebedrijven & 75 & 95 & 89 \\
\hline
\end{tabular}

C.34 niet beschikbaar.

\section{Indicatoren C.35-C.48}

C.35 niet beschikbaar naar type bedrijf

C. 36 niet beschikbaar naar type bedrijf

C.38 niet beschikbaar naar type bedrijf

C. 40 niet beschikbaar naar type bedrijf

C.41 niet beschikbaar naar type bedrijf

C.42 niet beschikbaar naar type bedrijf

C.43 niet beschikbaar naar type bedrijf

C.44 niet beschikbaar naar type bedrijf

C. 45 niet beschikbaar naar type bedrijf

C.46 niet relevant voor de vollegrondsgroenteteelt

C.47 niet relevant voor de vollegrondsgroenteteelt

Tabel C.48 Afzet pesticiden (in 1.000 ton werkzame stof)

\begin{tabular}{l|lr} 
& 2010 & 2015 \\
\hline Afzet pesticiden (1.000 ton werkzame stof) & & 2019 \\
\hline Vollegrondsgroentebedrijven & $\mathbf{0 , 3 1}$ & $\mathbf{0 , 1 6}$ \\
\hline
\end{tabular}




\section{SWOT-analyse deelsector snijbloementeelt}

Jan Benninga en Marc Ruijs

N.B. deze analyse moet worden gelezen in samenhang met de SWOT-analyse op het niveau van de landbouw als geheel. Onderhavige analyse verbijzondert de SWOT-analyse waar nodig naar de deelsector in kwestie.

\subsection{Algemene beschrijving van de sector snijbloemen}

Korte beschrijving van de sector ${ }^{26}$

De snijbloementeelt in Nederland heeft een lange traditie. Er is een belangrijk verschil tussen onder glas geteelde bloemen en buiten geteelde bloemen. Deze notitie focust zich op onder glas geteelde bloemen, waar ook het grootste productieareaal is te vinden (zie tabel C.17, Bijlage 1).

Belangrijke snijbloemen qua zijn chrysant, roos en lelie. Ook tulp is een belangrijke snijbloem. De productie van lelies, ook afkomstig van bollen, valt wel onder de snijbloementeelt. Deze teelt vindt jaarrond op gespecialiseerde bedrijven plaats.

De snijbloementeelt in Nederland heeft vanaf de jaren vijftig een enorme ontwikkeling doorgemaakt, gekenmerkt door vele technische ontwikkelingen. Het meest in het oog springend zijn de klimaatbeheersing, het telen los van de ondergrond, de toepassing van bosmachines en de toepassing van assimilatiebelichting. Op het gebied van gewasbescherming is er innovatie in nieuwe spuittechnieken geweest en toepassing van biologische bestrijding.

\section{Productiesysteem}

In Nederland worden snijbloemen doorgaans op substraat geteeld. In de meeste gevallen gebeurt dit op steenwolmatten, maar andere substraten zoals kokos en lava komen ook voor. De chrysant wordt nog steeds in de grond geteeld. De teelt op water is voor enkele gewassen geprobeerd maar zonder succes. Hetzelfde geldt voor mobiele teeltsystemen. Het idee erachter was verbetering van de ruimtebenutting en arbeidsproductiviteit. Deze voordelen bleken echter niet op te wegen tegen de kosten verbonden met de investering. De teeltwijze per soort kan variëren. Van een chrysant wordt voor iedere bloem een stekje geproduceerd. Van een gewas zoals gerbera wordt gedurende het hele teeltseizoen geoogst. Een rozenstruik wordt voor meerdere jaren opgezet.

Ondanks dat het belangrijkste deel van het snijbloemenareaal los van de grond wordt geteeld en water wordt gerecirculeerd is het tot op heden niet gelukt volledig gesloten te telen. Het kan soms nog voorkomen dat drainwater wordt geloosd op het oppervlaktewater. Wel beschikken steeds meer bedrijven over omgekeerde-osmoseapparatuur, waarmee zouten uit het grondwater kunnen worden gefilterd. In de Kaderrichtlijn water 2000/60/EG en de 2e nota duurzame gewasbescherming zijn de richtlijnen bepaald voor het lozen van drainwater op oppervlaktewater. In het Activiteitenbesluit milieubeheer staat omschreven dat de glastuinbouw wordt verplicht tot het zuiveren van water dat wordt geloosd van overblijfselen van gewasbeschermingsmiddelen (Rijksoverheid, Helpdesk Water).

\section{Aandeel biologisch}

Minder dan 1\% van de snijbloemenbedrijven teelt op biologische wijze, het areaal lag in 2015 op 9 ha, in 2020 op 3 ha. Dat heeft enerzijds te maken met een weinig ontwikkelde markt voor biologische snijbloemen en anderzijds met de eisen die aan biologische producten gesteld worden, vooral in verband met exportmogelijkheden (fytosanitaire eisen derde landen; 0-tolerantie voor quarantaineorganismen evenals 0 -tolerantie op productkwaliteit). Biologisch geteelde snijbloemen zijn

${ }^{26}$ Deze tekst is vrijwel volledig afkomstig uit Bremmer et al. (2019), de data zijn geactualiseerd. 
daarom alleen geschikt voor de lokale markt. Met name de eis dat de teelt plaats dient te vinden in grond is de oorzaak dat niet veel bedrijven kiezen voor een biologische teeltwijze.

Bedrijfsgrootte, opvolging, inkomen

Het areaal snijbloementeelt onder glas op gespecialiseerde snijbloembedrijven is toegenomen, van 1.675 ha in 2010 naar 1.767 ha in 2020 (C17). Het aantal bedrijven is afgenomen, in 2010 waren er 1.500 bedrijven, in 2020 was dit gedaald tot 921 (C.12). Het gemiddelde areaal per bedrijf nam toe van 3,4 ha in 2010 tot 5 ha in 2020.

De structuur aan de hand van de verdeling van het areaal totale oppervlakte (onder glas en open grond) per grootteklasse (aantal bedrijven) laat zien dat het aantal bedrijven met minder dan 5 ha sterk is gedaald, de overige categorieën zijn stabieler in omvang (C12). De grootste bedrijven in ha gemeten zijn bedrijven die zeer intensief bolbloemen trekken op een beperkte oppervlakte onder glas en daarnaast een veel groter areaal hebben waarop bloembollen buiten geteeld worden.

Het aantal opvolgers ligt met $20 \%$ lager dan voor de totale land- en tuinbouw (zie bijlage 1 , tabel C.16). Dit percentage geldt voor persoonlijke ondernemingen. Als bv's worden meegenomen is het aandeel opvolgers hoger, maar aan ondernemers in een bv wordt in de Landbouwtelling de vraag of er een opvolger is niet gesteld, data zijn daarom niet voorhanden. In 2019 bedroeg het aandeel bedrijven met een rechtspersoon in de glastuinbouw $45 \%$.

De netto toegevoegde waarde tegen factorkosten (C.24), de beloning voor de inzet van de productiefactoren arbeid, grond en kapitaal, ligt gemiddeld wat lager dan in de andere sectoren van de land- en tuinbouw. Dit is toe te schrijven aan het relatief grote aandeel niet-gezinsarbeid.

$\mathrm{Na}$ aftrek van de betaalde factorkosten resteert het inkomen voor de ondernemer, dat wil zeggen de beloning van de inzet van eigen arbeid, kapitaal en grond (indicator C.25). Dit inkomen ligt - evenals in de glasgroentesector - aanmerkelijk hoger dan voor de akkerbouw en de melkveehouderij.

\section{Aantal bedrijven, areaal en areaal per bedrijf}

Glassnijbloemen, totaal

$\begin{array}{llll}4.800 & 6.000 & 3,00\end{array}$

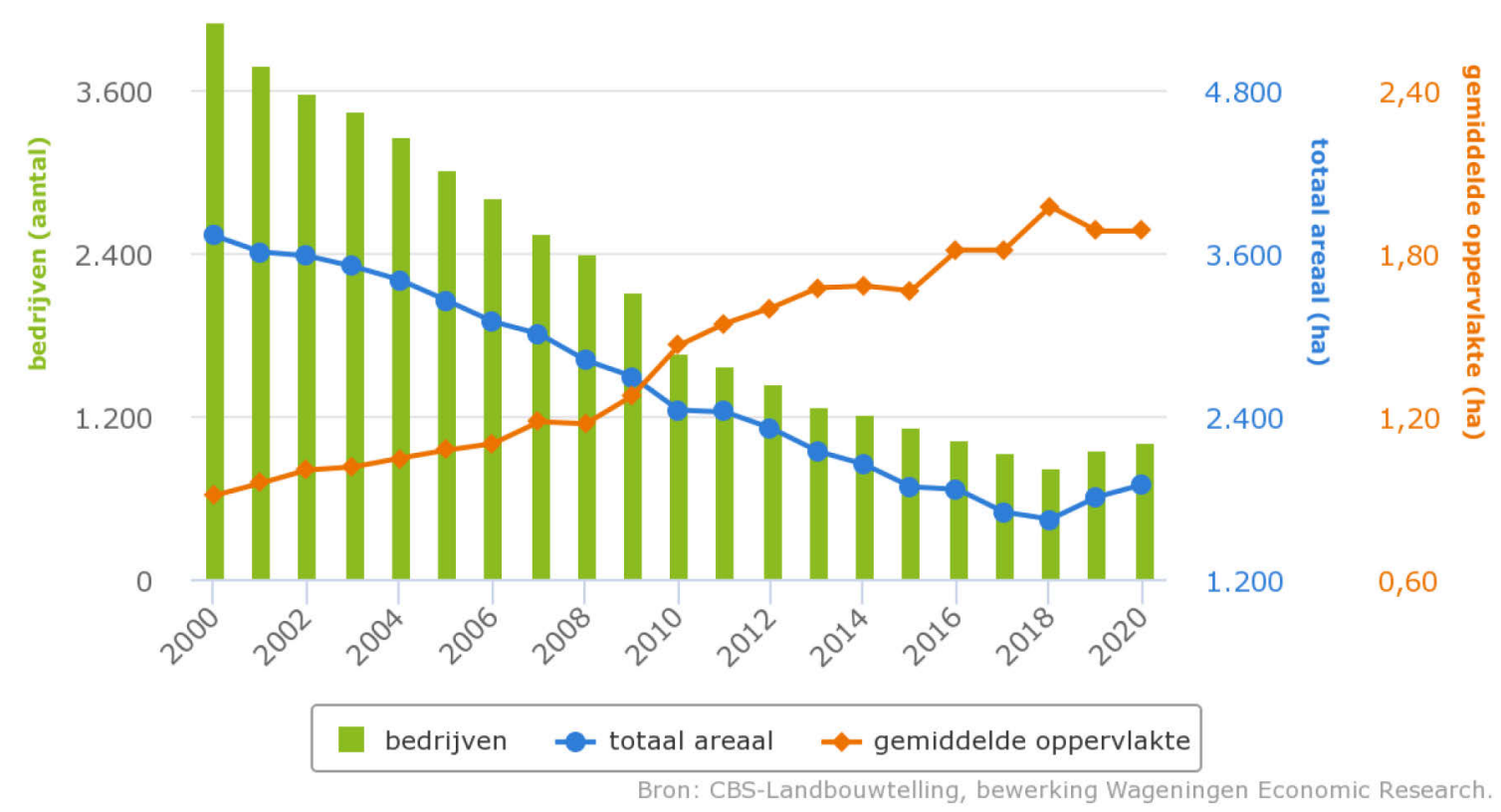

Figuur 1 Aantal bedrijven met glassnijbloemen, areaal en areaal per bedrijf. N.B. cijfers kunnen afwijken van in de tekst genoemde, omdat hier alle bedrijven met glassnijbloemen worden meegenomen, net enkel de gespecialiseerde glassnijbloembedrijven 
Netto toegevoegde waarde en werkgelegenheid snijbloemencomplex

Er zijn geen gegevens beschikbaar over de bijdrage van het snijbloemencomplex aan de netto toegevoegd waarde en de werkgelegenheid. Deze zijn er wel voor het glastuinbouwcomplex, waarvan de snijbloemen onderdeel is. ${ }^{27}$

De toegevoegde waarde van het glastuinbouwcomplex bedroeg in 2018 - het meest recente jaar waarvoor de cijfers beschikbaar zijn - ongeveer $€ 7,3$ miljard. Dat is $0,9 \%$ van het bruto binnenlands product (bbp). Een klein deel (0,4 miljard euro) van de toegevoegde waarde van het glastuinbouwcomplex wordt gerealiseerd door de verwerking van buitenlandse agrarische grondstoffen en de daarmee samenhangende toelevering en distributie.

Het op binnenlandse agrarische grondstoffen gebaseerde deel van de toegevoegde waarde (6,9 miljard euro) wordt voor bijna twee derde geleverd door de primaire bedrijven. In tegenstelling tot de andere deelcomplexen van de agrosector, is het aandeel van de primaire sector in het totaal de afgelopen jaren gegroeid. Ook toelevering heeft met $24 \%$ een behoorlijk aandeel in de toegevoegde waarde. De aandelen van verwerking en distributie zijn klein en bedragen enkele procenten.

Het glastuinbouwcomplex is sterk afhankelijk van de export. Circa 85\% van de toegevoegde waarde van het glastuinbouwcomplex hangt samen met de export van groenten, bloemen en planten.

De werkgelegenheid in het glastuinbouwcomplex is na een daling sinds 2014 voor het tweede jaar op rij weer gegroeid tot ruim 85.000 arbeidsjaren, 1,1\% van de nationale werkgelegenheid. Primaire bedrijven verschaffen binnen het op binnenlandse grondstoffen gebaseerde glastuinbouwcomplex de meeste werkgelegenheid: 65\%. Dit komt overeen met het aandeel in de toegevoegde waarde. De overige werkgelegenheid in het op binnenlandse grondstoffen gebaseerde glastuinbouwcomplex wordt grotendeels geleverd door toeleveranciers (25\%), terwijl verwerking en distributie elk een bijdrage hebben van respectievelijk $7 \%$ en $3 \%$ van de werkgelegenheid.

\section{Handelspositie}

Van de binnenlandse productiewaarde is in 2019 naar schatting $€ 2,7$ miljard via de veiling verhandeld. In Nederland zijn twee bloemenveilingen, Royal flora Holland en Plantion, waarbij eerst genoemde 98,5\% van de omzet verwerkt. De exportwaarde bedroeg in $2020 € 3,8$ miljard (Royal Flora Holland, 2020). 


\subsection{SWOT-analyse per specifieke doelstelling}

\section{(a) Bieden van steun met het oog op een leefbaar landbouwinkomen en veerkracht in de hele Unie om de voedselzekerheid te vergroten;}

SWOT-samenvatting subdoelstelling A Bieden van steun met het oog op een leefbaar landbouwinkomen en veerkracht in de hele Europese Unie om de voedselzekerheid te vergroten

\begin{tabular}{|c|c|}
\hline Sterke punten & Zwakke punten \\
\hline $\begin{array}{l}\text { - Productieomstandigheden, infrastructuur } \\
\text { - Opleidingsniveau, kennisnetwerk } \\
\text { - Innovatief vermogen } \\
\text { - Veerkracht } \\
\text { - Hoge productiviteit per ha } \\
\text { - Inkomen stabiel hoog in Nederland de laatste vijf jaar } \\
\text { - (ondanks corona) } \\
\text { - Sterke exportpositie, vooral binnen EU } \\
\text { - Sterke positie van veredelaars en andere ketenpartijen in } \\
\text { - Finternationale ketens } \\
\text { - Samenwële weerbaarbaarheid } \\
\text { - Flexibiliteit om op korte termijn in te kunnen spelen op } \\
\text { veranderende marktsituaties } \\
\text { - Breedte van het assortiment }\end{array}$ & $\begin{array}{l}\text { - Hoge kostprijs als gevolg van dure grond en arbeid } \\
\text { - Sterke vermogenspositie bemoeilijkt bedrijfsovernames } \\
\text { - Rendement op eigen vermogen en arbeid lager dan in } \\
\text { sectoren buiten de landbouw } \\
\text { - Vrij grote afhankelijkheid van de Duitse exportmarkt } \\
\text { (circa 33\%) } \\
\text { - De afhankelijkheid van elders geproduceerd } \\
\text { - } \text { - Kostantmateriaal }\end{array}$ \\
\hline Kansen & Bedreigingen \\
\hline $\begin{array}{l}\text { - Nieuwe afzetmarkten en ontwikkeling bestaande } \\
\text { - Toenetmarkten } \\
\text { - hoe dit na corona verder gaat) } \\
\text { - Onderscheidend vermogen op gebied van duurzaamheid } \\
\text { (voorwaarde; universele score en controle) } \\
\text { - Ontwikkeling nieuwe producten - variëteiten en } \\
\text { - } \text { - Roepassingen } \\
\text { - Verwaarden van gewasresten (circulaire economie) }\end{array}$ & $\begin{array}{l}\text { - Bedrijfsovername niet eenvoudig door kapitaalintensiteit } \\
\text { - } \text { Na bedrijven } \\
\text { lastig gegeven zware financiering } \\
\text { - Financieringslasten bij overname } \\
\text { - De afhankelijkheid van gewasbeschermingsmiddelen om } \\
\text { nul-tolerantie (fytosanitaire eis importerend land) voor } \\
\text { - } \text { binnenlandse markten en exportmarkten te bereiken } \\
\text { - Verschraling van het assortiment } \\
\text { - Hoge lonen } \\
\text { - Afhankelijkheid van de conjunctuur }\end{array}$ \\
\hline
\end{tabular}

\section{Sterktes}

Het gemiddelde inkomen van ondernemers met snijbloemenbedrijven behoort de laatste vijf jaar tot de hoogste in de gehele agrarische sector (inkomen per onbetaalde arbeidskracht) en ligt ruim boven de $€ 100.000$. Ondanks dit gegeven verkeert een aantal bedrijven in zwaar weer (van der Meulen et al., 2020).

In het verleden is gebleken dat individuele bedrijven in staat zijn in te spelen op veranderende marktsituaties, eventueel in samenwerking met andere bedrijven, zoals ten tijde van de eerste coronagolf is gebleken. Bij het geheel of gedeeltelijk wegvallen van markten of veranderende vraag van markten wordt daarop ingespeeld door snel andere kanalen/markten te zoeken. Een vanuit marketingoogpunt sterk punt van de Nederlandse snijbloementeelt is het jaarrond kunnen aanbieden van een breed sortiment van verschillende typen snijbloemen en per snijbloem verschillende rassen. Weliswaar zijn teeltbedrijven gespecialiseerd voor één gewas, de handel is goed in staat het sortiment bijeen te brengen.

De laatste veertig jaar is de wijze van telen in de snijbloementeelt enorm veranderd. Illustratief is de wijze waarop in de jaren tachtig is omgegaan met het verbod op het gebruik van methylbromide om bodemaaltjes te bestrijden. Het antwoord van de sector was teelt op substraat. 
Door de gemiddeld goede bedrijfsresultaten in de laatste vijf jaar, is de gemiddelde vermogenspositie en daarmee de financiële weerbaarheid, aanmerkelijk verbeterd. De gemiddelde solvabiliteit bedroeg in 2019 56\% tegenover 32\% in 2013 (van der Meulen et al., 2020).

Niet van toepassing:

- hoge productiviteit per dier;

- gezinsbedrijf dominant.

\section{Zwaktes}

De Nederlandse snijbloementeelt is afhankelijk van energie om in de winter een aanvaardbare productkwaliteit te kunnen realiseren. Daar speelt het toepassen van assimilatiebelichting een belangrijke rol bij.

Het uitgangsmateriaal voor snijbloemengewassen wordt door Nederlandse bedrijven geproduceerd in Afrika. De reden is dat tegen een lagere kostprijs kwalitatief betere planten geproduceerd kunnen worden. De coronacrisis heeft duidelijk gemaakt dat hier het risico van leveringszekerheid mee verbonden is.

De kostprijs is een belangrijke concurrentiefactor in de internationale handel van bloemen. Productkwaliteit en kostprijs zijn vaak verbonden en worden door marktvraag bepaald. Snijbloemen vallen onder de categorie 'luxe producten' met een hoge prijselasticiteit. Voor de afzet van bloemen houdt dit in dat als het slechter gaat met de economie prijzen snel zullen dalen. De markt tijdens de eerste coronagolf is hiervoor illustratief. Als inkomensverwachtingen verbeteren, stijgen prijzen ook weer snel.

\section{Kansen}

Het ontwikkelen van nieuwe afzetmarkten is niet eenvoudig. De welvaartstandaard per land kan enorm verschillen en daarmee ook de verkoopmogelijkheden. De ontwikkeling van de export naar Polen is een goed voorbeeld van een markt die recent tot ontwikkeling is gekomen. Polen houden van oudsher altijd al van bloemen, maar doordat er per inwoner meer geld te besteden is, is de markt tot wasdom gekomen.

Internetverkopen nemen toe, met name ook door de uitbraak van de corona-pandemie. Het is moeilijk in te schatten of dit zo zal blijven als de corona-pandemie voorbij is.

Onder invloed van de publieke opinie is het verkoopargument 'duurzaam geproduceerd' steeds belangijker geworden en de verwachting is dat dit, vooral ook in internationaal perspectief, steeds belangrijker gaat worden. Het gaat dan vooral om het steeds verder terugdringen van de negatieve externe effecten van de productie (emissies), niet zo zeer om biologische teelt. Bedrijven die zich qua duurzaamheid weten te onderscheiden, zullen hier bij het vermarkten van hun producten steeds meer voordeel van ondervinden. Duurzaamheid is belangrijke factor in aankoopbeslissing. Bij bloemen en planten wordt duurzaamheid meegenomen in de aankoopbeslissing van consumenten. Uit onderzoek van ABN AMRO blijkt dat bijna $70 \%$ van de consumenten in Nederland en veel belangrijke afzetlanden enigszins tot veel belang hecht aan de duurzaamheid van bloemen en planten (Zevenbergen, 2021).

In 2013 is het Floriculture Sustainability Initiative (FSI) opgezet om transparantie te krijgen in de keten van verschillende duurzaamheidscertificaten door een benchmark mechanisme en om certificering te bevorderen. De ambitie van FSI is gecentreerd rond drie pijlers - verantwoorde productie en handel, verantwoord gedrag en geïntegreerde verslaglegging - plus het FSI-governance kader, dat een alomvattende benadering van de duurzaamheid van de toeleveringsketen biedt. De ambitie is dat $90 \%$ van de verhandelde bloemen voldoet aan de door FSI gestelde duurzaamheidseisen. Op dit moment is dit ongeveer 70\% (FSI, 2020).

Biologische snijbloementeelt heeft in Nederland nooit een grote vlucht genomen. De redenen zijn dat verreweg de meeste snijbloemen op substraat worden geteeld, wat volgens de normen niet onder biologisch valt. Ook de focus op export maakt het lastiger, omdat biologisch geteelde bloemen bijna nooit aan de fytosanitaire normen voor export voldoen. 
Over een reeks van jaren hebben Nederlandse snijbloemen telers nieuwe producten en toepassingsmogelijkheden geïntroduceerd. Continue productvernieuwing is nodig en is een stimulans voor de afzet van snijbloemen. Het is een proces waar veel inzet en tijd mee gemoeid is.

Economisch gezien zijn bloemen luxe producten, dat wil zeggen producten die niet noodzakelijk zijn voor het eerste levensonderhoud. Bloemen zijn producten met een hoge prijselasticiteit. Marktbureau GfK berekende in 2021 een prijselasticiteit van -1,59. Deze producten kenmerken zich ook door relatief heftige reacties op veranderingen in de markt. Een verlaging van de conjunctuur zal leiden tot relatief heftige prijsdaling.

ABN AMRO verwacht dat het verwaarden van gewasresten in 2030 ongeveer $5 \%$ van de omzet uit zal maken (Zevenbergen, 2021).

Niet van toepassing:

- Vraag naar publieke diensten (nieuw GLB);

- Sterke verstedelijking van het Nederlandse platteland geeft kansen voor directe verbindingen met de stad via het leveren van producten en diensten;

- Inzet Platform Multifunctionele Landbouw om knelpunten in ontwikkeling multifunctionele landbouw weg te nemen en ontwikkelruimte te creëren;

- Aandacht voor het vergroten van veerkracht;

- Subsidiemodule agrarische bedrijfsadvisering en educatie (SABE-regeling).

\section{Bedreigingen}

Voor de afzet van snijbloemen is export essentieel, er wordt meer geproduceerd dan op de nationale markt kan worden afgezet. Om toegang tot markten te behouden, moet worden voldaan aan fytosanitaire eisen. Voor het uitsluiten van de aanwezigheid van quarantaine organismen zijn goede chemische middelen onontbeerlijk. Het nationale beleid is er echter op gericht het aantal beschikbare middelen te beperken. Hier is dus een spanningsveld.

Nederlandse snijbloemen worden voor het grootste gedeelte geëxporteerd naar landen binnen de EU. VK is nu het belangrijkste exportland buiten de EU (derde plaats). Het al dan niet goed kunnen exporteren is van doorslaggevende betekenis voor te behalen inkomens op snijbloemen telende bedrijven. De gevolgen die Brexit heeft op de export naar het VK zijn nog onzeker.

De verschuiving van afzet van bloemenwinkels naar retailers, bouwmarkten en online-afzet, heeft ertoe bijgedragen dat de vraag naar grote uniforme partijen is toegenomen. Daarin is steeds minder plaats voor kleine nicheproducten. Dit wordt door de sector en de bloemenveiling als een bedreiging gezien (Bremmer et al., 2019).

Verschraling van het chemische middelenpakket leidt tot meer fytosanitaire problemen en kwaliteitsproblemen. Biologische middelen zijn op dit moment nog niet toereikend om zogenaamde quarantaine-organismen $100 \%$ te bestrijden. Deze nul-tolerantie is wel vereist voor de export naar derde landen.

Lonen stijgen autonoom en daarbij is het voor glastuinbouwbedrijven moeilijk om aan kwalitatief goede arbeid te komen. Er is een tendens vaste arbeidskrachten te vervangen door losse arbeid om de flexibiliteit groter te maken. Robotisering zou in de toekomst voor verlichting kunnen zorgen. In de arbeid op veel snijbloemenbedrijven wordt voor een belangrijk deel voorzien met buitenlandse arbeidskrachten. Het is voor veel bedrijven lastig aan kwalitatief goede arbeidskrachten te komen. Daarbij is arbeid een belangrijke kostenpost. Door robotisering wordt arbeid vervangen door een robot, dus kapitaal vervangt arbeid. Dit biedt kansen de kostprijs te verlagen en het werk op uniforme wijze uit te voeren.

Assimilatiebelichting is een algemeen toegepaste investering in de snijbloementeelt. Dit vraagt aan de ene kant veel extra energie en levert aan de andere kant meer en kwalitatief betere bloemen in de winter op. Aan het toepassen van assimilatiebelichting zijn regels verbonden om op bepaalde tijden de kassen af te schermen voor lichtuitstoot. Aanscherping van deze regels leidt tot beperking van het 
aantal uren waarbij mag worden belicht met geopende schermen. Dat zal in veel gevallen leiden tot problemen met de warmtehuishouding en warmte verspilling (Westerman et al., 2005).

Niet van toepassing:

- Inkomensondersteunende en stabiliserende werking toeslagen neemt verder af. In de snijbloementeelt spelen deze geen rol. 
(b) Vergroten van de marktgerichtheid en van het concurrentievermogen, onder meer door beter te focussen op onderzoek, technologie en digitalisering;

SWOT-samenvatting subdoelstelling B - Vergroten van de marktgerichtheid en van het concurrentievermogen, onder meer door beter te focussen op onderzoek, technologie en digitalisering

\begin{tabular}{|c|c|}
\hline & \\
\hline $\begin{array}{l}\text { - Goede uitgangspositie logistiek, infrastructuur, organisatie } \\
\text { - Hectoren } \\
\text { - kennis } \\
\text { - Sterke Groei R\&D agribusiness, toename innovatief } \\
\text { vermogen } \\
\text { - Duurzame investeringen op koers } \\
\text { - Beleid Topsectoren } \\
\text { - Innovaties in technieken, producten, processen } \\
\text { - Organisatievermogen, samenwerking en innovatiekracht } \\
\text { - } \text { sector } \\
\text { - Kelatief lage koste afstanden tot belangrijkste afzetgebieden } \\
\text { - Specialisatie van productiebedrijven }\end{array}$ & $\begin{array}{l}\text { - Grootschaligheid en intensiteit productie } \\
\text { - Wet van de remmende voorsprong: toenemende druk } \\
\text { afgelopen jaren op concurrentiepositie voor meerdere } \\
\text { producten } \\
\text { - Hoge wet- en regelgevingsdruk, deels bovenwettelijk, met } \\
\text { nauwelijks verwaarding van de extra kosten } \\
\text { - Hoge financieringslasten beperken } \\
\text { ontwikkelingsmogelijkheden (met name middengroep) } \\
\text { - Afhankelijkheid van bepaalde handelsbedrijven van één of } \\
\text { enkele markten } \\
\text { - Afhankelijkheid van conjunctuur }\end{array}$ \\
\hline Kansen & \\
\hline $\begin{array}{l}\text { - Toenemende vraag maatschappij naar duurzame(re) } \\
\text { producten } \\
\text { - Vraag naar bedrijfssystemen met minder externe effecten } \\
\text { (kringlopen) } \\
\text { - Ontwikkelen van nieuwe markten en marktkanalen } \\
\text { - Verbeteren productkwaliteit } \\
\text { - Universele duurzaamheidsscore - controleerbaar }\end{array}$ & $\begin{array}{l}\text { - Maatschappelijk draagvlak voor de huidige } \\
\text { - Vroductiemethoden neemt af } \\
\text { landbouwmodel } \\
\text { - Digitalisering op bedrijven vindt plaats in verschillende } \\
\text { snelheden Beschikbaarheid van voldoende arbeid (op alle } \\
\text { niveau's, ook midden- en hoger kader) } \\
\text { - Verschraling assortiment } \\
\text { - Verschraling aantal handelsbedrijven } \\
\text { - Residu metingen - kosten - winst -> prijs } \\
\text { - Gebruik (illegaal) van niet toegestane stoffen }\end{array}$ \\
\hline
\end{tabular}

De snijbloemenmarkt is een sterk internationaal georiënteerde markt met internationale concurrentie en Nederlandse exportbelangen. Snijbloemen worden voor import vanuit m.n. Afrika veelal via luchttransport verplaatst. De coronacrisis heeft duidelijk gemaakt dat deze afhankelijkheid tevens een kwetsbaarheid inhoudt. In deze internationaal georiënteerde markt heeft Nederland van oudsher een sterke positie, die de laatste twintig jaar wel sterk veranderd is. De snijbloementeelt in Afrikaanse landen is tot ontwikkeling gekomen en Afrikaanse bloemen worden voor een belangrijk deel op de West-Europese markt worden afgezet. Snijbloemenbedrijven steken zelf veel meer energie dan voorheen in het vermarkten van hun producten.

Nederland ligt topografisch gunstig ten opzichte van grote stedelijke centra in Europa en heeft logistiek die geschikt is voor de snelle verwerking van bloemen. Deze voordelen wegen niet altijd op tegen het nadeel van de kostenopbouw van Nederlandse snijbloemen. Ten opzichte van Afrika en Zuid-Amerika is arbeid in Nederland relatief duur, evenals energie. Vooral door het toepassen van assimilatiebelichting is bij de huidige wijze van telen veel energie nodig. Assimilatiebelichting is geïntroduceerd en geïntensiveerd om in de wintermaanden kwalitatief te kunnen wedijveren met snijbloemen uit zuidelijk gelegen landen en meer te kunnen produceren in maanden waarin de prijzen relatief hoog zijn.

\section{Sterktes}

Jarenlange handelsrelaties zijn vaak gebaseerd op een door jarenlange samenwerking ontstaan vertrouwen. Nederlandse handelsbedrijven, die veelal internationaal opereren, hebben een enorm netwerk van relaties opgebouwd.

De factor tijd is verbonden met afstand en productkwaliteit. Korte afstanden tot de belangrijkste afzetgebieden zijn nog steeds een belangrijk voordeel van in Nederland geproduceerde bloemen. 
Nederlandse bedrijven werken over het algemeen efficiënt en weten de kostprijs zo laag mogelijk te houden, wat in de hand wordt gewerkt doordat Nederlandse snijbloemenbedrijven gespecialiseerd zijn. Dit gaat gepaard met een over het algemeen goede prijs. Desalniettemin is het voor Nederlandse rozentelers op internationale markten lastig op te boksen tegen met name in Afrika geproduceerde bloemen, met name rozen. Dit wordt geïllustreerd door de teruggang van het Nederlandse rozenareaal de laatste vijftien jaar (CBS-statline).

\section{Zwaktes}

Met name kleinere en middelgrote exporterende handelsbedrijven hebben vaak één of een paar grote klanten. Hoewel het vaak om in jaren opgebouwde handelsrelaties gaat, is dit risicovol.

Crises in de wereldeconomie hebben een grote impact op de handel in snijbloemen en daarmee op de inkomens van snijbloemenbedrijven. De monetaire crisis na 2008 is hiervan een voorbeeld.

\section{Niet van toepassing:}

- Hoge grondprijzen, die mede leiden tot kostprijsverhoging bij extensivering. Extensivering speelt geen rol bij de snijbloementeelt.

\section{Kansen}

Consumentenaankopen bepalen uiteindelijk de verkoop van bloemen en hun toepassingen, bijvoorbeeld de samenstelling van gemengde boeketten. Nieuwe markten en marktkanalen kunnen bijdragen aan productvernieuwing en het meer aansluiten van wensen en aanbod.

Productkwaliteit is een essentieel concurrentie-aspect. Alleen een bevredigende kwaliteit is voor consumenten aanleiding tot herhaalaankopen. Juist een zo constant mogelijke kwaliteit wordt door de handel zeer belangrijk geacht (Benninga et al., 2015).

Duurzaamheid is een steeds belangrijker aankoopcriterium voor handel en consumenten geworden. Om herkomst van bloemen te kunnen vergelijken en afweging te kunnen maken, is een universeel gedragen objectieve duurzaamheidsscore van groot belang. Eerste voorwaarde van zo'n score is, dat deze controleerbaar is. Hiertoe is de HortiFootPrint ontwikkeld in samenwerking met WUR. Bovendien wordt deze methodologie ook ontwikkeld tot een Europese PEFCR-standaard om controleerbaarheid en vergelijkbaarheid te vergroten.

\section{Niet van toepassing:}

- Instituties in en om de landbouw meer aandacht voor andere vormen van landbouw dan de klassieke op kostprijsverlaging gerichte modellen

- Stimuleren natuurinclusieve landbouw, zoals Green Deal Natuurincl. landbouw

\section{Bedreigingen}

Eén van de krachten van het Nederlandse snijbloemenaanbod, is de breedte van het assortiment. Nicheproducten worden vaak door relatief kleine bedrijven geteeld. Juist voor deze bedrijven wordt het steeds lastiger hun vaak kleine partijen af te zetten, zonder dat de kosten de pan uit rijzen.

Het aantal exporterende handelsbedrijven is sterk aan het afnemen. Dit komt de prijsvorming niet ten goede.

'Wilde' ad hoc residu metingen door milieu-organisaties hebben in het verleden stoffen op bloemen en planten aangetoond die al lang niet meer in Nederland toegelaten zijn. Het illegaal toepassen van zeer schadelijke stoffen, is zeer slecht voor het imago en de verkoop van Nederlandse bloemen, zeker als de publieke media daarover publiceren. Voor zover bekend hebben dit soort excessen zich het laatste jaar niet voorgedaan.

Niet van toepassing:

- Bereidheid consumenten te betalen voor een duurzame plus vooralsnog beperkt

- Import van goedkopere grondstoffen

- Onvoldoende positieve prikkels vanuit keten voor digitalisering

- Verdere druk op concurrentiepositie door de landbouwontwikkeling in veel landen 


\section{(c) Verbeteren van de positie van de landbouwers in de waardeketen;}

SWOT-samenvatting subdoelstelling C Verbeteren van de positie van de landbouwers in de waardeketen

$\begin{array}{ll}\text { Sterke punten } & \text { Zwakke punten } \\ \text { - Hoog kennis- en opleidingsniveau } & \text { - Vermindering van het aantal marktpartijen } \\ \text { - Uitgebreid kennisnetwerk dat kan bijdragen } & \text { - Vermindering van het belang van het } \\ \text { - Goed ondernemerschap } & \begin{array}{c}\text { prijsvormingsinstrument 'klassieke veilingklok' } \\ \text { - Innovatiekracht }\end{array} \\ \text { - Logistiek } & \begin{array}{l}\text { Verhandelen van grote partijen via 'klok' is niet goed } \\ \text { - Marktvorm volledige mededinging -> zo optimaal mogelijke }\end{array} \\ \text { - prijsvorming } & \\ \text { - Samenwerking in de vorm van telersverenigingen } & \\ \text { Kansen } & \text { Bedreigingen } \\ \text { - Samenwerking tussen productie bedrijven } & \text { - Verdwijnen van 'Klok' als prijsvormings- instrument } \\ \text { - Ketenintegratie } & \\ \text { - Digitaal handelsplatform (Floriday) } & \end{array}$

\section{Sterktes}

De huidige marktvorm wordt als een markt van volledige mededinging betiteld, dat wil zeggen een markt met veel aanbieders en vragers. In de loop van de tijd is het prijsmechanisme van 'de veilingklok' wel steeds verder uitgehold. Enerzijds is het aantal handelsbedrijven sterk afgenomen, anderzijds is het aantal aanbieders afgenomen en worden steeds meer partijen buiten de veiling om verhandeld.

Wat betreft de afzet bundelen bedrijven hun krachten ten opzichte van handel en retail, maar de afzet is via de veiling. Veel bedrijven hebben hun afzet collectief geregeld in een samenwerkingsverband. Dit is in de snijbloementeelt meestal productgebonden. Zo zijn er telersverenigingen van chrysant, snij-anthurium en cymbidium.

Niet van toepassing:

- Dichtbij afzetmarkt - kleine afstand stad/land

- Opkomst korte ketens

- Groei multifunctionele landbouw, met Boer-burger contact

\section{Zwaktes}

Alle punten uit de SWOT zijn aangepast omdat deze niet relevant zijn voor de snijbloementeelt.

De vermindering van het aantal marktpartijen en de uitholling van het veilingklokmechanisme, zou uit oogpunt van optimale prijsvorming als een zwakte kunnen worden beschouwd. Doordat steeds meer transacties buiten de veiling om plaatsvinden, is de markt minder transparant geworden. Vooral voor kleinere productiebedrijven is dit nadelig, zij hebben in tegenstelling tot de grote bedrijven geen alternatieve afzetkanalen.

Het verschuiven van steeds meer afzet naar retail en bouwmarkten (Royal Flora Holland/Bureau sierteelt, 2015) heeft als gevolg dat er steeds meer vraag is naar grote uniforme partijen. De snijbloemensector heeft voor een aantal producten en in het winterhalfjaar moeite om aan deze vraag te voldoen.

\section{Kansen}

Alle punten uit de SWOT zijn aangepast omdat deze niet relevant zijn voor de snijbloementeelt.

Samenwerking tussen productiebedrijven om grote partijen van zo gelijk mogelijke kwaliteit te kunnen verkopen is een kans die feitelijk voor een deel realiteit geworden is. Ketenintegratie, waarbij gesloten ketens ontstaan van veredeling tot en met afzet, biedt bedrijven de mogelijkheid zich in de markt te onderscheiden. 
De oprichting van het digitaal handelsplatform Floriday biedt telers mogelijkheden om commerciële processen efficiënter in te richten. Kopers hebben via dit platform toegang tot een breed en diep assortiment.

\section{Bedreigingen}

Alle punten uit de SWOT zijn aangepast omdat deze niet relevant zijn voor de snijbloementeelt.

Het verdwijnen van de 'Klok' als prijsvormingsinstrument op de grootste bloemenveiling Royal Flora Holland wordt vooral door de kleinere productiebedrijven die geen alternatieve afzetkanalen hebben, als een bedreiging gezien. 


\section{(d) Bijdragen tot matiging van en aanpassing aan klimaatverandering en tot duurzame energie;}

SWOT-samenvatting subdoelstelling D Bijdragen aan mitigatie en adaptatie aan klimaatverandering en leveren van een bijdrage aan een duurzame energieproductie

\begin{tabular}{|c|c|}
\hline Sterke punten & Zwakke punten \\
\hline $\begin{array}{l}\text { - Veel mogelijkheden voor klimaatadaptatie en -mitigatie } \\
\text { - Kennis om te innoveren } \\
\text { - Initiatieven van ketenpartijen } \\
\text { - Gesloten teeltsystemen }\end{array}$ & $\begin{array}{l}\text { - Goedkope fossiele brandstoffen vertragen transitie naar } \\
\text { duurzame energiebronnen. Overheidsbeleid, zoals de ODE } \\
\text { - Toepassing van wind- en zonne-energie is nog afhankelijk } \\
\text { van subsidies } \\
\text { - Uitstoot broeikasgassen relatief hoog } \\
\text { - De afhankelijkheid van energie om enerzijds kassen te } \\
\text { verwarmen en anderzijds in de winter gewassen te } \\
\text { belichten }\end{array}$ \\
\hline Kansen & Bedreigingen \\
\hline $\begin{array}{l}\text { - (Onderzoek naar) Nieuwe en innovatieve } \\
\text { bedrijfssystemen } \\
\text { - (Onderzoek naar) Energiebesparing op bedrijven } \\
\text { - Initiatieven van het bedrijfsleven } \\
\text { - Koploper worden in klimaatneutrale land- en tuinbouw } \\
\text { - Stijging buitentemperatuur }\end{array}$ & $\begin{array}{l}\text { - Toenemende concurrentie om de grond (ruimteclaims) } \\
\text { - Doorgaande klimaatverandering: stijging } \\
\text { buitentemperatuur leidt tot hogere druk ziekten en plagen } \\
\text { - Toename frequentie hoge buitentemperatuur leidt tot } \\
\text { productie- en kwaliteitsverlies } \\
\text { - Verzilting van het grond- en oppervlaktewater } \\
\text { - Overheidsbeleid ten aanzien van duurzame energie }\end{array}$ \\
\hline
\end{tabular}

\section{Sterktes}

De Nederlandse glastuinbouw is bezig met een transitieproces naar alternatieve energie bronnen. Op dit moment is een afname van de $\mathrm{CO}_{2}$-emissie bereikt van $14 \%$ t.o.v. het niveau van 1990 (inclusief $\mathrm{CO}_{2}$-emissie voor elektriciteit productie) voor de hele glastuinbouw. De laatste jaren is de $\mathrm{CO}_{2}$-emissie stabiel en in 2019 zelfs iets gestegen. (van der Velden et al., 2020).

Niet van toepassing:

- Publiek-private samenwerking om klimaatopties toe te passen die in te passen zijn in de bedrijfsvoering

\section{Zwaktes}

De afhankelijkheid van energie om in het winter halfjaar bloemen te kunnen telen impliceert het risico van leveringszekerheid en dat de energieprijs grote invloed heeft op de totale kosten en daarmee de concurrentiekracht.

De huidige wijze van telen is energie-intensief en daarmee zijn snijbloemenbedrijven afhankelijk van energievoorziening en energieprijzen. De opkomst van alternatieve energiebronnen, met name aardwarmte, is wat dit betreft hoopvol.

De energiekosten zijn voor de snijbloementeelt in kassen een belangrijke kostenpost. De verwachting dat energieprijzen zullen stijgen is reëel, gezien de eisen aan vermindering van de $\mathrm{CO}_{2}$-uitstoot en het stoppen van Nederlandse aardgaswinning.

Niet van toepassing:

- Teelt biomassa kan niet concurreren met teelt akkerbouwgewassen

- Belemmeringen op het vlak van afval- en mestwetgeving staan hergebruik van stoffen in de weg

\section{Kansen}

Door de wereldwijde stijging van de gemiddelde buitentemperatuur, wordt de afhankelijkheid van energie voor kasteelten kleiner. Wel nemen de weersextremen toe, dat als een bedreiging kan worden gezien. 


\section{Bedreigingen}

Stijging buitentemperatuur leidt tot een hogere plagendruk waaronder van organismen die op de fytosanitaire quarantainelijsten staan. Met een hoger wordende gemiddelde buitentemperatuur neemt de frequentie en de hoogte van extreem hoge temperaturen ook toe. Extreem hoge temperaturen leiden tot productie- en kwaliteitsverlies in de periode daarna. Een goede tot aanvaardbare kwaliteit is moeilijker te realiseren na extreem hoge temperaturen. Ten slotte gaan hoge temperaturen vaak samen met een periode van droogte. Hierdoor kan de beschikbaarheid van kwalitatief goed water een probleem worden.

De glastuinbouwsector is gestimuleerd om over te stappen van gas op elektra. De recente heffing Opslag Duurzame Energie, die voortvloeit uit de Wet fiscale maatregelen Klimaatakkoord, betekent voor grootverbruikers van elektriciteit een forse heffing en daarmee een forse kostenverhoging van ingekochte elektriciteit. Bedrijven met een verbruik tussen 50.000 tot 10 miljoen kWh per jaar krijgen een tariefstijging van bijna $180 \%$. In deze verbruikscategorie valt een groot deel van de glastuinbouwbedrijven. Glastuinbouwbedrijven zijn dan ook heffing plichtig, ongeacht of ze reguliere of groene stroom gebruiken. Door deze heffing wordt gas voor grootverbruikers goedkoper. Voor duurzaamheid of vanuit klimaatdoelen kan dit ook contraproductief zijn als bedrijven van elektra omschakelen naar gas vanuit financiële overwegingen, terwijl ze waren overgestapt naar elektra op grond van duurzaamheidsoverwegingen. De tariefsverhoging van de ODE heeft daarnaast een averechts effect op de omschakeling van wkk-gebruik (met aardgas) naar de inkoop van elektriciteit uit het net, dat onderdeel vormt van de energietransitie naar een klimaatneutrale glastuinbouw.

Niet van toepassing:

- Business as usual in beleid en praktijk 
(e) Bevorderen van duurzame ontwikkeling en efficiënt beheer van natuurlijke hulpbronnen zoals water, bodem en lucht;

SWOT-samenvatting subdoelstelling E Bevorderen van duurzame ontwikkeling en efficiënt beheer van natuurlijke hulpbronnen, zoals water, bodem en lucht

\begin{tabular}{|c|c|}
\hline Sterke punten & Zwakke punten \\
\hline $\begin{array}{l}\text { - Efficiënte productie per eenheid product } \\
\text { - Initiatieven in sector en keten om milieubelasting } \\
\text { productie terug te brengen } \\
\text { - Veel kennis in sectoren en ketens om de milieubelasting } \\
\text { te verminderen } \\
\text { - Samenwerking tussen diverse partijen in de keten om te } \\
\text { werken aan verduurzaming } \\
\text { - Belasting bodem is nihil } \\
\text { - Zelfvoorzienend in watergebruik } \\
\text { - Recirculerende teeltsystemen }\end{array}$ & $\begin{array}{l}\text { - Het afvoeren van zuiveringsextract, bij toepassing van } \\
\text { omgekeerde osmose } \\
\text { - Lozingen op oppervlaktewater vinden incidenteel plaats } \\
\text { - Residuen in oppervlaktewater } \\
\text { - Geproduceerd afval in de vorm van substraten, waaronder } \\
\text { steenwol } \\
\text { - Voor chrysant: de afhankelijkheid van remmiddelen }\end{array}$ \\
\hline Kansen & Bedreigingen \\
\hline
\end{tabular}

Snijbloemen onder glas worden voor een groot deel op substraat los van de ondergrond geteeld. Het doceren van meststoffen gebeurt computergestuurd via doseerunits. Het watergeven gebeurt met behulp van druppelsystemen. Het drainwater wordt opgevangen en gerecirculeerd. Op de meeste bedrijven wordt assimilatie belichting toegepast om in de winter een aanvaardbare kwaliteit te kunnen leveren en een hogere productie te kunnen realiseren.

\section{Sterktes}

De teelt van snijbloemen in kassen vindt veelal los van de ondergrond plaats. Daardoor wordt de bodem niet direct belast door bijvoorbeeld zware machines. Wel leggen kassen natuurlijk beslag op beschikbare ruimte.

Qua waterverbruik zijn snijbloemen bedrijven voor een groot deel zelfvoorzienend omdat ze beschikken over een waterbassin waarin regenwater wordt opgevangen. Het watergebruik wordt beperkt omdat bedrijven in de meeste gevallen gesloten telen. In perioden van droogte moet meestal (afhankelijk van bassingrootte in relatie tot beteelde oppervlakte) een beroep worden gedaan op aanvullende waterbronnen.

Een groot deel van de productie van snijbloemen in Nederland wordt geteeld op recirculerende teeltsystemen. Dit heeft als gevolg dat de emissie van schadelijke stoffen, in de vorm van resten gewasbeschermingsmiddelen en uitgespoelde zouten, aanmerkelijk is gereduceerd.

Het gesloten zijn van snijbloemenbedrijven en daarbij het vermogen om water te recirculeren, maakt dat deze bedrijven al een deel van de opgave om circulair te worden, hebben vervuld. Hier kunnen een paar kanttekeningen bij worden geplaatst:

1. Honderd procent gesloten, ook op het gebied van water, is niet mogelijk. Emissie uit kassen (m.n. grondteelten) is er altijd en overtollige zouten zullen afgevoerd dienen te worden.

2. Er zijn meer aspecten aan circulair verbonden dan alleen water. 
Niet van toepassing:

- Milieudruk grond en oppervlaktewater met gewasbeschermingsmiddelen, stikstof en fosfaat is stabiel tot afgenomen.

\section{Zwaktes}

Recirculerende systemen waarvan het zoutgehalte te hoog is opgelopen, wat in de zomer het vaakst gebeurt, dienen te worden gezuiverd van overtollige zouten, bijvoorbeeld met een omgekeerde osmose-apparaat. Het zuiveringsextract wat overblijft dient afgevoerd te worden.

Ook al is dit tot een minimum beperkt, vinden lozingen op oppervlaktewater incidenteel plaats.

Ondanks dat veel teeltsystemen recirculerend zijn, is er emissie van resten gewasbeschermingsmiddelen en meststoffen. Met name residuen gewasbeschermingsproducten op het product liggen onder het maatschappelijk vergrootglas. De afvalberg die ontstaat door gebruikte kunstmatige substraten, zoals steenwol, is een aandachtspunt. Een groot deel van deze substraten wordt gerecycled.

Van het Nederlandse snijbloemensortiment is chrysant het belangrijkste product. In de teelt van chrysanten is planbaarheid en uniformiteit van gewassen, van groot belang. Om dit zo optimaal mogelijk te kunnen realiseren worden remmiddelen toegepast. Remmiddelen zijn groeiregulatoren en vallen onder de gewasbeschermingsverordening en worden door het CTGB (College voor de Toelating van Gewasbeschermingsmiddelen en Biociden) beoordeeld op veiligheid voor mens, dier en milieu. Het gebruik van chemische remmiddelen in de chrysantenteelt is veel minder schadelijk voor het milieu dan vroeger. Er wordt al lange tijd alternatieven toegepast om het chemische gebruik terug te dringen.

Een veilige drinkwatervoorziening is van groot nationaal belang (PBL 2019). De aanwezigheid van residuen gewasbeschermingsmiddelen in oppervlaktewater is zeer slecht voor het imago van de Nederlandse snijbloementeelt. Uit de tussenrapportage van de nota gezonde groei (Spoorenberg et al., 2019) blijkt dat in 2016 het aantal problemen met gevonden chemische stoffen afkomstig van sierteelt onder glas, 46 is geweest waarbij een aantal problemen uit eerdere jaren stamt (zijn gecumuleerd). Tot en met 2015 is er ieder jaar een stijging geweest van het aantal problemen in de sierteelt onder glas. De sierteelt onder glas bestaat naast snijbloementeelt uit potplantenteelt en boomteelt onder glas.

Niet van toepassing: alle genoemde elementen in de SWOT.

\section{Kansen}

Een technische ontwikkeling van een meer op behoefte geënte watergift zal met name bij grondteelten tot minder waterverspilling leiden en vooral een verbetering van groei en ontwikkeling van de gewassen. Technische ontwikkelingen met behulp van sensoren en integratie met het kasklimaat, zijn gaande.

Nederlandse snijbloemen bedrijven werken aan het minder belasten van het milieu. Voor een deel ligt overheidsbeleid aangaande beschikbare gewasbeschermingsmiddelen hieraan ten grondslag. Dit wordt in de toekomst een bepalende concurrentiefactor, zo is de verwachting.

Niet van toepassing:

- Langzaam groeiende vraag naar duurzamer geproduceerde voedselproducten.

- Visie Kringlooplandbouw biedt een wenkend perspectief voor systeemverandering en kan als katalysator werken.

\section{Bedreigingen}

Regenwater is voor de teelt van snijbloemen kwalitatief het beste water. Perioden van droogte komen de laatste jaren frequent voor en leiden tot tekorten van kwalitatief goed water. Kwalitatief minder water leidt eerder tot zoutophoping in recirculerende systemen. 
Verschraling van het chemische middelenpakket leidt tot meer fytosanitaire en kwalitatieve problemen. Biologische middelen zijn op dit moment nog niet toereikend om zogenaamde quarantaine-organismen $100 \%$ te bestrijden.

Assimilatiebelichting is een algemeen toegepaste investering in de snijbloementeelt. Dit vraagt aan de ene kant veel extra energie en levert aan de andere kant meer en kwalitatief betere bloemen in de winter op. Aan het toepassen van assimilatiebelichting zijn regels verbonden om op bepaalde tijden de kassen af te schermen voor lichtuitstoot. Aanscherping van deze regels leidt tot beperking van het aantal uren waarbij mag worden belicht met geopende schermen.

Niet van toepassing:

- Noodzaak tot aanpassing grondgebruik vanwege klimaatverandering

- Verzilting en verslemping groeiend probleem

- Waterbeheer een grotere uitdaging als gevolg meer droge jaren en meer piekbelasting

- Grote gevolgen van de rechterlijke uitspraak inzake het Programma Aanpak Stikstof en de aanvullende wetgeving. 
SWOT-samenvatting subdoelstelling F Bijdragen aan de bescherming van de biodiversiteit, het versterken van ecosysteemdiensten en in stand houden van leefgebieden en landschappen

\begin{tabular}{|c|c|}
\hline Sterke punten & Zwakke punten \\
\hline $\begin{array}{l}\text { - Intensieve en efficiënte productiewijze vraagt minder } \\
\text { ruimte }\end{array}$ & $\begin{array}{l}\text { - Kassen worden uit oogpunt van landschappelijke } \\
\text { schoonheid als minder fraai bestempeld } \\
\text { - Invloed van kassen op biodiversiteit ('verglazing', } \\
\text { lichtuitstoot) }\end{array}$ \\
\hline Kansen & Bedreigingen \\
\hline
\end{tabular}

Het assenkruis van de definitieve SWOT voor subdoelstelling $f$ is nauwelijks relevant voor de snijbloementeelt, op een enkel hierboven genoemd punt na.

\section{Sterktes}

Intensieve productiewijze in kassen vraagt minder ruimtebeslag dan een extensieve productiewijze en biedt daardoor ruimte voor natuur en biodiversiteit.

\section{Zwaktes}

Snijbloemen worden voor een groot deel in kassen geteeld. Uit oogpunt van landschappelijke schoonheid worden kassen door de meeste mensen als minder fraai betiteld. Daarbij dragen kassen bij aan verschraling van de biodiversiteit.

\section{Kansen}

Door kassen zoveel mogelijk te concentreren in daarvoor aangemerkt gebieden beperkt men de landschappelijke effecten.

Het beperken van het aantal chemische gewasbeschermingsmiddelen zal de druk op de biodiversiteit doen afnemen.

\section{Bedreigingen}

Door de mogelijkheden voor plaatsen, waar nieuwbouw van kassen mag plaatsvinden, te beperken, wordt het landschap weliswaar zoveel mogelijk ontzien, maar krijgen snijbloemenbedrijven minder mogelijkheden zich te ontplooien. 


\subsection{Referenties}

Benninga, J., H. Barendse, Ch. Vermeulen, N. Garcia Victoria, M. Raaphorst, J. Hofland-Zijlstra (2015). Kwaliteitsplan roos. Wageningen UR, Rapport GTB-1336, Bleiswijk 2015

Benninga, J. (2004) Optimaal belichtingsniveau roos in relatie tot Glami-normen. LEI, project 64566, Den Haag

Berkhout, P., M. van Asseldonk, J. Benninga, L. G'e, R. Hoste, B. Smit (2015). De kracht van het agrocluster; Het belang van de primaire landbouwvoor het totale agrocomplex. LEI, Rapport 2015032, Den Haag

Bremmer, J., B. Janssens, M. Ruijs, J. Benninga, R. Stokkers, G. Splinter, P. Smit, L. Puister-Jansen (2019). Plantaardige ketens in beeld. Wageningen Economic Research, Den Haag

Meulen H.A.B. van der e.a., Agrimatie; https://www.wur. nl/nl/OnderzoekResultaten/Onderzoeksinstituten/Economic-Research/show-wecr/Inkomen-land-en-tuinbouwgedaald-in-coronajaar-2020.htm

PBL (Planbureau voor de Leefomgeving) (2019). Balans van de leefomgeving 2018. Den Haag 2019

Royal Flora Holland (2018). Bureau sierteelt, Landen analyse Nederland. Aalsmeer

Royal Flora Holland (2020). Jaarverslag 2019, Feiten en cijfers. Aalsmeer

Spoorenberg, P., D. Verstand, E. Beerling (2019). Tussenevaluatie van de nota gezonde groei duurzame oogst: deelproject economie / Rapportknelpunten. Wageningen Plant Research

Velden, N. van der, Smit, P. (2020). Energiemonitor van de Nederlandse glastuinbouw 2019. Wageningen Economic Research, Rapport 2020-109

Westerman, A.D., J. Benninga, R.L. van Uffelen, J. Nienhuis, C. Reijnders (2005). Lichtreductiescherm en fiscale stimulering; Onderbouwing aanvraag voor MIA en EIA. LEI, project 4018200, Den Haag

Zevenbergen, B. (eindredactie) (2021). Visie op sierteelt; Toekomstbestendig door transparantie over duurzaamheid. Publicatie ABN AMRO

https://www.bestrijdingsmiddelenatlas.nl/atlas/1/1

https://themasites.pbl.nl/balansvandeleefomgeving/jaargang-2018/themas/landbouw-envoedsel/gewasbeschermingsmiddelen-oppervlaktewater

https://www.agrimatie. nl/ThemaResultaat. aspx?SubpubID=2232\&themaID=2280\&indicatorID =2919\& sectorID $=2240$

FSI (2020). About - FSI 2020 


\subsection{Bijlage Indicatoren}

N.B. Alle data zijn op basis van Eurostat of nationale data als in Eurostaat geen gegevens beschikbaar waren op deelsectorniveau.

Indicatoren C.12 tot en met C.34

Tabel C.12 Aantal bedrijven naar bedrijfsgrootte in ha en standaardopbrengst (SO)

\begin{tabular}{lrrr} 
& \multicolumn{3}{c}{ Snijbloemenbedrijven } \\
\cline { 2 - 4 } Aantal bedrijven naar omvang in ha & 2010 & 2015 & 2020 \\
\hline$<1$ ha & & & \\
\hline $1-5$ ha & 492 & 348 & 266 \\
\hline $5-10$ ha & 819 & 538 & 478 \\
\hline $10-30$ ha & 109 & 100 & 92 \\
\hline $30-50$ ha & 60 & 50 & 63 \\
\hline$>50$ ha & 11 & 15 & 7 \\
\hline Totaal & 9 & 9 & 15 \\
\hline
\end{tabular}

Aantal bedrijven naar omvang in standaardopbrengst (SO)

\begin{tabular}{lrrr}
\hline SO: $3.000-25.000$ euro & 9 & 6 & 9 \\
\hline SO: $25.000-100.000$ euro & 87 & 76 & 43 \\
\hline SO: $100.000-250.000$ euro & 221 & 122 & 98 \\
\hline SO: $250.000-500.000$ euro & 319 & 240 & 183 \\
\hline SO: $500.000-1.000 .000$ euro & 365 & 234 & 182 \\
\hline SO: $1.000 .000-1.500 .000$ euro & 192 & 121 & 72 \\
\hline SO: $1.500 .000-3.000 .000$ euro & 225 & 169 & 150 \\
\hline SO: $>3.000 .000$ euro & 82 & 92 & 184 \\
\hline Totaal & 1.491 & 1.054 & 912 \\
\hline Gemiddelde bedrijfsgrootte in ha en SO & & & \\
\hline ha & 3,4 & 4,1 & 5,0 \\
\hline SO $(x 1.000$ euro) & 1.005 & 1.188 & 1.979 \\
idem $\mathbf{2 0 1 0}=\mathbf{1 0 0}$ & & & 123 \\
\hline ha & 100 & 118 & 149 \\
\hline SO $(x 1.000$ euro) & 100 & 197 \\
\hline
\end{tabular}

Tabel C.13a Arbeidsinzet - in arbeidsjaareenheden

\begin{tabular}{|c|c|c|c|}
\hline Snijbloemenbedrijven & 2010 & 2015 & 2020 \\
\hline \multirow[t]{2}{*}{ Arbeidsjaareenheden (regelmatig en onregelmatig) regulier werkzaam } & 7.495 & 5.117 & \multirow[t]{2}{*}{4.996} \\
\hline & 5.208 & 2.637 & \\
\hline Vrouw & 4.080 & 3.330 & 0 \\
\hline Niet-reguliere arbeidsinzet & 7.495 & 5.117 & 3.585 \\
\hline
\end{tabular}

Tabel C.13b Arbeidsinzet: aantal arbeidsjaareenheden naar gezinsarbeid en vreemde arbeid

\begin{tabular}{llll} 
Snijbloemenbedrijven & 2010 & 2015 & 2020 \\
gezin & 2.500 & 1.792 & 1.493 \\
\hline niet gezin & 9.075 & 6.655 & 7.745 \\
\hline
\end{tabular}


Tabel C.14 Leeftijdsopbouw agrarische bedrijfshoofden

\begin{tabular}{lrrr} 
Snijbloemenbedrijven & 2010 & 2015 & 2020 \\
$<40$ jaar (A) & 273 & 121 & 348 \\
\hline$>55$ jaar (B) & 438 & 378 \\
\hline Totaal & 1.500 & 1.060 & 921 \\
\hline ratio (A/B) & 62 & 35 \\
\hline
\end{tabular}

Tabel C.16 Bedrijfsopvolging

\begin{tabular}{lrr} 
Snijbloemenbedrijven & 2012 & 2016 \\
Aantal bedrijven met een opvolger & 130 & 73 \\
\hline aantal bedrijven met een bedrijfshoofd $>51$ jaar & 472 & 78 \\
\hline aantal bedrijven met een bedrijfshoofd $<51$ jaar & 586 & 314 \\
\hline aandeel bedrijven met een opvolger & 28 & 307 \\
\hline
\end{tabular}

Tabel C.17 Areaal snijbloemen (ha) op gespecialiseerde snijbloemenbedrijven

\begin{tabular}{lrrr} 
& 2010 & 2015 & 2020 \\
\hline Snijbloemenbedrijven, glas & 1.657 & 1.744 & 1.767 \\
\hline Snijbloemenbedrijven, open teelt & 196 & 173 & 361 \\
\hline
\end{tabular}

C18-C23: niet beschikbaar

Tabel C.24 Netto toegevoegde waarde per aje (in euro)

\begin{tabular}{lrrr} 
& 2010 & 2015 & 2019 \\
Snijbloemenbedrijven & 33.949 & 54.636 & 41.138 \\
\hline Index & 100 & 161 & 121
\end{tabular}

Tabel C.25 Inkomen uit bedrijf per oaje (in euro)

\begin{tabular}{|c|c|c|c|}
\hline & 2010 & 2015 & 2019 \\
\hline Snijbloemenbedrijven & 9.114 & 123.345 & 167.317 \\
\hline Index & 100 & 1.353 & 1.836 \\
\hline
\end{tabular}

C. 26 niet beschikbaar.

C.27 niet beschikbaar.

C.28 niet beschikbaar.

C.29 niet beschikbaar.

C.30 Handel.

Op het niveau van vollegrondsgroente zijn geen directe gegevens beschikbaar. De beschikbare handelsdata geven de in- en uitvoercijfers weer voor groenten totaal, de in- en uitvoer van glasgroenten is daarbij inbegrepen. Op basis van onderzoek uit 2017 (Bremmer et al., 2017) is duidelijk dat de export van vollegrondsgroenten in 2017 ruim $€ 11$ miljard bedroeg.

C.31 niet beschikbaar. 
Tabel C.32 Areaal biologische landbouw en aandeel areaal biologische landbouw op totale areaal vollegrondsgroente

\begin{tabular}{|c|c|c|c|c|c|c|}
\hline Aantal hectares & 2015 & 2016 & 2017 & 2018 & 2019 & 2020 \\
\hline Totaal areaal biologisch plus in omschakeling & 1.579 & 873 & 1.309 & 1.250 & 1.209 & 1.390 \\
\hline Areaal biologisch & 1.521 & 811 & 1.165 & 1.034 & 1.049 & 1.251 \\
\hline Totale areaal & 22.944 & 20.753 & 21.833 & 20.945 & 21.274 & 20.613 \\
\hline \multicolumn{7}{|l|}{ Aandeel (\%) } \\
\hline Areaal biologisch & 6,6 & 3,9 & 5,3 & 4,9 & 4,9 & 6,1 \\
\hline Areaal in omschakeling & 0,3 & 0,3 & 0,7 & 1,0 & 0,7 & 0,7 \\
\hline Totale areaal & 100 & 100 & 100 & 100 & 100 & 100 \\
\hline
\end{tabular}

Tabel C.33 Intensieve landbouw, aandeel areaal met een hoge inputintensiteit (grond met een totale input van veevoer, kunstmest en gewasbeschermingsmiddelen van meer dan €350 per ha)

\begin{tabular}{lrrr} 
Aandeel & 2010 & 2015 & 2019 \\
Vollegrondsgroentebedrijven & 30 & 63 & 70 \\
\hline
\end{tabular}

C.34 niet beschikbaar.

\section{Indicatoren C.35-C.48}

C.35 niet beschikbaar naar type bedrijf

C. 36 niet beschikbaar naar type bedrijf

C.38 niet beschikbaar naar type bedrijf

C. 40 niet beschikbaar naar type bedrijf

C.41 niet beschikbaar naar type bedrijf

C.42 niet beschikbaar naar type bedrijf

C.43 niet beschikbaar naar type bedrijf

C.44 niet beschikbaar naar type bedrijf

C. 45 niet beschikbaar naar type bedrijf

C.46 niet relevant voor de snijbloementeelt

C.47 niet relevant voor de snijbloementeelt

Tabel C.48 Afzet van pesticiden (1.000 ton werkzame stof)

\begin{tabular}{lrrr} 
& 2010 & 2015 & 2019 \\
Snijbloemenbedrijven & $\mathbf{0 , 1 7}$ & $\mathbf{0 , 1 6}$ & $\mathbf{0 , 1 5}$ \\
\hline
\end{tabular}




\section{SWOT-analyse deelsector Varkenshouderij}

Mariel Benus en Robert Hoste

N.B. deze analyse moet worden gelezen in samenhang met de SWOT-analyse op het niveau van de landbouw als geheel. Onderhavige analyse verbijzondert de SWOT-analyse waar nodig naar de deelsector in kwestie.

\subsection{Algemene beschrijving van de varkenshouderij}

De Nederlandse varkenshouderij

De Nederlandse varkenssector kende in 20203.553 bedrijven met varkens. Het aantal varkens in Nederland bedroeg 12,0 mln. in datzelfde jaar (CBS, 2020). Hiervan zijn er 871.000 zeugen die ieder circa 30 nakomelingen per jaar produceren. De invoer- en uitvoerhoeveelheid van levende varkens was 1,6 mln. en 11,3 mln. respectievelijk (RVO, 2021). In 2020 werden circa 15,8 mln. dieren binnenlands geslacht met een totaal gewicht van 1,58 mln. ton karkasgewicht (RVO, 2021). De meeste export van levende dieren en vlees gaat naar landen binnen de EU. Duitsland is een belangrijke bestemming, met $61 \%$ van de $7,0 \mathrm{mln}$. biggenexport en bijna $90 \%$ van de vleesvarkensexport van 1,3 $\mathrm{mln}$. dieren. Deze afzetmarkten fluctueren over de jaren qua afzetbestemmingen en volumes. Sinds 2016 is de export van varkensvlees en -producten vanuit de EU naar vooral China fors toegenomen onder invloed van een sterke vraag. Nederland exporteert varkensvlees naar meer dan 100 landen in de wereld, waaronder ook specifieke producten naar specifiek markten zoals hammen naar Italië of buiken naar Korea. Naast deze grote hoeveelheid export is er in veel mindere mate ook import van vlees uit buurlanden, met name Duitsland en België. Hoewel het aantal Nederlandse bedrijven de laatste decennia sterk afneemt, is het aantal dieren nauwelijks gedaald. Circa $30 \%$ van de geproduceerde varkens wordt geëxporteerd.

De varkenshouderij is sterk geconcentreerd in Oost-Brabant en Noord-Limburg. Daarnaast zijn er kleinere concentraties in Overijssel, Oost Gelderland, de Gelderse Vallei en Westelijk Brabant. Van oudsher werden op veel landbouwbedrijven enkele varkens gehouden, vooral om restanten van oogsten en andere producten tot waarde te brengen. Vanaf midden vorige eeuw werden gemengde bedrijven vaak te klein om werk te verschaffen aan meerdere kinderen/bedrijfsopvolgers. Mede door de schaarste aan cultuurgrond werd gezocht naar intensievere bedrijfstakken waarvoor weinig of geen grond nodig is. Ook dankzij de beschikbaarheid van goedkope veevoergrondstoffen, groeide de varkenshouderij uit tot een belangrijke bedrijfstak. Verdere specialisatie en schaalvergroting zorgde voor een professionele varkenssector, ondersteund door eveneens groeiende bedrijven voor toelevering en verwerking van producten en diensten.

Het aantal bedrijven neemt jaarlijks af, terwijl de bedrijfsgrootte navenant toeneemt. Dit geldt voor zowel zeugenbedrijven als de vleesvarkensbedrijven. Elke tien jaar halveert het aantal bedrijven, terwijl het totale aantal varkens al jarenlang schommelt rondom hetzelfde aantal (www.agrimatie.nl, 2020). 
Aantal bedrijven, aantal dieren en dieren per bedrijf

varkens

16.000

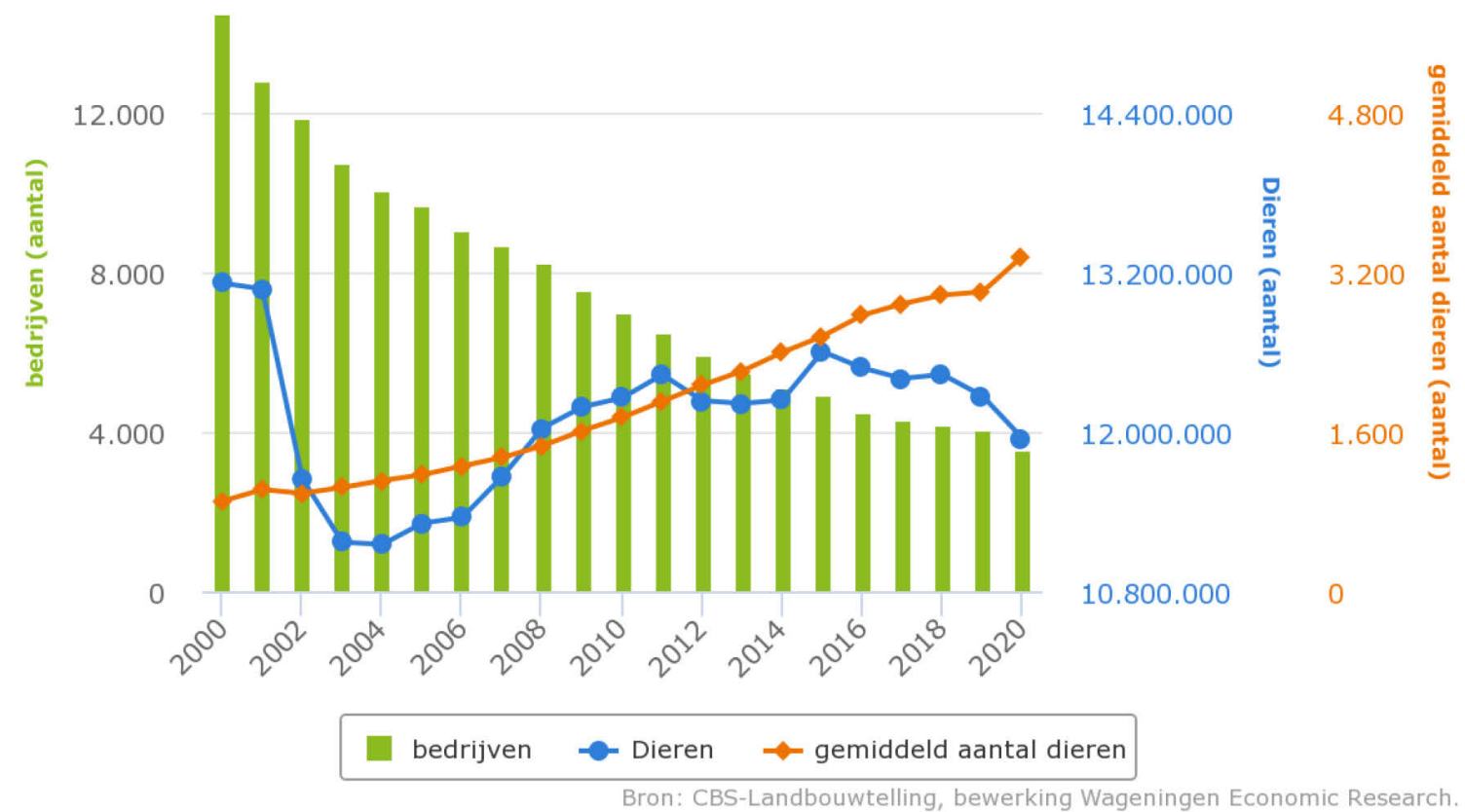

Figuur 1 Aantal bedrijven en aantal dieren en dieren per bedrijf in Nederland (cijfers kunnen afwijken van cijfers in bijlage omdat in bijlage enkel gespecialiseerde varkensbedrijven zijn meegenomen)

\section{Productiesysteem}

Het productiesysteem van de Nederlandse varkenshouderij bestaat uit meerdere schakels: fokkerij, vermeerdering en vleesvarkenshouderij die nauw met elkaar in verbinding staan. Fokzeugenbedrijven leveren de zeugen aan vermeerderingsbedrijven en vermeerderingsbedrijven leveren de geboren en opgefokte biggen aan vleesvarkensbedrijven die de biggen laten groeien tot vleesvarkens. Het productieproces kan uit verschillende veehouders bestaan die ieder een schakel in het proces hebben combinaties van schakels komen ook voor; dit zijn vooral de zogenaamde 'gesloten bedrijven' met vermeerderingszeugen en vleesvarkens. Naast het gangbare productiesysteem zijn er ook allerlei systemen die een extra plus toevoegen op het gangbare houderijsysteem. Denk bijvoorbeeld aan het beter leven keurmerk, of de biologische varkenshouderij die onder andere extra ruimte biedt aan de dieren in het houderijsysteem. Ook sterk geïntegreerde kwaliteitssystemen en diverse concepten zijn doorgedrongen tot het Nederlandse varkenshouderij systeem. Investering en ontwikkeling van moderne productiesystemen heeft de Nederlandse varkenshouderij technisch naar de koploperspositie op wereldniveau geholpen (van Ferneij, 2018).

Gespecialiseerde zeugenbedrijven in Nederland hebben in 2020 gemiddeld 790 zeugen; gespecialiseerde vleesvarkensbedrijven hebben gemiddeld 2.500 vleesvarkens. Gesloten varkensbedrijven hebben 2.700 vleesvarkens en 490 zeugen per bedrijf (CBS, 2021). Voor wat betreft schaalgrootte is de Nederlandse varkenshouderij een middenmoter in Europa (www.agrimatie.nl, 2020).

\section{Aandeel biologisch}

De biologische varkenshouderij in Nederland is een marktniche, met in het jaar 2020103.000 biologische varkens, 0,7\% van de Nederlandse varkensstapel. In Nederland zijn er 187 bedrijven met biologische varkens, 5,3\% van het aantal bedrijven met varkens in Nederland. Het aantal varkens is sinds 2011 met ongeveer $80 \%$ gestegen; het aantal bedrijven steeg in dezelfde periode met circa $90 \%$. Het aantal biologisch gehouden varkens in Nederland vanaf 2011 tot en met 2020 wordt weergegeven in figuur 1 . 
Er zijn diverse afnemers van varkens; de grootste is De Groene Weg, onderdeel van Vion Food Group. Een belangrijk deel (circa 60\%) van de productie van biologisch varkensvlees wordt geëxporteerd, vooral naar Duitsland en het Verenigd Koninkrijk (www.agrimatie.nl).

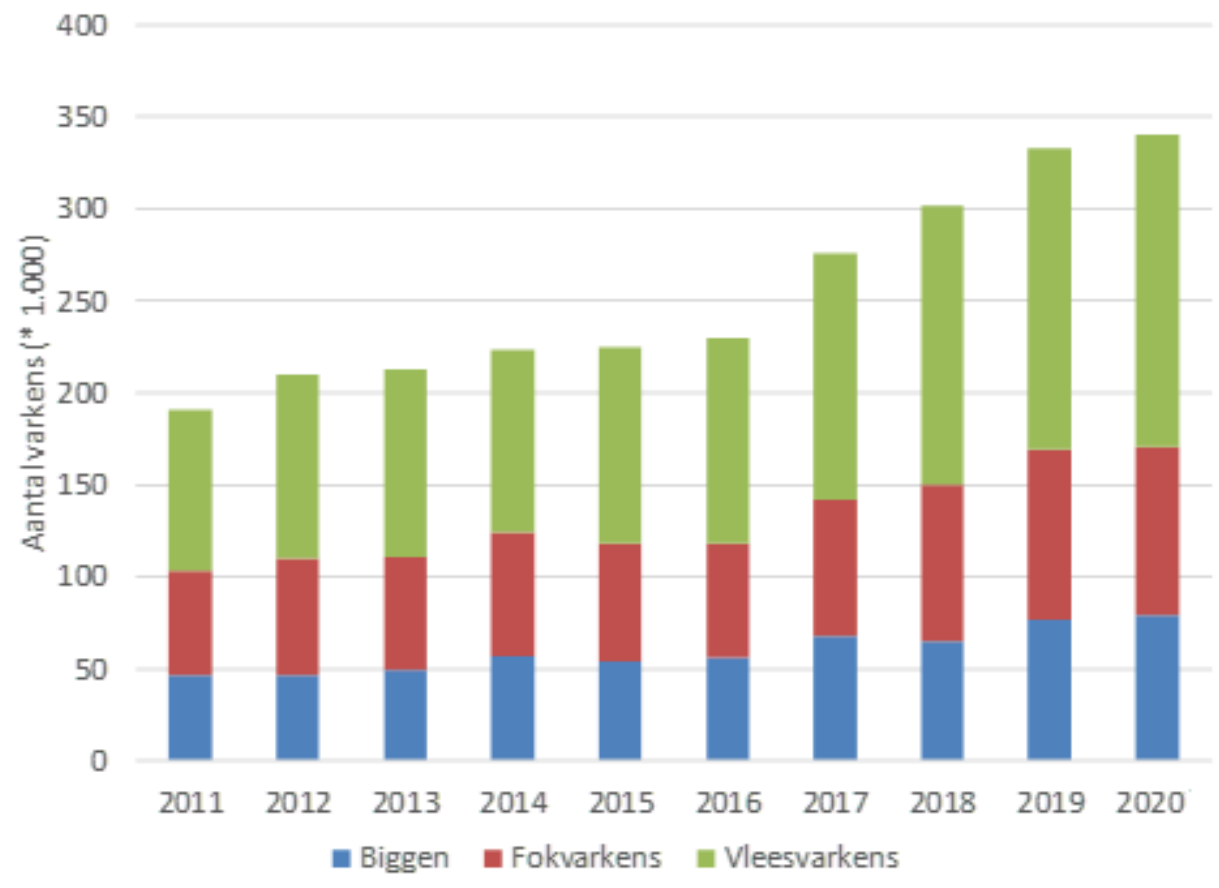

Figuur 2 Aantal biologisch gehouden varkens in Nederland van 2011 tot en met 2020 Bron: CBS.

Bedrijfsgrootte, opvolging, inkomen

Evenals in de overige sectoren van de landbouw is het aantal bedrijven met varkens ook gedaald. De omvang van de Nederlandse varkensstapel schommelt al jaren rondom hetzelfde aantal varkens. De varkens staan evenwel op steeds minder bedrijven. Het aantal bedrijven met varkens is afgenomen van 14,5 duizend in 2000 tot 3,6 duizend in 2020 (CBS, 2020). Het gemiddeld aantal varkens per bedrijf nam toe van 900 in 2000 naar 3.400 in 2020. De daling van het aantal varkensbedrijven hangt vooral samen met beperkt economisch perspectief en gebrek aan opvolging. Hierbij speelt ook de druk van maatschappelijke eisen aan de houderij, waaronder beperking van de ammoniakemissie, dierenwelzijn, mestafzet enz. In 2019 is de Subsidieregeling sanering varkenshouderij (Srv) opengesteld, waaraan varkensbedrijven in concentratiegebieden met sprake van een geuroverlast aan mee konden doen (www.agrimatie.nl, 2020).

De netto toegevoegde waarde tegen factorkosten (C.24), de beloning voor de inzet van de productiefactoren arbeid, vee, grond en kapitaal varieert in de intensieve sectoren gemiddeld meer dan in andere sectoren van de land- en tuinbouw. Opbrengstprijzen van vleesvarkens en biggen schommelen sterk, evenals prijzen van inputs (vooral veevoer). Bovendien vormen de kosten van eigen arbeid een relatief gering deel van de omzet, waardoor prijsschommelingen al snel resulteren in een flinke fluctuatie van het arbeidsinkomen. Deze arbeidsinkomens fluctueren sterker dan in de akkerbouw en de melkveehouderij. Waar de inkomens in de varkenshouderij structureel gemiddeld niet erg hoog liggen (gemiddeld $€ 27.700$ per onbetaalde arbeidsjaareenheid (oaje) over de jaren 2001-2018) lag dit in 2019 op een bijzonder hoog niveau. Door substantiële uitbraken van Afrikaanse varkenspest in vooral China lag de wereldmarktprijs in de periode april 2019-april 2020 op een hoog niveau. Het gemiddelde gerealiseerde inkomen in dat jaar lag op $€ 283.400$ per oaje. Gezien het cyclische patroon van gunstige en ongunstige prijzen is de verwachting dat de inkomens de komende paar jaar op een laag niveau zullen liggen (www.agrimatie.nl, 2020). 
Netto toegevoegde waarde en werkgelegenheid

Er zijn geen gegevens beschikbaar over de bijdrage van de varkenshouderij aan de netto toegevoegd waarde en de werkgelegenheid. Deze zijn er wel voor het intensieve veehouderijcomplex, waarvan de varkenshouderij onderdeel is.

Het intensieve veehouderijcomplex is opgebouwd uit de vleeskalveren-, de varkens-, de legpluimveeen de vleeskuikenbedrijven (totaal 5.900 bedrijven in 2018) en de bij deze sectoren horende slachterijen en vleesverwerkers. Daarnaast maken ook toeleveranciers (waaronder de veevoederindustrie) en distributiebedrijven deel uit van dit complex, voor het deel dat zij leveren aan de primaire intensieve veehouderijbedrijven of de verwerkende industrieën.

De toegevoegde waarde van het intensieve veehouderijcomplex bedroeg $€ 7 \mathrm{mld}$. in 2018 - het meest recente jaar waarvoor de cijfers beschikbaar zijn. Dit was gelijk aan 2017. De toegevoegde waarde van dit complex, in 2018 circa 0,9\% van het bruto binnenlands product (bbp), hangt volledig samen met de verwerking van binnenlandse agrarische grondstoffen (dieren): de import van agrarische grondstoffen door de slachterijen van varkens, pluimvee en vleeskalveren is vrijwel nihil. Circa $46 \%$ van de toegevoegde waarde van het intensieve veehouderijcomplex kwam tot stand in de toelevering. De verwerkende industrie en de distributiebedrijven leverden een bijdrage van respectievelijk $30 \%$ en $14 \%$ aan de toegevoegde waarde. Met een aandeel van circa $10 \%$ in 2018 was de bijdrage van de primaire bedrijven in het cluster beperkt. Dit was het gevolg van slechte prijzen voor varkens door een groter aanbod in de EU, in combinatie met moeizamere export naar China. In 2019 zijn de varkensprijzen overigens enorm aangetrokken door de problemen met Afrikaanse varkenspest in China en grote vraaguitval met toename van de export.

De totale werkgelegenheid van het intensieve veehouderijcomplex kwam in 2018 uit op ruim 92.000 arbeidsjaren. Ongeveer $17 \%$ van de werkgelegenheid in dit complex zit op de primaire bedrijven. Dit is ruim anderhalf keer zoveel als de bijdrage aan de toegevoegde waarde, wat duidt op een relatief lage toegevoegde waarde per arbeidskracht op de primaire bedrijven in vergelijking met de overige schakels in het complex. De toelevering neemt in het complex $43 \%$ van de werkgelegenheid voor rekening, de verwerkende industrie bijna $30 \%$ en de distributie $11 \%$. Sinds 2010 is de werkgelegenheid - relatief gezien - het meest toegenomen in de verwerkende industrie binnen het complex (www.agrimatie.nl, 2020). Wat de totale werkgelegenheid van de biologische varkenshouderij is moeilijk te zeggen. In Nederland is maar $0,7 \%$ van het totaal gehouden varkens biologisch. Dit zijn 187 bedrijven. De biologische varkenshouderij is wel arbeidsintensiever, er wordt meer werk verzet en het werk is ook relatief zwaarder, mede daardoor zijn biologische bedrijven vaak kleiner.

\section{Bedrijfsovername}

In de Landbouwtelling wordt eens in de vier jaar gevraagd of er een bedrijfsopvolger aanwezig is. Deze vraag wordt gesteld aan bedrijfshoofden van 50 jaar of ouder met een bedrijf zonder rechtspersoonlijkheid, zoals een eenmanszaak, maatschap, commanditaire vennootschap of vennootschap onder firma. Bij een bedrijfsvoering die uit meerdere personen bestaat, wordt gevraagd naar de leeftijd van het bedrijfshoofd met de grootste zakelijke en bedrijfsmatige verantwoordelijkheid in het bedrijf. Als de bedrijfshoofden evenveel verantwoordelijkheid hebben, dan wordt gevraagd naar de leeftijd van de oudste ondernemer.

In 2020 telde Nederland 1.071 varkensbedrijven met een bedrijfshoofd van minstens 50 jaar, waarvan 432 bedrijven bedrijfsopvolging hebben en het merendeel van de bedrijven ( 639 bedrijven) niet. Het percentage bedrijven zonder bedrijfsopvolger ligt al jaren rond 60-70\%. Van bedrijven die niet worden overgenomen, gaat de grond veelal naar de overblijvende bedrijven, die daarmee hun schaal kunnen vergroten (CBS, 2020).

\section{Handel}

Over de handel in varkensvlees is niet direct informatie voorhanden, wel over de handel in vlees totaal. Nederland exporteerde in 2020 voor $€$ 8,7 miljard aan vlees en eetbare slachtbijproducten, bijna 3\% minder dan in 2019. De import nam met 7\% af, vooral uit Duitsland en België kwam minder vlees ons land binnen. Voor de vleesindustrie was het een bewogen jaar. Door corona-uitbraken 
moesten meerdere keren slachterijen in zowel Nederland, Duitsland en Denemarken tijdelijk stil worden gelegd. De sluiting van restaurants in belangrijke afzetgebieden leidde tot een sterke vraaguitval naar bepaalde types vlees, zoals kalfsvlees. Door de uitbraak van Afrikaanse varkenspest in China in 2019 en omringende landen, is evenals in 2019 ook in 2020 de exportwaarde naar die landen sterk gestegen. Ondanks deze sterke waardegroei, loopt dit jaar de exportgroei elke maand een beetje terug. Ook is er sterke prijsdruk omdat Duits varkensvlees vanaf september 2020 niet naar China mag vanwege varkenspest bij wilde zwijnen in Duitsland. Het Duitse varkensvlees komt hierdoor ook op de Europese markt. Over de ontwikkelingen in het varkensvlees wordt in hoofdstuk 9 uitgeweid. De exportwaarde van kippenvlees is dit jaar ook lager, het sluiten van de restaurants en het out-of-home-segment (zoals bedrijfs- en schoolkantines, catering) raakt ook deze branche behoorlijk. Met name de afzet naar de Engelse markt, waar men veel (grill)kippen en filets afneemt uit Nederland, is slecht. Omdat Pools kippenvlees China niet in mag vanwege vogelgriep, komt er ook veel kippenvlees op de Europese markt. ${ }^{28}$ Dit zit de export, met name de Nederlandse export naar het VK in de weg. Per saldo leidde dit tot een lagere exportwaarde van ruim $3 \%$.

Van al het vlees ging 20\% naar Duitsland en $12 \%$ naar het VK, $2 \%$ minder dan in 2019 . Het aandeel van de export naar China steeg sterk, van $8 \%$ naar $11 \%$ in 2020 (Jukema et al, 2021).

28 https://www. pluimveeweb.nl/artikel/238584-vogelgriep-en-afrikaanse-varkenspest-raken-nederlandse-vleeskuikensectorniet-zoals-we-graag-zouden-zien/ 


\subsection{SWOT-analyse per specifieke doelstelling}

\section{(a) Bieden van steun met het oog op een leefbaar landbouwinkomen en veerkracht in de hele Unie om de voedselzekerheid te vergroten;}

SWOT-samenvatting subdoelstelling A Bieden van steun met het oog op een leefbaar landbouwinkomen en veerkracht in de hele Europese Unie om de voedselzekerheid te vergroten

$\begin{array}{ll}\text { Sterke punten } & \text { Zwakke punten } \\ \text { - Productieomstandigheden, infrastructuur } & \text { - Hoge kostprijs t.o.v. andere landen als gevolg van dure } \\ \text { - Opleidingsniveau, kennisnetwerk } & \text { grond, arbeid en mestafzet } \\ \text { - Innovatief vermogen } & \text { - Inkomens landbouw lager ten opzichte van vergelijkbaar } \\ \text { - Gezinsbedrijven met veerkracht } & \text { werk buiten de landbouw } \\ \text { - Hoge productiviteit (vooral in de zeugenhouderij) } & \text { - Werken buiten de landbouw is financieel aantrekkelijker } \\ \text { - Productiesystemen met oog op dierenwelzijn, toekomst en } & \text { - De onderhandelingspositie van primaire bedrijven in de } \\ \text { milieu (internationaal gezien) } & \text { keten is zwak } \\ \text { - Goede financieringsinfrastructur (in Nederland) voor } & \text { - Samenwerking binnen de keten moet beter } \\ \text { ondernemers die willen blijven investeren } & \text { - Er is een beperkte beschikbaarheid van arbeidskrachten in } \\ \text { - Goed georganiseerde biologische varkensketen die door } & \text { zowel slachterijen als op primaire varkensbedrijven. De } \\ \text { mogelijk toenemende EU vraag groeit } & \text { afhankelijk van arbeidskrachten elders uit de EU is groot } \\ & \text { - Sterke vermogensbehoefte bemoeilijkt bedrijfsovernames } \\ & \text { - Rendement op eigen vermogen en arbeid lager dan in } \\ & \text { sectoren buiten de landbouw } \\ \text { - Regelgeving (milieu) en productierechten belemmeren } & \text { extensivering } \\ \text { - Er is angst bij ondernemers om te investeren door lage } & \text { inkomens en politieke onrust } \\ \text { - Sterke afhankelijkheid van internationale } \\ \text { markten/handelsstromen }\end{array}$

- Markt voor nieuwe bedrijfsvormen/verdienmodellen (biologisch, korte ketens, multifunctionele landbouw) toegevoegde waarde producten

- Sterke verstedelijking van het Nederlandse platteland geeft kansen voor directe verbindingen met de stad via het leveren van producten en diensten

- Aandacht voor het vergroten van veerkracht

- NL varkensvlees scoort goed ten opzichte van andere landen op onderscheidenheid en toegevoegde waarde (dierenwelzijn, laag antibioticagebruik) naast productveiligheid garanties
Bedreigingen

- Bedrijfsovername niet eenvoudig door de kapitaalintensiteit van bedrijven

- Na bedrijfsovername is het aantrekken van vreemd vermogen lastig door zware financiering

- Hoge grondprijs en arbeid belemmeren extensivering

- Aantrekkingskracht werk buiten de sector, jonge boeren kiezen bewust voor baan buiten de landbouw

(is deels ook een kans omdat het ruimte schept voor andere bedrijven om door te groeien)

- Ongelijk speelveld; markt neemt producten af uit buitenland die onder andere - veelal lagere - eisen zijn geproduceerd

- Bedrijven die goed personeel nodig hebben komen in de knel door een arbeiderstekort

- Vleesconsumptie zal op de lange termijn (in ieder geval in Europa) mogelijk (fors) afnemen (eiwittransitie)

\section{Sterktes}

\section{Gezinsbedrijven met veerkracht}

In Nederland zijn de meeste land- en tuinbouwbedrijven (waaronder ook varkensbedrijven) een traditioneel gezinsbedrijf. Bij traditionele gezinsbedrijven wordt de arbeid verricht door de ondernemer, eventueel meewerkende gezinsleden en enkele medewerkers. Het bedrijf is deels gefinancierd met het eigen vermogen van de ondernemer en zijn gezin, maar vreemd vermogen is onmisbaar, zeker bij schaalsprongen. De veerkracht van het bedrijf zit hem erin dat dit bedrijven zijn waarbij het gezin en het bedrijf nauw met elkaar verbonden zijn, schommelingen in inkomens worden vooral opgevangen vanuit het eigen vermogen, arbeidspieken worden flexibel ingevuld en beslissingen worden aan de keukentafel genomen. Zo kan er snel gereageerd worden bij onverwachte situaties. 
Hoge productiviteit (in de zeugenhouderij)

De varkenssector in Nederland kenmerkt zich door een hoge productiviteit. Na Denemarken staat de Nederlandse varkenssector qua zeugenproductiviteit aan de top in de wereld en is voor een groot deel (ongeveer 30\%) afhankelijk van de export van biggen. In de vleesvarkenshouderij is de productiviteit en rentabiliteit vergelijkbaar met veel andere Europese landen. De voederefficiëntie is wel beduidend beter dan in andere landen, onder andere door geconcentreerd voer, maar ook een gunstig slachtgewicht en het stoppen met castreren (www.agrimatie.nl, 2020).

Niet van toepassing:

- Hoge aandeel berekende kosten vergroot weerbaarheid.

\section{Zwaktes}

Hoge kostprijs t.o.v. niet- EU landen als gevolg van dure grond, arbeid en mestafzet De vleesvarkenshouderij in Nederland heeft hogere productiekosten dan in omringende landen. Dit komt door een combinatie van iets hogere voerkosten, duurdere huisvestings- en arbeidskosten, productierechten en mestafzetkosten. De belangrijkste landen met een professionele varkensproductie in West-Europa hebben een berekende kostprijs van circa $€ 1,40-1,50$ per kg slachtgewicht. Nederland en Duitsland zijn duidelijk duurder met een kostprijs van $€$ 1,57 per kg in 2019 (bron? Interpig cijfers 2019?)

Het is vooral in de vleesvarkenshouderij waar veel Nederlandse bedrijven in het nadeel zijn. De spreiding in kostprijs tussen bedrijven is zeer groot. Een analyse van enkele jaren geleden laat een bandbreedte zien in kostprijs op gespecialiseerde vleesvarkensbedrijven in Nederland van 26 eurocent per kg karkas. Belangrijke verschillen tussen vleesvarkensbedrijven zijn te vinden in voer- en arbeidskosten (InterPIG, 2018)

\section{Vermogensbehoefte}

De vermogensbehoefte is ook voor varkensbedrijven een obstakel bij overname. De stallen, dieren en grond vormen bij elkaar ook een fors kaptiaal; bijna $€ 3 \mathrm{mln}$. in 2019 . Het grootste knelpunt is echter de lage rentabiliteit afgezet tegen de investeringsbehoefte (stal, rechten, dieren, soms wat grond). Daarnaast is er een lage beschikbaarheid van opvolgers.

\section{Kansen}

Markt voor nieuwe bedrijfsvormen/verdienmodellen (biologisch, korte ketens, multifunctionele landbouw)

Door maatschappelijke druk een verhoogde kostprijs en een afzet op de wereldmarkt wordt er door veel boeren gekeken naar andere verdienmodellen. Hier kan men denken aan biologische varkenshouderij, diverse keurmerken (zoals onder andere Het Beter Leven Keurmerk), korte ketens of het hebben van een tweede tak (multifunctionele landbouw). Door meer bewustwording van de consument in het binnen en buitenland groeit bijvoorbeeld de biologische varkenshouderij gestaag met zo'n 6 à 7\% per jaar. Ook het aandeel varkensvlees dat in concepten wordt afgezet groeit gestaag (Logatcheva 2019).

Niet van toepassing

- Vraag naar publieke diensten (nieuw GLB)

- Inzet Platform Multifunctionele Landbouw om knelpunten in ontwikkeling multifunctionele landbouw weg te nemen en ontwikkelruimte te creëren

- Subsidiemodule agrarische bedrijfsadvisering en educatie (SABE-regeling).

Het leveren van publieke diensten en multifunctionele landbouw spelen niet tot nauwelijks een rol in de varkenshouderij. 


\section{Bedreigingen}

Vleesconsumptie zal op de lange termijn (in ieder geval in Europa) mogelijk (fors) afnemen (eiwittransitie).

De mate van vleesconsumptie blijkt onder andere samen te hangen met het inkomensniveau. Hierbij neemt de consumptie toe met stijgend inkomen, tot een bepaald verzadigingsniveau, waarna de vleesconsumptie iets afneemt. In West-Europa daalt de komende decennia naar verwachting de vleesconsumptie. Door de verminderde consumptie veranderd ook de vraag van veel varkensvlees naar goed varkensvlees. Met een groeiende wereldbevolking en stijging van de welvaart is de verwachting dat de vraag naar vlees en zuivel de komende decennia wereldwijd sterk zal toenemen. De verwachting is dat varkensvlees voornamelijk meer in Aziatische landen zal worden geconsumeerd.

Niet van toepassing

- Inkomensondersteunende en stabiliserende werking toeslagen neemt verder af.

De GLB-toeslagen zijn voor de varkenshouderij niet relevant. 
(b) Vergroten van de marktgerichtheid en van het concurrentievermogen, onder meer door beter te focussen op onderzoek, technologie en digitalisering;

SWOT-samenvatting subdoelstelling B - Vergroten van de marktgerichtheid en van het concurrentievermogen, onder meer door beter te focussen op onderzoek, technologie en digitalisering

\begin{tabular}{|c|c|}
\hline Sterke punten & Zwakke punten \\
\hline $\begin{array}{l}\text { - Goede uitgangspositie logistiek, infrastructuur, organisatie } \\
\text { - Handelspositie van Nederlandse varkenshouderij is } \\
\text { omvangrijk } \\
\text { - Beleid Topsectoren versterkt ook de innovatiekracht in de } \\
\text { Nederlandse varkenshouderij door maatschappelijke } \\
\text { uitdagingen op te lossen, en te investeren in onderzoek } \\
\text { en innovatie } \\
\text { - Organisatievermogen, samenwerking en innovatiekracht } \\
\text { sector/Goede samenwerking van toeleverende bedrijven } \\
\text { (Internationale sterke bedrijven) }\end{array}$ & $\begin{array}{l}\text { - Vanuit maatschappelijk oogpunt weerstand tegen } \\
\text { - Medicijnen (en indirect bestrijdingsmiddelen) } \\
\text { intensiteit } \\
\text { - Wet van de remmende voorsprong: toenemende druk } \\
\text { afgelopen jaren op concurrentiepositie } \\
\text { - Hoge wet- en regelgevingsdruk, deels bovenwettelijk, met } \\
\text { nauwelijks verwaarding van de extra kosten } \\
\text { - Hoge financieringslasten beperken } \\
\text { ontwikkelingsmogelijkheden (met name middengroep) }\end{array}$ \\
\hline
\end{tabular}

\section{Sterktes}

Goede samenwerking van toeleverende bedrijven (Internationale sterke bedrijven) Vanwege de uiteenlopende vraag uit Nederland, EU en de wereld is het zaak dat de Nederlandse varkenshouderijsector steeds inspeelt op de markteisen door specifieke Product Markt Combinaties. Afnemers stellen namelijk steeds hogere eisen en willen weten waar en hoe het product geproduceerd is. In Nederland is het goed gesteld met de samenwerking tussen primaire bedrijven en de toeleverende bedrijven (Denk hierbij aan bedrijven die diensten en goederen leveren zoals klimaatspecialisten, mengvoerbedrijven, leveranciers van stalsystemen en farmaceuten etc.). Door goed ondernemerschap, vakmanschap en strenger worden van wet en regelgeving en eisen vanuit de markt, wordt innovatie in samenwerking met deze bedrijven telkens tot een hoger niveau gebracht. Doordat Nederland nog altijd moet produceren voor een wereldmarkt worden ondernemers innovatief in het bedenken van essentiële oplossingen om de kostprijs zo ver mogelijk te drukken.

Niet van toepassing

- Sterke Groei R\&D agribusiness (geen gegevens over)

\section{Zwaktes}

Vanuit maatschappelijk oogpunt weerstand op medicijnen (en indirect bestrijdingsmiddelen)/Maatschappelijke weerstand op grootschaligheid en intensiteit. De maatschappelijke acceptatie van de varkenshouderij neemt af. De Nederlandse samenleving eist meer aandacht voor dierwelzijn, gezondheid en zoönosen (mens en dier), hinder- en emissieverlaging (geur-, fijnstof en milieubelasting) en transparantie. Een eerste actiepunt is het aandragen van een 
oplossing voor de geuroverlast, fijnstof en het mineralenoverschot (mest). Ten tweede moet het vertrouwen in de varkenshouderij hersteld worden door meer transparantie in de vorm van concepten, ketensamenwerking en communicatie. Zoals bijvoorbeeld het laten zien van vlees bij de slagerij en de herkomst hiervan. Bestaande ketenkwaliteitsystemen werken als een zelfregulerend systeem, waarbij individuele bedrijven die gedragscodes niet respecteren door het collectief worden gecorrigeerd. Dit is dan een verantwoordelijkheid voor de gehele keten.

Slaagt de keten er niet of onvoldoende in om de kloof te dichten, dan is er grote kans op verscherpte wet- en regelgeving en op krimp van de sector. Zonder ontwikkelruimte zal de varkenshouderij in Nederland verder krimpen, met grote gevolgen voor de gehele productieketen (van Ferneij, 2018).

Hoge financieringslasten beperken ontwikkelingsmogelijkheden (met name middengroep).

Door de hoge financieringslasten die varkenshouders dragen (ten opzichte van de opbrengsten die zij halen) is er minder geld beschikbaar voor (extra) investeringen, niet alleen kan de varkenshouder zijn bedrijf niet door ontwikkelen, ook gaat dit om financiering voor toekomstbestendigere/duurzame investeringen.

\section{Kansen}

Vraag naar bedrijfssystemen met minder externe effecten (kringlopen)

Hoewel de varkenssector al een substantiële hoeveelheid restproducten verwerkt en tot waarde brengt, worden er ook grondstoffen vervoederd die ook humaan bruikbaar zouden zijn. Een toename van circulaire systemen is vanuit dit oogpunt een kans. Dit zou de langeafstandstransport van voergrondstoffen beperken.

Meer aandacht voor andere vormen van landbouw dan de klassieke op kostprijsverlaging gerichte modellen

Bij toenemende eisen aan de bedrijfsvoering heeft er een sterke efficiëntieslag plaatsgevonden, zowel qua dierproductie als voerefficiëntie. Kostprijsverlaging is echter een eindige oplossingsrichting en nieuwe kansen moeten gezocht worden in producten die met meerwaarde verkocht kunnen worden aan de consument. Onderscheid op gebied van consumptiekwaliteit (merk, beleving, smaak, gezondheid, bereidingsgemak enz.) en productieomstandigheden (dierenwelzijn, milieubescherming enz.) is te vinden in een scala aan marktconcepten. Dit is echter nog steeds geen structurele keuze voor een meerwaardebenadering, aangezien deze concepten in de regel niet verder gaan dan het vergoeden van de meerkosten. Een transitie naar wat lagere vleesconsumptie van onderscheidende kwaliteit is een antwoord op de ratrace naar lage kostprijs; het is wel zaak de consument hierin mee te nemen. Dit kan bijvoorbeeld gedaan worden door campagnes. Een voorbeeld hiervan is de campagne van MilieuCentraal voor de top-10 keurmerken.

\section{Technologie}

Een duidelijke kans voor de toekomst is onderzoek, innovatie en investering op het gebied van technologie en digitalisering. Dit zou kunnen bijdragen aan een transparantere en toekomstbestendigere varkensketen door bijvoorbeeld een digitaal informatiesysteem, dierenpaspoorten en de doorrekening van de $\mathrm{CO}_{2}$ footprint die kan worden gemeten op basis van data van herkomst/veevoedergebruik etc. Deze technologische oplossingen kunnen garant staan voor ketenoptimalisatie waarbij elke schakel vloeiend in de andere schakel overloopt waardoor extra marge wordt gerealiseerd. Door technologie kan er specifiek worden gekeken naar de afnemerswensen van de markt, hierop kan worden ingespeeld waardoor er een groter/meer gespecialiseerder productportfolio kan worden gecreëerd, dit biedt kansen op andere markten die specifieke eisen hebben. Als laatste kan technologie een oplossing bieden voor een early warning systeem ter preventie van infectieziekten wat kan resulteren in een vermindering van medicijngebruik per dier.

Niet van toepassing

- Stimuleren natuurinclusieve landbouw, zoals Green Deal Natuurincl. Landbouw. 


\section{Kans/Bedreiging}

Bereidheid consumenten te betalen voor een duurzame plus vooralsnog beperkt.

Vlees dient gepositioneerd te worden als waardevol product, vleesreclames dienen beperkt te zijn en vlees moet niet langer de rol hebben van klantentrekker op het argument 'goedkoop'. Ngo's kunnen hierin een rol spelen. Het belasten van vlees kan het bewustzijn van consumenten verbeteren. 


\section{(c) Verbeteren van de positie van de landbouwers in de waardeketen;}

SWOT-samenvatting subdoelstelling C Verbeteren van de positie van de landbouwers in de waardeketen

\begin{tabular}{|c|c|}
\hline Sterke punten & Zwakke punten \\
\hline $\begin{array}{l}\text { - Uitgebreid kennisnetwerk dat kan bijdragen aan het } \\
\text { - Oniveau van kennis en innovatie } \\
\text { ondernemers met goed ondernemerschap en een } \\
\text { - Sterk innovatief vermogen van ondernemers } \\
\text { - Dichtbij afzetmarkt -als men levert in concepten. } \\
\text { (varken van morgen zorgt ervoor dat de Nederlandse } \\
\text { retailers producten afneemt van Nederlandse boeren) } \\
\text { - Markten die verder van huis liggen richten zich op een } \\
\text { goede vierkantsverwaarding } \\
\text { - Goede exportpositie naar 3e landen }\end{array}$ & $\begin{array}{l}\text { - Onderhandelingspositie in de keten } \\
\text { - Beperkt aandeel in consumenteneuro } \\
\text { - Samenwerking tussen primaire agrarische bedrijven moet } \\
\text { beter (bijvoorbeeld door gezamenlijke verkoop/oude } \\
\text { coöperatiestructuur) } \\
\text { - Er is een sterke focus op kostprijsverlaging omdat de } \\
\text { Nederlandse varkenshouder (in gangbaar concept) moet } \\
\text { concurreren met andere landen }\end{array}$ \\
\hline
\end{tabular}

\section{Sterktes}

Goed ondernemerschap/ondernemerschapsmentaliteit.

De gemiddelde Nederlandse agrarisch ondernemer toont goed ondernemerschap. Ook Nederlandse varkenshouders zijn bereid om te investeren en bedrijfsrisico's te nemen, ondanks een matig inkomen.

Bedrijven in de Nederlandse varkenshouderijketen zijn internationaal toonaangevend en investeren volop in vernieuwing en verduurzaming. In 2017 zijn de investeringen op varkensbedrijven, na een dal in 2016, weer gestegen tot gemiddeld $€ 66.000$ per bedrijf. Uitgaande van 3.500 ondernemers betekent dit een totaal investeringsvolume van $€ 230$ miljoen. Er werd vooral geïnvesteerd in gebouwen en installaties, zoals milieuvriendelijke stallen en luchtwassers, om aan milieueisen te voldoen (Programma Vitale Varkenshouderij, 2019). In 2018 nam het gemiddelde investeringsbedrag per bedrijf verder toe naar $€ 83.000$ (www.agrimatie.nl, 2020).

Goede exportpositie naar 3e landen

De exportpositie naar landen buiten de EU is de afgelopen jaren versterkt. De eisen van afnemers op deze markten zijn veel en streng. Nederland heeft aan de hand van gegarandeerde kwaliteitssystemen zoals IKB een goede onderhandelingspositie voor het exporteren naar $3^{\mathrm{e}}$ landen.

Niet van toepassing

- Opkomst korte ketens; 
- Groei multifunctionele landbouw, met Boer-burger contact.

\section{Zwaktes}

Onderhandelingspositie in de keten

De onderhandelingspositie van de primaire ondernemer is zwak. De samenwerking van primaire bedrijven ten opzichte van de afnemers is slecht, mede hierdoor worden zij onderdruk gezet door afnemende partijen.

Niet van toepassing

- Import andere kwaliteit, moeilijk mee te concurreren op prijs

\section{Kansen}

Ondersteuning vanuit beleid (hetzij financieel of door toestaan door leveranciersconglomeraten) De overheid zou door middel van steun of aanscherping van wet- en regelgeving mee kunnen bepalen om het verdienmodel van de ondernemer veilig te stellen door hen te beschermen tegen bepaalde veranderingen in de markt. Of door eisen te stellen aan de minimale prijs voor producten.

Belonen van duurzaamheidsprestaties door verwerkers en consument.

De afgelopen jaren hebben veel Nederlandse varkenshouders geïnvesteerd in duurzamere stallen om te voldoen aan de eisen van de afnemers van varkensvlees. Toch zijn de prijzen van deze investeringen niet altijd terugbetaald aan de ondernemer door de afnemer/markt. Het doorbetalen van de stappen voor een verduurzaming van een bedrijf zou een kans zijn om de positie van de landbouwer te garanderen zodat hij meer buffer heeft voor de verdere doorontwikkeling van zijn bedrijf.

Verbeterde samenwerking (betere afstemming van vraag/aanbod, efficiëntie, kennis) met bijvoorbeeld product organisaties.

Marktconcepten zijn nu veelal onder regie van slachterijen. Een actieve samenwerking en marktstrategie van varkenshouders en samenwerkende partijen kan meer evenwicht geven in krachtsverhoudingen, daarmee kan er tot een evenwichtiger margeverdeling worden gekomen in de keten.

Digitalisering biedt mogelijkheid voor ketengaranties wat gebruikt kan worden om onderscheidend te zijn.

Het gebruik van elektronische oormerken bij vleesvarkens versterkt de mogelijkheden voor tracering van producten tot bedrijfsniveau. Ook versterkt het de informatiestroom tussen schakels (en blockchain kan worden toegepast). Daarnaast kan het gebruikt worden voor nauwkeuriger management, en om faalkosten in de keten te reduceren. Het biedt niet alleen technische voordelen, maar kan ook ingezet worden om vertrouwen van vleeskopers in de herkomst en productkwaliteit te versterken.

Niet van toepassing

- Platform Multifunctionele Landbouw.

\section{Bedreigingen}

Groei van niches kan leiden tot een druk op de prijs

Steeds meer varkenshouders gaan produceren in een nichemarkt waardoor het aanbod in deze markten groter wordt. Om het verdienmodel van de ondernemers in deze niches te garanderen moeten vraag en aanbod goed op elkaar afgestemd blijven.

Sterke concurrentie op de wereldmarkt leidt tot inkomensschommelingen van Nederlandse varkenshouders

De toegenomen afhankelijkheid van de wereldmarkt (afzet vlees, aankoop voer, risico's op grenssluitingen) leidt tot sterkere prijsschommelingen. Bovendien zijn bedrijven door schaalvergroting 
toch al gevoeliger voor inkomensschommelingen (door stijgend aandeel vaste lasten), terwijl de buffers op bedrijven vaak onvoldoende zijn om dergelijke schommelingen op te vangen.

Niet van toepassing

- In dunner bevolkte gebieden minder perspectief voor korte ketens. 
(d) Bijdragen aan mitigatie en adaptatie aan klimaatverandering en leveren van een bijdrage aan een duurzame energieproductie;

SWOT-samenvatting subdoelstelling D Bijdragen aan mitigatie en adaptatie aan klimaatverandering en leveren van een bijdrage aan een duurzame energieproductie

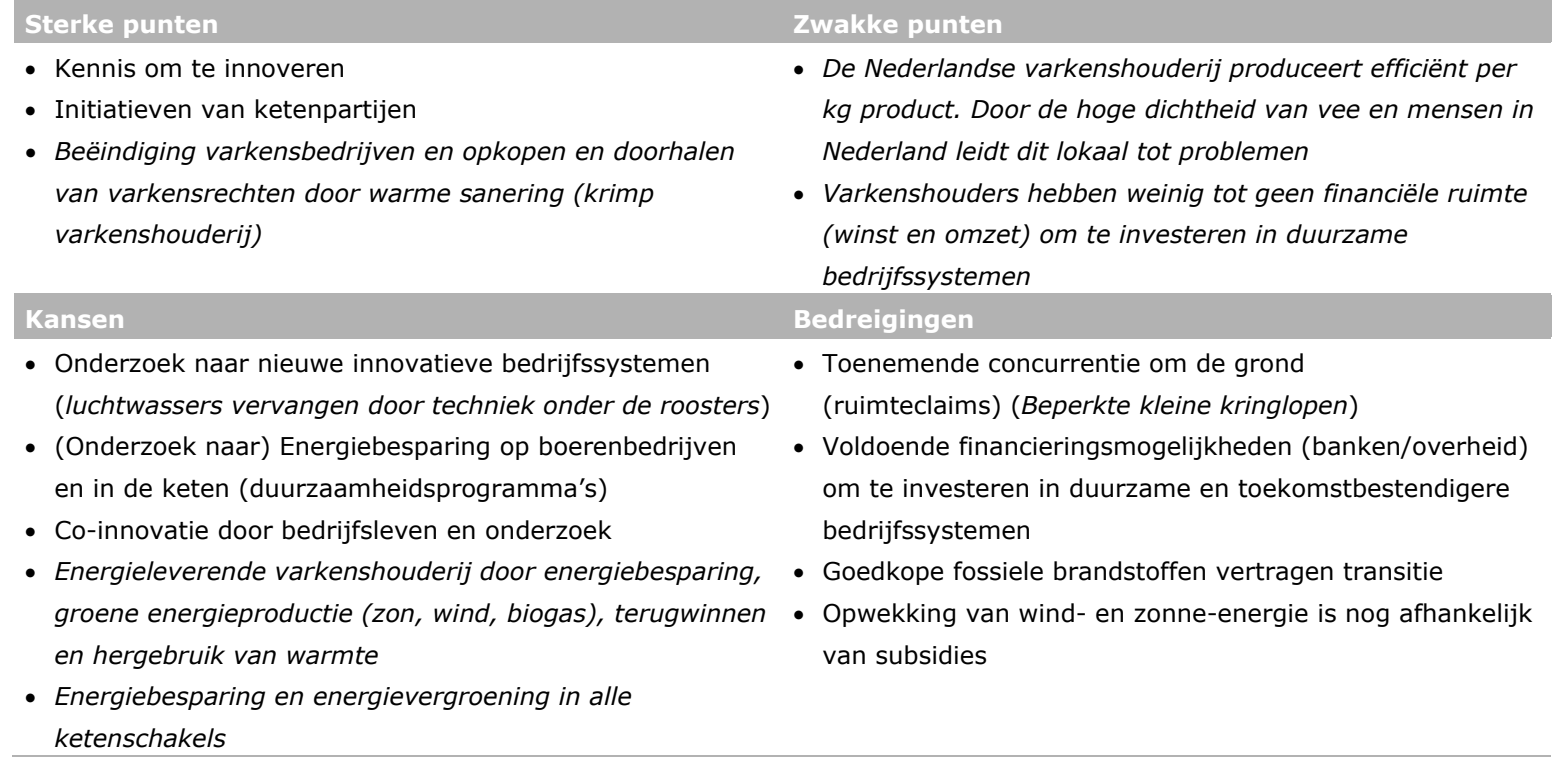

De analyse van de sterke en zwakke punten is volledig anders.

\section{Sterke punten}

Beëindiging varkensbedrijven en opkopen en doorhalen van varkensrechten door warme sanering (krimp varkenshouderij)

De krimp van de varkensstapel in Nederland leidt tot minder uitstoot voor de hele varkenssector.

\section{Zwaktes}

Financiële ruimte (winst en omzet) om te investeren in duurzame bedrijfssystemen.

De marges in de keten zijn onvoldoende om nog meer te investeren in een verdere verduurzaming.

Als tweede ondervinden varkenshouders hinder van het steeds strenger wordende en stapelend beleid, waardoor moeilijk strategische aanpassingen door te voeren zijn.

\section{Kansen}

Energiebesparing en energievergroening in alle ketenschakels

Doormiddel van onderzoek, innovatie en investeringen in energieneutrale/energie verminderende systemen zouden in alle schakels van de keten energievermindering plaats kunnen vinden.

\section{Bedreigingen}

Goedkope fossiele brandstoffen vertragen transitie.

Omdat fossiele brandstoffen nog altijd een lage prijs hebben wordt er minder geïnvesteerd in duurzamere brandstoffen.

Opwekking van wind- en zonne-energie is nog afhankelijk van subsidies

De investeringen voor zonnepanelen of windmolens zijn vanuit de markt nog altijd te duur. Er kan dus alleen nog maar geïnvesteerd worden als er subsidie voor gegeven is. 


\section{(e) Bevorderen van duurzame ontwikkeling en efficiënt beheer van natuurlijke hulpbronnen, zoals water, bodem en lucht;}

SWOT-samenvatting subdoelstelling E Bevorderen van duurzame ontwikkeling en efficiënt beheer van natuurlijke hulpbronnen, zoals water, bodem en lucht

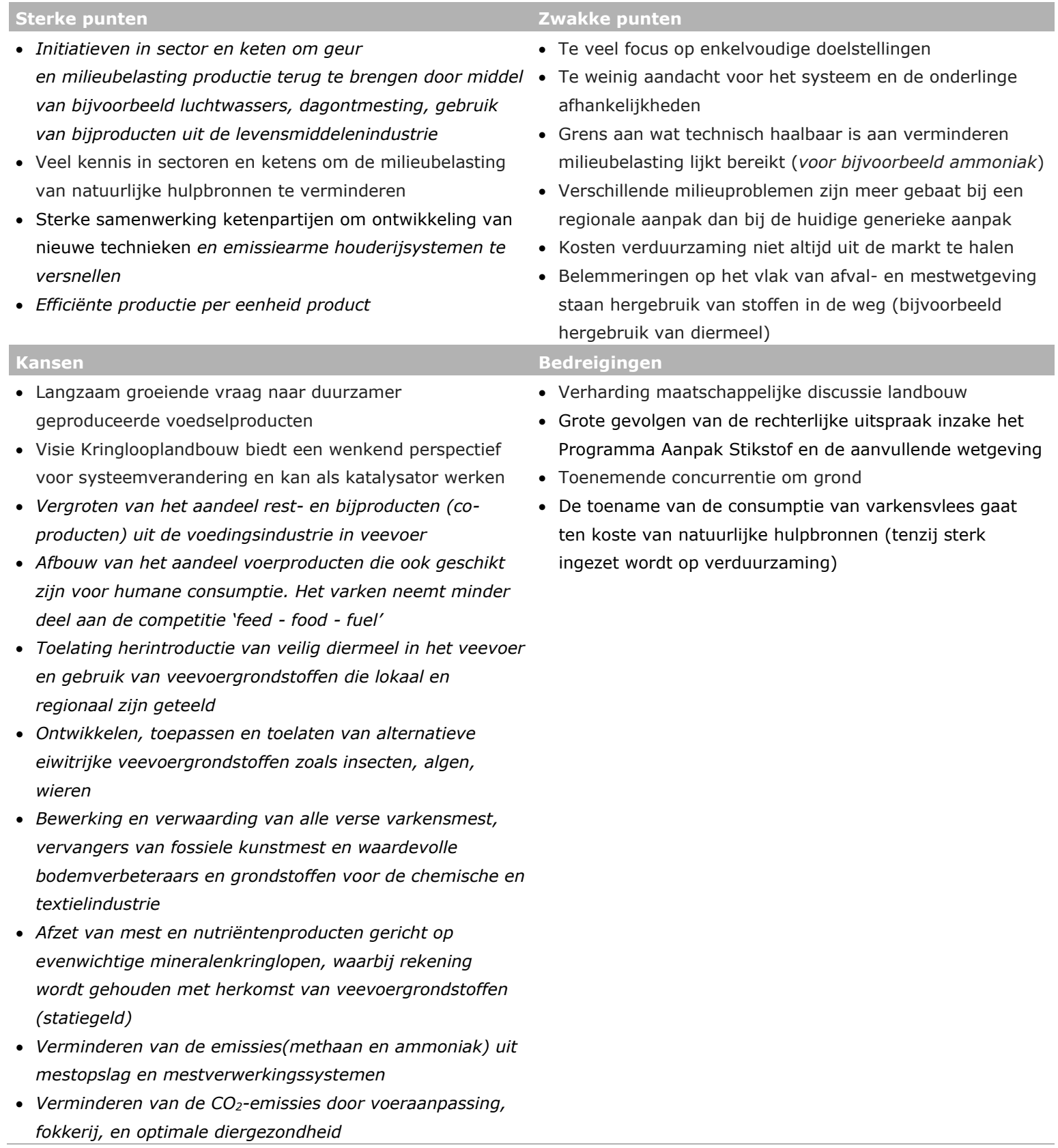

\section{Sterktes}

\section{Efficiënte productie per eenheid product}

De varkenshouderij heeft zich ontwikkeld tot een zeer efficiënt systeem van varkensvleesproductie, met zo min mogelijk milieubelasting.

Verbetering van de leefomgeving door het saneren van bedrijfslocaties die geuroverlast veroorzaken in de regio's Zuid en Oost van de meststoffenwet.

De Subsidieregeling sanering varkenshouderijen (Srv) die eind 2020 is ingegaan zorgt voor een krimp in de varkensstapel in Nederland en een vermindering van geuroverlast op specifieke locaties. Door de krimp wordt ook de uitstoot van broeikasgassen verlaagd. Om toch aan de vraag naar varkensvlees in de wereld te kunnen voldoen zullen elders in de wereld meer varkens worden gehouden. Op 
wereldschaal zal dit daarom geen effect hebben. Echter op lokaal en regionaal niveau is er minder belasting op water, bodem en lucht.

\section{Zwakten}

Kosten verduurzaming niet altijd uit de markt te halen.

De kosten van verduurzaming komen in de regel op kosten van de boeren, zonder mogelijkheid om deze kosten door te belasten aan afnemers. Dit leidde tot kostenverlaging door efficiëntieverbetering en schaalvergroting, maar dat is een eindig verhaal. Met de introductie van brede marktconcepten (zoals Beter Leven) is hier wel enig perspectief ontstaan, doordat afnemers (supermarkten en daarmee consumenten) betalen voor aanvullende eisen die zij stellen.

Te veel focus op enkelvoudige doelstellingen

Wetgeving is weinig consistent qua doelen, tradeoffs en timing. Milieu- en dierenwelzijnseisen staan deels haaks op elkaar. Speelruimte om te innoveren is soms beperkt (denk aan goedkeuringstrajecten voor emissiebeperkende systemen), wat in combinatie met langdurige vergunningstrajecten en magere marges niet bevorderlijk is voor innovatie. Ook wetgeving over hergebruik van spuiwater van luchtwassers (als kunstmestvervanger) wordt door ondernemers als traag en belemmerend ervaren.

\section{Kansen}

Onderzoek naar nieuwe innovatieve bedrijfssystemen. Oplossingen voor een klimaat neutralere veehouderij.

Het ontwikkelen van nieuwe stalsystemen met brongerichte emissiebeperkende maatregelen in bestaande en nieuwe stallen is essentieel. Hierbij wordt in de komende jaren toegewerkt naar het verder reduceren van de uitstoot van milieubelastende stoffen zoals ammoniak, broeikasgassen, geur en fijnstof. Er worden nieuwe stalconcepten ontwikkeld, die passen bij een diervriendelijke houderij, bij wensen van de markt en consument, die invulling geven aan brandveiligheid, met robuuste en gezonde dieren en die een bijdrage leveren aan het behalen van milieu- en klimaatdoelen en de circulaire economie.

Vergroten van het aandeel rest- en bijproducten (co-producten) uit de voedingsindustrie in veevoer. Eén van de ambities van de Coalitie Varkenshouderij is om het aandeel reststromen in het veevoer in de periode tot 2030 met minimaal $10 \%$ te verhogen, onder voorwaarde van de beschikbaarheid van goede grondstoffen. Het vergroten van het aandeel voer uit reststromen draagt bij aan een duurzame ontwikkeling en efficiënt beheer van natuurlijke hulpbronnen. Dit plan draagt bij aan de afbouw van het aandeel voerproducten die ook geschikt zijn voor humane consumptie. Het varken neemt hierbij minder deel aan de competitie 'feed-food-fuel'.

\section{Het weer opnieuw toelaten van diermeel in veevoer}

Diermeel is een eiwitrijk product dat vrijkomt als restproduct van de vleesindustrie. Dit zou als goede eiwitbron in veevoer benut kunnen worden, waardoor minder behoefte is aan andere eiwitgrondstoffen zoals sojaschroot. Het herbenutten is door Europese regels echter (nog) niet toegestaan.

\section{Bedreigingen}

Toenemende concurrentie om de grond (ruimteclaims)

In de huidige opzet van de varkensproductie wordt een (beperkt) deel van de veevoergrondstoffen van buiten de EU gehaald; bovendien wordt een deel van de mest naar onze buurlanden geëxporteerd. Waar diverse ruimteclaims zijn en de grond duur, is het des te moeilijker om de grondloze houderij alsnog aan grond te binden.

Niet van toepassing

- Noodzaak tot aanpassing grondgebruik vanwege klimaatverandering

- Verzilting en verslemping groeiend probleem

- Waterbeheer een grotere uitdaging als gevolg meer droge jaren en meer piekbelasting 
(f) Bijdragen tot de bescherming van de biodiversiteit, versterken van ecosysteemdiensten en in stand houden van Habitats en landschappen.

\begin{tabular}{|c|c|}
\hline Sterke punten & Zwakke punten \\
\hline $\begin{array}{l}\text { De diversiteit van het Nederlandse landschap door de } \\
\text { ligging in een vruchtbare delta, de variatie in } \\
\text { grondsoorten en de ontginningsgeschiedenis } \\
\text { - Ontwikkelingen in de keten om biodiversiteit in de } \\
\text { landbouw te belonen }\end{array}$ & $\begin{array}{l}\text { - De zeer zorgelijke toestand van biodiversiteit, } \\
\text { ecosysteemdiensten en landschappen in het landelijk } \\
\text { gebied en het vooralsnog ontbreken van een positieve } \\
\text { trend } \\
\text { - Biodiversiteit maakt vrijwel geen deel uit van de } \\
\text { agrarische bedrijfsvoering, inspanningen voor de } \\
\text { versterking van biodiversiteit worden veelal onvoldoende } \\
\text { beloond } \\
\text { - Het betalen voor biodiversiteit door de markt en de } \\
\text { consument is nog geen gemeengoed }\end{array}$ \\
\hline Kansen & Bedreigingen \\
\hline
\end{tabular}

Varkenshouderij heeft een indirecte relatie met biodiversiteit. Bij de teelt van veevoergewassen zijn er zorgen over het verminderen van de soortenrijkdom. Dit hangt vooral sterk samen met gewassen die buiten Europa geteeld worden, zoals soja of palmproducten. In de industrie zijn afspraken gemaakt (RTRS, Fefac Sourcing Guidelines, RPSO) om eisen te stellen aan de productie ervan.

Verder is er een verband tussen ammoniakemissie uit varkensstallen en biodiversiteit. De varkenssector heeft al wel veel bereikt qua vermindering van de ammoniakemissie. De ammoniakemissie in de varkenshouderij is tussen 1990 en 2000 gehalveerd en tussen 2000 en 2010 met een derde gedaald. Ook tussen 2010 en 2018 daalde die weer met een derde. Daarmee komt de totale daling van de ammoniakemissie in de varkenshouderij tussen 1990 en 2018 uit op ruim $81 \%$ (www.agrimatie.nl, 2020).

Er is qua aanvliegroute een duidelijke samenhang met doel E (Bevorderen van duurzame ontwikkeling en efficiënt beheer van natuurlijke hulpbronnen, zoals water, bodem en lucht). 


\subsection{Referenties}

Agrimatie. (2020). Sectorresultaat varkenshouderij aantal bedrijven. Geraadpleegd op 18 februari 2021, opgehaald van:

https://www.agrimatie. nl/SectorResultaat.aspx?subpubID=2232\&sectorID =2255\&themaID =2267

Berkhout, Petra, Jakob Jager en Bert Smit, (2019). Inkomenseffecten van de GLB-aanpassingen per 2020; Een quick scan. Wageningen, Wageningen Economic Research, Rapport 2019-114

CBS. (2020). Krimp in aantal bedrijven met varkens. Geraadpleegd op 19 februari 2021, opgehaald van: www.cbs.nl

Dagevos, H., Verhoog, D., van Horne, P., \& Hoste, R. (2020). Vleesconsumptie per hoofd van de bevolking in Nederland, 2005-2019. (Wageningen Economic Research nota; No. 2020-078). Wageningen Economic Research. https://doi.org/10.18174/531409

Ferneij P., J. P. V. (2018). Nederlandse Varkenshouderij van de toekomst. Geraadpleegd op 15 februari 2021, opgehaald van: https://www.rabobank.nl/bedrijven/cijfers-entrends/veehouderij/varkensstudie-toekomst-varkenshouderij/:

https://www.rabobank.nl/bedrijven/cijfers-en-trends/veehouderij/varkensstudie-toekomstvarkenshouderij/

Hoste, R. (2020). International comparison of pig production costs 2018: Results of InterPIG. (Wageningen Economic Research report; No. 2020-007). Wageningen Economic Research. https://doi.org/10.18174/511876

Jukema, G.D., P. Ramaekers en P. Berkhout (Red.) (2021). De Nederlandse agrarische sector in internationaal verband - editie 2021. Wageningen/Heerlen/Den Haag, Wageningen Economic Research en Centraal Bureau voor de Statistiek, Rapport 2021-001. 126 blz.; 45 fig.; 38 tab.; 117 ref.

Peet, G. van der, Leenstra, F., Vermeij, I., Bondt, N., Puister, L., \& van Os, J. (2018). Feiten en cijfers over de Nederlandse veehouderijsectoren 2018. Wageningen, Wageningen Livestock Research, rapport 1134. https://doi.org/10.18174/464128 


\subsection{Bijlage Indicatoren}

N.B. Alle data zijn op basis van Eurostat of nationale data als in Eurostaat geen gegevens beschikbaar waren op deelsectorniveau.

Indicatoren C.12 tot en met C.34

Tabel C.12 Aantal bedrijven naar bedrijfsgrootte en in ha en standaardopbrengst

\begin{tabular}{lrrr} 
& \multicolumn{3}{c}{ Varkensbedrijven } \\
\cline { 2 - 4 } Aantal bedrijven naar omvang in ha & 2010 & 2015 & 2020 \\
\hline$<1$ ha & 786 & 657 & 494 \\
\hline $1-5$ ha & 1.096 & 704 & 495 \\
\hline $5-10$ ha & 899 & 681 & 471 \\
\hline $10-30$ ha & 1.326 & 968 & 721 \\
\hline $30-50$ ha & 276 & 213 & 179 \\
\hline$>50$ ha & 131 & 142 & 156 \\
\hline Totaal & 4.514 & 3.365 & 2.516 \\
\hline
\end{tabular}

Aantal bedrijven naar omvang in standaardopbrengst (SO)

SO: $3.000-25.000$ euro

$49 \quad 30 \quad 16$

SO: $25.000-100.000$ euro

$593 \quad 359 \quad 116$

SO: $100.000-250.000$ euro

$1.063 \quad 610 \quad 307$

SO: $250.000-500.000$ euro

1.228

$672 \quad 398$

SO: $500.000-1.000 .000$ euro

1.047

$888 \quad 702$

SO: $1.000 .000-1.500 .000$ euro

$323 \quad 423 \quad 403$

SO: $1.500 .000-3.000 .000$ euro

SO: $>3.000 .000$ euro

34

301

Totaal

4.465

3.335

Tabel C.13a Arbeidsinzet - in arbeidsjaareenheden

\begin{tabular}{lrrr} 
Varkensbedrijven & 2010 & 2015 & 2020 \\
Arbeidsjaareenheden (regelmatig en onregelmatig) Regulier werkzaam & 8.345 & 6.912 a) & 6.059 a) \\
\hline Man & 6.197 & 2.491 & 2.534 \\
\hline Vrouw & 2.148 & 1.486 & 1.268 \\
\hline Niet-reguliere arbeidsinzet & 287 & 440 & 335 \\
\hline
\end{tabular}

a): optelsom van mannelijke en vrouwelijke werknemers in aje komt niet overeen met totaal.

Tabel C.13b Arbeidsinzet: aantal arbeidsjaareenheden naar gezinsarbeid en vreemde arbeid

\begin{tabular}{llll} 
Varkensbedrijven & 2010 & 2015 & 2020 \\
\hline gezin & 6.471 & 5.047 & 3.930 \\
\hline Niet-gezin & 2.162 & 2.306 & 2.464 \\
\hline
\end{tabular}

Tabel C.14 Leeftijdsopbouw agrarische bedrijfshoofden

\begin{tabular}{lrrr} 
Varkensbedrijven & 2010 & 2015 & 2020 \\
$<40$ jaar (A) & 502 & 253 & 193 \\
\hline$>55$ jaar (B) & 2.490 & 1.808 & 1.082 \\
\hline Totaal & 4.514 & 3.365 & 2.516 \\
\hline ratio (A/B) & 20 & 14 & 18 \\
\hline
\end{tabular}

Source: Dutch Farm Structure 
Tabel C.16 Bedrijfsopvolging

\begin{tabular}{|c|c|c|c|}
\hline Varkensbedrijven & 2012 & 2016 & 2020 \\
\hline aandeel bedrijven met een opvolger & 678 & 555 & 559 \\
\hline aantal bedrijven met een bedrijfshoofd $>51$ jaar & 1.854 & 1.665 & 1.459 \\
\hline aandeel bedrijven met een opvolger & 37 & 33 & 38 \\
\hline
\end{tabular}

Tabel C.17 Areaal gewassen op varkensbedrijven

\begin{tabular}{lrrr} 
& 2010 & 2015 & 2020 \\
Akkerbouwland & 23.351 & 17.034 & 18.499 \\
\hline Blijvend grasland & 16.354 & 12.623 & 10.940 \\
\hline Blijvende teelten & 242 & 308 & 274 \\
\hline Overig & 13.916 & 14.346 & 8.083 \\
\hline Totaal & 53.864 & 44.311 & 37.795 \\
\hline
\end{tabular}

C18-C23: niet beschikbaar

Tabel C.24 Netto toegevoegde waarde per aje (in euro)

\begin{tabular}{lrrrrrrr} 
& 2010 & 2012 & 2014 & 2016 & 2018 & 2019 \\
\hline Varkensbedrijven (in euro) & 41.711 & 65.847 & 31.086 & 112.855 & $34.440,62$ & 193.431 \\
\hline Index $(2010=100)$ & 100 & 158 & 75 & 271 & 83 & 464 \\
\hline
\end{tabular}

Tabel C.25 Inkomen uit bedrijf per oaje (in euro)

\begin{tabular}{lrrrrrr} 
& 2010 & 2012 & 2014 & 2016 & 2018 & 2019 \\
Varkensbedrijven (in euro) & 14.200 & 46.003 & -2.072 & 125.616 & 8.235 & 281.699 \\
\hline Index $(2010=100)$ & 100 & 324 & -15 & 885 & 58 & 1.984 \\
\hline
\end{tabular}

C.26 niet beschikbaar

C.27 niet beschikbaar

C.28 niet beschikbaar

C. 29 niet beschikbaar

C.30 Handel.

C.31 Niet beschikbaar 
Tabel C.32 Areaal biologische landbouw en aandeel areaal biologische landbouw op totale areaal landbouwgrond in gebruik bij varkensbedrijven

\begin{tabular}{|c|c|c|c|c|c|c|}
\hline \multirow[t]{2}{*}{ Aantal hectares } & \multicolumn{6}{|c|}{ Varkensbedrijven } \\
\hline & 2015 & 2016 & 2017 & 2018 & 2019 & 2020 \\
\hline Totaal areaal biologisch plus in omschakeling & 418 & 425 & 696 & 606 & 780 & 722 \\
\hline Areaal in omschakeling & 25 & 36 & 104 & 99 & 188 & 134 \\
\hline Totaal areaal & 49.095 & 46.127 & 40.559 & 40.553 & 39.900 & 41.681 \\
\hline \multicolumn{7}{|l|}{ Aandeel (\%) } \\
\hline Totaal areaal biologisch plus in omschakeling & 0,9 & 0,9 & 1,7 & 1,5 & 2,0 & 1,7 \\
\hline Areaal biologisch & 0,8 & 0,8 & 1,5 & 1,3 & 1,5 & 1,4 \\
\hline Areaal in omschakeling & 0,1 & 0,1 & 0,3 & 0,2 & 0,5 & 0,3 \\
\hline Totaal areaal & 100 & 100 & 100 & 100 & 100 & 100 \\
\hline
\end{tabular}

Tabel C.33 Intensieve landbouw, aandeel areaal met een hoge inputintensiteit (grond met een totale input van veevoer, kunstmest en gewasbeschermingsmiddelen van meer dan $€ 350$ per ha)

$\begin{array}{lrrr}\text { Aandeel } & 2010 & 2015 & 2019 \\ \text { Varkensbedrijven } & 1 & 12 & 20\end{array}$

\section{C.34 niet beschikbaar}

Indicatoren C.35-C.48

C.35 niet beschikbaar naar type bedrijf

C.36 niet beschikbaar naar type bedrijf

C.38 niet beschikbaar naar type bedrijf

C.40 niet beschikbaar naar type bedrijf

C.41 niet beschikbaar naar type bedrijf

C.42 niet beschikbaar naar type bedrijf

C.43 niet beschikbaar naar type bedrijf

C.44 niet beschikbaar naar type bedrijf

C. 45 niet beschikbaar naar type bedrijf

Tabel C.46 Ammoniakemissies (1.000 ton NH3)

\begin{tabular}{lrrr} 
& 2010 & 2015 & 2019 \\
Varkensbedrijven & 30 & 21 & 18 \\
\hline Source: Agrimatie/Emissieregistratie. & & &
\end{tabular}

C. 47 niet beschikbaar naar type bedrijf

Tabel C.48 Afzet van pesticiden (1.000 ton werkzame stof)

\begin{tabular}{rrrr} 
& 2010 & 2015 & 2019 \\
Varkenshouderij & 0,06 & 0,08 & 0,08 \\
\hline
\end{tabular}




\section{$7 \quad$ SWOT- analyse deelsector Vleeskuikenhouderij}

Mariel Benus en Peter van Horne

N.B. deze analyse moet worden gelezen in samenhang met de SWOT-analyse op het niveau van de landbouw als geheel. Onderhavige analyse verbijzondert de SWOT-analyse waar nodig naar de deelsector in kwestie.

\subsection{Algemene beschrijving van de vleeskuikenhouderij}

De Nederlandse vleeskuikensector

De pluimveesector kent productierechten, waardoor het totaal aantal kippen in Nederland begrensd is. Maar uitwisseling tussen ouderdieren, vleeskuikens en leghennen is wel mogelijk. Op circa 200 vermeerderingsbedrijven met circa 6 miljoen dierplaatsen worden jaarlijks 1 miljard broedeieren voor de vleeskuikenproductie geproduceerd, waarvan ruim 30\% (300 miljoen broedeieren) wordt geëxporteerd. 17 broederijen broeden jaarlijks gezamenlijk circa 540 miljoen kuikens uit (ca. 20\% van de broedeieren levert geen kuiken op), waarvan ongeveer 20\% (108 miljoen kuikens) geëxporteerd wordt. Ruim 500 vleeskuikenbedrijven met een gemiddelde omvang van een kleine 100.000 dierplaatsen hebben in totaal 48 miljoen dierplaatsen en leveren jaarlijks 395 miljoen vleeskuikens (in 6-8 rondes, want een vleeskuiken leeft gemiddeld 6 weken) aan slachterijen in Nederland(Van der Peet et al., 2018).

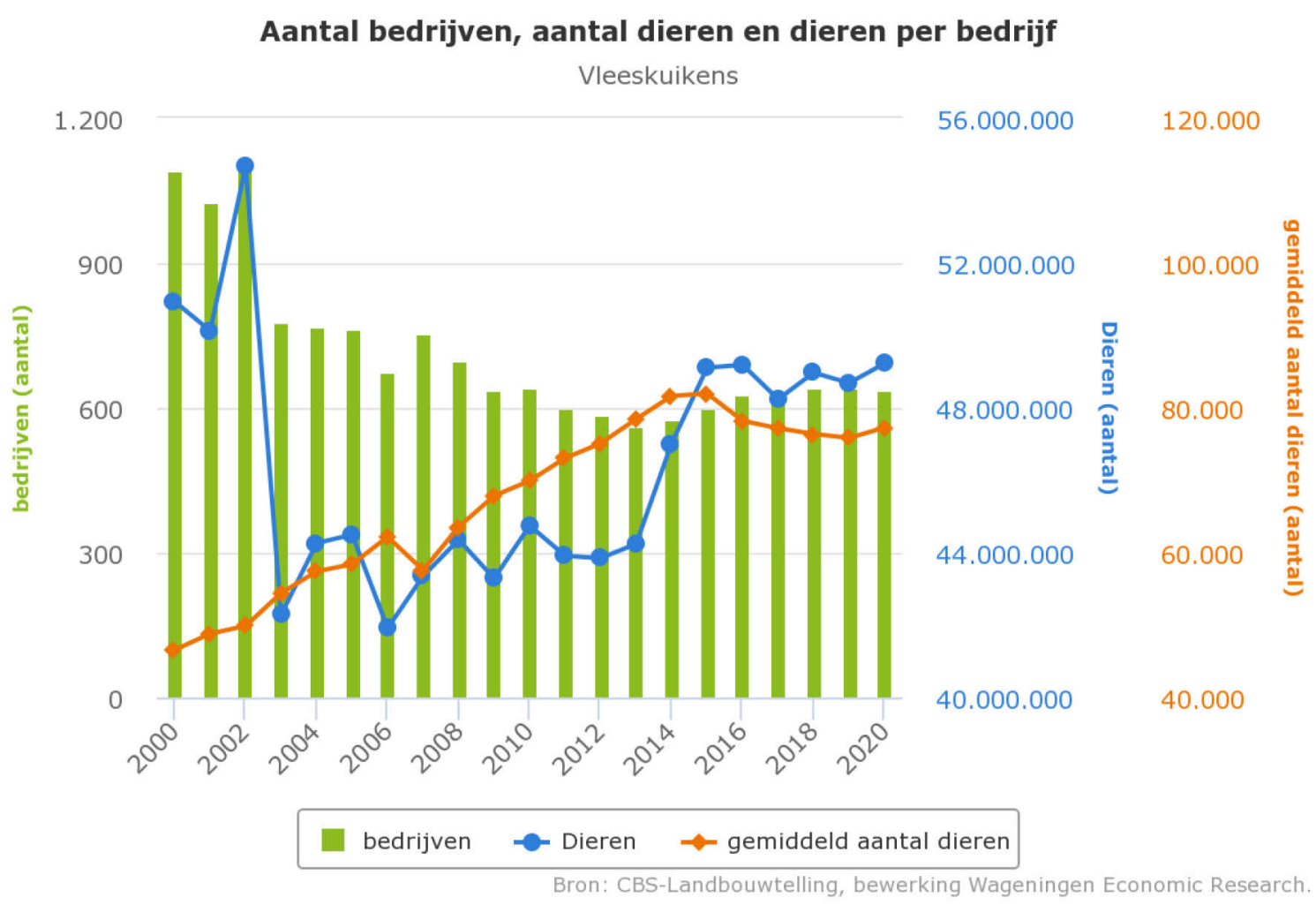

Figuur 1 Aantal bedrijven en aantal dieren per bedrijf in Nederland

De figuur geeft een beeld van de ontwikkelingen in het totaal aantal vleeskuikens in Nederland, het aantal bedrijven met vleeskuikens en het aantal vleeskuikens per bedrijf. De daling van het 
(gemiddeld) aantal vleeskuikens per bedrijf vanaf 2016 wordt veroorzaakt door de introductie van diverse marktconcepten met een lagere bezettingsgraad en tragere groei van de vleeskuikens. Opvallend is dat het aantal vleeskuikenbedrijven vanaf 2013 is toegenomen.

\section{Productiesysteem}

Tot het midden van de vorige eeuw was vrijwel al het pluimveevlees op de Nederlandse markt afkomstig van uitgelegde hennen en van haantjes van legrassen die voor hun vlees werden gehouden. Vanaf 1950 werden vanuit de VS gespecialiseerde vleeskuikens geïntroduceerd. Nederlandse fokbedrijven importeerden fokdieren uit de VS en ontwikkelden de gespecialiseerde vleeskuikens verder. In 1958 was al 30\% van de Nederlandse pluimveevleesproductie van specifieke vleesrassen en in 1962 65\%, waarbij niet zo zeer sprake was van vervanging, maar vooral van uitbreiding van de totale productie. Deze ontwikkeling van de pluimveevleesproductie vond vooral in Noord Brabant en Limburg plaats. Tot ca. 1970 werden nog wel haantjes van legrassen voor de vleesproductie gebruikt. Daarna was alle kuikenvleesproductie in Nederland van specifieke vleesrassen. Vleeskuikens zijn van een specifieke kruising, gericht op efficiënte vleesproductie door een hoog groeivermogen (in de tweede helft van de 20ste eeuw is de groeisnelheid van vleeskuikens verviervoudigd door genetische selectie). Wereldwijd zijn er twee fokbedrijven (Aviagen, eigendom van Wessjohann, een Duits familiebedrijf) en Cobb (Verenigde Staten), die de fokkerij van vleeskuikens tot aan de grootouderdieren volledig onder controle hebben. Zij vermarkten ouderdieren van verschillende 'merken' en types. (Van der Peet et al., 2018).

Een recente ontwikkeling is de omschakeling van vleeskuikenhouders naar langzaam groeiende vleeskuikens. Dit zijn de vleeskuikens die worden gehouden volgens de criteria van de Kip van morgen of scharrelkuikens (Beter Leven Keurmerk 1 ster). In 2020 is het aandeel langzaam groeiende vleeskuikens opgelopen tot één derde van het totaal aantal gehouden kuikens. De Nederlandse Retail verkoopt uitsluitend pluimveevlees van langzaam groeiende vleeskuikens. Reguliere vleeskuikens worden afgezet in de foodservice en gaan weg voor export.

\section{Aandeel biologische productie}

Het aandeel biologische vleeskuikens in Nederland is minder dan 0,1\% van de totale productie. Er zijn twee bedrijven die op iets grotere schaal (ca. 20.000 kuikenplaatsen) biologische vleeskuikens produceren. Exacte gegevens over hun omvang en productie zijn niet bekend. Er worden ook biologische vleeskuikens geïmporteerd, met name uit België.

\section{Werkgelegenheid}

Elke pluimveehouder geeft in de keten werk aan 18 personen.Dit zijn voornamelijk werknemers die verderop in de keten werken zoals medewerkers in slachterijen, handel en verwerking. De totale vleespluimveesector biedt werk aan 16.000 personen (Van Horne, 2020). Uitgaande van ruim 500 vleeskuikenbedrijven zou het in dat deel van de sector dan gaan om werkgelegenheid voor naar schatting 9.000 personen. Naast werkgelegenheid op het primaire bedrijf zijn er veel arbeidsplaatsen in de toeleverende industrie (onder andere mengvoerbedrijven) en de verwerkende industrie (onder andere pluimveeslachterijen). 


\subsection{SWOT- analyse per specifieke doelstelling}

\section{(a) Bieden van steun met het oog op een leefbaar landbouwinkomen en veerkracht in de hele Unie om de voedselzekerheid te vergroten;}

SWOT-samenvatting subdoelstelling A Bieden van steun met het oog op een leefbaar landbouwinkomen en veerkracht in de hele Europese Unie om de voedselzekerheid te vergroten

\section{Sterke punten}

- Vakmanschap vleeskuikenhouders met goede technische resultaten

- Marktgerichte productie

- Innovatief vermogen (nieuwe producten voor de consument etc.)

- Structuur met gezinsbedrijven met inzet van eigen arbeid en kapitaal door ondernemer, daardoor veerkracht

- Gunstige productieomstandigheden, infrastructuur

- Goede infrastructuur voor financiering (banken)

\section{Zwakke punten}

- Beperkte mogelijkheden voor bedrijfsontwikkeling door milieuregelgeving (strikt vergunningenbeleid) en dure productierechten

- Hoge kostprijs (ten opzichte van andere EU landen en niet-EU-landen) als gevolg van dure stallen en arbeid

- Inkomens landbouw lager ten opzichte van vergelijkbaar werk buiten de landbouw

- Merendeel van de huidige bedrijven in de land- en tuinbouw is te klein om een marktconforme beloning voor de inzet van eigen arbeid en kapitaal te realiseren

- Onderhandelingspositie in de keten zwak

- Werken buiten de landbouw is financieel aantrekkelijker

- Sterke vermogenspositie bemoeilijkt bedrijfsovernames

- Rendement op eigen vermogen en arbeid lager dan in sectoren buiten de landbouw

Kansen Bedreigingen

- Gunstig imago pluimveevlees

- Pluimveevlees is heel geschikt product voor de horeca en als ingrediënt in kant-en-klaar- maaltijden

- Groeiende markt voor speciale concepten en korte ketens

- Verbeteren van de samenwerking in ketens (onder andere broederijen en voerfabrieken) om efficiëntie verder te verhogen

- Aantrekkingskracht werk buiten de sector, jonge boeren kiezen bewust voor baan buiten de landbouw (is deels ook een kans omdat het ruimte schept voor andere bedrijven om door te groeien)

- Vleesconsumptie zal de komende decennia mogelijk gaan afnemen

- Bedrijfsovername niet eenvoudig door kapitaalintensiteit bedrijven

- Na bedrijfsovername is aantrekken vreemd vermogen lastig gegeven zware financiering

- Financieringslasten bij overname

- Ongelijk speelveld; markt neemt producten af uit buitenland die onder andere - veelal lagere - eisen zijn geproduceerd

\section{Sterktes}

\section{Gunstige productieomstandigheden}

In 2020 werden op 507 bedrijven vleeskuikens gehouden, vooral gespecialiseerde bedrijven met gangbare vleeskuikens. De inkomenssituatie in de gangbare vleeskuikenhouderij is redelijk stabiel. De afgelopen vier jaar (2017-2020) was het inkomen uit het bedrijf gemiddeld ruim $€ 100.000$ per onbetaalde arbeidsjaareenheid. In 2019 is de gemiddelde solvabiliteit (percentage eigen vermogen) $61 \%$. Er zijn tussen de bedrijven grote verschillen in solvabiliteit.

\section{Zwaktes}

Hoge kostprijs ten opzichte van niet- EU landen als gevolg van dure grond, arbeid en mestafzet De vleeskuikenshouderij in Nederland heeft hogere productiekosten dan omringende landen. Dit komt door een combinatie van iets hogere voerkosten, duurdere huisvestings- en arbeidskosten en mestafzetkosten. 


\section{Kansen}

Pluimveevlees heeft een gunstig imago in vergelijking met andere vleessoorten. De consumptie van pluimveevlees in de EU zal naar verwachting toenemen tot $24,6 \mathrm{~kg}$ per hoofd in 2030 ( $+1,2 \mathrm{~kg}$ in vergelijking met 2020), omdat consumenten pluimveevlees zien als een goedkoop, gezond en duurzaam product. Ook de vraag in een aantal exportbestemmingen zal toenemen.

Groeiende markt voor speciale concepten

De laatste jaren worden er steeds meer vleeskuikens gehouden in het tussensegment. Sinds 2014 zijn er diverse concepten met langzaam groeiende vleeskuikens, waarvan de Nederlands supermarktkip en Beter Leven keurmerk (1 ster) de belangrijkste zijn. In 2020 was het aandeel langzaam groeiende vleeskuikens een derde van het totaal aantal dierplaatsen in Nederland. Dit aandeel zou verder kunnen groeien als ook de foodservice en de omringende landen vraagt om concepten.

Niet van toepassing

- Vraag naar publieke diensten (nieuw GLB)

- Sterke verstedelijking van het Nederlandse platteland geeft kansen voor directe verbindingen met de stad via het leveren van producten en diensten

- Inzet Platform Multifunctionele Landbouw om knelpunten in ontwikkeling multifunctionele landbouw weg te nemen en ontwikkelruimte te creëren

\section{Bedreigingen}

Jonge boeren kiezen bewust voor baan buiten de landbouw. Op 44\% van de vleeskuikenbedrijven met een bedrijfsleider $>51$ jaar is een opvolger aanwezig.

Vleesconsumptie zal de komende decennia mogelijk gaan afnemen, door de beoogde eiwittransitie. De mate van vleesconsumptie blijkt onder andere samen te hangen met het inkomensniveau. Hierbij neemt de consumptie toe met stijgend inkomen, tot een bepaald verzadigingsniveau, waarna de vleesconsumptie iets afneemt. In West-Europa daalt mogelijk de komende decennia naar verwachting de vleesconsumptie. Dit door de negatieve aandacht op de verschillende aspecten van vlees (gezondheid, klimaat, milieu, dierenwelzijn).

Niet van toepassing

- Inkomensondersteunende en stabiliserende werking toeslagen neemt verder af

- Hoge grondprijs en arbeid belemmeren extensivering.

\footnotetext{
1 https://ec.europa.eu/info/news/eu-agricultural-outlook-2020-30-sustainability-objectives-impact-meat-and- dairy-alongsupply-chain-2020-dec-16_en
} 
(b) Vergroten van de marktgerichtheid en van het concurrentievermogen, onder meer door beter te focussen op onderzoek, technologie en digitalisering;

SWOT-samenvatting subdoelstelling B - Vergroten van de marktgerichtheid en van het concurrentievermogen, onder meer door beter te focussen op onderzoek, technologie en digitalisering

\begin{tabular}{|c|c|}
\hline & \\
\hline $\begin{array}{l}\text { - Gunstige ligging van Nederland voor de afzet van verse } \\
\text { producten in omringende landen } \\
\text { - Vleeskuikensector kent in Nederland veel sterke } \\
\text { internationale toeleverende bedrijven, bijv. in fokkerij, } \\
\text { vleesverwerkingstechnologie, broedmachines, } \\
\text { voerproductie etc. (verenigd in Dutch Poultry Centre) } \\
\text { - Innovaties in technieken, producten, processen } \\
\text { - Goede uitgangspositie logistiek, infrastructuur, } \\
\text { organisatie sectoren (zie ook tabel bij doelstelling a); } \\
\text { middelgrote en grote slachterijen met goede en efficiënte } \\
\text { ketenorganisatie }\end{array}$ & $\begin{array}{l}\text { - Grootschaligheid en intensiteit productie, toenemende } \\
\text { discussie over 'megastallen', ziektedruk (onder andere } \\
\text { vogelgriep) en angst voor zoönose ('licence to produce') } \\
\text { - Druk op het gebruik van antibiotica, coccidiostatica en andere } \\
\text { medicijnen of bestrijdingsmiddelen maakt intensieve productie } \\
\text { lastiger } \\
\text { - Arbeidsomstandigheden in onder meer de vleesverwerkende } \\
\text { industrie zijn niet aantrekkelijk en deze bedrijven hebben een } \\
\text { negatief imago (Nederlanders willen er niet werken) } \\
\text { - Onder andere Duitsers en Britten kiezen steeds vaker voor } \\
\text { producten uit eigen land } \\
\text { - Nederlands pluimveevlees heeft (nog) geen sterk merk in de } \\
\text { markt }\end{array}$ \\
\hline Kansen & \\
\hline $\begin{array}{l}\text { - Toenemende vraag maatschappij naar duurzamere } \\
\text { producten, onder andere behoefte aan meer } \\
\text { - Verdenwelzijn } \\
\text { kuikenvlees met afzet in Nederland en mogelijk export } \\
\text { naar Duitsland en het VK } \\
\text { - Versterken van het imago van het Nederlandse } \\
\text { kuikenvlees met een hoger niveau van duurzaamheid } \\
\text { (vooral dierenwelzijn en voedselveiligheid), mogelijk ook } \\
\text { smaak daarin meenemen, (Het versterken van het imago } \\
\text { van bijvoorbeeld de } 1 \text { ster beter leven kip, de nieuwe } \\
\text { standaardkip etc.) } \\
\text { - Kansen voor Smart Farming, onder andere betere en } \\
\text { tijdiger signalering van infectieziekten met gebruik van } \\
\text { big data } \\
\text { - Verdere optimalisatie in de keten, verminderen van } \\
\text { faalkosten } \\
\text { Ontwikkelen van een sterk merk voor Nederlands } \\
\text { vleeskuikenvlees }\end{array}$ & 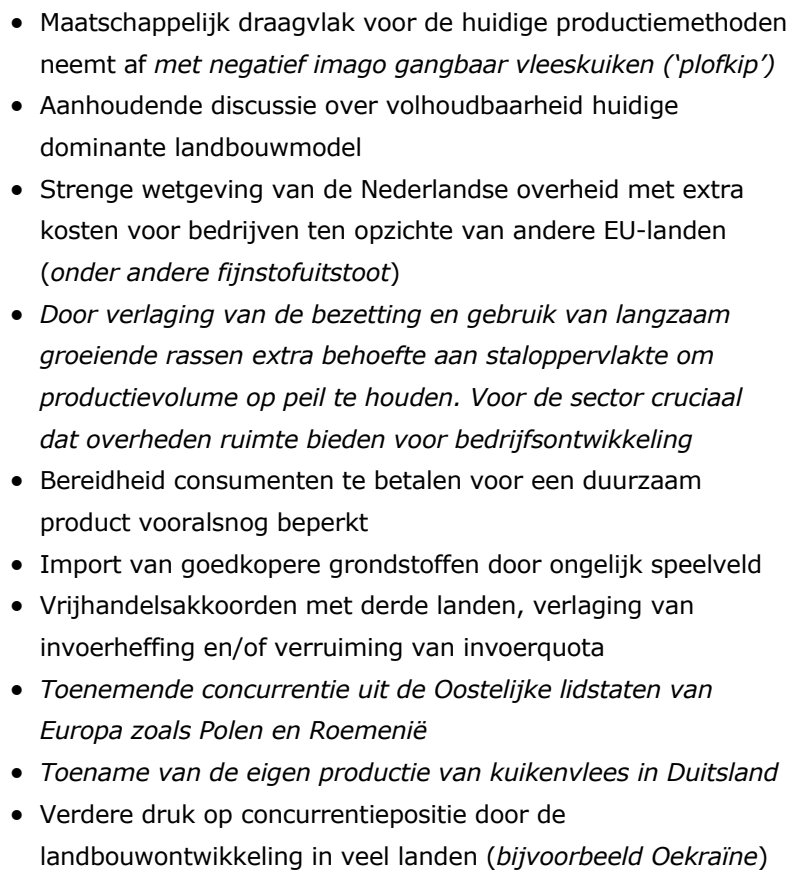 \\
\hline
\end{tabular}

\section{Sterktes}

De Vleeskuikensector kent in Nederland veel sterke internationale toeleverende bedrijven.

De pluimveesector in zijn algemeen kent in Nederland veel sterke Nederlandse toeleverende bedrijven die vooroplopen met de nieuwste stalsystemen, slachterijuitrustingen, broedmachines, efficiënte en/of duurzame voerproductie. Dit komt omdat voornamelijk Nederlandse afnemers van producten hoge eisen stellen aan Nederlandse geproduceerd voedsel. In Nederland is het dan ook goed gesteld met de samenwerking tussen primaire bedrijven en toeleverende bedrijven. (Denk hierbij aan bedrijven die diensten en goederen leveren zoals klimaatspecialisten, mengvoerbedrijven, leveranciers van stalsystemen en farmaceuten etc.). Door goed ondernemerschap, vakmanschap en strenger worden de wet en regelgeving en eisen vanuit de markt wordt innovatie in samenwerking met deze bedrijven telkens tot een hoger niveau gebracht. Doordat Nederland nog altijd moet produceren voor een wereldmarkt worden ondernemers innovatief in het bedenken van essentiële oplossingen om de kostprijs zo ver mogelijk te drukken. 


\section{Zwaktes/kansen}

Nederlands pluimveevlees heeft (nog) geen sterk merk in de markt Nederlandse vleeskuikenshouders moeten aan allerlei kwaliteitssystemen voldoen, deze ketenkwaliteitsystemen zijn vaak strenger dan voor pluimveevlees geproduceerd in een ander bijvoorbeeld niet-Europees land. Dit is een zwakte maar ook een kans om in de toekomst een sterk, integraal merk te ontwikkelen. Het uitbouwen van een sterk Nederlands merk dat de hele vleeskuikenhouderij omvat kan een kans zijn voor de afname van vlees in het buitenland.

\section{Kansen}

Toenemende vraag maatschappij naar duurzamere producten

De consumptie van kip in Nederland neemt geleidelijk verder toe. In de periode 2011-2019 is de consumptie van kuikenvlees toegenomen van 18,4 naar 21,4 kg per hoofd per jaar. Bijna $40 \%$ van de eigen Nederlandse productie van kuikenvlees wordt geëxporteerd. De zelfvoorzieningsgraad is $163 \%$. Zo'n 80-90\% van de export gaat naar EU-landen, met als belangrijkste bestemmingen Duitsland en het Verenigd Koninkrijk. Van de Nederlandse productie wordt een derde afgezet in Nederland (Van Horne, 2020). Afnemers zijn supermarkten (verse kip), foodservice (onder andere restaurants en catering) en de verwerkende bedrijven (kip in verwerkte en samengestelde producten, zoals nuggets en kipsaté). Volgens de Monitor Duurzaam Voedsel was in 2019 het aandeel voor diervriendelijk geproduceerd pluimveevlees $18 \%$ van de bestedingen bij supermarkten. De sterke kanten van de Nederlandse sector zijn een lagere kostprijs, in vergelijking met andere EU-landen, goed georganiseerde slachterijen en een gunstige ligging voor afzet van vers product. Dit biedt vooral mogelijkheden om meer kuikenvlees te exporteren naar het VK en Frankrijk. Het VK is van oudsher een importerend land en kent een grote vraag naar kipfilet. De mogelijkheden op deze markt zijn mede afhankelijk van de ontwikkeling van de wisselkoers euro ten opzichte van het Britse pond.

Door in te spelen op de verschuiving in de markt naar kipdelen zijn er mogelijkheden voor de Nederlandse pluimveevleessector in zowel het gangbare segment als in het tussensegment.

Niet van toepassing

- Stimuleren natuurinclusieve landbouw, zoals Green Deal Natuurincl. landbouw

\section{Bedreigingen}

Import van goedkopere grondstoffen door ongelijk speelveld De VS en Brazilië zijn wereldwijd de belangrijkste exporteurs van pluimveevlees. De kostprijs van kuikenvlees in Brazilië, Argentinië en de VS is duidelijk lager dan in Nederland, vooral door de lage voerprijs. In Brazilië en Argentinië is het klimaat gunstig en zijn de arbeidskosten laag. In de landen buiten de EU wordt de kostprijs verder verlaagd door het ontbreken van met Europa vergelijkbare wet- en regelgeving, waardoor gmo-veevoergrondstoffen, diermeel in diervoeders en groeibevorderaars zijn toegestaan. Door de lagere arbeidskosten zijn de slachtkosten in Brazilië en Argentinië duidelijk lager dan in de EU.

De vleeskuikenbedrijven in Nederland hebben goede productieresultaten en een relatief lage prijs voor voer en eendagskuikens, maar ook hoge mestafzetkosten en hoge kosten voor diergezondheid. Dit leidt tot een relatief hoge kostprijs, deels als gevolg van wet- en regelgeving. De vleeskuikenhouder heeft te maken met Europese en Nederlandse wetgeving op het gebied van dierenwelzijn, voedselveiligheid en milieu. Het gaat dan om extra kosten door mestwetgeving, reductie ammoniakemissie, verbod op gebruik van diermeel, groeibevorderaars en gmo-gewassen, vermindering salmonellabesmettingen en verlaging van de bezettingsdichtheid. Circa twee derde deel van deze kostenposten gelden ook voor de andere EU-landen, omdat de regels gebaseerd zijn op EU-wetgeving. Specifieke Nederlandse kostenposten zijn mestafzet en vermindering van ammoniakemissie en fijnstof. 


\section{(c) Verbeteren van de positie van de landbouwers in de waardeketen;}

SWOT-samenvatting subdoelstelling C Verbeteren van de positie van de landbouwers in de waardeketen

\begin{tabular}{|c|c|}
\hline Sterke punten & Zwakke punten \\
\hline $\begin{array}{l}\text { - Goed ondernemerschap } \\
\text { - Innovatiekracht } \\
\text { - Opkomst korte ketens, ook in de pluimveesector } \\
\text { - Goede samenwerking van ondernemers, } \\
\text { brancheorganisaties en andere ketenpartners zoals } \\
\text { slachterijen, kwaliteitssystemen, en veevoederfabrikanten } \\
\text { - Dichtbij afzetmarkt -als men levert in concepten }\end{array}$ & $\begin{array}{l}\text { - Onderhandelingspositie van primaire bedrijven in de keten } \\
\text { is zwak } \\
\text { - Import van pluimveevlees voldoet aan een andere eisen, } \\
\text { Nederlandse pluimveehouders moeten hiermee } \\
\text { concurreren }\end{array}$ \\
\hline Kansen & Bedreigingen \\
\hline $\begin{array}{l}\text { - Versterking band boer-burger via open stallen, } \\
\text { transparantie } \\
\text { - Belonen van duurzaamheidsprestaties door verwerkers en } \\
\text { consument } \\
\text { - Rol van brancheorganisaties zoals Avined om } \\
\text { - ketensamenwerking te stimuleren } \\
\text { - Rol vleeskuikenhouders in de keten versterken } \\
\text { korte ketens }\end{array}$ & $\begin{array}{l}\text { - Groei van korte ketens/niches kan leiden tot een druk op } \\
\text { de prijs } \\
\text { - Beperkt aandeel in consumenteneuro } \\
\text { - Wet- en regelgeving kan vernieuwende ondernemers } \\
\text { dwarsbomen }\end{array}$ \\
\hline
\end{tabular}

\section{Sterktes}

\section{Goed ondernemerschap/innovatiekracht}

De gemiddelde Nederlandse agrarisch ondernemer toont goed ondernemerschap. Ook Nederlandse pluimveehouders zijn bereid om te investeren en bedrijfsrisico's te nemen. Ook is de innovatiekracht van de sector ten opzichte van andere (landbouw)sectoren hoog. Dit komt mede door de sterke samenwerking van primaire en toeleverende bedrijven. In combinatie met goed ondernemerschap van veehouders (die durven te investeren) zorgt dit voor een gezonde, toekomstbestendige sector die een wendbare kracht heeft om te innoveren.

\section{Niet van toepassing}

- Groei multifunctionele landbouw, met Boer-burger contact

\section{Zwaktes}

Import van pluimveevlees voldoet aan een andere eisen, Nederlandse pluimveehouders moeten hiermee concurreren.

Nederlandse pluimveehouders moeten voldoen aan eisen van de vastgestelde kwaliteitssystemen. Deze zijn vaak strenger ten opzichte van de kwaliteitssystemen/geen kwaliteitssystemen die pluimveehouders in het buitenland hebben. Toch leveren Nederlandse vleeskuikenshouders hun pluimveevlees af op dezelfde markt, Nederlandse pluimveehouders die voldoen aan strengere eisen moeten dus concurreren met buitenlandse pluimveehouders die aan minder strenge eisen onderworpen zijn.

\section{Kansen}

Belonen van duurzaamheidsprestaties door verwerkers en consument.

Om een slag te slaan op het gebied van duurzaamheid zou er meer onderzoek moeten komen naar het verdienmodel en het stimuleren van duurzaamheid in de keten, de prestaties zouden hierna door verwerkers en de consument kunnen worden beloond. 


\section{Bedreigingen}

Groei van korte ketens/niches kan leiden tot een druk op de prijs.

Ketens en niche markten groeien, dit gebeurt ook in de vleeskuikenhouderij. Toch is het noodzaak om vraag en aanbod goed op elkaar af te stemmen. Op het moment dat er voldoende vraag is naar een product zal dit ook worden uitbetaald in een correcte prijs. Op het moment dat er veel aanbod is maar geen vraag wordt er teveel geproduceerd, en is geen correcte prijs mogelijk omdat er geen/weinig afnemers zijn die dit willen betalen. Dit is een reëel probleem bij bijvoorbeeld biologisch pluimveevlees, waar de afzetmarkt vooralsnog beperkt is. Betere afstemming van vraag en aanbod zou hier in kunnen helpen, maar is in de praktijk niet goed haalbaar. 


\section{(d) Bijdragen tot matiging van en aanpassing aan klimaatverandering en tot duurzame energie;}

SWOT-samenvatting subdoelstelling D Bijdragen aan mitigatie en adaptatie aan klimaatverandering en leveren van een bijdrage aan een duurzame energieproductie

\begin{tabular}{|c|c|}
\hline Sterke punten & Zwakke punten \\
\hline $\begin{array}{l}\text { - Pluimveevlees heeft een relatief lage uitstoot van } \\
\text { broeikasgassen, in vergelijking met andere vleessoorten } \\
\text { - Kennis om te innoveren in nieuwe concepten, nieuwe } \\
\text { stalsystemen en nieuwe verdienmodellen. (dit geldt voor } \\
\text { alle sectoren) }\end{array}$ & $\begin{array}{l}\text { - Goedkope fossiele brandstoffen vertragen transitie } \\
\text { - Toepassing van wind- en zonne-energie is nog afhankelijk } \\
\text { van subsidies } \\
\text { - Uitstoot broeikasgassen door vleesproductie is relatief hoog } \\
\text { in vergelijking met plantaardige eiwitbronnen } \\
\text { - Belemmeringen door afval- en mestwetgeving staan } \\
\text { hergebruik van stoffen in de weg (bijvoorbeeld hergebruik } \\
\text { van diermeel) }\end{array}$ \\
\hline Kansen & Bedreigingen \\
\hline $\begin{array}{l}\text { - Kansen om } \mathrm{CO}_{2} \text {-voetafdruk verder te verlagen door } \\
\text { reststromen, zonnepanelen op stallen, warmte uitstoot } \\
\text { kooppelen aan verbruik huishoudens, andere inrichting } \\
\text { van bedrijven/stallen voor verkoeling etc. } \\
\text { - (Onderzoek naar) Nieuwe en innovatieve } \\
\text { bedrijfssystemen } \\
\text { - Energieleverende pluimveehouderij door } \\
\text { energiebesparing, groene energieproductie (zon, wind, } \\
\text { biogas), terugwinnen en hergebruik van warmte } \\
\text { - Energiebesparing en energievergroening in alle } \\
\text { ketenschakels } \\
\text { - Verminderen van de emissies(methaan en ammoniak) uit } \\
\text { mestopslag en mestverwerkingssystemen } \\
\text { fokkerij, en optimale diergezondheid } \\
\text { Doorgaande klimaatverandering (aanzienlijk minder } \\
\text { aardgasgebruik) }\end{array}$ & $\begin{array}{l}\text { - Business as usual in beleid en praktijk, nog geen groot } \\
\text { gevoel van urgentie } \\
\text { - Toenemende concurrentie om de grond } \\
\text { (ruimteclaims) (beperkt de kleine kringlopen) } \\
\text { - Doorgaande klimaatverandering } \\
\text { - Voldoende financieringsmogelijkheden (banken/overheid) } \\
\text { om te investeren in duurzame en toekomstbestendigere } \\
\text { bedrijfssystemen }\end{array}$ \\
\hline
\end{tabular}

\section{Sterktes}

Pluimveevlees heeft een relatief lage uitstoot van broeikasgassen, in vergelijking met andere vleessoorten. Tussen 1990 en 2017 is de $\mathrm{CO}_{2}$-uitstoot bij de productie van kippenvlees (af slachterij) met $46 \%$ afgenomen. Dit was vooral het gevolg van verbetering van voerefficiëntie. Daarnaast zorgt energiebesparing in stallen en opwekking van energie uit mestverbranding voor een verlaging van de $\mathrm{CO}_{2}$ - voetafdruk (figuur 1.) Bijna de helft van de vleeskuikenbedrijven wekt energie op en heeft zonnepanelen op het dak. Ten opzichte van andere vleessectoren heeft de pluimveehouderij een lage uitstoot.

\section{Zwaktes}

Niet van toepassing

- Teelt biomassa kan niet concurreren met teelt akkerbouwgewassen

\section{Kansen}

De ontwikkelingen van nieuwe stalsystemen met brongerichte emissiebeperkende maatregelen in bestaande en nieuwe stallen is essentieel. Hierbij wordt in de komende jaren toegewerkt naar het verder reduceren van de uitstoot van milieubelastende stoffen zoals ammoniak, broeikasgassen, geur en fijnstof. Er worden nieuwe stalconcepten ontwikkeld, die passen bij een diervriendelijke houderij, bij wensen van de markt en consument, die invulling geven aan brandveiligheid, met robuuste en gezonde dieren en die een bijdrage leveren aan het behalen van milieu- en klimaatdoelen en de circulaire economie. 


\section{Bedreigingen}

Niet van toepassing

Verzilting van het grond- en oppervlaktewater 


\section{(e) Bevorderen van duurzame ontwikkeling en efficiënt beheer van natuurlijke hulpbronnen zoals water, bodem en lucht;}

SWOT-samenvatting subdoelstelling E Bevorderen van duurzame ontwikkeling en efficiënt beheer van natuurlijke hulpbronnen, zoals water, bodem en lucht

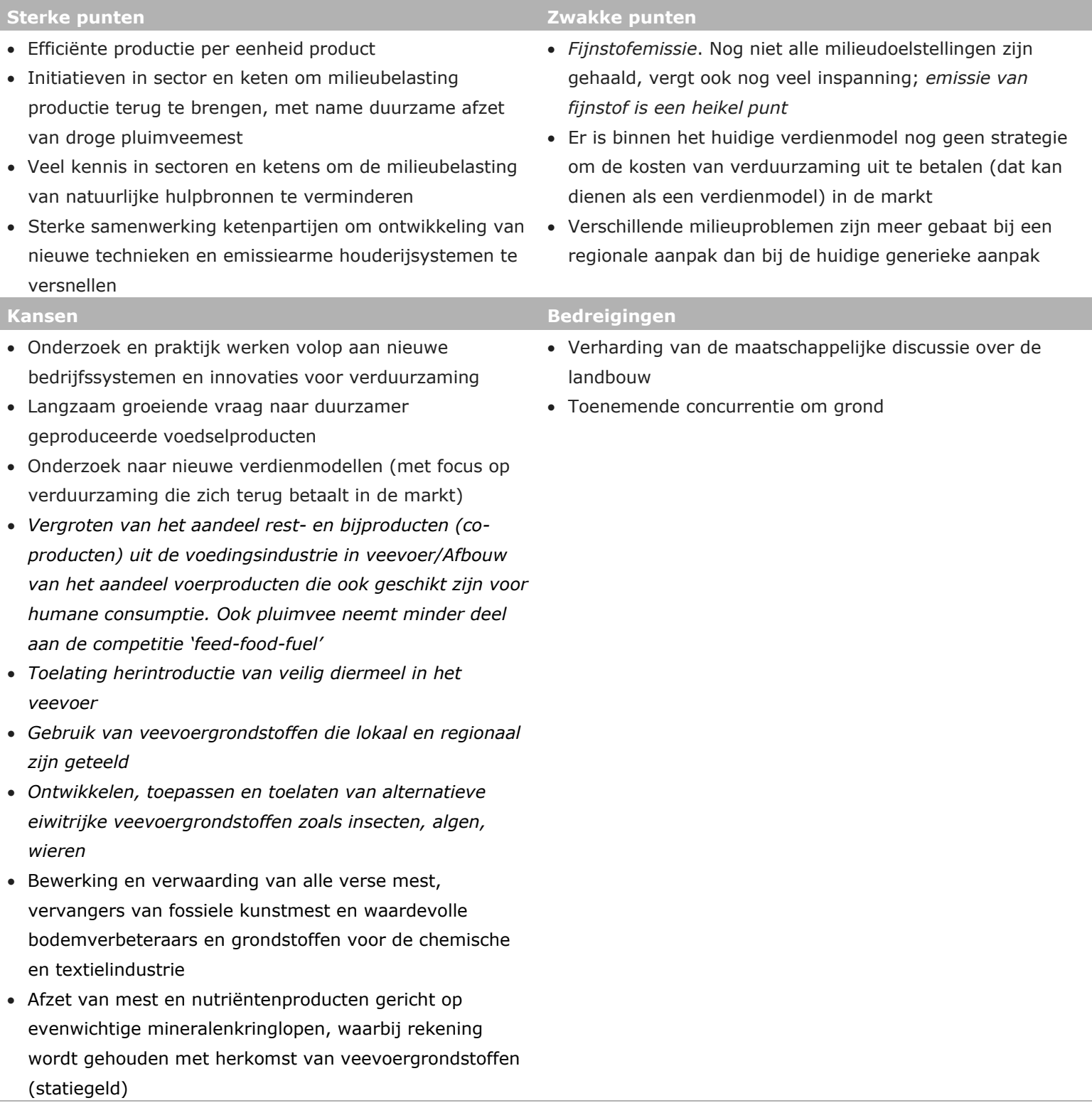

\section{Sterktes}

\section{Niet van toepassing}

- Milieudruk grond en oppervlaktewater met gewasbeschermingsmiddelen, stikstof en fosfaat is stabiel tot afgenomen.

\section{Zwakte}

\section{Stikstofemissie en Fijnstofemissie}

Van de fijnstofemissie (PM10) in Nederland is $21 \%$ in 2018 afkomstig uit de land- en tuinbouw, en daarvan is $65 \%$ afkomstig uit de pluimveehouderij. De laatste jaren is er een daling in de fijnstofemissie, ook in de pluimveesector, onder andere door investeringen in technieken om de uitstoot te verminderen.

De overheid komt met nieuwe doelstellingen voor de reductie van fijnstof, dit is een uitdaging voor de sector om hieraan te voldoen. 
Ook zijn er reductiedoelstellingen voor de stikstofuitstoot. Voor de sector is het een uitdaging om hieraan te voldoen. De pluimveesector heeft haar aandeel in de ammoniakreductie uit het convenant dat in 2014 werd gesloten gehaald, hiervoor is echter niet beloond, sectorleden maken zich zorgen om de haalbaarheid en betaalbaarheid van deze reductiedoelstellingen.

\section{Kansen}

Vergroten van het aandeel rest- en bijproducten (co-producten) uit de voedingsindustrie in veevoer. Afbouw van het aandeel voerproducten die ook geschikt zijn voor humane consumptie. Ook pluimvee neemt minder deel aan de competitie 'feed-food-fuel'.

Toelating herintroductie van veilig diermeel in het veevoer.

Gebruik van veevoergrondstoffen die lokaal en regionaal zijn geteeld.

Ontwikkelen, toepassen en toelaten van alternatieve eiwitrijke veevoergrondstoffen zoals insecten, algen, wieren.

\section{Bedreigingen}

Niet van toepassing

- Verzilting en verslemping groeiend probleem

- Waterbeheer een grotere uitdaging als gevolg meer droge jaren en meer piekbelasting. 


\section{(f) Bijdragen tot de bescherming van de biodiversiteit, versterken van ecosysteemdiensten en in stand houden van Habitats en landschappen.}

Sterke punten

- De diversiteit van het Nederlandse landschap door de ligging in een vruchtbare delta, de variatie in grondsoorten en de ontginningsgeschiedenis

- Ontwikkelingen in de keten om biodiversiteit in de landbouw te belonen

\section{Zwakke punten}

- De zeer zorgelijke toestand van biodiversiteit, ecosysteemdiensten en landschappen in het landelijk gebied en het vooralsnog ontbreken van een positieve trend

- Biodiversiteit maakt vrijwel geen deel uit van de agrarische bedrijfsvoering, inspanningen voor de versterking van biodiversiteit worden veelal onvoldoende beloond

- Het betalen voor biodiversiteit door de markt en de consument is nog geen gemeengoed

\section{Kansen}

- Groeiende maatschappelijke en politieke aandacht voor belang biodiversiteit (zoals onder andere tot uiting komt in het Deltaplan Biodiversiteitsherstel)

- Innovatievermogen door combinatie van kennis en expertise in de agri-food sector, met kennis van ecologie en biodiversiteit

\section{Bedreigingen}

- Industrialisering, verstedelijking en toename infrastructuur

- Klimaatverandering

- Streven van de overheid om zones van extensieve landbouw rondom Natura 2000-gebieden te ontwikkelen

- Ontbreken van integraal beleid voor bodem, mest, klimaat, biodiversiteit en landschap

De vleeskuikensector heeft nauwelijks mogelijkheden om een bijdrage te leveren aan bescherming van de biodiversiteit in Nederland. Wel kan het gebruik van duurzaam geproduceerde veevoergrondstoffen helpen bij het in stand houden van de biodiversiteit in de landen waar deze grondstoffen geproduceerd worden (zie ook opmerkingen hierover bij doelstelling $f$ varkenshouderij). 


\subsection{Referenties}

Agrimatie.nl. Wageningen Economic Research.

Berkhout, Petra Jakob Jager en Bert Smit (2019). Inkomenseffecten van de GLB-aanpassingen per 2020; Een quick scan. Wageningen, Wageningen Economic Research, Rapport 2019-114.

Horne, PLM van (2020). Pluimveevleessector in Nederland; Feiten en cijfers rondom pluimveevlees. Factsheet Wageningen Economic Research.

Horne, PLM van (2013). Concurrentiekracht van de Nederlandse pluimveevleessector. LEI-rapport 2013- 037. ISBN/EAN: 978-90-8615-635-1.

Logatcheva, K. (2019) Monitor Duurzaam Voedsel. Wageningen Economic Research.

Peet, G. van der, Leenstra, F., Vermeij, I., Bondt, N., Puister, L., \& van Os, J. (2018). Feiten en cijfers over de Nederlandse veehouderijsectoren 2018. Wageningen, Wageningen Livestock Research, rapport 1134. https://doi.org/10.18174/464128

Stichting Fonds voor Pluimveebelangen (2008). Toekomstvisie Pluimveehouderij 2015-2020.

https://edepot.wur.nl/169406 


\subsection{Bijlage Indicatoren}

N.B. Alle data zijn op basis van Eurostat of nationale data als in Eurostaat geen gegevens beschikbaar waren op deelsectorniveau.

Indicatoren C.12 tot en met C.34

Tabel C.12 Aantal bedrijven naar bedrijfsgrootte en in ha en standaardopbrengst

\begin{tabular}{lrrr} 
& \multicolumn{3}{c}{ Vleeskuikenbedrijven } \\
\cline { 2 - 4 } Aantal bedrijven naar omvang in ha & 2010 & 2015 & 2020 \\
\hline$<1$ ha & & & \\
\hline $1-5$ ha & 144 & 163 & 221 \\
\hline $5-10$ ha & 83 & 78 & 91 \\
\hline $10-30$ ha & 45 & 35 & 42 \\
\hline $30-50$ ha & 88 & 77 & 61 \\
\hline Totaal & 35 & 36 & 34 \\
\hline
\end{tabular}

Aantal bedrijven naar omvang in standaardopbrengst (SO)

SO: $3.000-25.000$ euro

SO: $25.000-100.000$ euro

SO: $100.000-250.000$ euro

110

SO: $250.000-500.000$ euro

SO: $500.000-1.000 .000$ euro

7

22

52

131

161

SO: $1.000 .000-1.500 .000$ euro

97

SO: $1.500 .000-3.000 .000$ euro

SO: $>3.000 .000$ euro

12

Totaal

469

98

126

126
27

463

Tabel C.13a Arbeidsinzet - in arbeidsjaareenheden

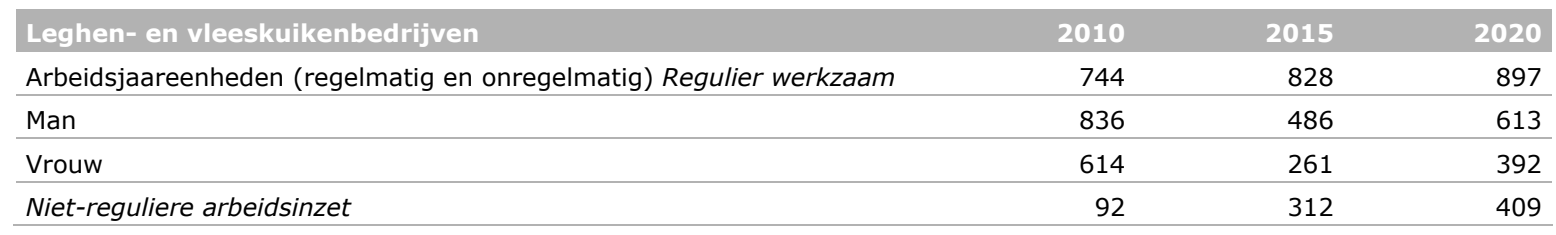

Tabel C.13b Arbeidsinzet: aantal arbeidsjaareenheden naar gezinsarbeid en vreemde arbeid

\begin{tabular}{lrrr} 
Leghen- en vleeskuikenbedrijven & 2010 & 2015 & 2020 \\
gezin & 744 & 763 & 837 \\
\hline Niet-gezin & 161 & 254 & 351 \\
\hline
\end{tabular}

Tabel C.14 Leeftijdsopbouw agrarische bedrijfshoofden

\begin{tabular}{lrrr} 
Vleeskuiken bedrijven & 2010 & 2015 & 2020 \\
$<40$ jaar (A) & 64 & 40 & 55 \\
\hline$>55$ jaar (B) & 276 & 258 & 214 \\
\hline Totaal & 470 & 464 & 507 \\
\hline ratio (A/B) & 23 & 16 & 26 \\
\hline
\end{tabular}

Source: Dutch Farm Structure 
Tabel C.16 Bedrijfsopvolging

\begin{tabular}{|c|c|c|c|}
\hline Vleeskuikenbedrijven & 2012 & 2016 & 2020 \\
\hline aantal bedrijven met een opvolger & 75 & 106 & 118 \\
\hline aantal bedrijven met een bedrijfshoofd $>51$ jaar & 172 & 221 & 267 \\
\hline aandeel bedrijven met een opvolger & 44 & 48 & 44 \\
\hline
\end{tabular}

Tabel C.17 Areaal vleeskuikenbedrijven

\begin{tabular}{lrrr} 
& & 2015 & 2010 \\
Akkerbouwland & 7.434 & 6.966 & 5.623 \\
\hline Blijvend grasland & 1.650 & 1.306 & 1.394 \\
\hline Blijvende teelten & 10 & 33 & 48 \\
\hline Overig & 854 & 1.039 & 9.344 \\
\hline Totaal & 9.499 & 7.921 \\
\hline
\end{tabular}

C18-C23: niet beschikbaar

Tabel C.24 Netto toegevoegde waarde per aje (in euro)

\begin{tabular}{lrrrrrr} 
& 2010 & 2012 & 2014 & 2016 & 2018 & 2019 \\
Vleeskuikenbedrijven (in euro) & 76.089 & 81.676 & 122.657 & 136.780 & 112.884 & 121.596 \\
\hline index & 100 & 107 & 161 & 180 & 148 & 160 \\
\hline
\end{tabular}

Tabel C.25 Inkomen uit bedrijf per oaje (in euro)

\begin{tabular}{lrrrrrr} 
& 2010 & 2012 & 2014 & 2016 & 2018 & 2019 \\
Vleeskuikenbedrijven (in euro) & 30.979 & 37.836 & 98.933 & 124.786 & 109.442 & 83.717 \\
\hline index & 100 & 122 & 319 & 403 & 353 & 270 \\
\hline
\end{tabular}

\section{C.26 niet beschikbaar}

C.27 niet beschikbaar

C.28 niet beschikbaar

C.29 niet beschikbaar

C.30 Niet beschikbaar

C.31 Niet beschikbaar

Tabel C.32 Areaal biologische landbouw en aandeel areaal biologische landbouw op totale areaal landbouwgrond bij leghen- en vleeskuikenbedrijven

\begin{tabular}{|c|c|c|c|c|c|c|}
\hline Leghen- en vleeskuikenbedrijven & 2015 & 2016 & 2017 & 2018 & 2019 & 2020 \\
\hline \multicolumn{7}{|l|}{ Aantal hectares } \\
\hline Totaal areaal biologisch plus in omschakeling & 77 & 88 & 254 & 331 & 367 & 468 \\
\hline Areaal in omschakeling & 39 & 55 & 182 & 183 & 221 & 244 \\
\hline Totaal areaal & 10.305 & 8.979 & 7.463 & 8.783 & 8.595 & 9.157 \\
\hline Areaal biologisch & 0,4 & 0,4 & 1,0 & 1,7 & 1,7 & 2,5 \\
\hline Areaal in omschakeling & 0,4 & 0,6 & 2,4 & 2,1 & 2,6 & 2,7 \\
\hline Totaal areaal & 100 & 100 & 100 & 100 & 100 & 100 \\
\hline
\end{tabular}


Tabel C.33 Intensieve landbouw, aandeel areaal met een hoge inputintensiteit (grond met een totale input van veevoer, kunstmest en gewasbeschermingsmiddelen van meer dan $€ 350$ per ha)

$\begin{array}{lrrr}\text { Aandeel } & 2010 & 2015 & 2019 \\ \text { vleeskuikenbedrijven } & 27 & 67 & 55\end{array}$

C.34 niet beschikbaar.

\section{Indicatoren C.35-C.48}

C.35 niet beschikbaar naar type bedrijf

C.36 niet beschikbaar naar type bedrijf

C.38 niet beschikbaar naar type bedrijf

C.40 niet beschikbaar naar type bedrijf

C.41 niet beschikbaar naar type bedrijf

C.42 niet beschikbaar naar type bedrijf

C.43 niet beschikbaar naar type bedrijf

C.44 niet beschikbaar naar type bedrijf

C.45 niet beschikbaar naar type bedrijf

Tabel C.46 Ammoniakemissies (1.000 ton NH3)

\begin{tabular}{lrrr} 
Vleeskuikenbedrijven & 2010 & 2015 & 2018 \\
Emissies $\mathrm{NH}_{3}$ (1.000 ton) & 4 & 2 \\
\hline Source: Agrimatie/Emissieregistratie. & & 1
\end{tabular}

C. 47 niet beschikbaar naar type bedrijf

Tabel C.48 Afzet van pesticiden (1.000 ton werkzame stof)

\begin{tabular}{rrrr} 
& 2010 & 2015 & 2019 \\
Vleeskuikenhouderij & 0,07 & 0,05 & 0,02 \\
\hline
\end{tabular}


Wageningen Economic Research Postbus 29703

2502 LS Den Haag

T 0703358330

E communications.ssg@wur.nl

www.wur.nl/economic-research

Wageningen Economic Research RAPPORT

2021-075
De missie van Wageningen University \& Research is 'To explore the potential of nature to improve the quality of life'. Binnen Wageningen University \& Research bundelen Wageningen University en gespecialiseerde onderzoeksinstituten van Stichting Wageningen Research hun krachten om bij te dragen aan de oplossing van belangrijke vragen in het domein van gezonde voeding en leefomgeving. Met ongeveer 30 vestigingen, 6.800 medewerkers ( $6.000 \mathrm{fte}$ ) en 12.900 studenten behoort Wageningen University \& Research wereldwijd tot de aansprekende kennisinstellingen binnen haar domein. De integrale benadering van de vraagstukken en de samenwerking tussen verschillende disciplines vormen het hart van de unieke Wageningen aanpak. 



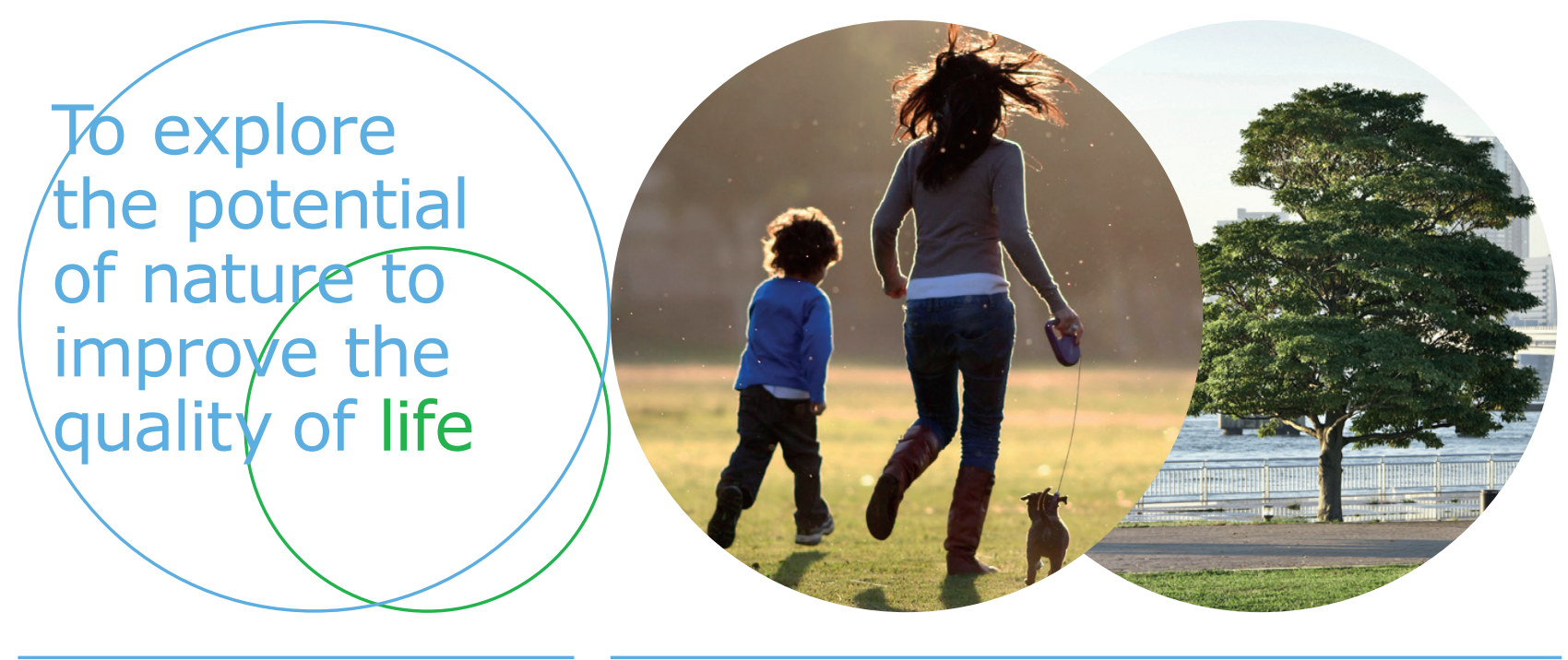

Wageningen Economic Research Postbus 29703

2502 LS Den Haag

T 0703358330

E communications.ssg@wur.nl www.wur.nl/economic-research

Rapport 2021-075

ISBN XXXX
De missie van Wageningen University \& Research is 'To explore the potential of nature to improve the quality of life'. Binnen Wageningen University \& Research bundelen Wageningen University en gespecialiseerde onderzoeksinstituten van Stichting Wageningen Research hun krachten om bij te dragen aan de oplossing van belangrijke vragen in het domein van gezonde voeding en leefomgeving. Met ongeveer 30 vestigingen, 6.800 medewerkers (6.000 fte) en 12.900 studenten behoort Wageningen University \& Research wereldwijd tot de aansprekende kennisinstellingen binnen haar domein. De integrale benadering van de vraagstukken en de samenwerking tussen verschillende disciplines vormen het hart van de unieke Wageningen aanpak. 